Florida International University

FIU Digital Commons

FIU Electronic Theses and Dissertations

University Graduate School

3-30-2018

\title{
Diatoms as tools for inferring changing environmental gradients in coastal, freshwater wetlands threatened by saltwater intrusion
}

\author{
Viviana Mazzei \\ Department of Biological Sciences and Southeast Environmental Research Center, Florida International University, \\ vmazz001@fiu.edu
}

DOI: 10.25148 /etd.FIDC004084

Follow this and additional works at: https://digitalcommons.fiu.edu/etd

Part of the Biology Commons

\section{Recommended Citation}

Mazzei, Viviana, "Diatoms as tools for inferring changing environmental gradients in coastal, freshwater wetlands threatened by saltwater intrusion" (2018). FIU Electronic Theses and Dissertations. 3716.

https://digitalcommons.fiu.edu/etd/3716 


\section{FLORIDA INTERNATIONAL UNIVERSITY \\ Miami, Florida}

\section{DIATOMS AS TOOLS FOR INFERRING CHANGING ENVIRONMENTAL GRADIENTS IN COASTAL, FRESHWATER WETLANDS THREATENED BY SALTWATER INTRUSION}

A dissertation submitted in partial fulfillment

of the requirements for the degree of

DOCTOR OF PHILOSPHY

in

BIOLOGY

by

Viviana Mazzei

2018 
To: Dean Michael R. Heithaus

College of Arts, Sciences, and Education

This dissertation written by Viviana Mazzei and entitled Diatoms as Tools for Inferring Changing Environmental Gradients in Coastal, Freshwater Wetlands Threatened by Saltwater Intrusion, having been approved in respect to style and intellectual content, is referred to you for judgement.

We have read this dissertation and recommend that it be approved.

$\begin{array}{r}\hline \text { Ken Feeley } \\ \hline \text { John Kominoski } \\ \hline \text { Jennifer Richards } \\ \hline \text { Michael Ross } \\ \hline \text { Evelyn Gaiser, Major Professor }\end{array}$

Date of Defense: March 30, 2018

The dissertation of Viviana Mazzei is approved.

Dean Michael R. Heithaus

College of Arts, Sciences, and Education

Andrés G. Gil

Vice President for Research and Economic Development

and Dean of the University Graduate School

Florida International University, 2018 
(C) Copyright 2018 by Viviana Mazzei

All rights reserved. 


\section{DEDICATION}

I dedicate this dissertation in loving memory of my mother. 


\section{ACKNOWLEDGMENTS}

I wish to thank my major professor, Evelyn Gaiser, and committee members, Ken Feeley, John Kominoski, Jennifer Richards, and Mike Ross, for their invaluable support and guidance throughout my time as a doctoral student at Florida international University. I also wish to thank all the amazing people I've had the pleasure of working alongside at the Periphyton Lab with a special thanks to Franco Tobias who showed me the ropes when I was new and continued to be of invaluable help with lab work and species identifications to the end. Last but not least, I thank all the funding agency that have made this work possible: The National Science Foundation through the Florida Coastal Everglades LongTerm Ecological Research program under Cooperative Agreements DEB-1237517, DBI0620409, and DEB-9910514; Florida Sea Grant R/C-S-56, including cooperative agreements with the South Florida Water Management District, the Everglades Foundation, and Everglades National Park; the Everglades Foundation for awarding me the ForEverglades Fellowship; and Florida International University for awarding me the Dissertation Year Fellowship. 


\author{
ABSTRACT OF THE DISSERTATION \\ SALTWATER INTRUSION \\ by \\ Viviana Mazzei \\ Florida International University \\ Miami, Florida \\ Professor Evelyn Gaiser, Major Professor
}

DIATOMS AS TOOLS FOR INFERRING CHANGING ENVIRONMENTAL GRADIENTS IN COASTAL, FRESHWATER WETLANDS THREATENED BY

Saltwater intrusion alters the natural salinity and phosphorus $(\mathrm{P})$ gradients in the oligotrophic, freshwater wetlands located near coastlines of the Caribbean Basin with important consequences to the structure and function of key ecosystem components, including plants, soil microbes, and periphyton. Periphyton communities, particularly diatoms, are extremely sensitive to water quality changes and can serve as excellent bioindicators; however, little is known about their use in detecting novel rates of saltwater intrusion into coastal, freshwater wetlands. I examined the individual and combined effects of elevated salinity and $\mathrm{P}$ on periphyton functional processes and diatom composition by conducting transect surveys along salinity and $\mathrm{P}$ gradients in the southern Everglades, as well as through mesocosm studies in which salinity and P were experimental manipulated. I demonstrated that conductivity (a proxy for salinity) and $\mathrm{P}$ gradients drive spatial patterns in diatom assemblage structure in the southern Everglades and that these assemblages have relatively low conductivity $\left(2 \mathrm{mS} \mathrm{cm}^{-1}\right)$ and total $\mathrm{P}$ thresholds $\left(82 \mu \mathrm{g} \mathrm{g}^{-1}\right)$. These findings were supported by the experimental work which 
showed that monthly pulses of elevated salinity only $\sim 1$ ppt above ambient was sufficient to cause significant shifts in periphytic diatom assemblages along with reduced periphyton productivity, total carbon, and nutrient content. The addition of $\mathrm{P}$ to freshwater and salt-treated periphyton significantly elevated mat total $\mathrm{P}$, underscoring the P-uptake efficiency of periphyton. Surprisingly, addition of $\mathrm{P}$ to freshwater periphyton did not elicit significant functional or compositional responses, although chlorophyll- $a$ concentrations and accumulation rates tended to be higher with P. Similar chlorophyll- $a$ trends were observed for salt-treated mats with added $\mathrm{P}$, but these mats also exhibited significantly higher gross primary productivity and net ecosystem productivity compared to all other treatments and a diatom assemblage distinct from any other treatment. This research provides new and valuable information regarding periphyton dynamics in response to changing water sources that will allow us to extend the use of periphyton, and their diatom assemblages, as tools for environmental assessments related to saltwater intrusion in the southern Everglades and other karstic, freshwater wetlands. 


\section{TABLE OF CONTENTS}

CHAPTER

PAGE

I. GENERAL INTRODUCTION ...........................................

II. DIATOMS AS TOOLS FOR INFERRING ECOTONE BOUNDARIES IN A COASTAL FRESHWATER WETLAND THREATENED BY SALTWATER INTRUSION ..............................................

III. FUNCTIONAL AND COMPOSITIONAL RESPONSES OF PERIPHYTON MATS TO SIMULATED SALTWATER INTRUSION IN THE SOUTHERN EVERGLADES.......................................52

IV. FUNCTIONAL AND COMPOSITIONAL RESPONSES OF PERIPHYTON MATS TO INDIVIDUAL AND SYNERGISTIC EFFECTS OF EXPERIMENTALLY ELEVATED SALINITY AND PHOSPHORUS

V. SCALE AND SPATIAL CONSISTENCY OF SPECIALIZATION IN AN ENDEMIC AND ABUNDANT FRESHWATER DIATOM FROM THE CARIBBEAN BASIN

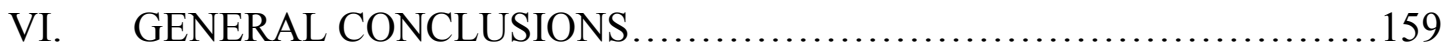

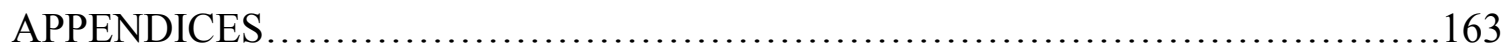

VITA 167 


\section{LIST OF TABLES}

TABLE

PAGE

2-1 Species list including authority, taxon codes, and Threshold Indicator Taxa Analysis derived environmental change points $(\mathrm{CP})$, indicator values (IndVal), and response direction (declining $=\mathrm{z}-$; increasing $=\mathrm{z}^{+}$) for porewater conductivity in the dry, wet, and overall (both seasons combined). Sum(z) scores represent assemblage level CP using all taxa and fsum(z) scores are filtered for pure and reliable taxa only. An asterisk next to the Indval denotes pure and reliable indicator taxa $(>0.95)$

2-2 Species list including authority, taxon codes, and Threshold Indicator Taxa Analysis derived environmental change points (CP), indicator values (IndVal), and response direction (declining $=\mathrm{z}-$; increasing $=\mathrm{z}^{+}$) for periphyton total phosphorus in the dry, wet, and overall (both seasons combined). $\operatorname{Sum}(z)$ scores represent assemblage level CP using all taxa and fsum(z) scores are filtered for pure and reliable taxa only. An asterisk next to the Indval denotes pure and reliable indicator taxa $(>0.95)$

3-1 Means and standard deviations (STDEV) for periphyton net ecosystem productivity (NEP), gross primary productivity (GPP), respiration (R), total carbon (TC), total nitrogen (TN), and total phosphorus (TP) averaged across all sampling dates at the freshwater (FW) and brackish (BW) marsh. ANOVA $p$-values indicate the probability that each variable is significantly different between control $(+\mathrm{AMB})$ and treatment $(+\mathrm{SAL})$ plots $(*=p<0.05)$.

3-2 PERMANOVA output table showing significant main effects of treatment, site, and month, and a significant 3-way interaction effect, on diatom species dissimilarity.

3-3 Significance of post-hoc comparisons on the PERMANOVA 3-way interaction term for treatment factor levels (+AMB and + SAL) at each site during each sampling date.

3 - 4 Indicator diatom taxa classified by multi-level pattern analysis (multipatt \{indicspecies\}) for control (+AMB) and treatment (+SAL) conditions at the freshwater (FW) and brackish water $(\mathrm{BW})$ marsh sites with mean relative abundance of each indicator species in each of the four groups....80

4-1 Means and standard deviations of surface water (SW) salinity and total dissolved phosphorus (TDP); chlorophyll- $a$ (Chl- $a$ ), total carbon (TC), total nitrogen (TN), and total phosphorus (TP) content of periphyton plugs; and ash-free dry mass (AFDM) and Chl- $a$ accumulation rates on settlement plates averaged over all sampling dates for each treatment $(\mathrm{F}=$ freshwater, 
$\mathrm{FP}=$ freshwater and phosphorus, $\mathrm{S}=$ saltwater, $\mathrm{SP}=$ saltwater and phosphorus)....115

4-2 Analysis of similarity (ANOSIM) pair-wise comparisons among treatments ( $\mathrm{F}=$ freshwater, $\mathrm{FP}=$ freshwater and phosphorus, $\mathrm{S}=$ saltwater, $\mathrm{SP}=$ saltwater and phosphorus)..........................................................11

4 - 3 Multi-level pattern analysis (multipatt \{indicspecies\}) results listing diatom taxa significantly associated with treatments and treatment combinations ( $\mathrm{F}=$ freshwater, $\mathrm{FP}=$ freshwater and phosphorus, $\mathrm{S}=$ saltwater, $\mathrm{SP}=$ saltwater and phosphorus)

5 - 1 Correlations between Encyonema evergladianum \% relative abundance, total $\mathrm{P}$ (TP), ash-free dry mass (AFDM), \% mineral content, and conductivity for each region given by Pearson correlation coefficients $(*=p<0.05)$

5-2 Results of the multiple linear regressions on Encyonema evergladianum percent relative abundance against total $\mathrm{P}$ (TP), conductivity (cond), ash-free dry mass (AFDM), and \% mineral content for the combined data set and each individual wetland $(*=p<0.1, * *=p<0.05)$

5 - 3 Mean morphometric data for Encyonema evergladianum specimens from the Everglades, Belize, and Yucatan ( $n=35 /$ site $) . \mathrm{SD}=$ standard deviation, $\min =$ minimum, $\max =$ maximum 


\section{LIST OF FIGURES}

FIGURE

PAGE

2 - 1 Map of southeastern Florida showing the location of the 7 transects and their sites. The transitional area between freshwater and coastal wetlands is visible as a white zone in the satellite imagery. Yellow boxes define western and eastern transects.

2-2 Latitudinal porewater conductivity (A) and periphyton total phosphorus (B) gradients at successive points along each transect during the dry and wet seasons averaged over 2014 and 2015 samples. Transects are separated by solid vertical lines and ordered west to east to display longitudinal gradients. The environmental gradient for each transect is plotted on the first y-axis (black lines). Grey dashed lines represent transects with successive sites along each transect on the $\mathrm{x}$-axis and their distance from the coast on the second y-axis.

2 - 3 Principal coordinate analysis (PCO) ordination plots of dry (top) and wet (bottom) seasons, including 2014 and 2015 samples, showing sites grouped based on $45 \%$ species similarity and significantly correlated environmental variables. Symbols represent the transect to which the site belongs and labels denote the distance quartile for the site (NN, N, C, S). The groups were designated as either freshwater, transitional, or brackish water based on the sites that fell within each cluster.

2-4 Principal coordinate analysis (PCO) axis 1 scores for successive sites along each transect during the dry (A) and wet (B) seasons. Transects are separated by solid vertical lines and ordered west to east to display longitudinal differences in the location of the ecotone. PCO axis score for sites along each transect is plotted on the first y-axis (black lines). Grey dashed lines represent transects with successive sites along each transect on the $\mathrm{x}$-axis and their distance from the coast on the second y-axis. The location of the ecotone at each transect, determined as the vector with the greatest slope is represented by grey boxes placed on corresponding points on the transect lines

$2-5$ The magnitude of average porewater conductivity (A) and total phosphorus (B) at each site, averaged over all four sampling events, is represented by the size of the orange and blue circles, respectively. Pie charts show the relative abundances, also averaged over the four sampling events, of pure and reliable indicator taxa for conductivity and TP at each site. The diatom-inferred ecotone identified from principal coordinate analysis axis score plots for the dry (solid line) and wet (dashed line) are drawn on each map. 
2-6 Threshold Indicator Taxa Analysis (TITAN) of periphytic diatom response to porewater (PW) conductivity gradients in the southern Everglades during the dry (A), wet (B), and overall seasons (C). Change points and their distributions $\left(5^{\text {th }}\right.$ and $95^{\text {th }}$ percentiles $)$ of pure and reliable $(>0.95)$ indicator taxa (top). Assemblage-level response to PW conductivity where a peak in filtered $\operatorname{sum}\left(\mathrm{z}^{-}\right)$and $\operatorname{sum}\left(\mathrm{z}^{+}\right)$indicates an assemblage threshold where a coincident decline or increase in taxa occurs (bottom). Solid circles are negative taxa (z-); open circles are positive taxa $\left(\mathrm{z}^{+}\right)$; dotted horizontal lines on the taxa plots represent $5^{\text {th }}$ and $95^{\text {th }}$ percentiles of CPs; dotted vertical lines signify location of assemblage-level threshold. Taxa codes are defined in Table 1

2-7 Threshold Indicator Taxa Analysis (TITAN) of periphytic diatom response to periphyton total phosphorus (TP) gradients in the southern Everglades during the dry (A), wet (B), and overall seasons (C). Change points and their distributions $\left(5^{\text {th }}\right.$ and $95^{\text {th }}$ percentiles) of pure and reliable $(>0.95)$ indicator taxa (top). Assemblage-level response to PW conductivity where a peak in filtered $\operatorname{sum}\left(\mathrm{z}^{-}\right)$and $\operatorname{sum}\left(\mathrm{z}^{+}\right)$indicates an assemblage threshold where a coincident decline or increase in taxa occurs (bottom). Solid circles are negative taxa $\left(\mathrm{z}^{-}\right)$; open circles are positive taxa $\left(\mathrm{z}^{+}\right)$; dotted horizontal lines on the taxa plots represent $5^{\text {th }}$ and $95^{\text {th }}$ percentiles for CPs; dotted vertical lines signify location of assemblage-level threshold. Taxa codes are defined in Table 2

3 - 1 Reference map of Everglades National Park, Florida, USA (A) and the location of freshwater $(\mathrm{FW})$ and brackish $(\mathrm{BW})$ marsh sites within the park (B). Image of the experimental chambers used to enclose a plot of marsh from where samples and environmental measurements were taken $(C)$. Diagram showing the experimental design layout (D). Blue circles represent control (+AMB) chambers and green circles represent the salinity treatment (+SAL) chambers.

3-2 Mean surface water and porewater salinity in control (+AMB) and treatment $(+\mathrm{SAL})$ plots at the freshwater (A) and brackish water (B).

3-3 Periphyton metabolism (net ecosystem productivity, NEP; ecosystem respiration, ER; and gross primary productivity, GPP), periphyton carbon content (total carbon, TC; organic carbon, OC; and inorganic carbon, IC), periphyton total nitrogen (TN), and periphyton total phosphorous (TP) in control (+AMB) and treatment $(+\mathrm{SAL})$ plots at the freshwater $(\mathrm{A})$ and brackish water (B) sites in order from top to bottom. Asterisk represent significant treatment effects within each sampling date.

3-4 Nonmetric multidimensional scaling (NMDS) ordinations (left) and analysis of similarity (ANOSIM) boxplots showing ranked species dissimilarity within 
and between groups (right). Freshwater (FW) and brackish (BW) diatom assemblages were highly dissimilar throughout the experiment (top). Diatom assemblages were significantly different between control (+AMB) and treatment $(+\mathrm{SAL})$ plots at the freshwater (center) and brackish water (bottom) site. Dispersion was greater within the + SAL treatment group compared to the + AMB group for both the FW and BW.

3 - 5 Indicator taxa plates for freshwater $+A M B(A)$, freshwater $+S A L(B)$, brackish water + AMB (C) and brackish water + SAL (D) conditions. Image numbers correspond to taxa number in Table 3

4-1 Layout of the 6 concrete crypts and the housing containers for the 4 sawgrass cores (A) and a close-up of one of the individual housing containers with the sawgrass core and periphyton. Conceptual diagram of the experimental design (C). Rectangles represent individual crypts (white rectangle $=$ fresh crypts; gray rectangle $=$ salinity crypts). Circles represent cores and the letters designate the treatment each core received $(\mathrm{F}=$ freshwater control; $\mathrm{FP}=$ freshwater and phosphorus; $\mathrm{S}=$ salinity; $\mathrm{SP}=$ salinity and phosphorus).

4-2 Monthly mean surface water (SW) salinity (A) and total dissolved phosphorus (TDP) (B) across treatments $(n=6)$

4 - 3 Bi-monthly mean periphyton total phosphorus (TP), total nitrogen (TN), total carbon (TC), and chlorophyll- a (Chl- $a$ ) (column A) across treatments $(n=6)$. Multivariate analysis of variance (MANOVA) estimated marginal means for each variable across treatments (column B).

4-4 Mean periphyton ash-free dry mass (AFDM) and biomass-specific chlorophyll- $a$ (Chl- $a$ ) accumulation rates across treatment for each settlement plate deployment period (column A). Multivariate analysis of variance (MANOVA) estimated marginal means for each variable across treatments (column B).

4-5 Periphyton net ecosystem productivity (NEP), ecosystem respiration (ER), and gross primary productivity (GPP) one time measurements on periphyton plugs collected on February 2016. Lettering indicates significant differences among treatments for each variable based on MANOVA posthoc pair-wise comparisons across treatment groups.

4-6 NMDS ordination of diatom species dissimilarity among treatments $(\mathrm{F}=$ freshwater, $\mathrm{FP}=$ freshwater and phosphorus, $\mathrm{S}=$ saltwater, $\mathrm{SP}=$ saltwater and phosphorus) 
5 - 1 Box-and-whisker plots for Encyonema evergladianum abundance (A), conductivity (B), periphyton total $\mathrm{P}(\mathrm{TP})(\mathrm{C})$, periphyton ash-free dry mass (AFDM) (D), and periphyton mineral content (E) for Belize, Everglades, and Yucatan. Lines in boxes are medians, box ends are quartiles, whiskers are max and min values, circles are outliers, and stars are extreme outliers. Boxes with the same lower case letter are not significantly different ( $p \geq$ $0.05)$

5 - 2 Partial regression plots with confidence intervals of significant predictors of Encyonema evergladianum abundance in Belize (AFDM) (A), Everglades (AFDM) (B) Yucatan (conductivity) (C), and the 3 locations combined $(\mathrm{AFDM})(\mathrm{D}) . \mathrm{AFDM}=$ ash-free dry mass

5-3 Nonmetric multidimensional scaling ordination of morphological data showing specimen groupings by location. $\mathrm{L}: \mathrm{W}=$ length:width ratio

5 - 4 Size declinations of Encyonema evergladianum from Belize (A), Everglades (B), and Yucatan (C). Scale bar $=10 \mu \mathrm{m}$

5 - 5 Photograph of typical calcareous periphyton mat (A), scanning electron micrograph of the internal mat structure (B), Encyonema evergladianum embedded within the mat matrix (C), and scanning electron micrographs of E. evergladianum $($ scale bar $=5 \mu \mathrm{m})(\mathrm{D})$ 


\section{ABBREVIATIONS AND ACRONYMS}

FW - freshwater

BW - brackish water

SW - surface water

PW - porewater

AFDM - ash-free dry mass

$\mathrm{TC}$ - total carbon

$\mathrm{TN}$ - total nitrogen

$\mathrm{TP}$ - total phosphorus

Chl-a - chlorophyll-a

TDP - total dissolved phosphorus

SRP - soluble reactive phosphorus

+AMB - plus source water controls (field mesocosm experiment ch.3)

+SAL - saltwater treatment (field mesocosm experiment ch.3)

$\mathrm{F}$ - freshwater treatment (ex-situ salinity and P experiment ch.4)

FP - freshwater and phosphorus treatment

$\mathrm{S}$ - saltwater treatment

$\mathrm{SP}$ - saltwater and phosphorus treatment 


\section{CHAPTER I}

\section{GENERAL INTRODUCTION}

Environmental gradients play an important role in structuring communities. Species are organized within an ecosystem based on their ability to succeed under different environmental conditions, and form communities based on the degree of niche overlap, dispersal ability, and demographic stochasticity (Tilman 2004). Consequently, species composition and relative abundances are expected to shift along environmental gradients creating clear patterns in the landscape. The species-sorting model is the mechanism most often invoked to explain species assembly patterns along environmental gradients, although more quantitative studies in support of this theory are needed to understand the relative roles of niche-based and neutral processes in driving observed patterns (Leibold et al. 2004, Cottenie 2005, Gucht et al. 2007, Chase and Myers 2011). The species-sorting (i.e. environmental filtering) model hypothesizes that the regional species pool is sorted through abiotic and biotic filters resulting in local communities based on individual environmental tolerance and the effects of abiotic conditions on species interactions. The spatial patterns produced by species-sorting along environmental gradients may result in transitional areas, or ecotones, between adjacent habitat types. Ecotones are defined as transitional areas between distinct ecological habitats and are characterized by rapid species turnover and the presence of species that are at their distributional limits (Walker

et al. 2003, Peters et al. 2006, Attrill and Rundle 2002). These characteristics suggest that community response to changes in the environment will likely be observed in these 
transitional areas first, making ecotones valuable gauges of environmental fluctuations (Wasson et al. 2013).

The Florida Everglades, like other freshwater, karstic wetlands located near coastlines, are severely threatened by saltwater intrusion due to sea level rise and water management outcomes. The effects of saltwater intrusion are exacerbated by the flat, karstic geology of these landscapes which creates extraordinary susceptibility to changing fresh- and marine water supplies. Marine water intrusion not only elevates salinities in the interior marshes (Davis et al. 2005, Saha et al. 2011) but can also increase P availability in these naturally P-limited systems (Price 2006, Briceno et al. 2014). The Florida Everglades is described as an "up-side down" estuary because, unlike most estuaries, P concentrations are higher in coastal wetlands compared to interior freshwater marshes and marine water is the dominant source of P to marshes in the southern Everglades, especially those adjacent to the Gulf of Mexico (Childers et al. 2006). The intrusion of saltwater through the limestone bedrock introduces a second source of $\mathrm{P}$ as saltwater causes $\mathrm{CaCO}_{3}$-bound $\mathrm{P}$ to be desorbed and made biologically available (Price et al. 2006). Therefore, saltwater intrusion is expected to simultaneously alter natural salinity and P gradients in freshwater, karstic wetlands.

The Florida Everglades occurs along a gradient of increasing salinity and P from the inland freshwater marshes to the coast. An ecotone is present between the fresh and brackish water wetlands that, in some regions of the ecosystem, is clearly visible from the air and remote imagery as a "white zone" (Egler 1952, Ross et al. 2000). This zone is characterized by sparse, low stature vegetation and light-colored marl soil that is responsible for the appearance of this area as a white band in aerial and satellite imagery 
(Egler 1952, Ross et al. 2000, Davis et al. 2005). The width and location of freshwater, ecotone, and coastal communities along this gradient have changed markedly over decadal timescales and are expected to continue to transform, potentially rapidly, in response to continued sea level rise and changes in freshwater flows driven by current water management practices and continued restoration efforts (Wanless and Valswinkei 2005). The effects of changes in the freshwater-marine balance are expected to be most pronounced at the ecotone, particularly downstream of restoration projects, making the ecotone a focal area of research to inform coastal resource management. However, successful assessments and mitigation strategies of saltwater intrusion and ecotone migration in the Everglades requires an understanding of how key ecosystem components, including plants, soil microbes, and periphyton, respond to the simultaneous salinity stress and $\mathrm{P}$ subsidies provided by saltwater intrusion.

Calcareous periphyton - microbial assemblages of mat-forming and calcium carbonate precipitating algae and bacteria, is an important and abundant component of these karstic, freshwater wetlands. The characteristic, calcareous periphyton mats of the Everglades, and particularly their diatom assemblages, provide an ideal community to study the patterns and mechanisms of community assembly along environmental gradients with ecotones and monitor changes to these gradients caused by saltwater intrusion. These microbial mats provide a unique microhabitat for a variety of autotrophic and heterotrophic organisms and play an important role in food web dynamics, organic and inorganic carbon cycling, nutrient cycling, and marl soil formation (Gaiser et al. 2011, Hagerthey et al. 2011, La Hee and Gaiser 2012). Understanding the organization of periphytic diatom assemblages along the freshwater-ecotone-coastal gradient in the southern Everglades and 
the mechanisms shaping those patterns is necessary to develop diatom indicators that can be used to document and predict rates of ecotone movement driven by saltwater intrusion and changing freshwater inflows. Diatom-based autecological indices are a trusted and popular tool in ecological assessments given the short generation rates, sensitivity to environmental fluctuations, and relative ease of diatom identification compared to other algae (Stevenson et al. 1999). They also are sentinels of changes in ecosystem properties including dependent food web structure and function (Trexler et al. 2015). Therefore, diatom assemblages represent an enormous untapped potential for tracking the advancement (or retreat) of P-rich marine supplies into freshwater marshes and the associated inland migration of the ecotone with sea level rise.

Successful assessments and mitigation strategies of saltwater intrusion employing periphyton requires an understanding of how this important ecosystem component responds to the simultaneous salinity stress and P subsidies provided by saltwater intrusion. This research had four components: 1) a field survey of periphytic diatom flora along salinity and P gradients; 2) an in-situ mesocosm experiment testing the effects of pulsed salinity exposure on functional and compositional aspects of periphyton mats; 3) an ex-situ experiment looking at the individual and synergistic effects of salinity and phosphorus on periphyton function and species composition; and 4) a study investigating drivers and spatial consistency of specialization in one of the most abundant periphytic diatoms from karstic wetlands in the Caribbean Basin. The experimental studies were intended to provide a mechanistic foundation of field-based discoveries and are part of a larger multidisciplinary project aimed at understanding the processes underlying ecosystem change driven by saltwater intrusion. 


\section{LITERATURE CITED}

Cottenie, K., 2005. Integrating environmental and spatial processes in ecological community dynamics. Ecology letters, 8(11), pp.1175-1182.

Van der Gucht, K., Cottenie, K., Muylaert, K., Vloemans, N., Cousin, S., Declerck, S., Jeppesen, E., Conde-Porcuna, J.M., Schwenk, K., Zwart, G. and Degans, H., 2007. The power of species sorting: local factors drive bacterial community composition over a wide range of spatial scales. Proceedings of the National Academy of Sciences, 104(51), pp.20404-20409.

Leibold, M.A., Holyoak, M., Mouquet, N., Amarasekare, P., Chase, J.M., Hoopes, M.F., Holt, R.D., Shurin, J.B., Law, R., Tilman, D. and Loreau, M., 2004. The metacommunity concept: a framework for multi-scale community ecology. Ecology letters, 7(7), pp.601-613.

Chase, J.M. and Myers, J.A., 2011. Disentangling the importance of ecological niches from stochastic processes across scales. Philosophical transactions of the Royal Society B: Biological sciences, 366(1576), pp.2351-2363.

Tilman, D., 2004. Niche tradeoffs, neutrality, and community structure: a stochastic theory of resource competition, invasion, and community assembly. Proceedings of the National academy of Sciences of the United States of America, 101(30), pp.10854-10861.

Walker, S., Wilson, J.B., Steel, J.B., Rapson, G.L., Smith, B., King, W.M., Cottam, Y.H., 2003. Properties of ecotones: evidence from five ecotones objectively determined from a coastal vegetation gradient. Journal of Vegetation Science, 14: 579-590.

Peters, D.P., C., Gosz, J.R., Pockman, W.T., Small, E.E., Parmenter, R.R., Collins, S.L., Muldavin, E., 2006. Integrating patch and boundary dynamics to understand and predict biotic transitions at multiple scales. Landscape Ecology, 21: 19-33.

Attrill, M.J. \& Rundle, S.D., 2002. Ecotone or ecocline: ecological boundaries in estuaries. Estuarine, Coastal and Shelf Science, 55: 929-936.

Wasson, K., Woolfolk, A., Fresquez, C., 2013. Ecotones as indicators of changing environmental conditions: rapid migration of salt marsh-upland boundaries. Estuaries and Coasts, 36: 654-664.

Davis, S. M., Childers, D. L., Lorenz, J. J., Wanless, H. R., Hopkins, T. E. 2005. A conceptual model of ecological interactions in the mangrove estuaries of the Florida Everglades. Wetlands, 25:832-842. 
Price, R. M., Swart, P. K., Fourqurean, J. W. 2006. Coastal groundwater discharge-an additional source of phosphorus for the oligotrophic wetlands of the Everglades. Hydrobiologia, 569:23-36.

Saha, A.K., Saha, S., Sadle, J., Jiang, J., Ross, M.S., Price, R.M., Sternberg, L.S., Wendelberger, K.S., 2011. Sea level rise and South Florida coastal forests. Climatic Change, 107: 81-108.

Childers, D. L., Boyer, J. N., Davis, S. E., Madden, C. J., Rudnick, D. T., Sklar, F. H. 2006. Relating precipitation and water management to nutrient concentrations in the oligotrophic "upside-down" estuaries of the Florida Everglades. Limnology and Oceanography, 51: 602-616.

Briceño, H., Miller, G., Davis III, S. E. 2014. Relating freshwater flow with estuarine water quality in the Southern Everglades mangrove ecotone. Wetlands, 34:101111.

Egler, F. E. 1952. Southeast saline Everglades vegetation, Florida and its management. Vegetatio, 3: 213-265.

Ross, M.S., Meeder, J.F., Sah, J.P., Ruiz, P.L., Telesnicki, G.J. 2000. The Southeast Saline Everglades revisited: a half-century of coastal vegetation change. Journal of Vegetation Science, 11:101-112

Wanless, H. R. \& Vlaswinkel, B. 2005. Coastal landscape and channel evolution affecting critical habitats at Cape Sable, Everglades National Park, Florida. Final Report to Everglades National Park, United States Department of the Interior, Homestead, FL, USA.

Hagerthey, S. E., Bellinger, B. J., Wheeler, K., Gantar, M., Gaiser, E. 2011. Everglades periphyton: a biogeochemical perspective. Critical Reviews in Environmental Science and Technology, 41:309-343.

Gaiser, E. E., McCormick, P. V., Hagerthey, S. E., Gottlieb, A. D. 2011. Landscape patterns of periphyton in the Florida Everglades. Critical Reviews in Environmental Science and Technology, 41: 92-120.

La Hée, J. M., \& E. E. Gaiser. 2012. Benthic diatom assemblages as indicators of water quality in the Everglades and three tropical karstic wetlands. Freshwater Science, 31:205-221.

Stevenson, R.J., Pan, Y., van Dam, H., 1999. Assessing environmental conditions in rivers and streams with diatoms in The Diatoms: Applications for the Environmental and Earth Sciences, 2nd ed. Cambridge University Press, Cambridge. 
Trexler, J.C., Gaiser, E.E., Kominoski, J.S. and Sanchez, J., 2015. The role of periphyton mats in consumer community structure and function in calcareous wetlands: lessons from the Everglades. Microbiology of the Everglades Ecosystem. Science Publications, CRC Press, Boca Raton, pp.155-179. 


\title{
CHAPTER II
}

DIATOMS AS TOOLS FOR INFERRING ECOTONE BOUNDARIES IN A COASTAL FRESHWATER WETLAND THREATENED BY SALTWATER INTRUSION

\begin{abstract}
Species sorting mechanisms often control community assembly patterns across environmentally heterogeneous landscapes, particularly within microbial communities that respond quickly to environmental variability and are not dispersal-limited on intermediate time scales. In this study, we describe the spatial and seasonal patterns of two key environmental drivers, porewater (PW) conductivity and total phosphorus (TP), in the southern Everglades, FL., USA where saltwater intrusion, caused by rising sea level and hydrologic management, are transforming the natural environmental gradients of this ecological stressor and limiting nutrient. We surveyed diatom assemblages along transects capturing PW conductivity and TP gradients and searched for spatial boundaries in diatom assemblages along each transect. We also determined diatom assemblage thresholds to PW conductivity and TP, and identified significant indicator taxa with either negative (declining) or positive (increasing) relationships to each driver and their individual thresholds. We demonstrate that the southern Everglades exhibits spatially-structured gradients of conductivity and $\mathrm{P}$ that are oriented in two dimensions (i.e., with distance from the coast and from west to east) and are often, but not always, positively correlated. Our results show that these gradients drive spatial patterns of compositional similarity among
\end{abstract}


our sampling sites. We found the location of greatest dissimilarity in diatom assemblages for each transect coincided with the upper boundary of the "white zone" - the visible ecotone between freshwater and coastal marshes. We did not detect seasonal differences in the position of the diatom-inferred ecotone as expected, nor did we detect significant differences in PW conductivity or TP between wet and dry seasons. Diatom assemblages were highly sensitive to both PW conductivity, with freshwater indicator assemblages declining above $2 \mathrm{mS} \mathrm{cm}^{-1}$ and becoming replaced by a brackish water assemblage at around $20 \mathrm{mS} \mathrm{cm}^{-1}$, and periphyton TP, with thresholds at 82 and $285 \mu \mathrm{g} \mathrm{g}^{-1}$ for negativelyand positively responding taxa, respectively. Our study highlights that small increases in PW conductivity and TP are sufficient to cause shifts in the diatom assemblages of the Everglades. As saltwater continues to encroach into this area, compositional changes in this important primary producer assemblage are expected to cascade through the ecosystem and influence the food web. The diatom indicator taxa and assemblage thresholds presented here offer a sensitive tool that should continue to be developed and applied to management strategies for saltwater intrusion while its effects can still be mitigated. 


\section{INTRODUCTION}

The patterns and mechanisms of community assembly are central to ecological theory and have practical applications in employing indicator species to detect and predict environmental change. Environmental gradients are often the strongest structuring force behind community assembly due to species sorting (i.e., environmental filtering), one of the four paradigms of metacommunity theory (along with neutral theory, mass effects, and patch dynamics; Leibold et al. 2004). Although these four mechanisms of metacommunity structure are not mutually exclusive, species sorting is considered to have the strongest influence on community assembly in heterogeneous environments and over spatial scales favoring intermediate dispersal (Heino et al. 2004, Leibold et al. 2004, Chase and Myers 2011). Species-sorting along spatially-structured environmental gradients often produce landscape-scale habitat zonation patterns that may include ecotones - transitional areas between adjacent habitat types that are characterized by rapid species turnover and the presence of species that are at their distributional limits (Walker et al. 2003, Peters et al. 2006, Attrill and Rundle 2002). These characteristics suggest that community response to environmental variability will likely be observed in ecotones first, making them potentially valuable gauges of changing climatic conditions (Wasson et al. 2013).

The Florida Everglades is a coastal, freshwater wetland characterized by a spatiallystructured gradient of increasing salinity and phosphorus (P) from the inland freshwater marshes to the coast. An ecotone is present between the fresh and brackish water wetlands that, in some regions of the ecosystem, is clearly visible from the air and remote imagery as a "white zone". This zone is characterized by sparse vegetation, dominated by "dwarf" red mangroves (Rhizophera mangle), sawgrass (Cladium jamaicense), and spikerush 
(Eleocharis spp.), and light-colored marl soil that is responsible for the appearance of this area as a white band in aerial and satellite imagery (Egler 1952, Ross et al. 2000, Davis et al. 2005). The width and location of this "white zone" ecotone have changed markedly over decadal timescales in response to saltwater intrusion caused by rising sea levels and reduced freshwater flows from upstream (Ross et al. 2000, Davis et al. 2005). Ross et al. (2000) documented the interior migration of the "white zone" by $1.46 \mathrm{~km}$ using a series of aerial photographs from 1940 to 1994 and noted that areas where the "white zone" migrated the furthest were those most deprived of freshwater (i.e., southeastern region). Another study estimated the rate of ecotone transgression elsewhere in the coastal Everglades at 3.1 $\mathrm{m} / \mathrm{yr}$. over the last 70 years using fossil mollusks (Gaiser et al. 2006a).

The effects of saltwater intrusion in the Everglades is exacerbated by the flat, karstic geology of the landscape which creates extraordinary susceptibility to changing freshwater and marine supplies (Ross et al. 2000, Wanless and Valswinkei 2005). Marine water intrusion not only elevates salinities in the interior marshes (Davis et al. 2005, Saha et al. 2011) but can also increase P availability (Price 2006, Briceno et al. 2014). The Florida Everglades is a naturally P-limited system described as "upside down" because it receives most of this limiting nutrient from the sea rather than from land like most estuaries (Childers et al. 2006, Price et al. 2006). In the absence of freshwater restoration, saltwater intrusion continues to cause transgression of the coastal ecotone into the oligotrophic freshwater marshes by modifying environmental conditions to favor coastal communities (Jiang et al. 2012, Troxler et al. 2014). The effects of changes in the freshwater-marine balance are expected to be most pronounced at the ecotone, particularly in areas that are most disconnected from upstream freshwater flow where there is less freshwater to hold 
back intruding marine water. Therefore, the ecotone is an important area to focus research that will inform best management practices with regards to saltwater intrusion for the southern Everglades.

The characteristic, calcareous periphyton mats of the Everglades, and particularly their diatom assemblages, provide an ideal community to study the patterns and mechanisms of community assembly along environmental gradients with ecotones. Understanding these pattern and mechanisms can be incorporated into tools for predicting changes in coastal gradients due to climate change and water management decisions. Periphyton mats are composed of diatoms, cyanobacteria, and chlorophytes embedded in a matrix of mucilage and interstitial calcium carbonate $\left(\mathrm{CaCO}_{3}\right)$ in which bacteria, fungi, and detritus are also incorporated (Hagerthey et al. 2011). The structure and distribution of these mats across the Everglades landscape is being altered through a combination of elevated salinity and P associated with saltwater intrusion. When exposed to elevated P 5 $\mu \mathrm{g} \mathrm{L^{-1 }}$ above background $\left(\sim 5-10 \mu \mathrm{g} \mathrm{L}^{-1}\right)$, periphyton biomass decreases and community composition shifts from endemic to weedy taxa that do not form cohesive $\mathrm{CaCO}_{3}$ mats (McCormick and O'Dell 1996, Gaiser et al. 2006). Changes in solute concentration caused by elevated salinity disturb algal cell physiology and trigger community composition shifts from freshwater to salt-tolerant species that do not form cohesive-calcareous mats (Ross et al., 2002; Gaiser et al. 2004; Frankovich et al. 2006, Wachnicka et al. 2011). Periphyton has been shown to respond more quickly and predictably to these changes in hydrology and water quality than other wetland plant communities because of the environmental specificity and short generation rates of resident taxa (Gaiser 2009). For instance, periphytic diatoms can predict $67 \%$ of the variance in periphyton TP in northern Taylor 
Slough (Gaiser et al. 2006) and 75\% of water column TP in coastal Everglades wetlands (Wachnicka et al. 2010); 97\% of salinity in coastal wetlands (Wachnicka et al. 2010); and $63 \%$ of hydroperiod variance in the Greater Everglades (Lee et al. 2013). Accordingly, periphytic diatoms are used to monitor these variables in assessment studies of those regions (Gaiser et al. 2011) and represent an enormous untapped potential for tracking the advancement (or retreat) of P-rich marine supplies into freshwater marshes and the associated inland migration of the ecotone.

Understanding the organization of periphytic diatom assemblages along the freshwater-ecotone-coastal gradient in the southern Everglades and the mechanisms shaping those patterns is necessary to develop diatom indicators that can be used to document and predict rates of ecotone movement driven by saltwater intrusion and changing freshwater inflows. Diatom-based autecological indices are a trusted and popular tool in ecological assessments given the short generation rates, sensitivity to environmental fluctuations, and relative ease of diatom identification compared to other algae (Stevenson et al. 1999). They also are sentinels of changes in ecosystem properties including dependent food web structure and function (Trexler et al. 2015). Although the freshwater and coastal algal communities of the Everglades have been described in several studies (Wachnicka et al. 2010, La Hee and Gaiser 2012), the ecotone community remains less well understood and is an integral part in the development of diatom-based indicators of coastal transgression.

The goals of this study were to describe 1) the spatial and seasonal patterns of the predominant abiotic drivers of community structure - salinity and TP - in the southeastern Everglades, and 2) the ways in which these drivers shape community assembly of mat- 
dwelling diatoms. We hypothesized that the southern Everglades exhibits spatiallystructured gradients of salinity and TP that reflect differences in hydrological connectedness between fresh and marine water sources in western and eastern portions of the southern Everglades. We expected that periphytic diatom assemblages would be strongly controlled through species-sorting by these gradients in ways that would allow us to detect spatial boundaries and environmental thresholds. Seasonal differences in freshwater inputs from upstream were expected to result in ecotone boundaries occurring further inland during the dry season when freshwater flows are reduced, thus allowing marine water to intrude further inland. These patterns were predicted to be most pronounced in the eastern portions of the study region which are more deprived of upstream freshwater input.

\section{METHODS}

\section{Field and Laboratory Methods}

Patterns of environmental variation and diatom community structure along the freshwater-marine gradient of Everglades National Park, FL., USA were examined by sampling along a series of transects extending from oligotrophic, freshwater marshes through the ecotone and down to the northern edge of the fringing mangrove forests. Seven transects spanning the west-east extent of the southeast Everglades, from the Main Park Road in the west to the Model Lands in the east, were sampled once in the dry season (May) and once in the wet season (November) of 2014 and 2015 (Figure 1). Transect sites 
were set $1 \mathrm{~km}$ apart and, although the number of points differed among transects due to sampling constraints, were sufficient to capture the conductivity-P gradient.

We haphazardly selected three replicate points at each site for microbial mat collection and environmental measurements. At each of the 3 replicate points, surface (SW) and porewater $(\mathrm{PW})$ conductivity $\left(\mathrm{mS} \mathrm{cm}^{-1}\right)$ were measured with a YSI 30 Pro meter (Yellow Springs Inc., Yellow Springs, Ohio), water depth was measured by placing a meter stick on the soil surface and measuring to the surface of the water column, and soil depth was measured by inserting a steel rod into the soil until it hit bedrock and measuring the length of rod to the soil surface. Microbial mats were harvested from a $1 \mathrm{~m}^{2}$ quadrat at each replicate point and placed in a perforated graduated cylinder to drain excess water and measure total mat biovolume. A $120 \mathrm{~mL}$ subsample of the total harvested material was placed in a sample bag, transported back to the laboratory on ice, and stored in a $-20^{\circ} \mathrm{C}$ freezer until processed. Samples were thawed and transferred to a clean dish where plant material, rocks or other fragments were removed using forceps. The clean periphyton was relocated to a 500-mL beaker and homogenized with a hand-held blender. The volume of the homogenized sample was recorded to account for dilution with deionized water (DI) water used to facilitate cleaning and homogenizing the sample. The beaker was placed on a stir plate and subsampled for biomass, chlorophyll- $a$ (chl-a), total phosphorus (TP), and diatom assemblage composition.

The biomass subsample was placed in a drying oven at $80^{\circ} \mathrm{C}$ for $\geq 48 \mathrm{~h}$ to obtain a dry mass (g) measurement and then in a furnace where it was combusted at $500^{\circ} \mathrm{C}$ for $1 \mathrm{~h}$ to obtain the ash (mineral) mass (g). We calculated ash-free dry mass (AFDM) by the losson-ignition method as the difference between the ash mass and the total dry mass. AFDM 
was standardized to area $\left(\mathrm{g} \mathrm{m}^{-2}\right)$ by scaling the subsample biomass to the total area sampled and correcting for dilution with DI water during the cleaning process. We calculated mat mineral content as the $\%$ ash mass of the total dry mass. The chl- $a$ subsample was filtered onto Whatman $25 \mathrm{~mm}$ glass fiber filter (GFF) paper, frozen, and later subjected to $48 \mathrm{~h}$ $90 \%$ cold acetone extraction at $20 \mathrm{C}$. Chl- $a$ concentration was determined by flourometry using a Gildford FLUORO IV (Gilford Instrument, Oberlin, OH; excitation $435 \mathrm{~nm}$; emission $667 \mathrm{~nm}$ ). The TP subsample was dried at $80^{\circ} \mathrm{C}$ and pulverized with a mortar and pestle. We processed a known amount of each subsample and used colorimetric analysis to estimate TP concentration, expressed as $\mu \mathrm{g} / \mathrm{g}$ mat AFDM, following the methods of Solorzano and Sharp (1980). Mat TP was used as a proxy of TP in the environment because it has been shown to be a more sensitive gauge of $\mathrm{P}$ loading than concentrations in the water column. $\mathrm{P}$ inputs are rapidly taken up by microbial communities and vegetation making it virtually undetectable in the water column (Gaiser 2009).

Diatom subsamples were cleaned of mineral debris and organic matter using the sulfuric acid oxidation methods prescribed by Hasle and Fryxell (1970). We pipetted a known volume of cleaned diatom samples onto a glass coverslip, permanently mounted them it on a microscope slide with Naphrax (PhycoTech Inc., St. Joseph, Michigan) mounting medium, and viewed the diatoms under a compound light microscope (Zeiss Axioskop 2) equipped with differential interference contrast and a Leica DFC425 digital camera. We counted at least 500 valves along random transects at $600 \times$ magnification under oil immersion and identified them to the species level. Raw diatom counts were converted to relative abundance by standardized the number of valves counted for each species by the total number of valves counted. 


\section{Data Analysis}

Characterizing gradients and compositional similarity among sites

Species by site and environment by site data matrices were created for the dry and wet season by combining 2014 and 2015 data. Species present in less than 3 sites per season were removed and species counts were converted to relative abundances and arcsine square root transformed. The shortest distance from each transect site to the coast was calculated using the measure tool in QGIS (version 2.18). Sites were then categorized based on distance from coast quartiles as either NN (north-north; 12.4-17.0 km), N (north; 7.2-12.0 $\mathrm{km}), \mathrm{C}$ (central; 4.8-6.9 km), or S (south; 1.8-4.7 km) and transects were categorized as either western (transects 1-3) or eastern (transects 4-7). Spatial and seasonal differences in conductivity and TP were tested by analysis of variance (ANOVA) in R (R Core Team 2017 version 3.3.3). Multivariate analyses available in Primer (v6, PRIMER-E Ltd) were used to evaluate spatial-temporal patterns in diatom assemblages. Bray-Curtis similarity matrices were calculated between pairs of samples for dry and wet season datasets and subjected to principal coordinates analysis (PCO), hierarchical cluster analysis, analysis of similarity (ANOSIM) on clusters. The PCO ordinations for dry and wet seasons were linked to the corresponding cluster analysis for each season to define sites within the ordinations with $45 \%$ similarity in species composition. A categorical factor was generated based on the groupings determined by the cluster analysis (the number of levels in the cluster factor equal the number of groupings) and a one-way ANOSIM was used to test the significance of their species dissimilarity. Vectors representing environmental variables with $>0.6$ correlation coefficient (Pearson) were overlaid on the ordinations to visualize 
the strength and direction of association between the environmental drivers and clustering patters.

Assemblage boundaries along spatial gradients

A second set of PCO analyses were performed on averaged 2014 and 2015 species relative abundances for the dry and wet seasons to use for spatial boundary analyses. Because PCO axes are quantitative, the axis explaining the largest proportion of the variation in species composition among sites (axis 1) can be used to detect the area along each transect with the greatest rate of change in species dissimilarity. We did this by plotting PCO axis 1 scores for each site along the seven transects in sequence from furthest to closest to the coast and the vector with the greatest slope for each transect was defined qualitatively as an assemblage boundary (i.e., the area between two adjacent sites in a transect with the greatest dissimilarity in species composition) (Susan et al. 2003, Rodionov 2005). We were unable to quantitatively define the position of the assemblage boundary by performing significance tests that ensure locations with the greatest rate of community change are significantly different than would be expected at random, such as breakpoint or moving window regressions, because of the small number of sites in many of our transects. Many parts of the southeastern Everglades are remote and can only be accessed by helicopter which limited our sampling design. However, qualitative interpretation of ecotone location, such as non-statistical image analysis or field classification of vegetation zones, is common in the literature (Ross et al. 2000, Gaiser et al. 2009, Wasson et al. 2013), while studies having quantitatively described the position of ecotones by using significance tests are not as common, especially at scales larger than a 
single transect (Kroger et al. 2009, Ross et al. 2002, Walker et al. 2003).

\section{Assemblage and taxon thresholds along environmental gradients}

Species-specific and assemblage thresholds along conductivity and TP gradients, regardless of spatial location, were investigated using threshold indicator taxa analysis (TITAN) (TITAN R package; Baker and King 2010). TITAN was used to define the distribution and thresholds of individual indicator taxa, as well as assemblage-level response patterns and thresholds, to conductivity and TP gradients. TITAN was performed on dry and wet season datasets separately (2014 and 2015 combined) and on an aggregate dataset (dry and wet seasons for both years combined) to explore the sensitivity of those thresholds to seasonal variability in conductivity and TP gradients. TITAN calculates the environmental change point (CP), indicator value (IndVal), purity, and reliability of each taxon and labels them as either negative (z-) or positive $\left(\mathrm{z}^{+}\right)$taxa. Purity is defined as the proportion of bootstrap replicates with $\mathrm{CP}$ directions ( $\mathrm{z}-$ or $\mathrm{z}^{+}$) that agree with the observed response direction and reliability is the proportion of bootstrap CPs with significant IndVal scores $(\mathrm{p}<0.05)$ so that taxa with repeatable and consistently large IndVal scores are deemed reliable. Negative taxa are those that decline along the environmental gradient while positive taxa increase along the gradient. In this study, negative taxa are freshwater or oligotrophic species that decline in response to elevated conductivity or TP and positive taxa are brackish water or eutrophic species that increase when conductivity or TP are elevated. TITAN calculates the aggregate response of taxa to the environmental gradient by summing all $z_{-}$and $z^{+}$scores for each value of the environmental variable (sum(z-) and $\left.\operatorname{sum}\left(\mathrm{z}^{+}\right)\right)$to detect assemblage-level CPs for negative and positive taxa. Assemblage level 
thresholds are also calculated using only pure and reliable $(>0.95)$ indicator taxa; these filtered scores (fsum(z-) and fsum( $\left(\mathrm{z}^{+}\right)$) should resemble the unfiltered scores if impure and unreliable taxa do not contribute substantially to assemblage level patterns.

Filtered $\operatorname{sum}(\mathrm{z})$ scores were plotted against the environmental gradient to visualize assemblage response patterns and CPs where a synchronous decline or increase in pure and reliable indicator taxa occurs in response to the environmental gradient. We also plotted the CPs, and the distribution of $\mathrm{CP}$ values across bootstrap replicates, for individual, pure and reliable taxa against each environmental gradient and used the filtered assemblage thresholds for negative and positive taxa to mark lower and upper environmental boundaries, respectively. This allowed us to identify species that were restricted to certain ranges of the environmental gradients determined by the lower (FW or oligotrophic conditions) and upper (BW or eutrophic conditions) boundaries. Negative taxa with CPs below the lower boundary were categorized as FW or oligotrophic specialists and positive taxa with CPs above the upper boundary were classified as brackish water or eutrophic specialists, depending on the gradient. Furthermore, taxa with CPs within the range of

environmental values between the lower and upper thresholds were categorized as transition/ecotone species, regardless of their response direction.

\section{RESULTS}

$\underline{\text { Spatial and temporal characterization of conductivity and TP gradients }}$

Both latitudinal (inland to coast) and longitudinal (west to east) conductivity and TP gradients are present in the southeastern Everglades (Figure 2). However, latitudinal 
conductivity and TP gradients are not consistent across the southeastern Everglades and are influenced by proximity to Taylor Slough (TS) and hydrological connectivity between fresh and marine water sources. SW and PW conductivity significantly increases with proximity to the coast $(p<0.000)$ and was significantly greater in eastern than western transects (15.6 and 2.7 SW mS cm ${ }^{-1} \mathrm{p}<0.000 ; 23.8$ and $\left.6.3 \mathrm{PW} \mathrm{mS} \mathrm{cm}{ }^{-1}, \mathrm{p}<0.000\right)$. As predicted by the upside-down estuary model of the Everglades, TP increases with proximity to the coast but only in the 3 most western transects $(p=0.041)$. Mean mat TP in the eastern transects was significantly lower than in western transects (70.4 and 200.3 $\mu \mathrm{g} \mathrm{g}^{-1}, \mathrm{p}<0.000$ ) and did not express a gradient of increasing concentrations with proximity to coast ( $\mathrm{p}=0.721$ ). SW conductivity was significantly higher in the dry compared to the wet season $(\mathrm{p}<0.000)$, while PW conductivity $(\mathrm{p}=0.173)$ and TP $(\mathrm{p}=0.606)$ remained consistent between the two seasons.

\section{Characterizing gradients and compositional similarity among sites}

The first PCO axis explained $41.6 \%$ of the total variation in species composition for the dry season and $45.0 \%$ in the wet season while the second axis explained $15.3 \%$ and $13.9 \%$ in the dry and wet season, respectively (Figure 3). Cluster analysis on the site designations defined a priori based on distance from coast quartiles ( NN, N, C, and $\mathrm{S}$ ) identified 3 significantly different groups in the dry (ANOSIM, $\mathrm{p}=0.001$ ) and 4 groups in the wet season (ANOSIM, $\mathrm{p}=0.001$ ) at $45 \%$ similarity. Exploration of the sites contained in each group and the direction of environmental correlation vectors confirmed that these groupings corresponded to freshwater, transitional (i.e., ecotone), and coastal sites. In both the dry and wet seasons, sites categorized as $\mathrm{NN}$ fell into the freshwater cluster which also 
contained a few $\mathrm{N}$ and $\mathrm{C}$ sites from the western transects. The ecotone cluster in the dry season included N, C, and S sites from all transects while the coastal cluster consisted of S sites from the two most eastern transects (Figure 3a). The ecotone and coastal clusters in the wet season were not as clearly defined. The cluster analysis identified two ecotone groups containing a combination of $\mathrm{N}, \mathrm{C}$, and $\mathrm{S}$ sites whose separation was largely driven by $\mathrm{TP}$, and a coastal group consisting of $\mathrm{S}$ sites from western transects whose separation from the freshwater and ecotone groups was driven by conductivity (Figure 3b). TP and conductivity vectors were nearly orthogonal in both wet and dry season ordinations indicating that these variables were not correlated throughout the study region. PW and SW conductivity was negatively correlated with distance from coast, periphyton AFDM, and periphyton biovolume in both the dry and the wet season. The position and direction of PW and SW conductivity, distance from coast, and periphyton AFDM vectors indicate that the separation between fresh, ecotone, and coastal groups is strongly influenced by these variables. Summary statistics for environmental and periphyton variables used in the ordinations are available in Tables S.1 and S.2.

\section{$\underline{\text { Assemblage boundaries along spatial gradients }}$}

Diatom assemblage boundaries along each transect during the dry and wet seasons identified using PCO axes scores were used to qualitatively describe the location of the ecotone (Figure 4). We found that the ecotone occurs further inland west of Taylor Slough and dips coastward east of this major drainage system. The greatest dissimilarity in species composition in the two most western transects occurred between approximately 9 and 8 $\mathrm{km}$ from the coast and between 7 and $3 \mathrm{~km}$ from the coast in transects 3-7. There were no 
clear differences in the location of transect boundaries between the wet and dry season despite some minor variability. We plotted the boundary positions on satellite imagery maps and found that boundaries corresponded to the upper boundary of the white zone (Figure 5). These maps also depict averaged PW conductivity (Figure 5A) and TP (Figure 5B) at each site and show that the greatest conductivity and TP changes along each transect generally occurred at the upper boundary of the white zone as well.

Assemblage and taxon thresholds along environmental gradients

Diatom assemblage and taxa-specific thresholds along PW conductivity and TP gradients were identified for the dry and wet seasons and throughout the year (dry and wet seasons combined) using TITAN. The freshwater (declining) assemblage of pure and reliable indicator taxa experienced similarly low thresholds to PW conductivity in both the dry $\left(2.8 \mathrm{mS} \mathrm{cm}^{-1}\right)$ and wet $\left(2.3 \mathrm{mS} \mathrm{cm}^{-1}\right)$ seasons, and across all seasons $\left(2.4 \mathrm{mS} \mathrm{cm}^{-1}\right)$ (Figure 6, Table 1). The assemblage of brackish water (increasing) taxa, on the other hand, had a higher conductivity threshold in the dry $\left(30.7 \mathrm{mS} \mathrm{cm}^{-1}\right)$ compared to the wet (16.9 $\mathrm{mS} \mathrm{cm}{ }^{-1}$ ) season (Figure 6, Table 1). The conductivity threshold for the brackish water assemblage over all seasons was closer to the wet season threshold $\left(19.5 \mathrm{mS} \mathrm{cm}^{-1}\right)$.

TP thresholds for oligotrophic (declining) assemblage occurred at 48.7 and $45.3 \mu \mathrm{g} \mathrm{g}^{1}$ in the dry and wet season, respectively, and at $69.3 \mu \mathrm{g} \mathrm{g}^{-1}$ across all seasons (Figure 7, Table 2). The eutrophic (increasing) assemblage had a lower threshold to TP in the dry compared to the wet season (265.0 and $364.8 \mu \mathrm{g} \mathrm{g}^{-1}$, respectively). The overall TP threshold for eutrophic species was $285.1 .5 \mu \mathrm{g} \mathrm{g}^{-1}$. 
The TITAN-derived conductivity and TP thresholds for declining and increasing taxa assemblages presented above were used to establish lower and upper environmental boundaries along each gradient and define indicator taxa as freshwater (FW) or brackish water (BW) specialists and oligotrophic or eutrophic specialists based on their individual $\mathrm{CP}$ locations and distributions in the taxon plots (Figures 6 and 7, Tables 1 and 2). We found considerably more BW specialists compared to FW specialists regardless of season. Across all seasons, FW specialists (declining taxa with CPs below the assemblage threshold of $2.4 \mathrm{mS} \mathrm{cm}$ ch $^{-1}$ ) included Encyonema sjsp03, Encyonopsis microcephela, Kobayasiella subtilissima, and Sellaphora laevissima (Figure 6C). Indicator taxa classified as specialists of BW conditions (increasing taxa with CPs above the assemblage threshold of $19.5 \mathrm{mS} \mathrm{cm}^{-1}$ ) were Amphora acutiuscula, A. punctate, Brachysira aponina, Cyclotella, distinguenda, Envekadea vanlandinhamii, Fragilaria minuscula, Mastogloia asperuloides, M. braunii, Navicula duerrenbergiana, N. lenzii, N. salinicola, Nitzschia microcephela, Parlibellus panduriformis, Seminavis eulenstenii, S. witkowskii, and Synedra filiformis var. exilis (Figure 6C). Taxa with negative responses to TP (declining taxa) with thresholds below $69.3 \mu \mathrm{g} \mathrm{g}^{-1}$ were classified as oligotrophic specialists and included Cyclotella distinguenda, Diploneis parma, Encyonema mesianum, E. sjsp03, Navicula salinarum, Sellaphora laevissima, and S. stroemii (Figure 7C). Increasing indicator taxa of TP were classified as eutrophic specialists if their TP thresholds were above $285 \mu \mathrm{g} \mathrm{g}^{-1}$. Eutrophic specialists were Fragilaria ftsp16, F. minuscula, Gomphonema intricatum var. vibrio, Nitzschia nana, and N. palea var. debilis (Figure 7C). Taxa plates of freshwater, brackish water, oligotrophic, and eutrophic indicator species are presented in Figure S.1. 
Taxa with change points and distributions ( $\mathrm{CP}$ uncertainty) restricted to the range of environmental values between the lower and upper assemblage thresholds were classified as transitional/ecotone species of conductivity or TP gradients regardless of their response direction. Across all seasons, Amphora sulcata, Caponea caribbea, Cyclotella meneghiniania, D. oblongella, Fragilaria ftsp16, Mastogloia lanceolata, and Seminavis pusilla were identified as ecotone species of PW conductivity gradients (Figure 6C). Only two species, Fragilaria synegrotesca and Nitzschia ftsp16, could be classified as ecotone species in TP gradients. PW conductivity and TP change points for all species included in the analyses, along with their directionality (decreasing or increasing) and indicator value (asterisk denotes that both purity and reliability expectations are met), are reported in Tables 1 and 2 .

\section{DISCUSSION}

We demonstrate that the southern Everglades exhibits spatially-structured gradients of conductivity and $\mathrm{P}$ that are oriented in two dimensions and are often, but not always, positively correlated. We show that these gradients drive periphytic diatom assemblages in predictable ways allowing us to obtain PW conductivity and TP threshold estimates that define boundaries between assemblages that are characteristic of different portions of the gradients. These boundaries were difficult to define geographically due to the spatial complexity of the environmental gradients; nevertheless, we succeeded in qualitatively defining a spatial diatom-inferred ecotone that corresponded with the location of the "white-zone". We observed that the diatom-inferred ecotone occurred further inland west 
of Taylor Slough and dipped coastward east of this major drainage system but no seasonal variation in its location was observed. This was not surprising given that no significant seasonal differences were detected in PW conductivity or periphyton TP as hypothesized would occur during dry periods due to greater saltwater intrusion.

\section{$\underline{\text { Spatial and temporal characterization of conductivity and TP gradients }}$}

Conductivity and TP gradients exhibited a complex spatial-structure occurring in both latitudinal and longitudinal directions. As expected, conductivity increased linearly with proximity to the coast in all transects with a few exceptions where a positive linear relationship was not observed. These exceptions were attributed to the transect having one or more sites with a micro-topography favoring either freshwater ponding or intensified evaporation. We also observed an increasing gradient of PW conductivity from western to eastern transects. The 3 western transects are more hydrologically connected than the 4 eastern transects because they are closer to the two major drainage systems of the Everglades, namely Shark River Slough to the west and Taylor Slough at the center of the southern Everglades. The easternmost reaches of the southern Everglades are less hydrologically connected to upstream freshwater sources and can become hypersaline especially during the dry season (Sullivan et al. 2014). Although we found no seasonal differences in PW conductivity, SW conductivity was significantly greater in the dry season. During this time of year precipitation is low and managed freshwater flow from upstream is even more reduced. This allows higher conductivity water from Florida Bay to encroach inland and is exacerbated by high rates of evaporation and little to no freshwater flushing (Sklar et al. 1999). 
The "upside-down" estuary model predictions for the Everglades proposed by Childers et al. (2006), in which higher salinity, and thus proximity to the coast, are positively related to TP, was apparent in the 3 western transects of our study. However, this positive coupling of salinity and TP was not seen at our eastern transects where we found significantly lower TP levels despite higher salinities in both the dry and wet seasons. This is likely caused by the relatively low TP concentrations in Florida Bay, the primary marine water source into this area of the Everglades, compared to the Gulf of Mexico to which our western transects are more in connected (Fourqurean et al. 1992, Fourqurean et al. 1993, Sutula et al. 2003). The low TP levels found here may explain why we find cohesive, calcareous periphyton mats growing on dwarf Rhizophora mangle prop roots despite the high conductivity conditions in this area. The diatom assemblage inhabiting these prop root mats, however, are distinct from the typical assemblage associated with cohesive, calcareous mats in the freshwater, oligotrophic interior Everglades (Gaiser et al. 2011) suggesting that salt tolerance is the driving force behind diatom community assembly in the southeastern Everglades.

\section{Assemblage boundaries along spatial gradients}

We used qualitative methods to define diatom assemblage boundaries along individual transects and estimate the geographic position of a diatom-inferred ecotone. The diatom-inferred ecotone was located further inland west of Taylor Slough and dipped

coastward to the east following the shape of the coastline and the "white zone". When we depicted the diatom assemblage boundary on satellite imagery of the study area, we saw that this boundary coincided with the upper edge of the "white zone". PW conductivity and 
TP dissimilarity along each transect was often also greatest at the white zone suggesting that an environmental boundary is present and likely drives dynamics at the white zone (Figure 9). Ross et al. (2000) sampled several transects perpendicular to the Florida Bay coastline crossing the "white zone" and found a clear zonation in the plant community from mangrove-dominated woody vegetation along the coast, to a graminoid-mangrove mixture in the ecotone, followed by freshwater sawgrass marshes. Another study of the "white zone" by Ross et al. (2002), in which they sampled a single transect perpendicular to the Biscayne Bay coastline extending from freshwater marshes through the white zone and to the coast, found similar zonation patterns in vegetation and an even stronger zonation pattern in the diatom assemblages.

Our PCO ordinations illustrate that periphytic diatoms exhibit zonation along a distance from the coast gradient like those reported by Ross et al. (2002) and Wachnicka et al. (2010), but were also affected by the longitudinal (west to east) position of the transect. We suggest that assemblage dissimilarity between western and eastern transects was caused by variability in the shape and steepness of PW conductivity and TP gradients in western versus eastern portions of the southern Everglades. We also found seasonal differences in the way sites clustered together in the ordination. In the dry season, sites clustered tightly into 3 groups corresponding to freshwater, transitional, and brackish water assemblages. In the wet season, we found two transitional clusters and a smaller brackish water cluster suggesting that more freshwater availability during this time of year pushes the boundary between transitional and brackish assemblages further coastward and widens the ecotone. The length and direction of conductivity and distance from coast vectors on the PCO ordinations confirm that these variables strongly drive clustering patterns and, 
because they pointed in opposite directions, that they are negatively correlated to each other. Periphyton TP was also strongly correlated with assemblage structure; however, the TP vector was positioned orthogonally to both conductivity and distance from coast vectors indicating that TP was not coupled with conductivity or distance from coast throughout the study area. Although this was unexpected, the decoupling of conductivity and TP gradients allowed us to examine diatom assemblage breakpoints along conductivity and TP gradients separately since they were not correlated.

Assemblage and taxon thresholds along environmental gradients

The Threshold Indicator Taxa Analyses supported our hypothesis that diatom assemblages in the southern Everglades are structured by environmental filtering along conductivity and phosphorus gradients. Indicator assemblages and their environmental thresholds can be used to monitor and predict modifications to existing conductivity and phosphorus gradients in the southern Everglades caused by saltwater intrusion. We identified freshwater (negative taxa) and brackish water (positive taxa) assemblages along the PW conductivity gradient and oligotrophic (negative taxa) and eutrophic (positive taxa) assemblages along the TP gradient. However, assemblage composition and thresholds varied seasonally possibly reflecting taxa-specific life histories and differences in the length of PW conductivity and TP gradient in the dry and wet seasons. Although we focus our discussion on indicator taxa and assemblages identified over the entire study period, it is important to consider that the indicator power of taxa may be seasonally dependent and that environmental thresholds may shift seasonally as well. 
Both decreasing and increasing indicator assemblages often contained taxa with large uncertainty around the environmental threshold. Although these taxa were selected by the analysis as indicator species, the high variability of their conductivity or phosphorus thresholds potentially lessens their ability to signal small changes in these drivers making them less than ideal indicators. Generally, the freshwater assemblage declined at $2.4 \mathrm{mS}$ $\mathrm{cm}^{-1}$ (approximately $1 \mathrm{ppt}$ ) and was replaced by an assemblage of brackish water taxa around $20 \mathrm{mS} \mathrm{cm}^{-1}$ ( $\sim 12 \mathrm{ppt}$ ). Taxa with $\mathrm{CP}$ distributions spanning these lower and upper thresholds, such as M. calcarea and E. evergladianum among others, were considered generalist species. These two species are typically characterized as freshwater indicators but their wide distributions across the conductivity gradient suggests that they may not be the best indicators of low level salinity increase despite their dominance in calcareous periphyton mats. Wachnicka et al. (2010) reported salinity tolerances of 8.3 and $7.6 \mathrm{ppt}$ for E. evergladianum and M. calcarea (smithii), respectively; and Ross et al. (2002) described E. evergladianum as a "cosmopolitan" species because it was found throughout the coastal gradient sampled by them. Mazzei and Gaiser (2017) found that E. evergladianum relative abundance is more strongly driven by the availability of calcareous periphyton microhabitat than conductivity and that the strong negative relationship to this driver may be an indirect effect of low periphyton abundance in saline areas of the Everglades.

We identified more brackish water than freshwater indictors which was not unexpected given the proximity of our sampling sites to the coast. However, we found little agreement between our brackish water indicator species and those classified as brackish water indicators in other studies. Of the 16 brackish water indicator taxa identified in this study with thresholds above $20 \mathrm{mS} \mathrm{cm}^{-1}$, only three - B. aponina, C. distinguenda, and $M$. 
braunii were also recognized as coastal indicator species by Wachnicka et al. (2010) despite these two studies being conducted in the same area of the Everglades. This discrepancy in indicator selection may be caused by different analytical methods and/or species misidentification. While $B$. aponina and $C$. distinguenda were also reported as coastal indicators in Gaiser et al. (2005), none of our BW indicators coincided with those identified by Ross et al. (2002) or Nodine and Gaiser (2013). The lack of agreement between BW indicators identified in those studies and those identified in ours was not surprising since both the Gaiser et al. (2005) and Ross et al. (2002) studies were conducted along transects perpendicular to Biscayne Bay and the Nodine and Gaiser (2013) study took place along a salinity gradient in Charlotte Harbor estuary on the Gulf of Mexico Florida coast. These areas likely experience different environmental conditions and may have distinct diatom floras compared to transects sampled perpendicular to Florida Bay like ours. The inconsistencies among the few studies that have examined diatom assemblages along salinity gradients in the Everglades highlight the need for additional surveys of the diatom flora along coastal gradients throughout South Florida and the importance developing indicator species of saltwater intrusion for Biscayne Bay, Florida Bay, and Gulf of Mexico coasts separately.

Similarly, we found little to no agreement between our TP indicator taxa and those found in other studies (McCormick et al. 1996, Pan et al. 2000, Gaiser et al. 2006, Slate and Stevenson 2007, Wachnicka et al. 2010, La Hee and Gaiser 2012, Nodine and Gaiser 2013). For instance, many of the TP indicators with large uncertainties around their environmental CPs, including E. evergladianum, M. calcarea, $N$. palea var. debilis, and $N$. serpentiraphe, have been reported as both low and high TP indicators in previous studies. 
The diatom assemblage TP thresholds identified in this study were lower than those reported in other studies; for example, Gasier et al. (2004) found that periphyton biomass significantly decreased when mat TP was $>150 \mu \mathrm{g} \mathrm{g}^{-1}$ while other studies saw decreased biomass and altered species composition when mat TP was greater that $500 \mu \mathrm{g} \mathrm{g}^{-1}$ (Gaiser et al. 2006b). However, these studies took place in the northern Everglades where ambient $\mathrm{P}$ concentrations are higher, because of $\mathrm{P}$ loading from agriculture areas, compared to the southeastern coastal Everglades. This area is hydrologically disconnected from upstream agricultural $\mathrm{P}$ sources and instead receives most of this nutrient from P-limited Florida Bay. Average periphyton TP concentrations reported for upper Taylor Slough $\left(137 \mu \mathrm{g} \mathrm{g}^{-1}\right)$ and pristine areas of Shark River Slough (75-150 $\left.\mathrm{g} \mathrm{g}^{-1}\right)$ are higher than those we observed in upper freshwater portions of our western transects and all through the eastern transects (Iwaniac et al. 2006, Gaiser et al. 2006b). These differences in TP gradients, and possibly other environmental dissimilarities such as the interplay between conductivity and $\mathrm{P}$, among study areas may explain why there is so little overlap between TP indicator taxa identified in our study with others.

The existence of unique ecotone species has been proposed as one characteristic of ecotones but little evidence exists to support this hypothesis (Odum 1959, Walker et al. 2003, Kark and Rensburg 2006). In this study, we found several taxa with thresholds restricted to conductivity or TP values between the lower and upper assemblage thresholds that could be considered ecotone species. Seven taxa were identified as ecotone species of conductivity gradients while only 2 ecotone species of TP gradients were recognized. The ecotone of both the conductivity and TP gradients also contained many species from adjacent fresh and brackish water habitats. The existence of unique ecotone communities 
remains disputed in the literature with studies producing mixed results. For example, Baker et al. (2002) found that the bird community at the ecotone between woody and sedgeland areas in southeastern Australia was not unique, but rather contained species from both woody and sedge habitats. Similarly, a study on macroinvertebrate community structure along a salinity gradient from the freshwater Thames through the Thames estuary and into the North Sea found a continuum of species assemblages rather than a discrete estuarine community (Attrill and Rundle 2002). On the other hand, Walker et al. (2003) reported the presence of a few ecotone species $(\mathrm{n}=3)$ along a sequence of vegetation from coastal mangroves to upland pastures. Ecotone species were also reported by Lloyd et al. (2000) from four landscapes with different ecotone types in southwestern New Zealand. The inconsistencies among studies of ecotonal species suggests that the existence of species that are locally restricted to the ecotone is context-dependent rather than being an inherent property of ecotones.

\section{$\underline{\text { Conclusions }}$}

The "white zone" remains largely understudied but has been recognized as a critical area of interest to researchers who are investigating the effects of hydrologic management and saltwater intrusion on the ecology and biogeochemistry of the southern Everglades. Our study highlights that conductivity and periphyton TP are a powerful structuring force on diatom assemblage patterns in this area and that low-level changes in these drivers can shift diatom species composition, the consequences of which will resonate throughout the food web. This study is the first to develop diatom assemblage thresholds, and one of the few to provide taxa-specific thresholds, for conductivity and TP in the southern Everglades. 
We recommend greater spatially and temporally resolved surveys of diatom flora along salinity and TP gradients throughout the coastal Everglades which can be used to harmonize indicator species catalogs and calibrate taxa and assemblage thresholds by region for more accurate assessments and predictions of saltwater intrusion and associated P inputs. This project represents a stepping stone in the effort to extend the use of predictive diatom metrics to the southern Everglades. There they can be used to assess and predict the movement of ecological boundaries driven by saltwater intrusion and changing freshwater inflows, in an area of the ecosystem where this balance is most pronounced.

\section{ACKNOWLEDGMENTS}

We thank Adam Hines, Rafael Travieso, Luca Marazzi, and Shelby Servais for field assistance; Franco Tobias for field and laboratory assistance particularly with species identification; and Ken Feeley, John Kominoski, Luca Marazzi, Jennifer Richards, and Michael Ross for reviewing and/or providing comments that significantly improved the quality of this manuscript. This work was supported in part by the National Science Foundation through the Florida Coastal Everglades Long-Term Ecological Research program under Cooperative Agreements DEB-1237517, DBI-0620409, and DEB9910514, by the ForEverglades Scholarship from the Everglades Foundation, and by Tiffany Troxler through funding for the Southeastern Everglades Ecosystem Monitoring Program through a grant from the South Florida Water Management District. This is contribution number 851 from the Southeast Environmental Research Center in the Institute of Water and Environment at Florida International University. 


\section{LITERATURE CITED}

Attrill, M.J. \& Rundle, S.D., 2002. Ecotone or ecocline: ecological boundaries in estuaries. Estuarine, Coastal and Shelf Science, 55: 929-936.

Baker, J., French, K. and Whelan, R.J., 2002. The edge effect and ecotonal species: bird communities across a natural edge in southeastern Australia. Ecology, 83:30483059.

Baker, M.E. \& King, R.S., 2010. A new method for detecting and interpreting biodiversity and ecological community thresholds. Methods in Ecology and Evolution, 1:25-37.

Briceño, H., Miller, G., Davis III, S. E. 2014. Relating freshwater flow with estuarine water quality in the Southern Everglades mangrove ecotone. Wetlands, 34:101111.

Chase, J.M. \& Myers, J.A., 2011. Disentangling the importance of ecological niches from stochastic processes across scales. Philosophical Transactions of the Royal Society of London B: Biological Sciences, 366: 2351-2363.

Childers, D. L., Boyer, J. N., Davis, S. E., Madden, C. J., Rudnick, D. T., Sklar, F. H. 2006. Relating precipitation and water management to nutrient concentrations in the oligotrophic "upside-down" estuaries of the Florida Everglades. Limnology and Oceanography, 51: 602-616.

Clarke K.R. \& Gorley, R.N. (editors). 2006. Primer v6: User Manual/Tutorial. Plymouth: PRIMER-E.

Davis, S. M., Childers, D. L., Lorenz, J. J., Wanless, H. R., Hopkins, T. E. 2005. A conceptual model of ecological interactions in the mangrove estuaries of the Florida Everglades. Wetlands, 25:832-842.

Peters, D.P., C., Gosz, J.R., Pockman, W.T., Small, E.E., Parmenter, R.R., Collins, S.L., Muldavin, E., 2006. Integrating patch and boundary dynamics to understand and predict biotic transitions at multiple scales. Landscape Ecology, 21: 19-33.

Egler, F. E. 1952. Southeast saline Everglades vegetation, Florida and its management. Vegetatio, 3: 213-265.

Fortin, M.J., Olson, R.J., Ferson, S., Iverson, L., Hunsaker, C., Edwards, G., Levine, D., Butera, K. and Klemas, V., 2000. Issues related to the detection of boundaries. Landscape Ecology, 15: 453-466.

Fourqurean, J.W., Jones, R.D. and Zieman, J.C., 1993. Process influencing water column nutrient characteristics and phosphorus limitation of phytoplankton biomass in 
Florida Bay, FL, USA: inferences from spatial distributions. Estuarine, Coastal and Shelf Science, 36: 295-314.

Fourqurean, J.W., Zieman, J.C. and Powell, G.V., 1992. Phosphorus limitation of primary production in Florida Bay: evidence from $\mathrm{C}: \mathrm{N}$ : P ratios of the dominant seagrass Thalassia testudinum. Limnology and Oceanography, 37: 162-171.

Frankovich, T. A., Gaiser, E. E., Zieman, J. C., Wachnicka, A. H. 2006. Spatial and temporal distributions of epiphytic diatoms growing on Thalassia testudinum Banks ex König: relationships to water quality. Hydrobiologia, 569:259-271.

Gaiser, E. 2009. Periphyton as an indicator of restoration in the Florida Everglades. Ecological Indicators, 9:37-45.

Gaiser, E. E., McCormick, P. V., Hagerthey, S. E., Gottlieb, A. D. 2011. Landscape patterns of periphyton in the Florida Everglades. Critical Reviews in Environmental Science and Technology, 41: 92-120.

Gaiser, E. E., Trexler, J. C., Jones, R. D., Childers, D. L., Richards, J. H., Scinto, L. J. 2006b. Periphyton responses to eutrophication in the Florida Everglades: crosssystem patterns of structural and compositional change. Limnology and Oceanography, 51:617:630

Gaiser, E., Wachnicka, A., Ruiz, P., Tobias, F. and Ross, M., 2005. Diatom indicators of ecosystem change in subtropical coastal wetlands. Estuarine Indicators. CRC Press, Boca Raton, FL, 127144.

Gaiser, E.E., Scinto, L.J., Richards, J.H., Jayachandran, K., Childers, D.L., Trexler, J.C., Jones, R.D., 2004. Phosphorus in periphyton mats provides the best metric for detecting low-level P enrichment in an oligotrophic wetland. Water Research, 38: 507-516.

Gaiser, E.E., Zafiris, A., Ruiz, P.L., Tobias, F.A., Ross, M.S., 2006a. Tracking rates of ecotone migration due to salt-water encroachment using fossil mollusks in coastal South Florida. Hydrobiologia, 569:237-257.

Hagerthey, S. E., Bellinger, B. J., Wheeler, K., Gantar, M., Gaiser, E. 2011. Everglades periphyton: a biogeochemical perspective. Critical Reviews in Environmental Science and Technology, 41:309-343.

Heino, J. \& Soininen, J. 2005. Assembly rules and community models for unicellular organisms: patterns in diatoms of boreal streams. Freshwater Biology, 50:567577.

Heino, J., Melo, A.S., Siqueira, T., Soininen, J., Valanko, S., Bini, L.M., 2015. Metacommunity organisation, spatial extent and dispersal in aquatic systems: patterns, processes and prospects. Freshwater Biology, 60:845-869. 
Iwaniec, D.M., Childers, D.L., Rondeau, D., Madden, C.J. and Saunders, C., 2006. Effects of hydrologic and water quality drivers on periphyton dynamics in the southern Everglades. Hydrobiologia, 569:223-235.

Jacquez, G.M., Maruca, S. and Fortin, M.J., 2000. From fields to objects: a review of geographic boundary analysis. Journal of Geographical Systems, 2: 221-241.

Jiang, J., Gao, D., DeAngelis, D.L., 2012. Towards a theory of ecotone resilience: coastal vegetation on a salinity gradient. Theoretical Population Biology, 82:29-37.

Kark, S. and Van Rensburg, B.J., 2006. Ecotones: marginal or central areas of transition? Israel Journal of Ecology \& Evolution, 52: 29-53.

Kent, M., Moyeed, R.A., Reid, C.L., Pakeman, R. and Weaver, R., 2006. Geostatistics, spatial rate of change analysis and boundary detection in plant ecology and biogeography. Progress in Physical Geography, 30: 201-231.

La Hée, J. M., \& E. E. Gaiser. 2012. Benthic diatom assemblages as indicators of water quality in the Everglades and three tropical karstic wetlands. Freshwater Science, 31:205-221.

Lee, S. S., Gaiser, E. E., Trexler, J. C. 2013. Diatom-based models for inferring hydrology and periphyton abundance in a subtropical karstic wetland: Implications for ecosystem-scale bioassessment. Wetlands, 33:157-173.

Leibold, M.A., Holyoak, M., Mouquet, N., Amarasekare, P., Chase, J.M., Hoopes, M.F., Holt, R.D., Shurin, J.B., Law, R., Tilman, D., Loreau, M., 2004. The metacommunity concept: a framework for multi-scale community ecology. Ecology Letters, 7: 601-613.

Lloyd, K.M., McQueen, A.A., Lee, B.J., Wilson, R.C., Walker, S. and Wilson, J.B., 2000. Evidence on ecotone concepts from switch, environmental and anthropogenic ecotones. Journal of Vegetation Science, 11: 903-910.

Mazzei, V. and Gaiser, E., 2017. Scale and spatial consistency of specialization in an endemic and abundant freshwater diatom from the Caribbean Basin. Freshwater Science, 36: 542-554.

McCormick, P. V. \& O'Dell, M. B. 1996. Quantifying periphyton responses to phosphorus in the Florida Everglades: a synoptic-experimental approach. Journal of the North American Benthological Society, 15:450-468.

Nicholls, K.H., 2011. Detection of regime shifts in multi-species communities: the Bay of Quinte phytoplankton example. Methods in Ecology and Evolution, 2:416-426.

Nodine, E.R. and Gaiser, E.E., 2014. Distribution of diatoms along environmental gradients in the Charlotte Harbor, Florida (USA), estuary and its watershed: 
implications for bioassessment of salinity and nutrient concentrations. Estuaries and coasts, 37: 864-879.

Odum, E.P., 1959. Fundamentals of ecology. WB Saunders Company.

Pan, Y., Stevenson, R.J., Vaithiyanathan, P., Slate, J. and Richardson, C.J., 2000. Changes in algal assemblages along observed and experimental phosphorus gradients in a subtropical wetland, USA. Freshwater Biology, 44: 339-353.

Potapova, M. and Charles, D.F., 2003. Distribution of benthic diatoms in US rivers in relation to conductivity and ionic composition. Freshwater Biology, 48:13111328 .

Price, R. M., Swart, P. K., Fourqurean, J. W. 2006. Coastal groundwater discharge-an additional source of phosphorus for the oligotrophic wetlands of the Everglades. Hydrobiologia, 569:23-36.

Rodionov, S. N. 2005. A brief overview of the regime shift detection methods. LargeScale Disturbances (Regime Shifts) and Recovery in Aquatic Ecosystems: Challenges for Management Toward Sustainability, 17-24.

Ross, M. S., Gaiser, E.E., Meeder, J.F., Lewin, M.T. 2002. Multi-taxon analysis of the "white zone", a common ecotonal feature of South Florida coastal wetlands. Everglades, Florida Bay, and Coral Reefs of the Florida Keys. CRC Press, Delray Beach, FL, USA: 205-238.

Ross, M.S., Meeder, J.F., Sah, J.P., Ruiz, P.L., Telesnicki, G.J. 2000. The Southeast Saline Everglades revisited: a half-century of coastal vegetation change. Journal of Vegetation Science, 11:101-112

Saha, A.K., Saha, S., Sadle, J., Jiang, J., Ross, M.S., Price, R.M., Sternberg, L.S., Wendelberger, K.S., 2011. Sea level rise and South Florida coastal forests. Climatic Change, 107: 81-108.

Sklar, F., McVoy, C., Van Zee, R., Gawlik, D., Swift, D., Park, W., Fitz, C., Wu, Y., Rudnick, D., Fontaine, T. and Miao, S., 1999. Hydrologic needs: the effects of altered hydrology on the Everglades. Everglades Interim Report, SFWMD, West Palm Beach, FL, USA.

Slate, J.E. and Stevenson, R.J., 2007. The diatom flora of phosphorus-enriched and unenriched sites in an Everglades marsh. Diatom Research, 22: 355-386.

Stevenson, R.J., Pan, Y., van Dam, H., 1999. Assessing environmental conditions in rivers and streams with diatoms in The Diatoms: Applications for the Environmental and Earth Sciences, 2nd ed. Cambridge University Press, Cambridge. 
Sullivan, P.L., Price, R.M., Schedlbauer, J.L., Saha, A., Gaiser, E.E., 2014. The influence of hydrologic restoration on groundwater-surface water interactions in a karst wetland, The Everglades (FL, USA). Wetlands, 34:23-35.

Sutula, M.A., Perez, B.C., Reyes, E., Childers, D.L., Davis, S., Day, J.W., Rudnick, D. and Sklar, F., 2003. Factors affecting spatial and temporal variability in material exchange between the Southern Everglades wetlands and Florida Bay (USA). Estuarine, Coastal and Shelf Science, 57: 757-781.

Taylor, W.A. 2000. Change-Point Analysis: A Powerful New Tool for Detecting Changes. WEB: http://www.variation.com/cpa/tech/changepoint.html.

Trexler, J.C., Gaiser, E.E., Kominoski, J.S. and Sanchez, J., 2015. The role of periphyton mats in consumer community structure and function in calcareous wetlands: lessons from the Everglades. Microbiology of the Everglades Ecosystem. Science Publications, CRC Press, Boca Raton, pp.155-179.

Troxler, T.G., Childers, D.L., Madden, C.J., 2014. Drivers of decadal-scale change in southern Everglades wetland macrophyte communities of the coastal ecotone. Wetlands, 34:81-90.

Wachnicka, A., Gaiser, E., Boyer, J. 2011. Ecology and distribution of diatoms in Biscayne Bay, Florida (USA): implications for bioassessment and paleoenvironmental studies. Ecological Indicators, 11:622-632.

Wachnicka, A., Gaiser, E.E., Collins L., Frankovich, T. Boyer, J. 2010. Distribution of diatoms and development of diatom-based models for inferring salinity and nutrient concentrations in Florida Bay and adjacent coastal wetlands of South Florida. Estuaries and Coasts, 33:1080-1098.

Walker, S., Wilson, J.B., Steel, J.B., Rapson, G.L., Smith, B., King, W.M., Cottam, Y.H., 2003. Properties of ecotones: evidence from five ecotones objectively determined from a coastal vegetation gradient. Journal of Vegetation Science, 14: 579-590.

Wanless, H. R. \& Vlaswinkel, B. 2005. Coastal landscape and channel evolution affecting critical habitats at Cape Sable, Everglades National Park, Florida. Final Report to Everglades National Park, United States Department of the Interior, Homestead, FL, USA.

Wasson, K., Woolfolk, A., Fresquez, C., 2013. Ecotones as indicators of changing environmental conditions: rapid migration of salt marsh-upland boundaries. Estuaries and Coasts, 36: 654-664 
Table 2-1. Species list including authority, taxon codes, and Threshold Indicator Taxa Analysis derived environmental change points $(\mathrm{CP})$, indicator values (IndVal), and response direction (declining $=\mathrm{z}-$; increasing $=\mathrm{z}^{+}$) for porewater conductivity in the dry, wet, and overall (both seasons combined). Sum(z) scores represent assemblage level CP using all taxa and fsum(z) scores are filtered for pure and reliable taxa only. An asterisk next to the Indval denotes pure and reliable indicator taxa ( $>0.95)$ (see taxa plots in Figures 5 and 7).

\begin{tabular}{|c|c|c|c|c|c|c|c|c|c|c|c|c|}
\hline \multirow{2}{*}{ No. } & & & & \multicolumn{3}{|c|}{ Dry } & \multicolumn{3}{|c|}{ Wet } & \multicolumn{3}{|c|}{ Overall } \\
\hline & Species & Authority & Code & $\mathrm{PW} \mathrm{CP}(\mathrm{mS} / \mathrm{cm})$ & $+/$ taxa & $\begin{array}{c}\text { IndVal } \\
(\%)\end{array}$ & $\mathrm{PW}$ CP $(\mathrm{mS} / \mathrm{cm})$ & $+/-\operatorname{taxa}$ & $\begin{array}{c}\text { IndVal } \\
(\%)\end{array}$ & $\mathrm{PW} \mathrm{CP}(\mathrm{mS} / \mathrm{cm})$ & $+/-$ taxa & $\begin{array}{c}\text { IndVal } \\
(\%)\end{array}$ \\
\hline 1 & Achnanthes amoena & Hustedt, 1952 & ACAMOAMO & --- & --- & --- & --- & --- & --- & 0.4 & $\mathrm{z}-$ & 16.6 \\
\hline 2 & Amphora acutiuscula & Kützing, 1844 & AMACUACU & 46.9 & $\mathrm{z}^{+}$ & $62.5^{*}$ & 16.9 & $\mathrm{z}^{+}$ & 20.6 & 44.2 & $\mathrm{z}^{+}$ & $39.8^{*}$ \\
\hline 3 & Amphora coffeaeformis aponina & Archibald \& Schoeman, 1984 & AMCOFAPO & --- & --- & --- & 7.3 & $\mathrm{z}^{+}$ & 14.3 & 7.4 & $\mathrm{z}^{+}$ & 7.1 \\
\hline 4 & Amphora punctata & & AMPUNPUN & 30.7 & $\mathrm{z}^{+}$ & $59.5^{*}$ & 20.6 & $\mathrm{z}^{+}$ & $52.8^{*}$ & 29.4 & $\mathrm{z}^{+}$ & $53.3^{*}$ \\
\hline 5 & Amphora sulcata & Brébisson, 1854 & AMSULSUL & 3.7 & $\mathrm{z}^{+}$ & $90.0^{*}$ & 7.5 & $\mathrm{z}^{+}$ & $80.0^{*}$ & 3.1 & $\mathrm{z}^{+}$ & $84.1^{*}$ \\
\hline 6 & Amphora veneta & Kützing, 1844 & AMVMSP01 & 44.2 & $\mathrm{z}^{+}$ & 55.6 & 29.4 & $\mathrm{z}^{+}$ & $55.2 *$ & 29.4 & $\mathrm{z}^{+}$ & $40.2^{*}$ \\
\hline 7 & Brachysira aponina & Kützing, 1836 & BRAPOAPO & 30.7 & $\mathrm{z}^{+}$ & $60.0^{*}$ & 7.3 & $\mathrm{z}^{+}$ & 14.3 & 48.9 & $\mathrm{z}^{+}$ & $78.8^{*}$ \\
\hline 8 & Brachysira cf. aponina & Kützing, 1836 & BRCFAPO & --- & --- & --- & 23.0 & $\mathrm{z}^{+}$ & $50.7^{*}$ & 15.2 & $\mathrm{z}^{+}$ & $23.4^{*}$ \\
\hline 9 & Brachysira microcephela & (Grunow) Compère, 1986 & BRMICMIC & 12.9 & $\mathrm{z}^{+}$ & 60.5 & 0.3 & $\mathrm{z}^{+}$ & 56.3 & 12.9 & $\mathrm{z}^{+}$ & 58.0 \\
\hline 10 & Caponea caribbea & Podzorski, 1984 & CPCARCAR & 43.3 & $\mathrm{z}^{+}$ & $84.3 *$ & 10.1 & $\mathrm{z}^{+}$ & $77.5^{*}$ & 13.0 & $\mathrm{z}^{+}$ & $68.3^{*}$ \\
\hline 11 & Cyclotella distinguenda & Hustedt, 1927 & CYSTRSTR & 44.2 & $\mathrm{z}^{+}$ & 83.9 & 29.4 & $\mathrm{z}^{+}$ & 54.9 & 29.4 & $\mathrm{z}^{+}$ & $62.8^{*}$ \\
\hline 12 & Cyclotella meneghiniania & Kützing , 1844 & STMENMEN & 9.5 & $\mathrm{z}^{+}$ & $80.3^{*}$ & 18.8 & $\mathrm{z}^{+}$ & $91.9^{*}$ & 9.2 & $\mathrm{z}^{+}$ & $85.0^{*}$ \\
\hline 13 & Diploneis oblongella & Cleve-Euler, 1922 & DIOBLOBL & 3.7 & $\mathrm{z}^{+}$ & 60.35 & 6.6 & $\mathrm{z}^{+}$ & 65.1 & 6.0 & $\mathrm{z}^{+}$ & $63.6^{*}$ \\
\hline 14 & Diploneis parma & Cleve, 1891 & DIPARPAR & 11.9 & $\mathrm{z}^{+}$ & $63.9^{*}$ & 27.6 & $\mathrm{z}^{+}$ & 50.3 & 12.9 & $\mathrm{z}^{+}$ & $51.2^{*}$ \\
\hline 15 & Diploneis vmspl & & DIPVMSP01 & --- & --- & --- & 18.8 & $\mathrm{z}^{+}$ & $36.0^{*}$ & 11.9 & $\mathrm{z}^{+}$ & $18.6^{*}$ \\
\hline 16 & Encyonema evergladianum & Krammer, 1997 & ENEVEEVE & 5.0 & z- & $76.4^{*}$ & 21.4 & z- & $89.1 *$ & 19.5 & z- & $79.1 *$ \\
\hline 17 & Encyonema mesianum & (Cholnoky) D.G.Mann, 1990 & ENMESMES & 3.7 & z- & $62.3^{*}$ & 6.6 & $\mathrm{z}-$ & $66.8^{*}$ & 3.7 & $\mathrm{z}-$ & $56.3^{*}$ \\
\hline 18 & Encyonema silesiacum elegans & Krammer, 1997 & ENSILELE & 1.2 & $z-$ & 6.0 & 0.7 & $\mathrm{z}-$ & $47.5^{*}$ & 0.8 & $\mathrm{z}-$ & 25.3 \\
\hline 19 & Encyonema sjsp03 & & ENSJSP03 & 2.1 & z- & $57.9^{*}$ & 2.3 & z- & $42.0^{*}$ & 2.0 & z- & $54.5^{*}$ \\
\hline 20 & Encyonopsis microcephela & (Grunow) Krammer, 1997 & ECMICMIC & 2.5 & $z-$ & $65.7 *$ & 1.3 & $z-$ & $75.6^{*}$ & 1.3 & $z-$ & $82.6^{*}$ \\
\hline 21 & Envekadea metezeltinii & Lee et al., 2013 & EVMETMET & 30.7 & $\mathrm{z}^{+}$ & $85.4 *$ & 16.9 & $\mathrm{z}^{+}$ & $78.1^{*}$ & 13.0 & $\mathrm{z}^{+}$ & $60.0^{*}$ \\
\hline 22 & Envekadea vanlandinghamii & Graeff, 2013 & EVVANVAN & 30.7 & $\mathrm{z}^{+}$ & $48.1^{*}$ & 30.7 & $\mathrm{z}^{+}$ & $87.9^{*}$ & 22.3 & $\mathrm{z}^{+}$ & $57.3^{*}$ \\
\hline 23 & Fragilaria ftsp16 & & FAFTSP16 & 5.0 & $\mathrm{z}^{+}$ & $80.4 *$ & 6.6 & $\mathrm{z}^{+}$ & $82.3^{*}$ & 3.1 & $\mathrm{z}^{+}$ & $74.3^{*}$ \\
\hline 24 & Fragilaria minuscula & (Grunow) Williams,1987 & FAMINMIN & 25.8 & $\mathrm{z}^{+}$ & $74.1 *$ & 22.8 & $\mathrm{z}^{+}$ & $59.2 *$ & 19.5 & $\mathrm{z}^{+}$ & $55.6^{*}$ \\
\hline 25 & Fragilaria nanana & Lange-Bertalot, 1993 & FANANNAN & 7.6 & $z-$ & 19.2 & 9.8 & $\mathrm{z}^{+}$ & $26.7 *$ & 9.8 & $\mathrm{z}^{+}$ & 12.2 \\
\hline 26 & Fragilaria synegrotesca & Lange-Bertalot, 1993 & FASYNSYN & 3.1 & $\mathrm{z}^{+}$ & 52.3 & 23.0 & z- & 61.2 & 30.3 & $\mathrm{z}-$ & 55.6 \\
\hline 27 & Gomphonema intricatum vibrio & (Ehrenberg) Cleve, 1894 & GOINTVIB & 1.7 & z- & 37.6 & 9.8 & $\mathrm{z}-$ & $38.7^{*}$ & 9.8 & $\mathrm{z}-$ & $31.9^{*}$ \\
\hline 28 & Kobayasiella parasubtilissima & Lange-Bertalot, 1999 & KOPARPAR & 2.0 & $\mathrm{z}-$ & 23.1 & --- & --- & --- & 1.9 & $\mathrm{z}-$ & 12.9 \\
\hline 29 & Kobayasiella subtilissima & Lange-Bertalot, 1999 & KOSUBSUB & 1.2 & z- & 51.5 & --- & --- & --- & 1.3 & z- & $63.4^{*}$ \\
\hline
\end{tabular}




\begin{tabular}{|c|c|c|c|c|c|c|c|c|c|c|c|c|}
\hline 30 & Mastogloia asperuloides & Hustedt, 1933 & MAASPASP & 44.2 & $\mathrm{z}^{+}$ & 42.9 & 27.6 & $\mathrm{z}^{+}$ & $73.9 *$ & 29.4 & $\mathrm{z}^{+}$ & $46.5^{*}$ \\
\hline 31 & Mastogloia braunii & Grunow, 1863 & MABRABRA & 30.7 & $\mathrm{z}^{+}$ & $56.7 *$ & 18.8 & $\mathrm{z}^{+}$ & $34.0 *$ & 44.2 & $\mathrm{z}^{+}$ & $63.5^{*}$ \\
\hline 32 & Mastogloia calcarea & Lee et al., 2014 & MACALCAL & 43.3 & $\mathrm{z}-$ & $96.8^{*}$ & 16.9 & z- & $86.8^{*}$ & 30.3 & $z-$ & $84.1 *$ \\
\hline 33 & Mastogloia lanceolata & Thwaites ex W.Smith, 1856 & MALANLAN & 6.7 & $\mathrm{z}^{+}$ & $82.6^{*}$ & 6.6 & $\mathrm{z}^{+}$ & $86.9^{*}$ & 3.1 & $\mathrm{z}^{+}$ & $84.8^{*}$ \\
\hline 34 & Mastogloia pseduosmithii & Lee et al., 2014 & MAPSEPSE & 2.8 & $\mathrm{z}^{+}$ & 11.9 & 0.3 & $\mathrm{z}^{+}$ & 13.0 & 2.8 & $\mathrm{z}^{+}$ & 11.15 \\
\hline 35 & Navicula bulnheimii & Grunow, 1880 & NABULBUL & --- & --- & --- & 22.8 & $\mathrm{z}^{+}$ & $85.3^{*}$ & 15.0 & $\mathrm{z}^{+}$ & $38.8^{*}$ \\
\hline 36 & Navicula cryptotenella & Lange-Bertalot, 1985 & NACRYCRY & 44.2 & $\mathrm{z}^{+}$ & 92.7 & 0.7 & $\mathrm{z}-$ & $73.7^{*}$ & 44.2 & $\mathrm{z}^{+}$ & 87.2 \\
\hline 37 & Navicula duerrenbergiana & Hustedt, 1934 & NADUEDUE & --- & --- & --- & 27.6 & $\mathrm{z}^{+}$ & $71.4^{*}$ & 22.8 & $\mathrm{z}^{+}$ & $32.5^{*}$ \\
\hline 38 & Navicula lenzii & Hustedt, 1950 & NALENLEN & --- & --- & --- & 22.8 & $\mathrm{z}^{+}$ & $57.9^{*}$ & 22.8 & $\mathrm{z}^{+}$ & $26.0 *$ \\
\hline 39 & Navicula radiosa & Kützing, 1844 & NARADRAD & 1.2 & $\mathrm{z}-$ & $72.9 *$ & 1.6 & z- & 19.51 & 1.0 & $\mathrm{z}-$ & 45.0 \\
\hline 40 & Navicula salinarum & Grunow, 1880 & NASALSAL & 24.8 & $\mathrm{z}^{+}$ & 58.2 & 16.9 & $\mathrm{z}^{+}$ & $57.0^{*}$ & 17.4 & $\mathrm{z}^{+}$ & $45.8^{*}$ \\
\hline 41 & Navicula salinicola & Hustedt, 1939 & NASAISAI & 30.7 & $\mathrm{z}^{+}$ & $89.4 *$ & 29.4 & $\mathrm{z}^{+}$ & $48.0 *$ & 29.4 & $\mathrm{z}^{+}$ & $69.0^{*}$ \\
\hline 42 & Nitzschia acicularis & (Kützing) W.Smith, 1853 & NIACIACI & --- & --- & --- & 23.0 & $\mathrm{z}^{+}$ & $28.9^{*}$ & 15.2 & $\mathrm{z}^{+}$ & 13.8 \\
\hline 43 & Nitzschia ftsp16 & & NIFTSP16 & 5.0 & $\mathrm{z}^{+}$ & $90.7 *$ & 2.3 & $\mathrm{z}^{+}$ & $85.4 *$ & 5.0 & $\mathrm{z}^{+}$ & $83.0^{*}$ \\
\hline 44 & Nitzschia microcephela & Grunow, 1880 & NIMICMIC & 24.8 & $\mathrm{z}^{+}$ & $60.2 *$ & 22.1 & $\mathrm{z}^{+}$ & $79.6^{*}$ & 22.5 & $\mathrm{z}^{+}$ & $65.2^{*}$ \\
\hline 45 & Nitzschia cf. microcephela & Grunow, 1880 & NICFMICMIC & --- & --- & --- & 29.4 & $\mathrm{z}^{+}$ & $55.1 *$ & 25.5 & $\mathrm{z}^{+}$ & $31.5^{*}$ \\
\hline 46 & Nitzschia nana & Grunow, 1881 & NINANNAN & 3.1 & $\mathrm{z}^{+}$ & 15.6 & 6.6 & $\mathrm{z}^{+}$ & 13.9 & 3.1 & $\mathrm{z}^{+}$ & 14.9 \\
\hline 47 & Nitzschia palea debilis & (Kützing) Grunow, 1880 & NIPALDEB & 44.2 & $\mathrm{z}-$ & 68.1 & 21.4 & z- & $78.9 *$ & 1.8 & $\mathrm{z}-$ & 64.1 \\
\hline 48 & Nitzschia cf scalaris & (Ehrenberg) Smith, 1853 & NISCASCA & --- & --- & --- & --- & --- & --- & --- & --- & --- \\
\hline 49 & Nitzschia serpentiraphe & Lange-Bertalot, 1993 & NISERSER & 3.1 & $\mathrm{z}-$ & $69.6^{*}$ & 2.6 & $\mathrm{z}-$ & $76.9^{*}$ & 3.7 & $\mathrm{z}-$ & $68.1 *$ \\
\hline 50 & Parlibellus panduriformis & John, 1991 & PAPANPAN & 44.2 & $\mathrm{z}^{+}$ & 42.9 & --- & --- & --- & 27.9 & $\mathrm{z}^{+}$ & $35^{*}$ \\
\hline 51 & Pinnularia major & (Kützing) Rabenhorst, 1853 & PINVIRVIR & 18.5 & $z-$ & 7.7 & 1.5 & $\mathrm{z}-$ & 15.1 & 18.5 & z- & 7.5 \\
\hline 52 & Pleurosigma salinarum & (Grunow) Grunow, 1880 & PLSALSAL & --- & --- & --- & 29.4 & $\mathrm{z}^{+}$ & 20.1 & 29.4 & $\mathrm{z}^{+}$ & 9.3 \\
\hline 53 & Pleurosira vmsp1 & & PEVMSP01 & --- & --- & --- & 29.4 & $\mathrm{z}^{+}$ & 30.0 & 25.5 & $\mathrm{z}^{+}$ & 18.2 \\
\hline 54 & Sellaphora laevissima & (Kützing) Mann, 1989 & SELAELAE & 2.5 & $\mathrm{z}-$ & $46.8 *$ & 6.6 & z- & $40.2 *$ & 2.4 & $\mathrm{z}-$ & $37.8^{*}$ \\
\hline 55 & Sellaphora stroemii & (Hustedt) Kobayasi et al., 2002 & SESTOSTO & --- & --- & --- & 0.3 & z- & $52.7^{*}$ & 6.1 & $\mathrm{z}-$ & $26.6^{*}$ \\
\hline 56 & Seminavis eulenstenii & (Grunow) Danielidis et al., 2003 & SMEULEUL & 37.1 & $\mathrm{z}^{+}$ & $66.1 *$ & 27.6 & $\mathrm{z}^{+}$ & $39.9 *$ & 36.3 & $\mathrm{z}^{+}$ & $55.1 *$ \\
\hline 57 & Seminavis pusilla & (Grunow) Cox \& Reid, 2004 & SMPUSPUS & 5.0 & $\mathrm{z}^{+}$ & $74.2 *$ & 2.3 & $\mathrm{z}^{+}$ & $83.1 *$ & 3.1 & $\mathrm{z}^{+}$ & $74.4 *$ \\
\hline 58 & Seminavis witkowskii & Wachnicka \& Gaiser, 2007 & SMWITWIT & 28.5 & $\mathrm{z}^{+}$ & $90.8^{*}$ & 27.6 & $\mathrm{z}^{+}$ & $74.2^{*}$ & 30.7 & $\mathrm{z}^{+}$ & $85.0^{*}$ \\
\hline 59 & Stauroneis phoenicentron & (Nitzsch) Ehrenberg, 1843 & STPHOPHO & --- & --- & --- & --- & --- & --- & 46.9 & $\mathrm{z}^{+}$ & 15.7 \\
\hline \multirow[t]{5}{*}{60} & Synedra filiformis exilis & Cleve, 1939 & SYFILEXI & 43.3 & $\mathrm{z}^{+}$ & $71.5^{*}$ & 22.8 & $\mathrm{z}^{+}$ & $68.9 *$ & 29.4 & $\mathrm{z}^{+}$ & $59.0^{*}$ \\
\hline & & & sumz- & 2.5 & & & 2.3 & & & 2.0 & & \\
\hline & & & sumz+ + & 30.7 & & & 16.9 & & & 19.5 & & \\
\hline & & & fsumz- & 2.8 & & & 2.3 & & & 2.4 & & \\
\hline & & & fsumz + & 30.7 & & & 16.9 & & & 19.5 & & \\
\hline
\end{tabular}


Table 2-2. Species list including authority, taxon codes, and Threshold Indicator Taxa Analysis derived environmental change points $(\mathrm{CP})$, indicator values (IndVal), and response direction (declining $=\mathrm{z}-$; increasing $=\mathrm{z}^{+}$) for periphyton total phosporus in the dry, wet, and overall (both seasons combined). Sum(z) scores represent assemblage level CP using all taxa and fsum(z) scores are filtered for pure and reliable taxa only. An asterisk next to the Indval denotes pure and reliable indicator taxa ( $>0.95)$ (see taxa plots in Figures 6 and 7).

\begin{tabular}{|c|c|c|c|c|c|c|c|c|c|c|c|c|}
\hline \multirow[b]{2}{*}{ No. } & \multirow[b]{2}{*}{ Species } & \multirow[b]{2}{*}{ Authority } & \multirow[b]{2}{*}{ Code } & \multicolumn{3}{|c|}{ Dry } & \multicolumn{3}{|c|}{ Wet } & \multicolumn{3}{|c|}{ Overall } \\
\hline & & & & $\begin{array}{l}\text { TP CP } \\
(\mu \mathrm{g} / \mathrm{g})\end{array}$ & $+/$ - taxa & $\begin{array}{c}\text { IndVal } \\
(\%)\end{array}$ & $\begin{array}{l}\text { ТP CP } \\
(\mu \mathrm{g} / \mathrm{g})\end{array}$ & $+/$ - taxa & $\begin{array}{c}\text { IndVal } \\
(\%)\end{array}$ & $\begin{array}{l}\text { TP CP } \\
(\mu \mathrm{g} / \mathrm{g})\end{array}$ & $+/-\operatorname{taxa}$ & $\begin{array}{c}\text { IndVal } \\
(\%)\end{array}$ \\
\hline 1 & Achnanthes amoena & Hustedt, 1952 & ACAMOAMO & 55.8 & $z-$ & 8.49 & --- & --- & --- & 367.5 & $\mathrm{z}^{+}$ & 9.10 \\
\hline 2 & Amphora acutiuscula & Kützing, 1844 & AMACUACU & 45.1 & $\mathrm{z}-$ & 17.8 & 364.8 & $\mathrm{z}^{+}$ & 16.4 & 299.6 & $\mathrm{z}^{+}$ & 12.2 \\
\hline 3 & Amphora coffeaeformis aponina & Archibald \& Schoeman, 1984 & AMCOFAPO & --- & --- & --- & 62.4 & $z-$ & 11.8 & 63.5 & $\mathrm{z}-$ & 6.0 \\
\hline 4 & Amphora punctata & & AMPUNPUN & 89.1 & z- & 14.4 & 353.5 & $\mathrm{z}^{+}$ & 30.6 & 364.8 & $\mathrm{z}^{+}$ & 18.5 \\
\hline 5 & Amphora sulcata & Brébisson, 1854 & AMSULSUL & 196.0 & $\mathrm{z}^{+}$ & 43.3 & 193.6 & $\mathrm{z}^{+}$ & 51.5 & 193.6 & $\mathrm{z}^{+}$ & 47.3 \\
\hline 6 & Amphora veneta & Kützing, 1844 & AMVMSP01 & 59.5 & $z-$ & 21.7 & 416.9 & $\mathrm{z}^{+}$ & 28.1 & 58.8 & $\mathrm{z}-$ & 15.1 \\
\hline $7 E$ & Brachysira aponina & Kützing, 1836 & BRAPOAPO & 59.5 & $z-$ & 16.8 & 76.7 & $z-$ & 11.2 & 61.6 & $\mathrm{z}-$ & 12.4 \\
\hline 8 & Brachysira cf. aponina & Kützing, 1836 & BRCFAPO & --- & --- & --- & 49.9 & $\mathrm{z}^{+}$ & 22.0 & 49.9 & $\mathrm{z}^{+}$ & 10.3 \\
\hline 9 & Brachysira microcephela & (Grunow) Compère, 1986 & BRMICMIC & 465.5 & $z-$ & 75.7 & 214.7 & $\mathrm{z}-$ & 59.2 & 364.8 & $z^{-}$ & 66.5 \\
\hline 10 & Caponea caribbea & Podzorski, 1984 & CPCARCAR & 116.7 & $\mathrm{z}-$ & 43.9 & 37.4 & $\mathrm{z}^{+}$ & 50.0 & 142.0 & $\mathrm{z}-$ & 36.6 \\
\hline $11 c$ & Cyclotella distinguenda & Hustedt, 1927 & CYSTRSTR & 59.5 & z- & 23.7 & 63.8 & $\mathrm{z}-$ & 16.5 & 58.8 & z- & $19.7^{*}$ \\
\hline 12 & Cyclotella meneghiniania & Kützing ,1844 & STMENMEN & 89.1 & $\mathrm{z}-$ & 41.1 & 39.4 & $\mathrm{z}^{+}$ & 59.9 & 41.1 & $\mathrm{z}^{+}$ & 53.7 \\
\hline $13 Z$ & Diploneis oblongella & (Nägeli ex Kützing) Cleve-Euler, 1922 & DIOBLOBL & 265.0 & $\mathrm{z}^{+}$ & 60.4 & 364.8 & $\mathrm{z}^{+}$ & 59.9 & 265.0 & $\mathrm{z}^{+}$ & 53.5 \\
\hline $14 \mid t$ & Diploneis parma & Cleve, 1891 & DIPARPAR & 67.7 & z- & 50.9 & 61.1 & z- & $55.2 *$ & 67.6 & $\mathrm{z}-$ & $50.4^{*}$ \\
\hline $15 L$ & Diploneis vmsp1 & & DIPVMSP01 & --- & --- & --- & 46.3 & $\mathrm{z}^{+}$ & 22.2 & 45.9 & $\mathrm{z}^{+}$ & 10.3 \\
\hline $16 E$ & Encyonema evergladianum & Krammer, 1997 & ENEVEEVE & 265.0 & z- & $74.3^{*}$ & 313.0 & z- & $79.3 *$ & 364.8 & $\mathrm{z-}$ & $76.7^{*}$ \\
\hline $17 E$ & Encyonema mesianum & (Cholnoky) D.G.Mann, 1990 & ENMESMES & 48.8 & $\mathrm{z}-$ & $67.5^{*}$ & 45.3 & $\mathrm{z}-$ & $60.4^{*}$ & 50.2 & $\mathrm{z}-$ & $54.3^{*}$ \\
\hline $18 E$ & Encyonema silesiacum elegans & Krammer, 1997 & ENSILELE & 123.3 & $\mathrm{z}-$ & 12.5 & 44.1 & z- & 38.2 & 44.5 & $\mathrm{z}-$ & 26.4 \\
\hline $19 E$ & Encyonema sjsp03 & & ENSJSP03 & 48.3 & $z-$ & $43.0^{*}$ & 70.7 & $z-$ & 27.2 & 46.8 & $\mathrm{z}-$ & $33.4 *$ \\
\hline $20 E$ & Encyonopsis microcephela & (Grunow) Krammer, 1997 & ECMICMIC & 381.9 & $\mathrm{z}^{+}$ & 45.0 & 172.7 & $\mathrm{z}-$ & 36.0 & 178.0 & $\mathrm{z}-$ & 32.4 \\
\hline $21 E$ & Envekadea metezeltinii & Lee et al., 2013 & EVMETMET & 89.1 & $z-$ & 23.9 & 353.5 & $\mathrm{z}^{+}$ & 47.4 & 353.5 & $\mathrm{z}^{+}$ & 26.5 \\
\hline $22 E$ & Envekadea vanlandinghamii & Graeff, 2013 & EVVANVAN & 83.4 & $\mathrm{z}^{+}$ & 18.6 & 62.4 & $\mathrm{z}^{+}$ & 30.0 & 62.6 & $\mathrm{z}^{+}$ & 20.9 \\
\hline $23 H$ & Fragilaria ftsp 16 & & FAFTSP16 & 437.8 & $\mathrm{z}^{+}$ & 71.0 & 353.5 & $\mathrm{z}^{+}$ & $90.5^{*}$ & 353.5 & $\mathrm{z}^{+}$ & $77.4^{*}$ \\
\hline $24 \mid F$ & Fragilaria minuscula & (Grunow) Williams, 1987 & FAMINMIN & 303.7 & $\mathrm{z}^{+}$ & 35.4 & 416.9 & $\mathrm{z}^{+}$ & $65.1 *$ & 303.7 & $\mathrm{z}^{+}$ & $38.5^{*}$ \\
\hline $25 F$ & Fragilaria nanana & Lange-Bertalot, 1993 & FANANNAN & 50.7 & $z-$ & 9.0 & 35.4 & $\mathrm{z}^{+}$ & 12.7 & 34.9 & $\mathrm{z}^{+}$ & 10.5 \\
\hline 26 & Fragilaria synegrotesca & Lange-Bertalot, 1993 & FASYNSYN & 142.0 & $\mathrm{z}^{+}$ & $85.0^{*}$ & 193.6 & $\mathrm{z}^{+}$ & $89.9^{*}$ & 193.6 & $\mathrm{z}^{+}$ & $88.3^{*}$ \\
\hline $27 \mathrm{C}$ & Gomphonema intricatum vibrio & (Ehrenberg) Cleve, 1894 & GOINTVIB & 437.8 & $\mathrm{z}^{+}$ & 48.5 & 416.9 & $\mathrm{z}^{+}$ & 70.3 & 406.0 & $\mathrm{z}^{+}$ & $54.1 *$ \\
\hline & Kobayasiella parasubtilissima & Lange-Bertalot, 1999 & KOPARPAR & 65.5 & $\mathrm{z}^{+}$ & 12.7 & --- & --- & --- & 142.0 & $\mathrm{z}^{+}$ & 9.1 \\
\hline
\end{tabular}




\begin{tabular}{|c|c|c|c|c|c|c|c|c|c|c|c|c|}
\hline 29 & Kobayasiella subtilissima & Lange-Bertalot, 1999 & KOSUBSUB & 299.6 & $\mathrm{z}^{+}$ & 34.4 & --- & --- & --- & 299.6 & $\mathrm{z}^{+}$ & 31.9 \\
\hline 30 & Mastogloia asperuloides & Hustedt, 1933 & MAASPASP & 59.5 & $z^{-}$ & 13.0 & 83.3 & $\mathrm{z}-$ & 16.3 & 79.8 & $\mathrm{z}-$ & $12.8^{*}$ \\
\hline 31 & Mastogloia braunii & Grunow, 1863 & MABRABRA & 92.0 & $\mathrm{z}-$ & 15.3 & 364.8 & $\mathrm{z}^{+}$ & 19.9 & 364.8 & $\mathrm{z}^{+}$ & 13.1 \\
\hline 32 & Mastogloia calcarea & Lee et al., 2014 & MACALCAL & 339.2 & $z^{+}$ & 71.0 & 193.6 & $\mathrm{z}^{+}$ & 71.1 & 285.1 & $\mathrm{z}^{+}$ & $70.3^{*}$ \\
\hline 33 & Mastogloia lanceolata & Thwaites ex W.Smith, 1856 & MALANLAN & 239.5 & $\mathrm{z}^{+}$ & 49.9 & 353.5 & $\mathrm{z}^{+}$ & $87.7^{*}$ & 178.0 & $\mathrm{z}^{+}$ & $59.6^{*}$ \\
\hline 34 & Mastogloia pseduosmithii & Lee et al., 2014 & MAPSEPSE & 406.0 & $\mathrm{z}^{+}$ & 52.9 & 353.5 & $\mathrm{z}^{+}$ & 44.3 & 406.0 & $\mathrm{z}^{+}$ & $47.4 *$ \\
\hline 35 & Navicula bulnheimii & Grunow, 1880 & NABULBUL & --- & --- & --- & 67.4 & $\mathrm{z}-$ & 28.3 & 82.2 & z- & $15.4 *$ \\
\hline 36 & Navicula cryptotenella & Lange-Bertalot, 1985 & NACRYCRY & 67.7 & $\mathrm{z}-$ & $54.4^{*}$ & 172.7 & $\mathrm{z}-$ & 32.6 & 73.1 & $\mathrm{z}-$ & $35.5^{*}$ \\
\hline 37 & Navicula duerrenbergiana & Hustedt, 1934 & NADUEDUE & --- & --- & --- & 103.8 & $z-$ & 19.6 & 79.8 & $\mathrm{z}-$ & $12.5^{*}$ \\
\hline 38 & Navicula lenzii & Hustedt, 1950 & NALENLEN & --- & --- & --- & 90.4 & $\mathrm{z}-$ & 21.7 & 79.8 & $\mathrm{z}-$ & 14.0 \\
\hline 39 & Navicula radiosa & Kützing, 1844 & NARADRAD & 92.2 & $z^{-}$ & 24.8 & 72.5 & $\mathrm{z}^{+}$ & 21.9 & 406.0 & $z-$ & 21.5 \\
\hline 40 & Navicula salinarum & Grunow, 1880 & NASALSAL & 59.5 & $z^{-}$ & 18.9 & 113.0 & $\mathrm{z}-$ & 24.5 & 63.8 & $\mathrm{z}-$ & $20.7 *$ \\
\hline 41 & Navicula salinicola & Hustedt, 1939 & NASAISAI & 60.9 & $\mathrm{z}-$ & 21.0 & 416.9 & $\mathrm{z}^{+}$ & 27.5 & 64.6 & $\mathrm{z}-$ & 15.7 \\
\hline 42 & Nitzschia acicularis & (Kützing) W.Smith, 1853 & NIACIACI & --- & --- & --- & 72.0 & $\mathrm{z}-$ & 20.8 & 74.0 & $\mathrm{z}-$ & 10.8 \\
\hline 43 & Nitzschia ftsp16 & & NIFTSP16 & 233.6 & $\mathrm{z}^{+}$ & 54.5 & 103.8 & $\mathrm{z}^{+}$ & $60.5^{*}$ & 236.9 & $\mathrm{z}^{+}$ & $58.1^{*}$ \\
\hline 44 & Nitzschia microcephela & Grunow, 1880 & NIMICMIC & 152.8 & $z^{-}$ & 16.4 & 193.6 & $\mathrm{z}-$ & 31.5 & 211.5 & $z^{-}$ & 23.7 \\
\hline 45 & Nitzschia cf. microcephela & Grunow, 1880 & NICFMICMIC & --- & --- & --- & 103.8 & $\mathrm{z}-$ & 13.0 & 102.6 & $\mathrm{z}-$ & 7.7 \\
\hline 46 & Nitzschia nana & Grunow, 1881 & NINANNAN & 289.0 & $\mathrm{z}^{+}$ & $65.3^{*}$ & 475.5 & $\mathrm{z}^{+}$ & $70.2^{*}$ & 406.0 & $\mathrm{z}^{+}$ & $70.1^{*}$ \\
\hline 47 & Nitzschia palea debilis & (Kützing) Grunow, 1880 & NIPALDEB & 437.8 & $z-$ & 84.2 & 313.0 & $\mathrm{z}-$ & $75.8^{*}$ & 303.7 & z- & $73.1^{*}$ \\
\hline 48 & Nitzschia cf scalaris & (Ehrenberg) Smith, 1853 & NISCASCA & 39.4 & $\mathrm{z}-$ & 14.2 & --- & --- & --- & 40.9 & $\mathrm{z}-$ & 5.5 \\
\hline 49 & Nitzschia serpentiraphe & Lange-Bertalot, 1993 & NISERSER & 233.6 & $\mathrm{z}^{-}$ & $52.4^{*}$ & 35.4 & $\mathrm{z}-$ & $69.9 *$ & 236.9 & $z^{-}$ & $48.5^{*}$ \\
\hline 50 & Parlibellus panduriformis & John, 1991 & PAPANPAN & 37.7 & $\mathrm{z}-$ & 16.3 & --- & --- & --- & 58.8 & $\mathrm{z}-$ & 9.6 \\
\hline 51 & Pinnularia major & (Kützing) Rabenhorst, 1853 & PINVIRVIR & 465.5 & $\mathrm{z}^{+}$ & 18.6 & 313.0 & $\mathrm{z}^{+}$ & 21.3 & 564.6 & $\mathrm{z}^{+}$ & 37.1 \\
\hline 52 & Pleurosigma salinarum & (Grunow) Grunow, 1880 & PLSALSAL & --- & --- & --- & 416.9 & $\mathrm{z}^{+}$ & 13.5 & 430.5 & $\mathrm{z}^{+}$ & 6.8 \\
\hline 53 & Pleurosira vmsp1 & & PEVMSP01 & --- & --- & --- & 83.3 & $\mathrm{z}-$ & 7.0 & 79.8 & $\mathrm{z-}$ & 3.9 \\
\hline 54 & Sellaphora laevissima & (Kützing) Mann, 1989 & SELAELAE & 49.6 & $\mathrm{z-}$ & $51.6^{*}$ & 44.1 & $\mathrm{z}-$ & $57.7^{*}$ & 69.3 & $\mathrm{z-}$ & $41.9 *$ \\
\hline 55 & Sellaphora stroemii & (Hustedt) Kobayasi et al., 2002 & SESTOSTO & 37.4 & $\mathrm{z}-$ & 16.4 & 46.3 & $\mathrm{z}-$ & $57.0^{*}$ & 46.9 & $\mathrm{z}-$ & $35.1 *$ \\
\hline 56 & Seminavis eulenstenii & (Grunow) Danielidis et al., 2003 & SMEULEUL & 89.1 & $\mathrm{z}-$ & 14.2 & 83.3 & $\mathrm{z}-$ & 17.7 & 92.2 & $\mathrm{z}-$ & 15.4 \\
\hline 57 & Seminavis pusilla & (Grunow) Cox \& Reid, 2004 & SMPUSPUS & 239.5 & $\mathrm{z}^{+}$ & 54.4 & 193.6 & $\mathrm{z}^{+}$ & $73.5^{*}$ & 245.3 & $\mathrm{z}^{+}$ & $62.4 *$ \\
\hline 58 & Seminavis witkowskii & Wachnicka \& Gaiser, 2007 & SMWITWIT & 45.1 & $\mathrm{z}-$ & 30.9 & 62.4 & $\mathrm{z}^{+}$ & 20.2 & 87.3 & $\mathrm{z}-$ & 20.5 \\
\hline 59 & Stauroneis phoenicentron & (Nitzsch) Ehrenberg, 1843 & STPHOPHO & 67.7 & $\mathrm{z}-$ & 10.3 & --- & --- & --- & 37.2 & z- & 14.0 \\
\hline \multirow[t]{5}{*}{60} & Synedra filiformis exilis & Cleve, 1939 & SYFILEXI & 265.0 & $\mathrm{z}^{+}$ & 26.8 & 49.9 & $\mathrm{z}^{+}$ & $32.0 *$ & 265.0 & $\mathrm{z}^{+}$ & 25.2 \\
\hline & & & sumz- & 59.5 & & & 193.6 & & & 81.5 & & \\
\hline & & & sumz+ + & 303.7 & & & 364.8 & & & 285.1 & & \\
\hline & & & fsumz- & 48.7 & & & 45.3 & & & 69.3 & & \\
\hline & & & fsumz + & 265.0 & & & 364.8 & & & 285.1 & & \\
\hline
\end{tabular}


Figure 2-1. Map of southeastern Florida showing the location of the 7 transects and their sites. The transitional area between freshwater and coastal wetlands is visible as a "white zone" in the satellite imagery. Yellow boxes define western and eastern transects.

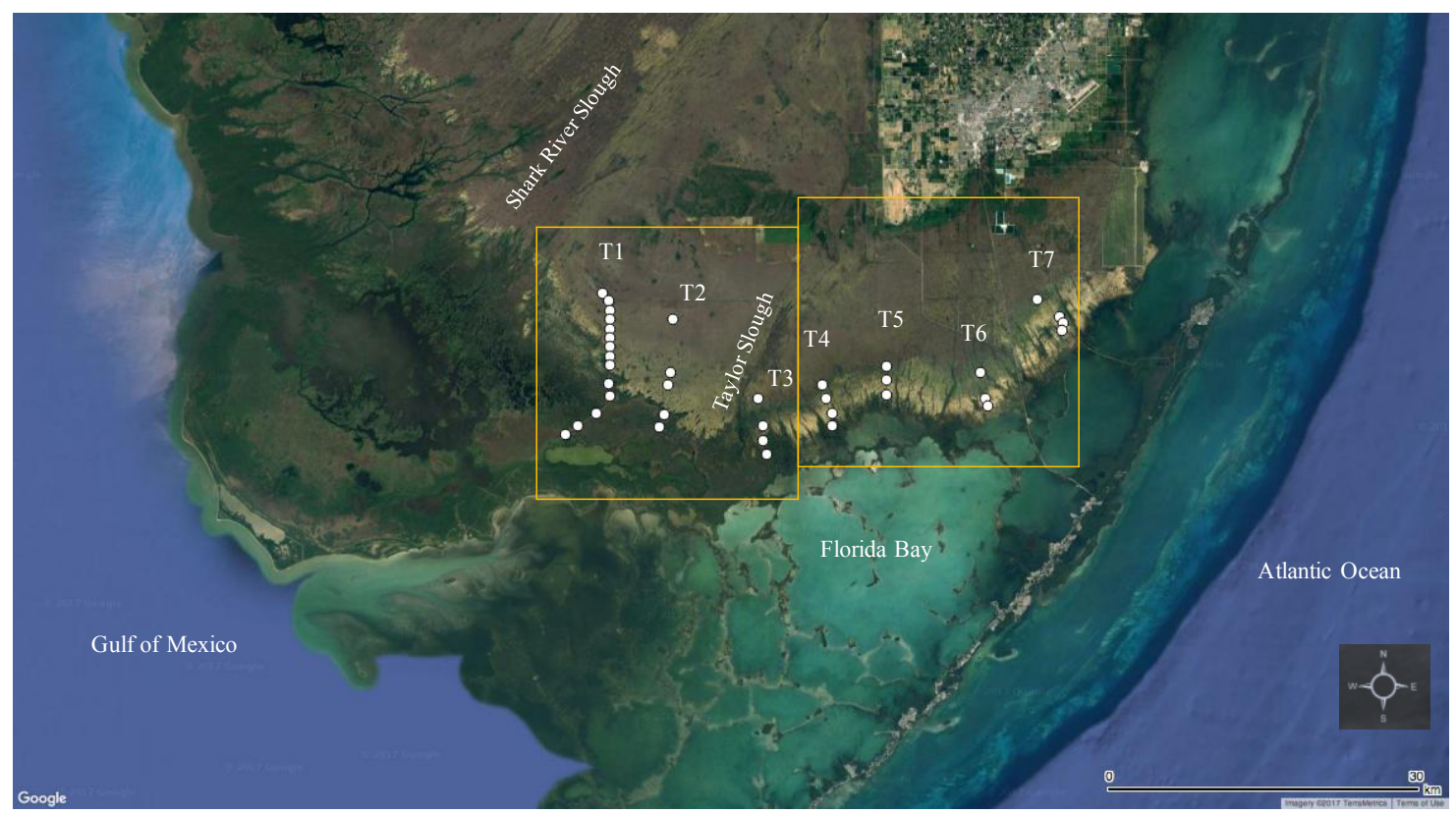


Figure 2-2. Latitudinal porewater conductivity (A) and periphyton total phosphorus (B) gradients at successive points along each transect during the dry and wet seasons averaged over 2014 and 2015 samples. Transects are separated by solid vertical lines and ordered west to east to display longitudinal gradients. The environmental gradient for each transect is plotted on the first y-axis (black lines). Grey dashed lines represent transects with successive sites along each transect on the $\mathrm{x}$-axis and their distance from the coast on the second y-axis.

A.

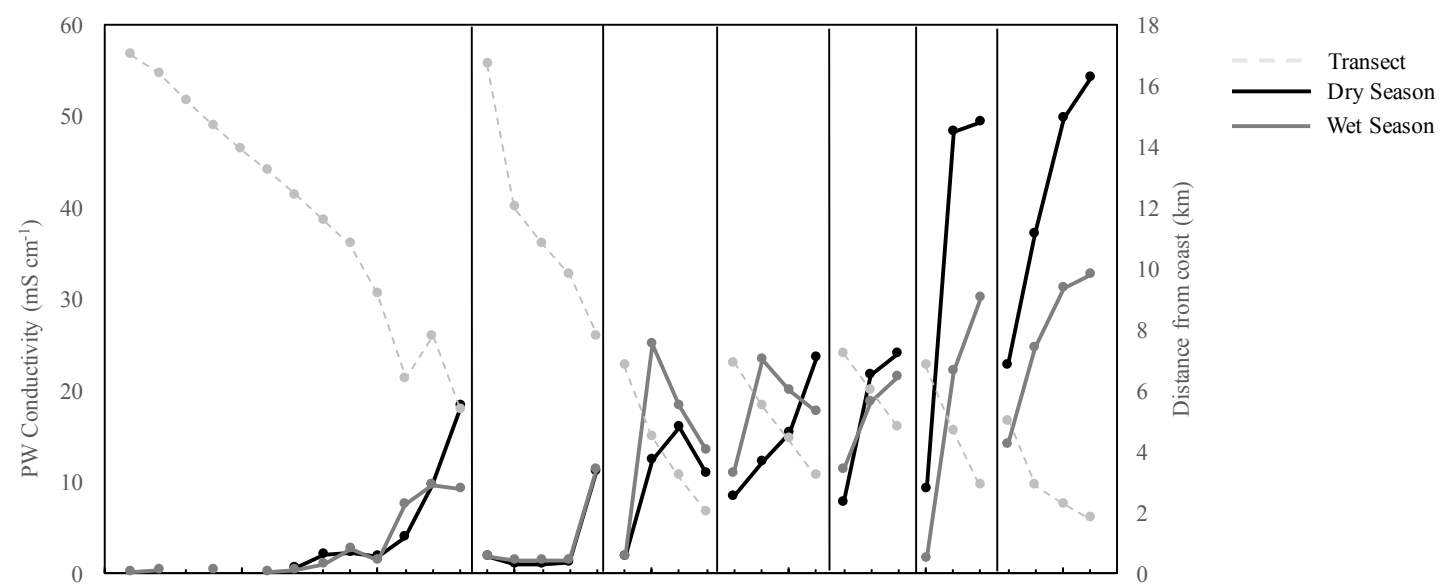

B.

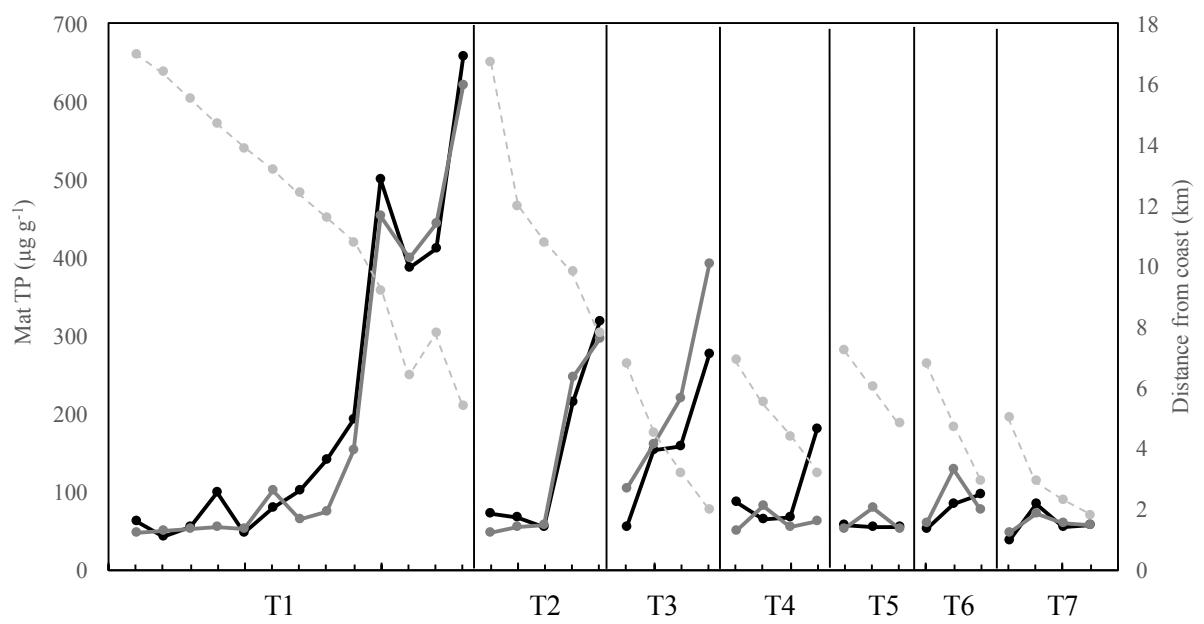


Figure 2-3. Principal coordinate analysis (PCO) ordination plots of dry (top) and wet (bottom) seasons, including 2014 and 2015 samples, showing sites grouped based on 45\% species similarity and significantly correlated environmental variables. Symbols represent the transect to which the site belongs and labels denote the distance quartile for the site $(\mathrm{NN}, \mathrm{N}, \mathrm{C}, \mathrm{S})$. The groups were designated as either freshwater, transitional, or brackish water based on the sites that fell within each cluster.

A.

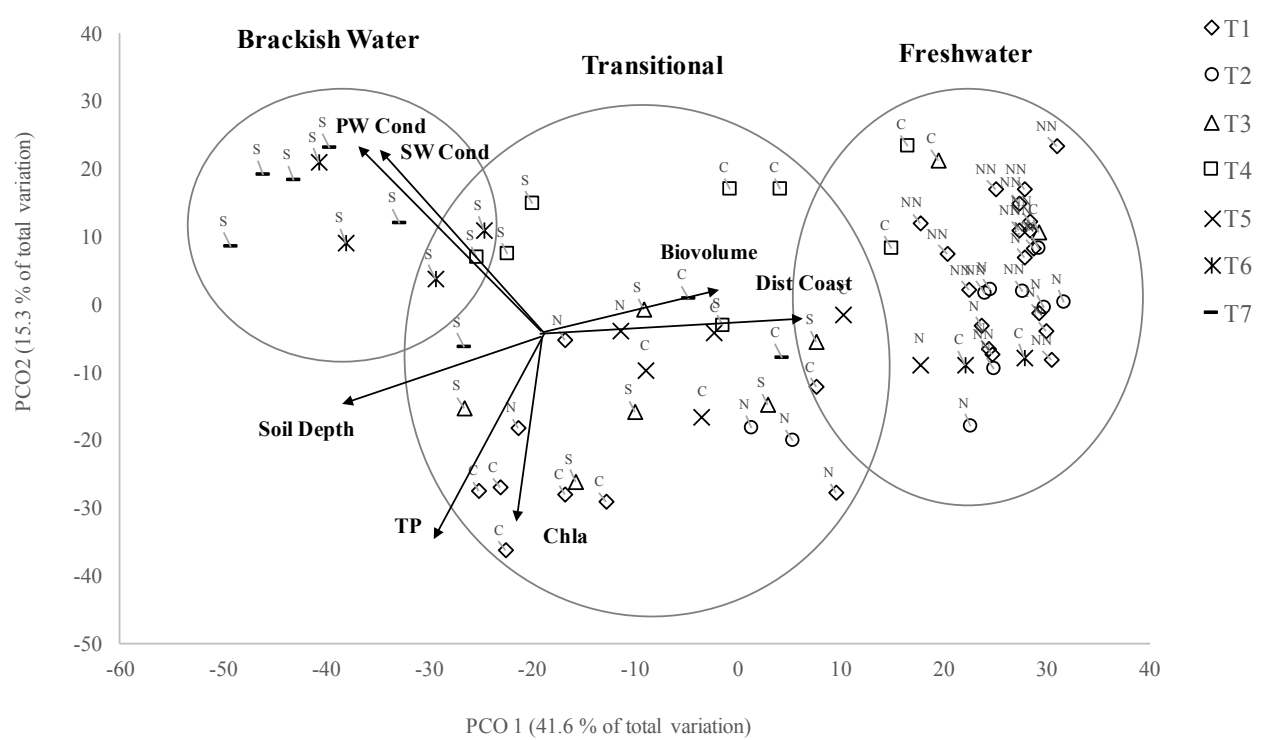

B.

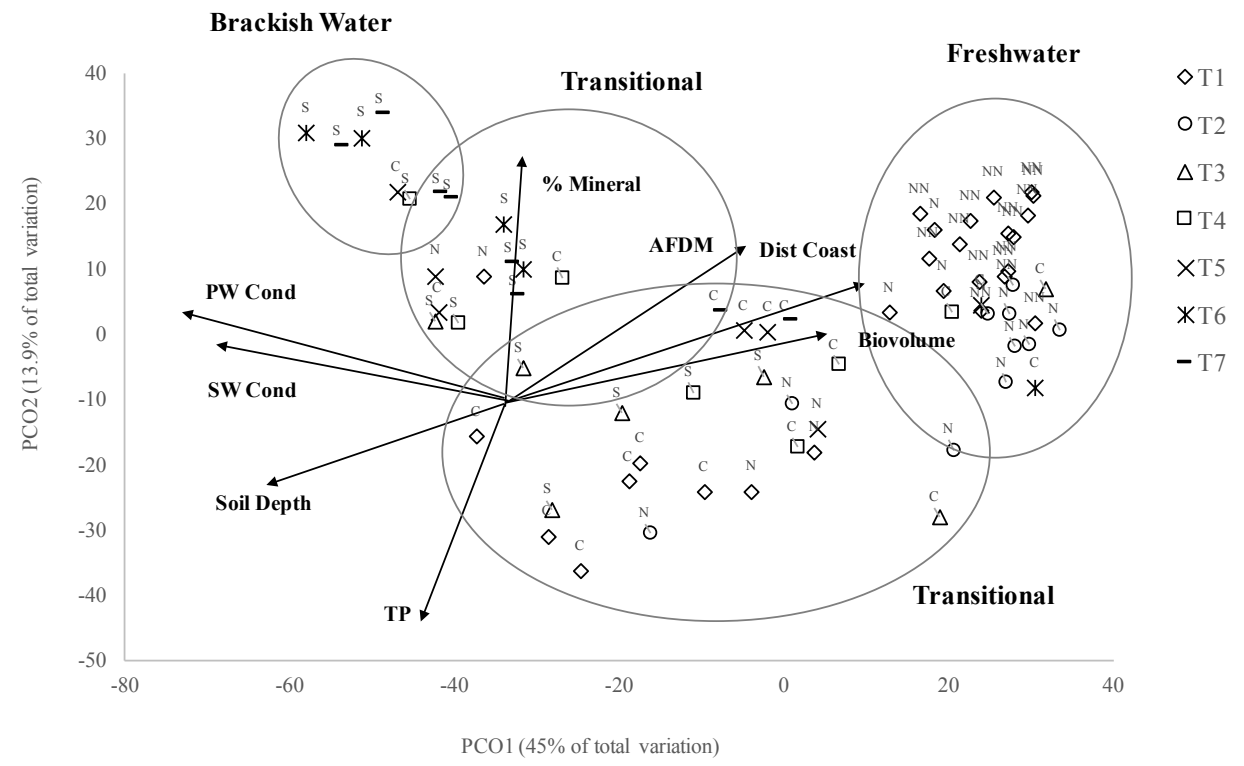


Figure 2-4. Principal coordinate analysis (PCO) axis 1 scores for successive sites along each transect during the dry (A) and wet (B) seasons. Transects are separated by solid vertical lines and ordered west to east to display longitudinal differences in the location of the ecotone. PCO axis score for sites along each transect is plotted on the first y-axis (black lines). Grey dashed lines represent transects with successive sites along each transect on the $\mathrm{x}$-axis and their distance from the coast on the second $\mathrm{y}$-axis. The location of the ecotone at each transect, determined as the vector with the greatest slope is represented by grey boxes placed on corresponding points on the transect lines.

A.

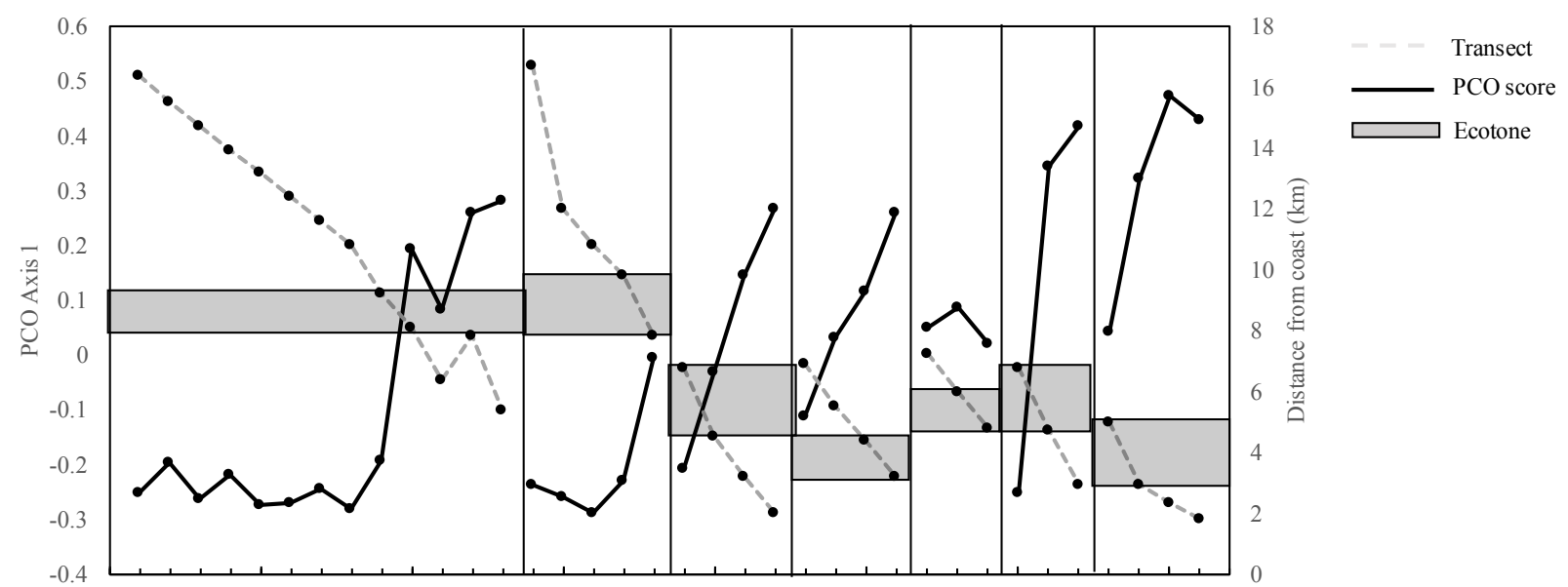

B.

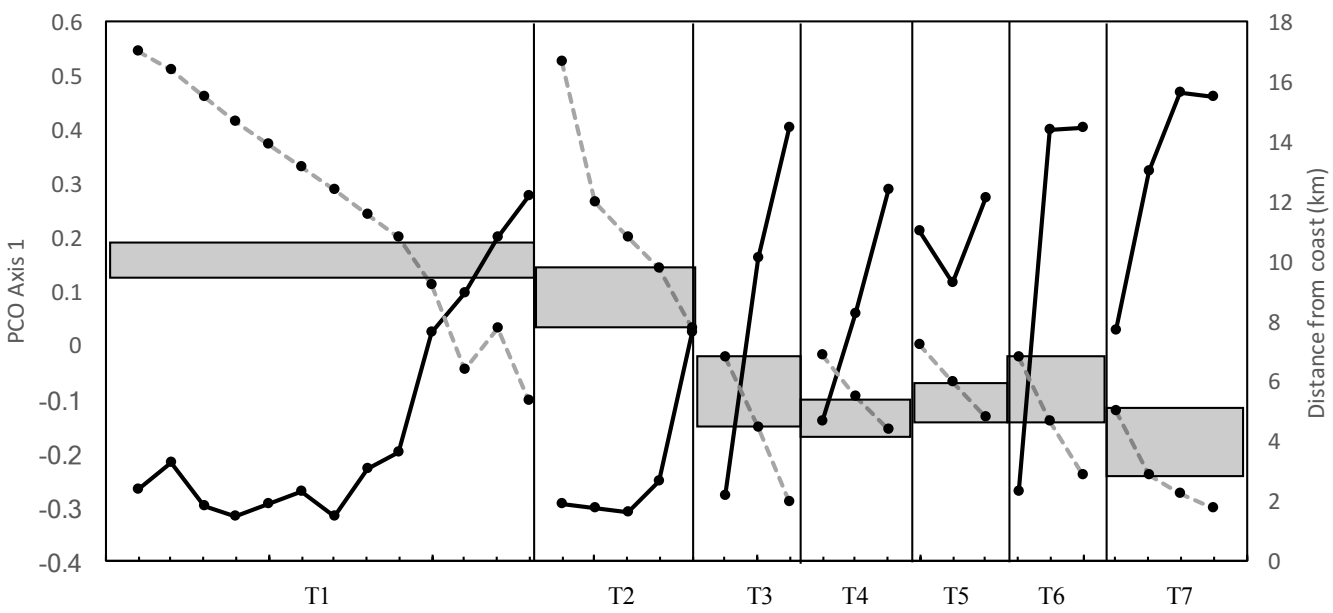


Figure 2-5. The magnitude of average porewater conductivity (A) and total phosphorus (B) at each site, averaged over all four sampling events, is represented by the size of the orange and blue circles, respectively. Pie charts show the relative abundances, also averaged over the four sampling events, of pure and reliable indicator taxa for conductivity and TP at each site. The diatom-inferred ecotone identified from principal coordinate analysis axis score plots for the dry (solid line) and wet (dashed line) are drawn on each map.

A.

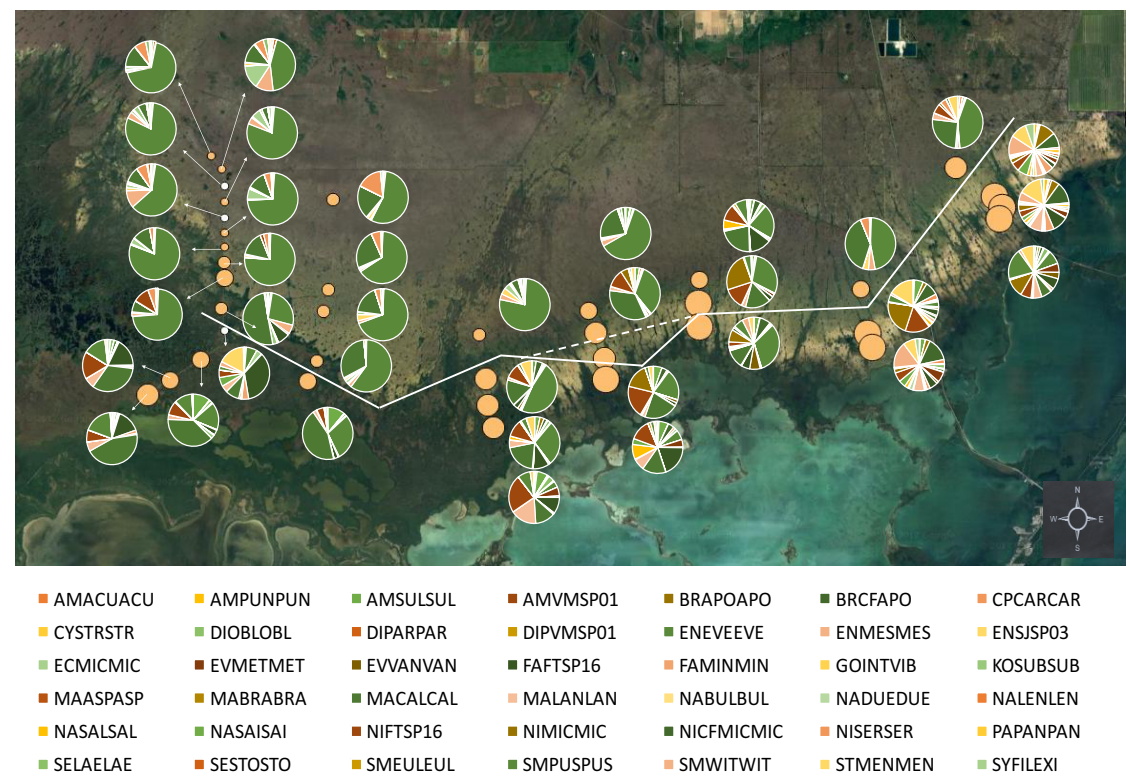

B.

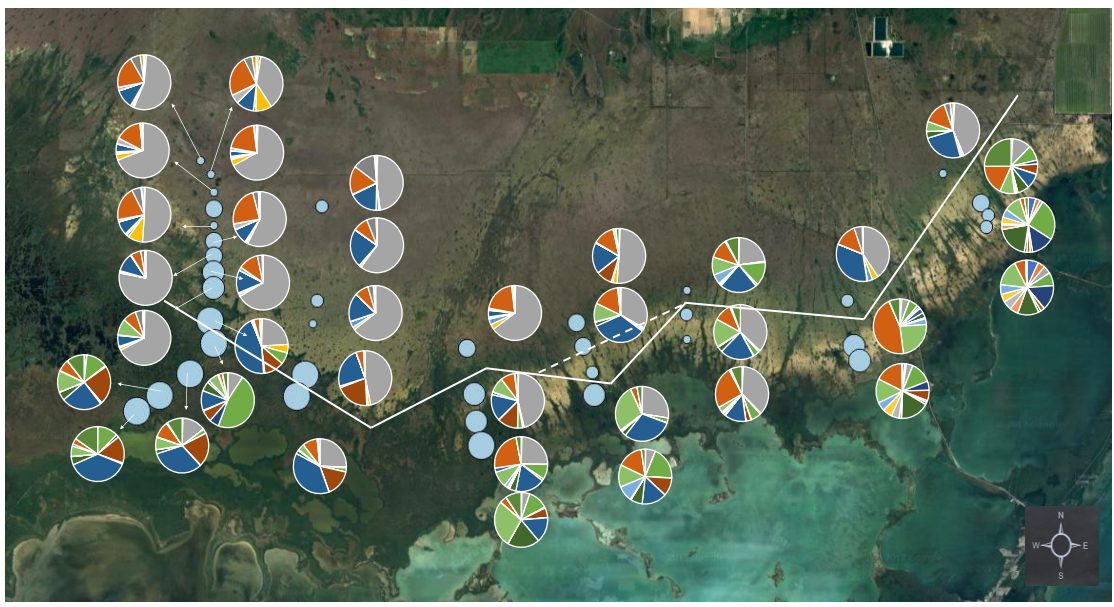

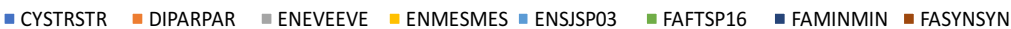

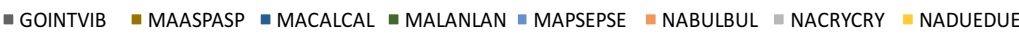

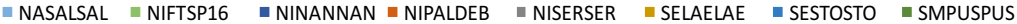


Figure 2-6. Threshold Indicator Taxa Analysis (TITAN) of periphytic diatom response to porewater (PW) conductivity gradients in the southern Everglades during the dry (A), wet (B), and overall seasons (C). Change points and their distributions $\left(5^{\text {th }}\right.$ and $95^{\text {th }}$ percentiles) of pure and reliable $(>0.95)$ indicator taxa (top). Assemblage-level response to PW conductivity where a peak in filtered $\operatorname{sum}\left(\mathrm{z}^{-}\right)$and $\operatorname{sum}\left(\mathrm{z}^{+}\right)$indicates an assemblage threshold where a coincident decline or increase in taxa occurs (bottom). Solid circles are negative taxa $(\mathrm{z}-)$; open circles are positive taxa $\left(\mathrm{z}^{+}\right)$; dotted horizontal lines on the taxa plots represent $5^{\text {th }}$ and $95^{\text {th }}$ percentiles of CPs; dotted vertical lines signify location of assemblage-level threshold. Taxa codes are defined in Table 1.
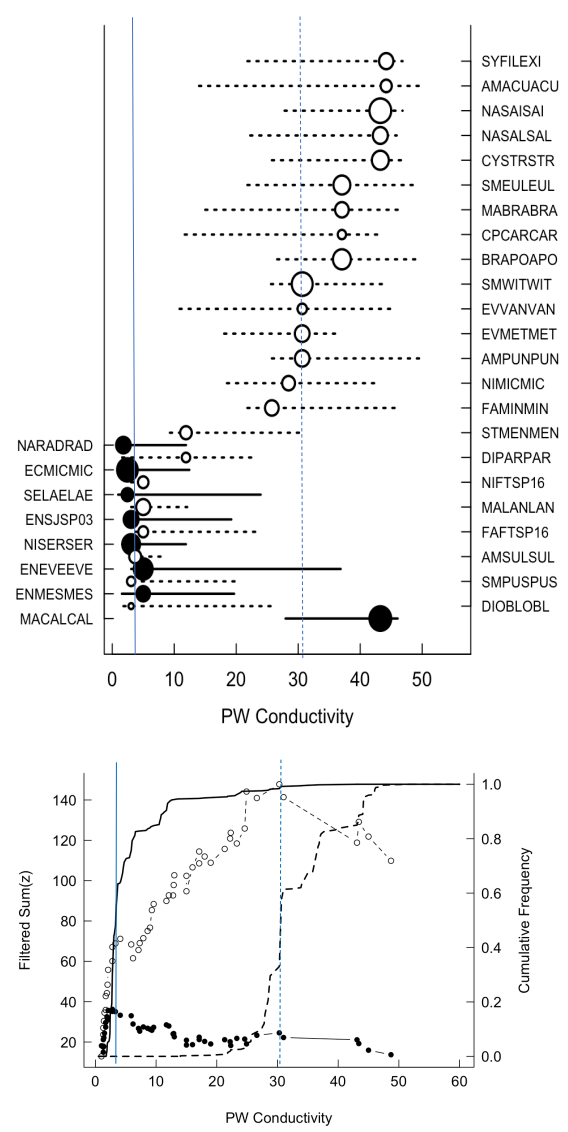

B.
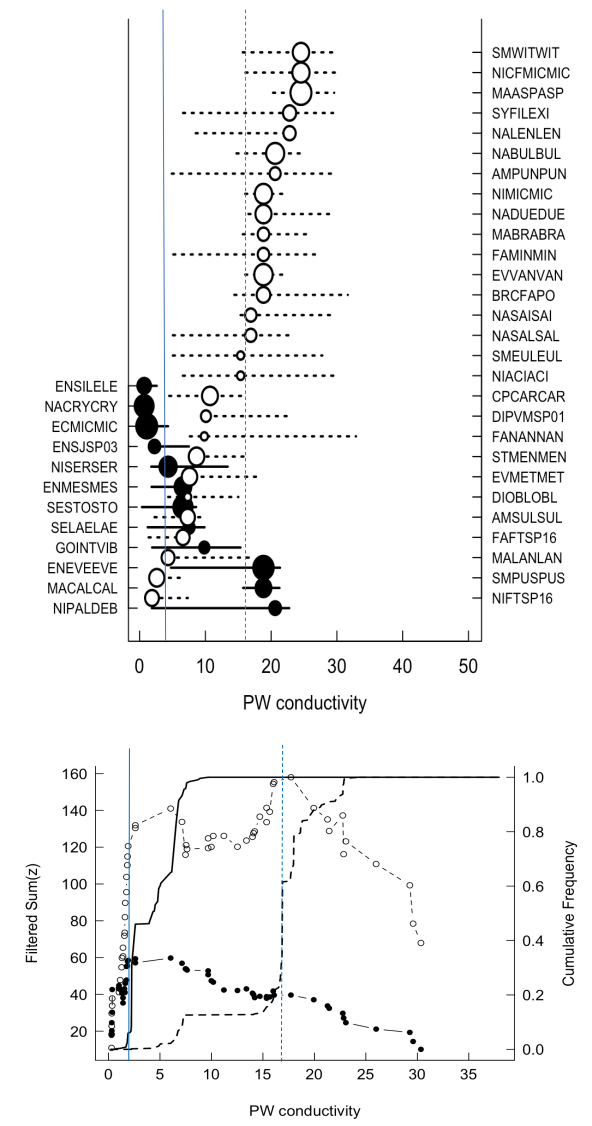

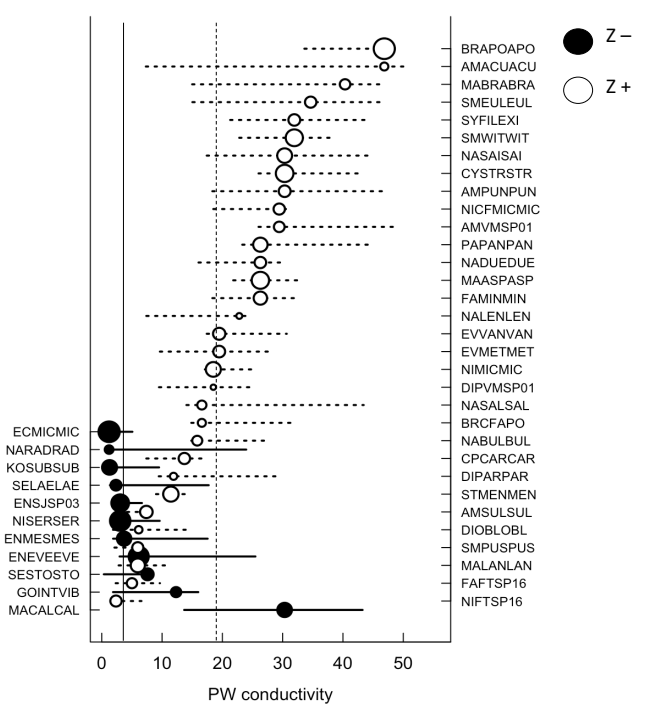


Figure 2-7. Threshold Indicator Taxa Analysis (TITAN) of periphytic diatom response to periphyton total phosphorus (TP) gradients in the southern Everglades during the dry (A), wet (B), and overall seasons (C). Change points and their distributions $\left(5^{\text {th }}\right.$ and $95^{\text {th }}$ percentiles) of pure and reliable $(>0.95)$ indicator taxa (top). Assemblage-level response to PW conductivity where a peak in filtered $\operatorname{sum}\left(\mathrm{z}^{-}\right)$and $\operatorname{sum}\left(\mathrm{z}^{+}\right)$indicates an assemblage threshold where a coincident decline or increase in taxa occurs (bottom). Solid circles are negative taxa (z-); open circles are positive taxa $\left(\mathrm{z}^{+}\right)$; dotted horizontal lines on the taxa plots represent $5^{\text {th }}$ and $95^{\text {th }}$ percentiles for CPs; dotted vertical lines signify location of assemblage-level threshold. Taxa codes are defined in Table 2.

A.
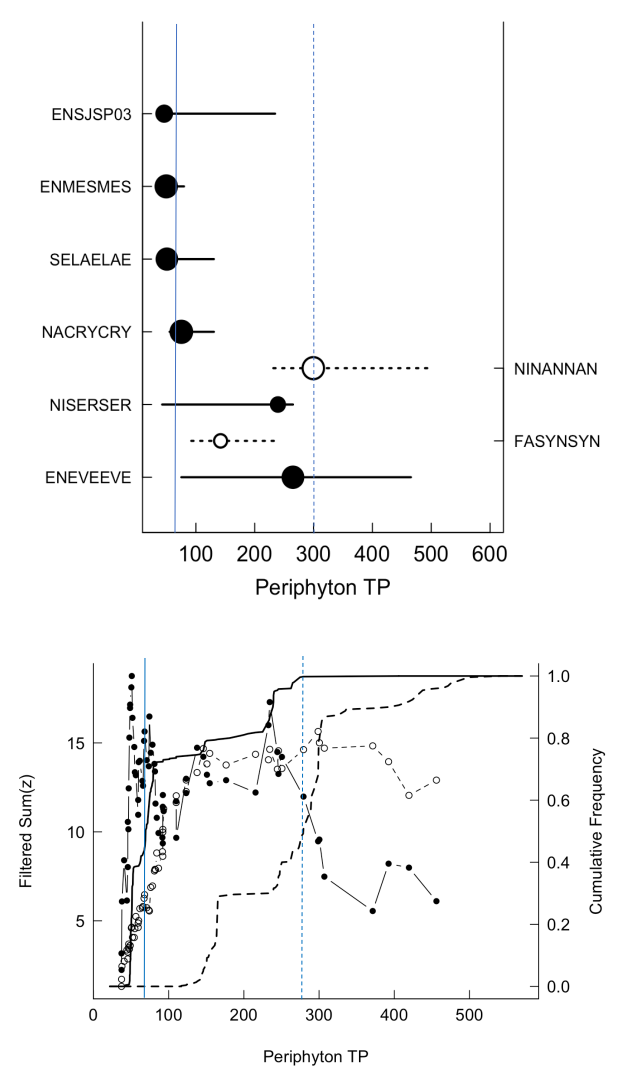
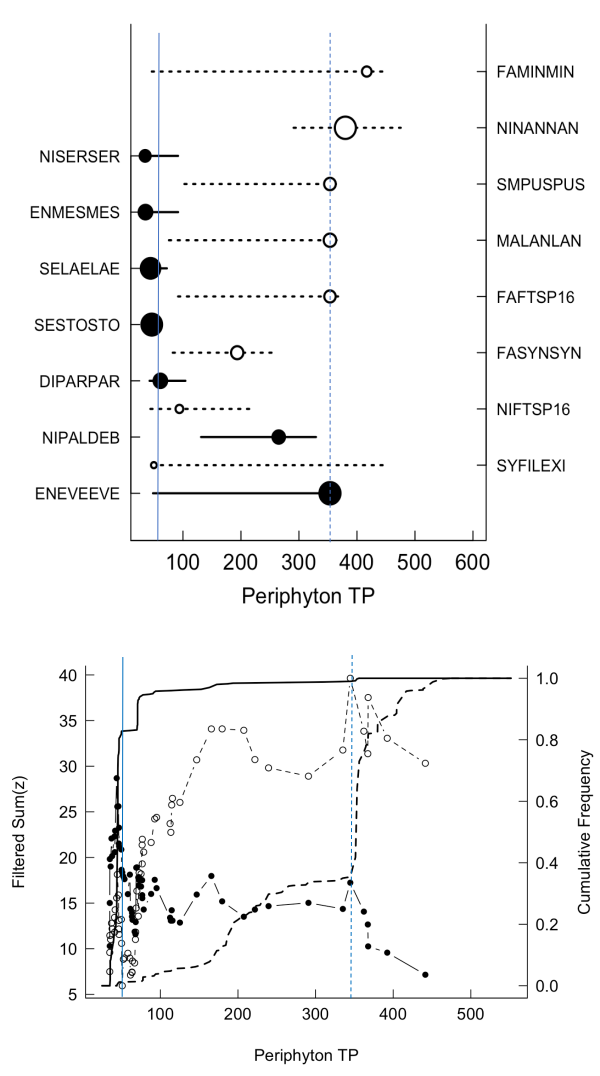

C.
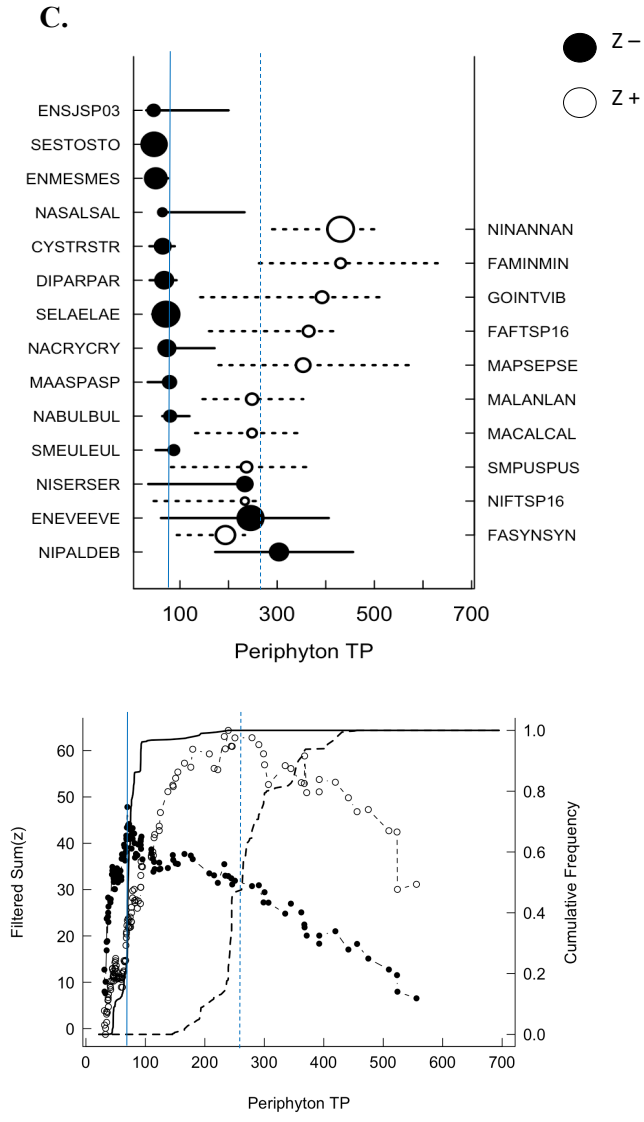


\title{
CHAPTER III
}

FUNCTIONAL AND COMPOSITIONAL RESPONSES OF PERIPHYTON MATS TO SIMULATED SALTWATER INTRUSION IN THE SOUTHERN EVERGLADES

\begin{abstract}
Periphyton plays key ecological roles in karstic, freshwater wetlands and is extremely sensitive to environmental change making it a powerful tool to gauge saltwater intrusion into these vulnerable and valuable ecosystems. We conducted a field mesocosm experiment in a freshwater and a brackish marsh in the Florida Everglades, USA to test the effects of saltwater intrusion on periphyton metabolism, nutrient content, and diatom species composition, and how these responses differ between mats from freshwater versus brackish marshes. Pulsed saltwater intrusion was simulated by dosing treatment chambers monthly with a brine solution for 15 months; control chambers were simultaneously dosed with site water. Periphyton from the freshwater marsh responded to a 1 ppt elevation in surface water salinity with reduced productivity and total carbon, nitrogen, and phosphorus content. These functional responses were accompanied by significant shifts in periphytic diatom assemblages. Periphyton mats at the brackish marsh were more functionally resilient to the saltwater treatment ( $\sim 2$ ppt above ambient), but despite the weak functional responses of brackish water periphyton to elevated salinity, significant shifts in diatom composition were detected. Our findings highlight the sensitivity of diatoms to small scale changes in salinity compared to other periphytic communities and supports the idea that diatoms are stronger indicators of small, short-term changes in salinity compared to
\end{abstract}


periphyton functional metrics. This research provides new and valuable information regarding periphyton dynamics in response to changing water sources that will allow us to extend the use of periphyton, and their diatom assemblages, as tools for environmental assessments related to saltwater intrusion in the southern Everglades and other karstic, freshwater wetlands.

\section{INTRODUCTION}

Calcareous periphyton mats are an important and abundant component of the karst, freshwater wetlands found along the coastlines of the Caribbean Basin. In these landscapes, periphyton forms thick, dense mats several centimeters deep that blanket the substrate and marsh vegetation. These mats provide a unique microhabitat for a variety of autotrophic and heterotrophic organisms and play an important role in food web dynamics, organic and inorganic carbon cycling, nutrient cycling, and marl soil (calcium carbonate mud) formation (Davis 1994, Rejmankova and Komarkova 2000, Hagerthey et al. 2011, Gaiser et al. 2011, La Hee and Gaiser 2012, Schedlbauer et al. 2012, Troxler et al. 2013, Trexler et al. 2015). Furthermore, periphyton is an excellent bioindicator and is often used in ecological assessments of the changing environmental conditions in coastal wetlands, including water quality degradation and hydrologic modification (McCormick 1998, Gaiser et al. 2009). Coastal, freshwater wetlands face the added pressure of saltwater intrusion as sea levels continue to rise and altered hydrologic regimes reduce freshwater inputs to downstream wetlands (White and Kaplan 2017). Even though periphyton communities can serve as excellent bioindicators of coastal change, little is known about 
their use in detecting novel rates of marine water intrusion into coastal, freshwater wetlands. In order to determine the utility of periphyton as an indicator of marine water intrusion, we need to understand how exposure to saltwater influences periphyton productivity, nutrient uptake, and species composition over short- and long-time scales.

Intrusion of marine water into coastal freshwater wetlands is largely driven by climate change and can be exacerbated by altered natural freshwater flows in ways that lessen inputs to coastal marshes and reduce groundwater and aquifer recharge (Briceno et al. 2014, Herbert et al. 2015). Reduced freshwater flow into downstream marshes combined with sea level rise allows marine water to intrude further inland, particularly during the dry season (December-May), exposing freshwater wetlands to elevated salinity and altered ionic concentrations (Dessu et al. 2018). For example, Saha et al. (2012) reported increased mean surface water salinity from 2 psu at the end of the wet season (November) to $14 \mathrm{psu}$ at the end of the dry season (May) at an oligohaline site in the southwestern Everglades; at the same location, Saha et al. 2011 documented mean groundwater salinity increases from 2 psu in 2003 to 12 psu in 2009. The seasonal and long-term changes in natural salinity gradients caused by saltwater intrusion in the Everglades and other coastal, freshwater wetlands affects the ecological functioning and community structure of key ecosystem components, including vegetation, soil microbes, and periphyton (Ikenaga et al. 2010, Krauss et al. 2011, Troxler et al. 2014, Mazzei and Gaiser 2018).

Periphyton is exceptionally sensitive to environmental change and responds with shifts in species composition that in turn affect the physical structure and ecological roles of these mats (Gaiser et al. 2009, Gaiser et al. 2011, Hagerthey et al. 2011). Calcareous 
periphyton mats are characterized as microbial assemblages of diatoms, cyanobacteria, chlorophytes and other microorganisms surrounded by a matrix of mucilage and interstitial calcium carbonate secreted by certain resident algal species (Azim and Asaeda 2005, Hagerthey et al. 2011). In the Florida Everglades, periphyton has been shown to respond more quickly and predictably to changes in hydrology and water quality than other wetland plant communities because of the environmental specificity and short generation times of resident taxa (McCormick et al. 1998, Gaiser et al. 2006, Gaiser 2009, Wachnicka et al. 2010, Gaiser et al. 2011, Lee et al. 2013). Diatoms are particularly sensitive to changing environmental conditions and are commonly used as bioindicators in water quality assessments (Stevenson et al. 1999, Potapova and Charles 2007, Desrosiers et al. 2013, Stevenson 2014). Diatoms are also relatively easy to identify compared to cyanobacteria and chlorophytes because of their species-specific cell wall ornamentation which can be discerned under light microscopy. Furthermore, many periphytic diatoms contribute to mat formation and cohesion through the production of extracellular mucilage and attachment structures (Johnson and Tuchman 1997, Azim and Asaeda 2005, Lee et al. 2014). Therefore, shifts in the composition and relative abundances of diatoms, and other matengineering species (e.g., cyanobacteria), will result in different periphyton mat types, such as non-calcareous biofilms or filamentous mats, that may not provide the same ecological services as the native calcareous mats found in karstic, freshwater wetlands (Vymazal et al. 1995, McCormick and O’Dell 1996, Pan et al. 2000, Rejmankova and Komarkova 2005, Gaiser et al. 2006, Hagerthey et al. 2011, Gaiser et al. 2011).

The response of calcareous periphyton to changes in nutrient availability, particularly phosphorus, and modified hydroperiod has been well documented in the 
Florida Everglades (Gaiser et al. 2006, Hagerthey et al. 2011, Sola et al. 2018); however, not much is known about how these mats respond to the increased salinity and changes in water chemistry caused by saltwater intrusion. Exposure of aquatic plants and algae to elevated salinity can lead to osmotic stress, ion toxicity, and nutrient uptake limitations (Alam 1999, Mendelssohn et al. 2006, Touchette 2007). Osmotic stress causes loss of turgor pressure and water deficits in plant and algal cells due to diffusion of water out of cells during hyperosmotic conditions that can eventually result in cell death (Hasegawa et al. 2000). Furthermore, exposure to saltwater disrupts cellular ion homeostasis. The accumulation of sodium ions has been shown to decrease chlorophyll content, photosynthetic electron transport activities, and the uptake of essential nutrients in nonsalt-adapted autotrophs (( $\mathrm{Lu}$ and Vonshak 2002, Sudhir and Murthy 2004, Hu and Schmidhalter 2005). Therefore, the physiological stressors imposed by saltwater intrusion on the periphytic algal communities native to freshwater, karstic wetlands have the potential to alter their productivity, nutrient uptake capacity, and species composition as freshwater populations decline in response to salt stress and salt-tolerant species from adjacent coastal waters gain a competitive advantage.

Diatom assemblage turnover along natural salinity gradients has been well documented in Caribbean karstic wetlands (Gaiser et al. 2005, Wachnicka et al. 2010, La Hee and Gaiser 2012, Nodine and Gaiser 2014, Mazzei and Gaiser in press); however, the effect of elevated salinity on periphyton functional processes and species composition has not been explicitly tested. In this study, in situ mesocosm experiments were used to test the effects of exposure to pulses of saltwater on periphyton metabolism (net ecosystem productivity, ecosystem respiration, and gross primary productivity), nutrient content (total 
carbon, nitrogen, and phosphorus), and diatom species composition in a freshwater (FW) and brackish (BW) marsh. We hypothesized that exposure to artificial seawater would reduce periphyton productivity, total carbon content, and nutrient uptake due to the osmotic and ionic stresses caused by elevating salinity above ambient levels. We expected that these changes would be accompanied by shifts in periphytic diatom assemblages that could be used to develop indicators of elevated salinity in fresh and brackish marshes of the southern Everglades. We also predicted that functional and compositional responses to simulated saltwater intrusion would be stronger in FW periphyton compared to BW mats, which are naturally exposed to fluctuating salinity because of their proximity to the coast.

\section{METHODS}

An in situ salinity addition experiment simulating pulsed saltwater intrusion was conducted in a freshwater (25 26' 6.11" N, 80 46'50.78” W) and brackish (25 13'13.38" N, 80 50'36.66' W) marsh in Everglades National Park, Florida, USA (Fig 1). The freshwater site (FW) was located $32 \mathrm{~km}$ from the coast and was characterized by long hydroperiod (inundated year-round), the presence of floating, epiphytic, and benthic calcareous periphyton mats, and dominated by Eleocharis cellulosa and Cladium jamaiscense macrophytes. Periphyton was absent in areas of high macrophyte density or during periods of extreme high-water levels. The brackish site (BW) was located approximately $4.5 \mathrm{~km}$ from the coast and experienced seasonal dry-downs ( $\sim 4$ months per year) during which the benthos was exposed to the atmosphere. This site was characterized by non-calcareous benthic periphyton (i.e., biofilms and filamentous mats) and was 
dominated by $C$. jamaicense with some interspersed dwarf Rhizophora mangle and Conocarpus erectus. Periphyton was often absent or too desiccated to sample dry-down months at the BW marsh.

Boardwalks were constructed at both locations to avoid any disturbance caused by stepping on the soils during the installation and sampling of treatment chambers. At both locations, we inserted twelve clear, circular (1.4-m diameter, 0.6-m height) polycarbonate chambers $30-\mathrm{cm}$ into the soil around the boardwalks to enclose plots of marsh for the experimental treatments. The chambers had a series of $10-\mathrm{cm}$ diameter holes around their perimeter and were equipped with a movable collar that allowed the chambers to be closed during treatment applications, to ensure the dosing water remained within the chamber, and opened the following day to allow natural exchange with the surrounding environment and minimize enclosure artifacts. Six of the twelve chambers were assigned the elevated salinity treatment while the remaining 6 were designated as controls; a buffer area was established between the control and salinity treatment chambers to avoid contamination of control plots. The experiment lasted 15 months from October 2014 to December 2015. During this time, salinity treatment (+SAL) chambers were dosed once a month with a known volume of brine prepared using source water and Instant Ocean $\subset$ sea salt mix to attain surface and porewater salinities approximately double the ambient conditions at each marsh (Stachelek et al. in review). The control (+AMB) chambers were dosed at the same time using site water alone to account for the effects elevating water levels in the treatment chambers when dosing. The dosing solution was applied by pumping dosing water from tubs (one with source water for the $+\mathrm{AMB}$ chambers and one with the saltwater mixture of the $+\mathrm{SAL}$ chambers) through a hose equipped with a gentle rain-style extension spray 
wand. The day after dosing, surface and porewater salinity was measured in each chamber (YSI Model 600 XL, Yellow Springs, OH) and water samples were collected for chemical analysis (see Wilson et al. in review for full water chemistries). Porewater salinity was measured from water samples extracted from three sampling wells (i.e., porewater sippers) placed randomly inside each chamber to a depth of $15-\mathrm{cm}$. Two porewater sippers were installed $0.5-\mathrm{m}$ outside the edge of each chamber to monitor any potential leakage of saltwater.

Periphyton samples were collected monthly for metabolism, nutrient content, and diatom species composition measurements except when mats were not present (e.g., BW dry-down events or extreme high-water levels at the FW site). When periphyton was present, two 10-mL periphyton samples were collected from each chamber at random for in situ biological oxygen demand (BOD) measurements using a $7.1 \mathrm{~cm} 2$ diameter plastic syringe. One $10 \mathrm{~mL}$ sample was placed in a $300-\mathrm{mL}$ clear bottle to measure periphyton net ecosystem productivity (NEP) and the other was placed in a $300-\mathrm{mL}$ dark bottle to measure periphyton ecosystem respiration (ER) as the change in dissolved oxygen (DO) over time using a YSI ProODO Dissolved Oxygen Meter. The paired clear and dark BOD bottles for each chamber were filled with site water and initial oxygen concentrations were measured before capping the bottles and submerging them in the marsh water where they incubated for $\sim 2 \mathrm{~h}$ under ambient conditions. After the incubation period, final oxygen concentrations were measured and the periphyton from the light bottles was transported back to the lab for further analyses. NEP and ER were standardized to the ash-free dry mass (AFDM) of the incubated sample. Oxygen production and consumption rates were converted to carbon production and consumption (mg C g AFDM-1 hr-1) by multiplying NEP and ER by the 
mass ratio of $\mathrm{C}: \mathrm{O} 2(0.357)$ and then dividing NEP by a photosynthetic quotient of 1.2. and ER by a respiratory quotient of 1 (Knapp et al. 2007). Gross primary production (GPP) was then calculated by adding the absolute value of the ER value to NEP. During months when periphyton biomass was too low for BOD incubations, we collected any periphyton material present in the mesocosm chambers for nutrient analyses and examination of diatom species composition.

In the lab, samples were placed in a 500-mL beaker and homogenized with deionized water (DI) water to create a periphyton slurry with a minimum volume of 200$\mathrm{mL}$ that could be subsampled for various analyses. The beaker was placed on a stir plate to facilitate continuous mixing of the slurry which was subsampled for AFDM, total carbon (TC), total nitrogen (TN), total phosphorus (TP), and diatom species composition. The AFDM subsample was placed in a drying oven at $80^{\circ} \mathrm{C}$ for $\geq 48 \mathrm{~h}$ to obtain a dry mass (g) measurement and then in a furnace where it was combusted at $500^{\circ} \mathrm{C}$ for $1 \mathrm{~h}$ to obtain the ash (mineral) mass (g). We calculated AFDM by the loss-on-ignition method as the difference between the ash mass and the total dry mass. The organic content of the periphyton biomass was calculated as the \% AFDM of the total dry mass and was used to later determine the organic and inorganic fractions of the TC. The TP subsample was dried at $80^{\circ} \mathrm{C}$ and ground down to a fine powder with a mortar and pestle. Colorimetric analysis was used to estimate TP concentrations in the periphyton subsamples, expressed as $\mu \mathrm{g} g$ AFDM-1, following the methods of Solorzano and Sharp (1980). TC and TN subsamples were ground by mortar and pestle, dried at $60^{\circ} \mathrm{C}$, and analyzed for total $\mathrm{C}$ and $\mathrm{N}$ content using a Flash 1112 elemental analyzer (CE Elantech, Lakewood, NJ) following standard procedures. The organic and inorganic fractions of TC were determined by calculating the 
$\%$ AFDM of the TC to get the organic fraction and then subtracting the organic fraction from the TC value to calculate the inorganic fraction.

The subsamples for diatom taxonomic analysis were cleaned of mineral debris and organic matter using the sulfuric acid oxidation methods described in Hasle and Fryxell (1970). We pipetted a known volume of cleaned diatom sample onto a glass coverslip, permanently mounted it on a microscope slide with Naphrax mounting medium (PhycoTech Inc., St. Joseph, Michigan), and viewed the diatoms under a compound light microscope (Zeiss Axioskop 2) equipped with differential interference contrast and a Leica DFC425 digital camera. We counted at least 500 valves along random transects at $600 \diamond$ magnification under oil immersion and identified them to the species level. Raw diatom counts were converted to relative abundance by standardizing the number of valves counted for each species by the total number of valves counted.

Differences in surface- and porewater salinity between $+\mathrm{AMB}$ and $+\mathrm{SAL}$ treatments and the effects of simulated pulses of saltwater intrusion on periphyton functional attributes were evaluated using analysis of variance (ANOVA) to test for treatment effects at the FW and BW sites separately. One-factor MANOVAs were used to evaluate treatment effects on periphyton metabolism (dependent variables: NEP, GPP, and ER) for each sampling date and across all sampling dates to test for mean effects over the entire study period. The same was done with TC, TN, TP, and chl-a as the dependent variables to test for saltwater exposure effects on periphyton nutrient content and algal biomass on each individual date and over the entire study period. Nutrient ratios (C:N, C:P, and $\mathrm{N}: \mathrm{P}$ ) were also analyzed in this manner. These analyses were conducted in SPSS (IBM SPSS Statistics V23.0). 
The effect of elevated salinity on periphytic diatom assemblages was examined on months when data were available for both the FW and BW sites (Oct 2014, Nov 2014, Jun 2015, and Oct 2015). Species present in $<3$ samples were removed from the dataset and relative abundances were arcsine-square root transformed. We used the PERMANOVA+ add-on package in PRIMER (v6, PRIMER-E Ltd, Clarke and Gorley 2006) to analyze the multivariate response of diatom species composition to elevated salinity using a 3-factor design (2 treatment levels (+AMB, $+\mathrm{SAL}) ; 2$ site levels (FW, BW); and 4 month levels). Pairwise tests were conducted on the treatment*site*month interaction term to identify significant treatment effects during each of the four sampling months at each site. Nonmetric multidimensional scaling (NMDS) was used to illustrate Bray-Curtis compositional dissimilarity in ordination space. Using R (R Core Team 2017 version 3.3.3), we ran a one-way analysis of similarity (anosim \{vegan $\}$ ) on FW and BW species datasets separately to determine if significant compositional dissimilarity between $+\mathrm{AMB}$ and + SAL plots existed when the four sampling dates were considered together. Species driving compositional dissimilarity between $+\mathrm{AMB}$ and $+\mathrm{SAL}$ treatment chambers at the FW and BW site were determined using the multi-level pattern analysis available in the indicspecies package (multipatt \{indicspecies\}) in R (De Cáceres and Legendre 2009).

\section{RESULTS}

Addition of the Instant Ocean $\odot$ brine elevated surface and porewater salinity in the treatment plots at both the FW and BW sites (Fig 2). Mean surface water salinity at the FW site was significantly higher $(\mathrm{p}<0.05)$ in $+\mathrm{SAL}$ treatment plots $(1.3 \pm 1.1 \mathrm{ppt})$ compared 
to ambient (+AMB plots) salinity $(0.2 \pm 0.1 \mathrm{ppt})$ when averaged over all sampling dates, as well as on all individual sampling dates. At the BW site, mean surface water salinity in the + SAL treatment plots $(6.6 \pm 3.6 \mathrm{ppt})$ was significantly $(\mathrm{p}=0.000)$ elevated above ambient conditions $(4.6 \pm 1.9 \mathrm{ppt})$ when averaged over the duration of the experiment. However, salinity in + SAL plots was not significantly higher than +AMB plots on the last four sampling dates (Sept - Dec 2015). Mean porewater salinity in the + SAL treatment plots was elevated 3 ppt above ambient at the FW site and 5 ppt above ambient at the BW site. Average ambient porewater salinity at the FW site was $0.28 \mathrm{ppt}( \pm 0.08)$ and was elevated to $2.9 \mathrm{ppt}( \pm 1.2)$ in the + SAL plots; salinity was significantly higher in the $+\mathrm{SAL}$ plots compared to + AMB plots on all sampling dates $(p<0.05)$. Similarly, salinity in + SAL plots at the BW site was significantly greater than salinity in +AMB plots on all sampling dates $(\mathrm{p}<0.05)$ with mean ambient porewater salinities of $10.3 \mathrm{ppt}( \pm 2.2)$ and mean treatment salinities of $15.3 \mathrm{ppt}( \pm 2.6)$.

Exposure of $\mathrm{FW}$ periphyton mats to a $\sim 1$ ppt elevation in surface water salinity and 3 ppt elevation in porewater salinity caused sufficient osmotic stress to induce physiological responses such as reduced productivity, $\mathrm{C}$ content, and nutrient concentrations. Periphyton NEP, GPP, TC, TN, and TP were all significantly lower $(\mathrm{p}<$ $0.05)$ in the + SAL plots compared to $+\mathrm{AMB}$ plots, but there was no effect on periphyton ER or chl-a concentrations (Table 1). Despite the significant overall treatment effects, we found temporal variability in periphyton functional responses to elevated salinity, particularly on the summer sampling dates (Fig 3A). We found no treatment effects on periphyton TC or TP in June and August 2015 and no effect on TN in June 2015. 
Periphyton productivity was not measured in June, but no treatment effects on NEP or GPP were detected in the Aug or Sept 2015 samples.

$\mathrm{BW}$ periphyton mats were more resilient to the saltwater treatment compared to the FW periphyton. We found no significant treatment effect on periphyton NEP, GPP, ER, TC, TN, TP, or chl-a when averaged over all sampling dates (Table 1). However, temporal variability in treatment effects were detected (Fig 3B). Periphyton NEP and GPP were suppressed with the salinity treatment immediately after the first saltwater dose but did not respond to the treatment in any of the later sampling dates where metabolism was measured. Periphyton collected after the first saltwater dosing had greater $\mathrm{C}$ content but no effect thereafter. TN and TP were unaffected with the first dosing and remained unaffected throughout the experiment, except for the Nov 2014 sample when TN was reduced and the Jun 2015 sample when both TN and TP were reduced in the treatment plots.

Periphyton mats from both the FW and BW marsh sites were net autotrophic during all sampling events regardless of treatment. At the FW site, mean NEP values ranged from 4.8 to $12.8 \mathrm{mg} \mathrm{C}$ g AFDM-1 hr-1 in the +AMB plots and from 1.4 to $7.0 \mathrm{mg}$ C g AFDM$1 \mathrm{hr}-1$ in the +SAL plots. Mean NEP values at the BW sites ranged from 4.0 to $10.1 \mathrm{mg} \mathrm{C}$ g AFDM-1 hr-1 in +AMB plots and from 0.3 to $12.0 \mathrm{mg} \mathrm{C} \mathrm{g} \mathrm{AFDM-1} \mathrm{hr-1} \mathrm{in} \mathrm{+SAL} \mathrm{plots.}$ Periphyton ER rates were generally low at both the FW (-0.9 and $-4.3 \mathrm{mg} \mathrm{C}$ g AFDM-1 hr1) and BW (-0.5 and $-4.0 \mathrm{mg} \mathrm{C}$ g AFDM-1 hr-1) sites regardless of the treatment group. Despite the reduction in periphyton TC, TN, and TP, particularly at FW site, mat $\mathrm{C}: \mathrm{P}$ and $\mathrm{N}: \mathrm{P}$ ratios were not significantly affected by the elevated salinity treatment at either the fresh $(\mathrm{F}=1.90, \mathrm{p}=0.173 ; \mathrm{F}=0.05, \mathrm{p}=0.823)$ or brackish $(\mathrm{F}=0.379, \mathrm{p}=0.541 ; \mathrm{F}=0.953$, $\mathrm{p}=0.333$ ) marsh when averaged over all sampling dates. However, periphyton $\mathrm{C}: \mathrm{N}$ was 
significantly higher in the $+\mathrm{SAL}$ compared to $+\mathrm{AMB}$ plots at both the fresh $(\mathrm{F}=7.893$, $\mathrm{p}=0.007)$ and brackish $(\mathrm{F}=6.624, \mathrm{p}=0.012)$ sites.

The PERMANOVA analysis detected significant dissimilarity in diatom species composition in response to all three main effects (treatment, site, and month) and for all interaction terms (Table 2). Based on these results, we conducted post-hoc pairwise contrasts on the 3-way interaction term (treatment*site*month) to search for seasonal patterns in treatment (+AMB and $+\mathrm{SAL}$ ) effects at the FW and BW sites separately. We found significant compositional dissimilarity between treatment and control plots at the FW site on all four sampling months and the ordination illustrated that the separation between + AMB and + SAL groups increased over time (Table 3, Fig 4). Compositional dissimilarity between treatments at the BW site was significant only after the first monthly dosing event (Oct 2014) and in June 2015 (Table 3, Fig 4). The ordinations confirm that divergence between treatment groups was greatest after the first saltwater dosing and that the significance of the dissimilarity between treatments in the June samples may have been driven by an outlier in the + SAL group.

We also observed seasonal shifts in species composition within each treatment group at both sites (Fig 4A). At the FW site, diatom assemblages within the +AMB group remained relatively similar during the first 3 sampling dates but deviated considerably on the last date (Oct 2015). Within the +SAL group, the first two sampling dates clustered closer together, while the June 2015 and Oct 2015 samples each formed separate clusters. We observed similar within-treatment group variance trends at the BW site. The +AMB samples from Oct and Nov 2014 grouped closely together, while the June and Oct 2015 
samples formed two separate clusters. This same within-treatment seasonal pattern was observed for the +SAL group.

Species dissimilarity between $+\mathrm{AMB}$ and $+\mathrm{SAL}$ treatments was examined across the four sampling dates to look for overall treatment effects at each site without considering seasonal variability and found that treatment groups had significantly different diatom assemblages at both the FW (ANOSIM R=0.530, $\mathrm{p}=0.001)$ and the $\mathrm{BW}($ ANOSIM $\mathrm{R}=$ 0.748, $\mathrm{p}=0.001$ ) site (Fig 4B). This was evident from the boxplots of ranked species dissimilarity which showed that between treatment group dissimilarity was greater than within group dissimilarity. In general, periphytic diatoms in FW and BW marshes formed two distinct assemblages and exhibited similar statistical dispersion in the dissimilarity metric (ANOSIM $\mathrm{R}=1, \mathrm{p}=0.001$ ) (Fig 4B). Interestingly, dispersion within the $+\mathrm{SAL}$ treatment group was much greater than within $+\mathrm{AMB}$ group for both the $\mathrm{FW}$ and $\mathrm{BW}$ marsh indicating that saltwater exposure causes higher variance in diatom assemblages (Fig 4B). Diatom indicators selected by the multi-level pattern analysis (multipatt \{indecspecies $\}$ ) for $+\mathrm{AMB}$ and $+\mathrm{SAL}$ treatment groups at the FW and BW sites are listed Table 4 (see Fig 5).

\section{DISCUSSION}

Periphyton is considered a primary ecosystem engineer in karstic, freshwater wetlands. However, because these landscapes are typically located along coastlines, saltwater intrusion has the potential to alter the performance, and thus the ecological roles, of these dominant primary producers. In this study, we demonstrated that simulated 
monthly pulses of saltwater intrusion into naturally freshwater marshes suppressed periphyton primary productivity and reduced the $\mathrm{TC}, \mathrm{TN}$, and $\mathrm{TP}$ content of the mats. These functional responses to pulsed salinity increases of only 1 ppt above ambient surface water levels were accompanied by significant shifts in periphytic diatom assemblages, underscoring the effectiveness of diatoms as fast and sensitive indicators of environmental variability. Brackish water periphyton was fundamentally different in physical structure and species composition than the cohesive, calcareous mats found in freshwater marshes and was more resilient to the monthly pulses of elevated salinity. With a 2 ppt increase in surface water salinity, these mats exhibited suppressed productivity immediately after the first salinity dosing, but were unaffected thereafter. Likewise, the salinity pulses did not significantly affect the overall $\mathrm{TC}, \mathrm{TN}$, or $\mathrm{TP}$ content of the mats at the brackish site. Despite the metabolic and nutritional resilience of brackish water periphyton mats to the experimentally elevated salinity, the periphytic-diatom assemblages responded to the saltwater pulses with altered species composition.

The movement of marine water into the freshwater marshes of the coastal Everglades subjects stenohaline organisms to stressors that can have detrimental effects on their physiological functions (Kozlowski 1997). We show that freshwater periphyton communities respond to relatively low-level salinity increases with depressed NEP while periphyton from the brackish marsh were more resilient to elevated salinity, despite an initial reduction in NEP. This was not surprising given that periphyton in brackish marshes are naturally subjected to fluctuating salinity given their proximity to the coast. However, we were only able to achieve salinities of 2 ppt above ambient in the surface water and 5 ppt above ambient in the porewater; exposure to higher salinities are expected to illicit 
stronger functional responses in BW periphyton. Periphyton ER rates were unaffected by the salinity treatment in both the FW and BW marsh sites suggesting that the decline in photosynthetic carbon sequestration (NEP) was largely driven by lowered periphyton GPP. One explanation for the reduction in GPP is the osmotic stress and resulting intracellular water deficits caused by elevated salinity (Hasegawa et al. 2000) Water is essential to photosynthesis because it acts as the electron donor in photosystem II replacing the reaction center electron that is mobilized from the chlorophyll molecule into the electron transport chain when excited by light energy (Falkowski and Raven 2007). Therefore, plasmolysis, and many other cellular disturbances caused by exposure to saltwater, can limit photosynthetic carbon fixation and eventually result in cell death. Affenzeller et al. (2009) experimentally tested the effect of elevated salinity on cultured samples of a freshwater green alga and found significant declines in GPP which they attributed to changes in photosynthetic enzyme activity and disruption of transport across the chloroplast envelop membrane. Although several studies have tested the effect of salinity on intertidal or marine algae (Macler 1988, Satoh et al. 1983), our study is one of the few to experimentally test the effects of elevated salinity on freshwater algae (Affenzeller et al. 2009), and particularly freshwater periphyton mats. Rejmankova and Komarkova (2005) conducted a factorial mesocosm experiment to assess the response of periphyton from karstic wetlands in Belize to combinations of low, medium, and high salinity, $\mathrm{P}$, and $\mathrm{N}$ but found that, despite trends of lower primary productivity at elevated salinity, the overall effect of salinity was not significant. Similarly, Ewe et al. (2006) examined periphyton GPP along a natural salinity gradient in the Florida Everglades and found that, although productivity values were higher in the freshwater marshes of Taylor Slough compared to downstream 
in Florida Bay, these results were highly variable. These variable results suggest that the mechanisms driving periphyton responses to saltwater exposure may be less clear than for a single organism because these mats are essentially micro-ecosystems inhabited by a suite of auto- and heterotroph organisms.

The salinity-induced decline in freshwater periphyton GPP and NEP was reflected by the lower TC content of salt-treated mats. We hypothesize that reduced photosynthetic carbon fixation leaves less organic carbon available for biomass production and that the potential loss of calcium carbonate precipitating cyanobacteria in response to greater salinity reduces the amount of inorganic carbon stored in the mats. Periphyton TN and TP concentrations were also reduced in salt-treated mats suggesting nutrient uptake suppression caused by ionic stress. The accumulation of $\mathrm{Na}+$ and $\mathrm{Cl}$ - ions may create ionic competition that inhibits assimilation of essential nutrients, such as $\mathrm{NH}+4$, NO-3, PO-4, K+, and Ca2+ (Alam 1999, Sudhir and Murthy 2004, Hu and Schmidhalter 2005). The reduction in $\mathrm{N}$ and $\mathrm{P}$ uptake is another possible explanation for the decline in NEP and GPP, given the essential roles these nutrients play in synthesizing chlorophyll a $(\mathrm{N})$ and ATP and NADPH (P). Studies looking at the effects of salinity on plant nutrient uptake support our findings that salt stress reduces uptake of essential nutrients (Kozlowski 1997, Grattan and Grieve 1999). For example, Brown et al. 2006 reported reduced N and P uptake by Spartina alterniflora exposed to experimentally elevated salinity levels and Seob et al. (2010) showed that nitrate and phosphate uptake was reduced in the estuarine macroalgal Ulva pertusa when salinity was above or below its 15-20 psu optimum. Lower TP concentrations in periphyton mats with added saltwater may also be caused by abiotic mechanisms. Saltwater has been shown to cause $\mathrm{P}$ desorption from $\mathrm{CaCO} 3$ bedrock 
through anion competition in the Everglades (Price et al. 2006, Flower et al. 2016), and a similar mechanism may be at play within the calcareous periphyton mats that causes $\mathrm{CaCO} 3$-bound $\mathrm{P}$ to be released into the surrounding water.

Changes in freshwater periphyton functionality were accompanied by significant shifts in diatom composition. Compositional shifts were evident after one pulse of seawater dosing and continued to diverge further from the ambient community with monthly pulsed additions over the year study period. The growing separation between $+\mathrm{AMB}$ and $+\mathrm{SAL}$ treatment groups over time suggests that divergence in diatom assemblages in response to monthly pulses of saltwater exposure may be additive. However, because samples were only collected the day after dosing, we cannot be certain that the diatom assemblage (and periphyton functions) did not recover before the following monthly dosing and therefore we cannot draw conclusions on the resiliency of FW periphyton and diatom assemblages to pulsed saltwater intrusion. Exposure to monthly pulses of saltwater, as opposed to continuously elevated salinity, may allow freshwater communities to recover or impede the establishment of a mostly salt-adapted assemblage before the following dosing. This may explain why we did not see functional redundancy in freshwater periphyton which would be expected if a salt-adapted community had become established. Functional redundancy was evident at the BW site, where periphyton functionality was largely unaffected by the monthly pulses of elevated salinity while the diatom assemblage exhibited significant shifts in response to the saltwater treatments. Although the periphyticdiatom assemblage at the brackish marsh responded to a 2 ppt salinity elevation with altered species composition, albeit less so than FW periphytic-diatoms, other BW periphyton communities (e.g., cyanobacteria and green algae) may be less sensitive to 
small, discontinuous salinity increases explaining why we did not observe significant functional responses in BW periphyton. These findings highlight the sensitivity of diatoms to small scale changes in salinity compared to other periphytic communities and supports the idea that diatoms are stronger indicators of small, short-term changes in salinity compared to periphyton functional metrics.

Saltwater intrusion not only elicits negative physiological responses in freshwater communities, but also stimulates changes in community structure as coastal transgression modifies environmental conditions to favor salt-tolerant communities (Ross et al. 2000, Davis et al. 2005, Troxler et al. 2014). This study represents a first step in understanding how freshwater, mat-forming algal communities respond to elevated salinity, an important area of research given the threat of saltwater intrusion on coastal, freshwater wetlands and the importance of algal communities in these systems. In general, much of the literature on the effects of elevated salinity on primary productivity in freshwater coastal wetlands, whether experimental or gradient-based, is focused either on macrophyte or whole ecosystem productivity (Webb and Mendelssohn 1996, Childers et al. 2006b, Neubauer 2013, Troxler et al. 2014, Wilson et al. in review). While this information is imperative to our understanding of saltwater intrusion impacts on the ecosystem, we need to assess impacts to other key ecosystem components, such as periphyton, to achieve a comprehensive understanding of the potential consequences of saltwater intrusion. Although salinity is a dominant driver of plant and algal community composition and metabolic functioning, saltwater intrusion into coastal freshwater marshes will not only elevate salinity but alter the elemental composition of site water as well. Among other water chemistry changes, saltwater intrusion is expected to provide a phosphorus subsidy 
to the naturally P-limited marshes of the coastal Everglades (Childers et al. 2006, Price et al. 2006). Therefore, it is important to understand how periphyton, and other key ecosystem components, respond to the individual and synergistic effects of increased salinity and nutrient (e.g., P) availability. Studies addressing these interactive effects will allow us to expand the use of periphyton and their diatom assemblages as tools for environmental assessments related to sea level rise and saltwater intrusion in the Everglades and other karstic, freshwater wetlands.

\section{ACKNOWLEDGMENTS}

We thank Shawn Abrahams, Michelle Blaha, Marbelys Garriga, Adam Hines, Rowan Johnson, Oliver Ljustina, Melinda Martinez, Fabiola Santamaria, Chris Sillivan, Frank Skiff, Emily Standen, Ryan Stolee, and Mary Grace Thibault for help in the field; Andres Leon and Sara Osorio for help in sample processing and data entry; and Franco Tobias for laboratory assistance particularly with species identification. Funding for research was supported by Florida Sea Grant R/C-S-56, including cooperative agreements with the South Florida Water Management District, the Everglades Foundation, and Everglades National Park. Additional funding was provided through the National Science Foundation's Florida Coastal Everglades Long Term Ecological Research Program (DEB1237517). This is contribution number XXX from the Southeast Environmental Research Center in the Institute of Water and Environment at Florida International University. 


\section{LITERATURE CITED}

Affenzeller, M.J., A. Darehshouri, A. Andosch, C. Lütz, and U. Lütz-Meindl. 2009. Salt stress-induced cell death in the unicellular green alga Micrasterias denticulata. Journal of Experimental Botany 60: 939-954.

Alam, S.M., 1999. Nutrient uptake by plants under stress conditions. In Handbook of Plant and Crop Stress 2, 285-313, ed. M. Pessarakli. Marcel Dekker, Inc. New York, NY.

Azim, M.E. and T. Asaeda. 2005. Periphyton structure, diversity and colonization. In Periphyton: Ecology, Exploitation and Management 15-35, eds. M.E. Azim, M.C. Verdegem, A.A. van Dam, and M.C. Beveridge. CABI Publishing, Cambridge, MA.

Briceño, H., G. Miller, S.E. Davis. 2014. Relating freshwater flow with estuarine water quality in the Southern Everglades mangrove ecotone. Wetlands 34:101-111.

Brown, C.E., S.R. Pezeshki, and R.D. DeLaune. 2006. The effects of salinity and soil drying on nutrient uptake and growth of Spartina alterniflora in a simulated tidal system. Environmental and Experimental Botany 58:140-148.

Childers, D.L., J.N. Boyer, S.E. Davis, C.J. Madden, D.T. Rudnick, F.H. Sklar. $2006 b$. Relating precipitation and water management to nutrient concentrations in the oligotrophic "upside-down" estuaries of the Florida Everglades. Limnology and Oceanography 51: 602-616.

Childers, D.L., D. Iwaniec, D. Rondeau, G. Rubio, E. Verdon, and C.J. Madden. 2006a. Responses of sawgrass and spikerush to variation in hydrologic drivers and salinity in Southern Everglades marshes. Hydrobiologia 569: 273-292.

Choi, T.S., E.J. Kang, J.H. Kim, and K.Y. Kim. 2010. Effect of salinity on growth and nutrient uptake of Ulva pertusa (Chlorophyta) from an eelgrass bed. Algae 25: 1726.

Clarke K.R. and R.N. Gorley. 2006. Primer v6: User Manual/Tutorial. Plymouth: PRIMER-E.

Davis, S. M., D.L. Childers, J.J. Lorenz, H.R. Wanless, and T.E. Hopkins. 2005. A conceptual model of ecological interactions in the mangrove estuaries of the Florida Everglades. Wetlands 25:832-842.

De Cáceres, M. and P. Legendre. 2009. Associations between species and groups of sites: indices and statistical inference. Ecology 90: 3566-3574. 
Desrosiers, C., J. Leflaive, A. Eulin, and L. Ten-Hage. 2013. Bioindicators in marine waters: benthic diatoms as a tool to assess water quality from eutrophic to oligotrophic coastal ecosystems. Ecological Indicators 32: 25-34.

Dessu, SB, R.M. Price, T.G. Troxler, and J.S. Kominoski. 2018 Effects of sea-level rise and freshwater management on long-term water levels and water quality in the Florida Coastal Everglades. Journal of Environmental Management 211: 164-176.

Ewe, S.M., E.E. Gaiser, D.L. Childers, D. Iwaniec, V.H. Rivera-Monroy, and R.R. Twilley. 2006. Spatial and temporal patterns of aboveground net primary productivity (ANPP) along two freshwater-estuarine transects in the Florida Coastal Everglades. Hydrobiologia 569: 459-474.

Falkowski, P.G. and J.A. Raven. 2013. Aquatic photosynthesis. Princeton University Press.

Flower, H., M. Rains, D. Lewis, J.Z. Zhang, and R. Price. 2017. Saltwater intrusion as potential driver of phosphorus release from limestone bedrock in a coastal aquifer. Estuarine, Coastal and Shelf Science 184: 166-176.

Gaiser, E. 2009. Periphyton as an indicator of restoration in the Florida Everglades. Ecological Indicators 9: 37-45.

Gaiser, E. E., P.V. McCormick, S.E. Hagerthey, and A.D. Gottlieb. 2011. Landscape patterns of periphyton in the Florida Everglades. Critical Reviews in Environmental Science and Technology 41: 92-120.

Gaiser, E. E., J.C. Trexler, R.D. Jones, D.L. Childers, J.H. Richards, and L.J. Scinto. 2006. Periphyton responses to eutrophication in the Florida Everglades: crosssystem patterns of structural and compositional change. Limnology and Oceanography 51: 617:630.

Gaiser, E., J.M.L. Hée, F.A. Tobias, and A.H. Wachnicka. 2010. Mastogloia smithii var lacustris Grun.: a structural engineer of calcareous mats in karstic subtropical wetlands. Proceedings of the Academy of Natural Sciences of Philadelphia 160: $99-112$.

Gaiser, E., A. Wachnicka, P. Ruiz, F. Tobias, and M. Ross. 2005. Diatom indicators of ecosystem change in subtropical coastal wetlands. Estuarine Indicators. CRC Press, Boca Raton, FL.

Grattan, S.R. and C.M. Grieve. 1998. Salinity-mineral nutrient relations in horticultural crops. Scientia Horticulturae 78: 127-157.

Hagerthey, S. E., B.J. Bellinger, K. Wheeler, M. Gantar, E. Gaiser. 2011. Everglades periphyton: a biogeochemical perspective. Critical Reviews in Environmental Science and Technology 41: 309-343. 
Hasegawa, P.M., R.A. Bressan, J.K. Zhu, and H.J. Bohnert. 2000. Plant cellular and molecular responses to high salinity. Annual Review of Plant Biology 51: 463499.

Herbert, E.R., P. Boon, A.J. Burgin, S.C. Neubauer, R.B. Franklin, M. Ardón, K.N. Hopfensperger, L.P. Lamers, and P. Gell. 2015. A global perspective on wetland salinization: ecological consequences of a growing threat to freshwater wetlands. Ecosphere 6:1-43.

$\mathrm{Hu}, \mathrm{Y}$. and U. Schmidhalter. 2005. Drought and salinity: a comparison of their effects on mineral nutrition of plants. Journal of Plant Nutrition and Soil Science 168: 541549.

Ikenaga, M., R. Guevara, A.L. Dean, C. Pisani, and J.N. Boyer. 2010. Changes in community structure of sediment bacteria along the Florida coastal everglades marsh-mangrove-seagrass salinity gradient. Microbial Ecology 59: 284-295.

Iwaniec, D.M., D.L. Childers, D. Rondeau, C.J. Madden, and C. Saunders. 2006. Effects of hydrologic and water quality drivers on periphyton dynamics in the southern Everglades. Hydrobiologia 569: 223-235.

Johnson, R.E., N.C. Tuchman, and C.G. Peterson. 1997. Changes in the vertical microdistribution of diatoms within a developing periphyton mat. Journal of the North American Benthological Society 16: 503-519.

Knapp, A.K., J.M. Briggs, and D.L. Childers. 2007. Estimating aboveground net primary production in grassland and herbaceous dominated systems. In Principles and Standards for Measuring Net Primary Production in Long-term Ecological Studies 27-48, eds T.J. Fahey and A.K. Knap. Oxford University Press.

Kozlowski, T.T. 1997. Responses of woody plants to flooding and salinity. Tree Physiology 17: 490.

Krauss, K.W., A.S. From, T.W. Doyle, T.J. Doyle, and M.J. Barry. 2011. Sea-level rise and landscape change influence mangrove encroachment onto marsh in the Ten Thousand Islands region of Florida, USA. Journal of Coastal Conservation 15: 629-638.

La Hée, J. M. and E. E. Gaiser. 2012. Benthic diatom assemblages as indicators of water quality in the Everglades and three tropical karstic wetlands. Freshwater Science 31: 205-221.

Lee, S. S., E.E. Gaiser, and J.C. Trexler. 2013. Diatom-based models for inferring hydrology and periphyton abundance in a subtropical karstic wetland: Implications for ecosystem-scale bioassessment. Wetlands 33: 157-173. 
Lu, C. and A. Vonshak. 2002. Effects of salinity stress on photosystem II function in cyanobacterial Spirulina platensis cells. Physiologia Plantarum 114: 405-413.

Macler, B.A. 1988. Salinity effects on photosynthesis, carbon allocation, and nitrogen assimilation in the red alga, Gelidium coulteri. Plant Physiology 88: 690-694.

Mazzei, V. and E. Gaiser. 2018. Diatoms as tools for inferring ecotone boundaries in a coastal freshwater wetland threatened by saltwater intrusion. Ecological Indicators 88: 190-204.

McCormick, P. V. and M.B. O'Dell. 1996. Quantifying periphyton responses to phosphorus in the Florida Everglades: a synoptic-experimental approach. Journal of the North American Benthological Society 15: 450-468.

McCormick, P.V. and R.J. Stevenson. 1998. Periphyton as a tool for ecological assessment and management in the Florida Everglades. Journal of Phycology 34: $726-733$.

Mendelssohn, I.A., D.P. Batzer, C.R. Holt, and S.A. Graham. 2006. Abiotic constraints for wetland plants and animals. In Ecology of Freshwater and Estuarine Wetlands 82-114, eds. D. Batzer and R.R. Sharitz. University of California Press.

Neubauer, S.C. 2013. Ecosystem responses of a tidal freshwater marsh experiencing saltwater intrusion and altered hydrology. Estuaries and Coasts 36: 491-507.

Nodine, E.R. and E.E. Gaiser. 2014. Distribution of diatoms along environmental gradients in the Charlotte Harbor, Florida (USA), estuary and its watershed: implications for bioassessment of salinity and nutrient concentrations. Estuaries and Coasts 37: 864-879.

Pan, Y., R.J. Stevenson, P. Vaithiyanathan, J. Slate, and C.J. Richardson. 2000. Changes in algal assemblages along observed and experimental phosphorus gradients in a subtropical wetland, USA. Freshwater Biology 44: 339-353.

Potapova, M. and D.F. Charles. 2007. Diatom metrics for monitoring eutrophication in rivers of the United States. Ecological Indicators 7: 48-70.

Price, R. M., P.K. Swart, and J.W. Fourqurean. 2006. Coastal groundwater discharge-an additional source of phosphorus for the oligotrophic wetlands of the Everglades. Hydrobiologia 569: 23-36.

Rejmánková, E. and J. Komárková. 2000. A function of cyanobacterial mats in phosphorus-limited tropical wetlands. Hydrobiologia 431: 135-153.

Rejmánková, E. and J. Komárková. 2005. Response of cyanobacterial mats to nutrient and salinity changes. Aquatic Botany 83: 87-107. 
Ross, M.S., J.F. Meeder, J.P. Sah, P.L. Ruiz, and G.J. Telesnicki. 2000. The Southeast Saline Everglades revisited: a half-century of coastal vegetation change. Journal of Vegetation Science 11: 101-112

Saha, A.K., C.S. Moses, R.M. Price, V. Engel, T.J. Smith, and G. Anderson. 2012. A hydrological budget (2002-2008) for a large subtropical wetland ecosystem indicates marine groundwater discharge accompanies diminished freshwater flow. Estuaries and Coasts 35: 459-474.

Saha, A.K., S. Saha, J. Sadle, J. Jiang, M.S. Ross, R.M. Price, L.S. Sternberg, and K.S. Wendelberger. 2011. Sea level rise and South Florida coastal forests. Climatic Change 107: 81-108.

Schedlbauer, J.L., J.W. Munyon, S.F. Oberbauer, E.E. Gaiser, and G. Starr. 2012. Controls on ecosystem carbon dioxide exchange in short-and long-hydroperiod Florida Everglades freshwater marshes. Wetlands 32: 801-812.

Sola, A.D., L. Marazzi, M.M. Flores, J.S. Kominoski, and E.E. Gaiser. 2018. Short-Term Effects of Drying-Rewetting and Long-Term Effects of Nutrient Loading on Periphyton N: P Stoichiometry. Water 10:105.

Stevenson, J. 2014. Ecological assessments with algae: a review and synthesis. Journal of Phycology 50: 437-461.

Stevenson, R.J., Y. Pan, and H. van Dam. 1999. Assessing environmental conditions in rivers and streams with diatoms. In The Diatoms: Applications for the Environmental and Earth Sciences, 2, 57-85. Cambridge University Press, Cambridge.

Sudhir, P. and S.D.S. Murthy. 2004. Effects of salt stress on basic processes of photosynthesis. Photosynthetica 42: 481-486.

Touchette, B.W. 2007. Seagrass-salinity interactions: physiological mechanisms used by submersed marine angiosperms for a life at sea. Journal of Experimental Marine Biology and Ecology 350: 194-215.

Trexler, J.C., E.E. Gaiser, J.S. Kominoski, and J. Sanchez. 2015. The role of periphyton mats in consumer community structure and function in calcareous wetlands: lessons from the Everglades. Microbiology of the Everglades Ecosystem. Science Publications, CRC Press, Boca Raton, 155-179.

Troxler, T.G., D.L. Childers, and C.J. Madden. 2014. Drivers of decadal-scale change in southern Everglades wetland macrophyte communities of the coastal ecotone. Wetlands 34: 81-90.

Troxler, T.G., E. Gaiser, J. Barr, J.D. Fuentes, R. Jaffe, D.L. Childers, L. Collado-Vides, V.H. Rivera-Monroy, E. Castaneda-Moya, W. Anderson, and R. Chambers. 2013. 
Integrated carbon budget models for the Everglades terrestrial-coastal-oceanic gradient: current status and needs for inter-site comparisons. Oceanography 26: 98-107.

Vymazal, J. and C.J. Richardson. 1995. Species composition, biomass, and nutrient content of periphyton in the Florida Everglades. Journal of Phycology 31: 343354.

Wachnicka, A., E.E Gaiser, L. Collins, T. Frankovich, and J. Boyer. 2010. Distribution of diatoms and development of diatom-based models for inferring salinity and nutrient concentrations in Florida Bay and adjacent coastal wetlands of South Florida. Estuaries and Coasts 33: 1080-1098.

Webb, E.C. and Mendelssohn, I.A., 1996. Factors affecting vegetation dieback of an oligohaline marsh in coastal Louisiana: field manipulation of salinity and submergence. American Journal of Botany, pp.1429-1434.

White, E. and D. Kaplan. 2017. Restore or retreat? Saltwater intrusion and water management in coastal wetlands. Ecosystem Health and Sustainability 3:1 DOI: $10.1002 /$ ehs 2.1258

Wilson, B.J., S. Servais, V. Mazzei, S.E. Davis, S. Kelly, E. Gaiser, J.S. Kominoski, J. Richards, D. Rudnick, F. Sklar, J. Stachelek, and T.G. Troxler. In review. Biogeochemical and physiological effects of simulated sea level rise in the coastal Florida Everglades. Ecological Applications. 
Table 3-1. Means and standard deviations (STDEV) for periphyton net ecosystem productivity (NEP), gross primary productivity (GPP), respiration (R), total carbon (TC), total nitrogen (TN), and total phosphorus (TP) averaged across all sampling dates at the freshwater $(\mathrm{FW})$ and brackish $(\mathrm{BW})$ marsh. ANOVA $p$-values indicating the probability that each variable is significantly different between control $(+\mathrm{AMB})$ and treatment $(+\mathrm{SAL})$ plots $(*=p<0.05)$.

\begin{tabular}{|c|c|c|c|c|c|c|c|}
\hline \multirow[t]{2}{*}{ Site } & \multirow[t]{2}{*}{ Response } & \multicolumn{2}{|c|}{$+\mathrm{AMB}$} & \multicolumn{2}{|c|}{+ SAL } & \multicolumn{2}{|c|}{ ANOVA } \\
\hline & & Mean & STDEV & Mean & STDEV & $F$ statistic & $p$-value \\
\hline \multirow[t]{6}{*}{ FW } & NEP (mg C/g AFDM/hr) & 9.0 & 4.3 & 5.0 & 3.1 & 14.04 & $0.001 *$ \\
\hline & GPP (mg C/g AFDM/hr) & 11.7 & 5.1 & 6.9 & 4.2 & 2.49 & $0.001 *$ \\
\hline & $\mathrm{ER}(\mathrm{mg} \mathrm{C} / \mathrm{g}$ AFDM/hr) & -2.6 & 1.7 & -1.7 & 2.1 & 12.33 & 0.122 \\
\hline & $\mathrm{TC}(\mathrm{mg} / \mathrm{g})$ & 293.7 & 37.0 & 248.7 & 16.1 & 46.65 & $0.000 *$ \\
\hline & $\mathrm{TN}(\mathrm{mg} / \mathrm{g})$ & 14.8 & 4.7 & 10.7 & 2.3 & 22.05 & $0.000 *$ \\
\hline & $\mathrm{TP}(\mu \mathrm{g} / \mathrm{g})$ & 194.0 & 68.0 & 153.0 & 73.0 & 5.26 & $0.025 *$ \\
\hline \multirow[t]{6}{*}{$\mathrm{BW}$} & NEP (mg C/g AFDM/hr) & 5.1 & 4.6 & 5.4 & 5.6 & 0.05 & 0.826 \\
\hline & GPP (mg C/g AFDM/hr) & 6.7 & 5.5 & 7.5 & 6.5 & 1.61 & 0.211 \\
\hline & ER (mg C/g AFDM/hr) & -1.4 & 1.4 & -1.9 & 1.5 & 0.26 & 0.611 \\
\hline & $\mathrm{TC}(\mathrm{mg} / \mathrm{g})$ & 353.8 & 27.6 & 360.8 & 37.9 & 0.75 & 0.390 \\
\hline & $\mathrm{TN}(\mathrm{mg} / \mathrm{g})$ & 25.0 & 3.4 & 24.1 & 5.0 & 0.75 & 0.391 \\
\hline & $\mathrm{TP}(\mu \mathrm{g} / \mathrm{g})$ & 525.4 & 111.4 & 500.7 & 150.6 & 1.69 & 0.199 \\
\hline
\end{tabular}


Table 3-2. PERMANOVA output table showing significant main effects of treatment, site, and month, and a significant 3-way interaction effect, on diatom species dissimilarity.

\begin{tabular}{llllll}
\hline Source & df & \multicolumn{1}{c}{ SS } & \multicolumn{1}{c}{ MS } & Pseudo-F & P(perm) \\
\hline Treatment & 1 & 1344.9 & 1344.9 & 5.0866 & 0.001 \\
Site & 1 & 61280 & 61280 & 231.76 & 0.001 \\
Month & 3 & 6015.4 & 2005.1 & 7.5834 & 0.001 \\
Treatment*Site & 1 & 1611 & 1611 & 6.0929 & 0.001 \\
Treatment*Month & 3 & 1863.4 & 621.13 & 2.3491 & 0.001 \\
Site*Month & 3 & 12138 & 4045.9 & 15.302 & 0.001 \\
Treatment*Site*Month & 3 & 1847.6 & 615.88 & 2.3293 & 0.001 \\
Res & 32 & 8461.1 & 264.41 & & \\
Total & 47 & 94561 & & & \\
\hline
\end{tabular}

Table 3-3. Significance of post-hoc comparisons on the PERMANOVA 3-way interaction term for treatment factor levels $(+\mathrm{AMB}$ and $+\mathrm{SAL})$ at each site during each sampling date.

\begin{tabular}{lll}
\hline Time & FW & BW \\
\hline Oct 2014 & $0.001^{* *}$ & $0.001^{* *}$ \\
Nov 2014 & $0.001^{* *}$ & 0.575 \\
Jun 2015 & $0.001^{* *}$ & $0.001^{* *}$ \\
Oct 2015 & $0.001^{* *}$ & 0.111 \\
\hline
\end{tabular}


Table 3-4. Indicator diatom taxa classified by multi-level pattern analysis (multipatt \{indicspecies $\}$ ) for control $(+\mathrm{AMB})$ and treatment $(+\mathrm{SAL})$ conditions at the freshwater $(\mathrm{FW})$ and brackish water (BW) marsh sites with mean relative abundance of each indicator species in each of the four groups.

\begin{tabular}{|c|c|c|c|c|c|c|}
\hline Taxa no. & Taxa & Authority & $\mathbf{F W}+\mathbf{A M B}$ & $\mathbf{F W}+\mathbf{S A L}$ & $\mathbf{B W}+\mathbf{A M B}$ & $\mathbf{B W}+\mathbf{S A L}$ \\
\hline & $\mathrm{FW}+\mathrm{AMB}$ & & & & & \\
\hline 1 & Achnanthes minutissima & Kützing 1833 & 0.077 & 0.044 & 0.000 & 0.000 \\
\hline 2 & Brachysira microcephela & (Grunow) Compère, 1986 & 0.402 & 0.348 & 0.183 & 0.153 \\
\hline 3 & Encyonema silesiacum elegans & Krammer, 1997 & 0.122 & 0.073 & 0.007 & 0.000 \\
\hline 4 & Encyonopsis microcephela & (Grunow) Krammer, 1997 & 0.703 & 0.637 & 0.017 & 0.000 \\
\hline 5 & Eunotia flexuosa & (Brébisson ex Kützing) Kützing,1849 & 0.052 & 0.014 & 0.000 & 0.004 \\
\hline 6 & Eunotia naegeli & Migula 1905 & 0.082 & 0.012 & 0.000 & 0.000 \\
\hline 7 & Gomphonema intricatum vibrio & (Ehrenberg) Cleve, 1894 & 0.195 & 0.103 & 0.077 & 0.089 \\
\hline 8 & Navicula cryptotenella & Lange-Bertalot, 1985 & 0.290 & 0.281 & 0.000 & 0.010 \\
\hline 9 & $\begin{array}{l}\text { Ulnaria delicatissima } \\
\mathrm{FW}+\mathrm{SAL}\end{array}$ & (W.Smith) Aboal \& Silva 2004 & 0.086 & 0.014 & 0.000 & 0.005 \\
\hline 10 & Encyonema evergladianum & Krammer, 1997 & 0.157 & 0.314 & 0.009 & 0.009 \\
\hline 11 & Encyonema mesianum & (Cholnoky) Mann, 1990 & 0.208 & 0.244 & 0.000 & 0.000 \\
\hline 12 & $\begin{array}{l}\text { Kobayasiella subtilissima } \\
\mathrm{BW}+\mathrm{AMB}\end{array}$ & Lange-Bertalot, 1999 & 0.051 & 0.053 & 0.000 & 0.000 \\
\hline 13 & Amphora sulcata & Brébisson, 1854 & 0.004 & 0.000 & 0.104 & 0.090 \\
\hline 14 & Caponea caribbea & Podzorski, 1984 & 0.000 & 0.000 & 0.069 & 0.065 \\
\hline 15 & Diploneis oblongella & (Nägeli ex Kützing) Cleve-Euler, 1922 & 0.005 & 0.024 & 0.213 & 0.194 \\
\hline 16 & Envekadea metezeltinii & Lee et al., 2013 & 0.000 & 0.000 & 0.080 & 0.061 \\
\hline 17 & Envekadea vanlandinghamii & Graeff, 2013 & 0.000 & 0.009 & 0.154 & 0.117 \\
\hline 18 & Fragilaria ftsp16 & & 0.010 & 0.004 & 0.297 & 0.252 \\
\hline 19 & Fragilaria minuscula & (Grunow) Williams,1987 & 0.005 & 0.005 & 0.119 & 0.073 \\
\hline 20 & Navicula bulnheimii & Grunow, 1863 & 0.000 & 0.000 & 0.032 & 0.015 \\
\hline 21 & Navicula cf. vmsp2 & & 0.000 & 0.000 & 0.077 & 0.078 \\
\hline 22 & Nitzschia acicularis & (Kützing) W.Smith, 1853 & 0.000 & 0.000 & 0.047 & 0.041 \\
\hline 23 & Nitzschia ftspl6 & & 0.015 & 0.000 & 0.199 & 0.078 \\
\hline 24 & Nitzschia microcephela & Grunow, 1880 & 0.000 & 0.000 & 0.026 & 0.010 \\
\hline 25 & Nitzschia nana & Grunow in Van Heurck, 1881 & 0.031 & 0.031 & 0.099 & 0.105 \\
\hline 26 & Planothidium rostratum & (Østrup) Lange-Bertalot 1999 & 0.000 & 0.000 & 0.026 & 0.010 \\
\hline 27 & Seminavis pusilla & (Grunow) Cox \& Reid, 2004 & 0.005 & 0.015 & 0.299 & 0.233 \\
\hline 28 & Stephanocyclus menghiniana & Kützing ,1844 & 0.016 & 0.030 & 0.101 & 0.090 \\
\hline 29 & $\begin{array}{l}\text { Synedra filiformis exilis } \\
\mathrm{BW}+\mathrm{SAL}\end{array}$ & Cleve, 1939 & 0.007 & 0.020 & 0.111 & 0.087 \\
\hline 30 & Amphora acutiuscula & Kützing, 1844 & 0.000 & 0.007 & 0.103 & 0.111 \\
\hline 31 & Amphora coffeaeformis aponina & Archibald \& Schoeman, 1984 & 0.006 & 0.000 & 0.106 & 0.143 \\
\hline 32 & Amphora montana & Krasske 1932 & 0.000 & 0.004 & 0.026 & 0.048 \\
\hline 33 & Amphora punctata & Stepanek and Kociolek 2013 & 0.004 & 0.000 & 0.200 & 0.225 \\
\hline 34 & Amphora veneta & Kützing, 1844 & 0.000 & 0.000 & 0.064 & 0.120 \\
\hline 35 & Caloneis bacillum & (Grunow) Cleve 1894 & 0.004 & 0.000 & 0.016 & 0.065 \\
\hline 36 & Fragilaria synegrotesca & Lange-Bertalot, 1993 & 0.223 & 0.120 & 0.247 & 0.288 \\
\hline 37 & Mastoglogia pseduosmithii & Lee et al., 2014 & 0.000 & 0.000 & 0.039 & 0.071 \\
\hline 38 & Mastogloia braunii & Grunow, 1863 & 0.000 & 0.000 & 0.070 & 0.095 \\
\hline 39 & Mastogloia lanceolata & Thwaites ex W.Smith 1856 & 0.011 & 0.011 & 0.317 & 0.319 \\
\hline 40 & Navicula salinicola & Hustedt, 1939 & 0.004 & 0.007 & 0.143 & 0.180 \\
\hline 41 & Pleurosigma salinarum & (Grunow) Grunow, 1880 & 0.000 & 0.000 & 0.013 & 0.023 \\
\hline 42 & Rhopalodia pacifica & Lange-Bertalot \& Krammer, 1987 & 0.000 & 0.004 & 0.059 & 0.161 \\
\hline
\end{tabular}


Figure 3-1. Reference map of Everglades National Park, Florida, USA (A) and the location of freshwater (FW) and brackish (BW) marsh sites within the park (B). Image of the experimental chambers used to enclose a plot of marsh from where samples and environmental measurements were taken $(\mathrm{C})$. Diagram showing the experimental design layout (D). Blue circles represent control (+AMB) chambers and green circles represent the salinity treatment $(+\mathrm{SAL})$ chambers.

A.

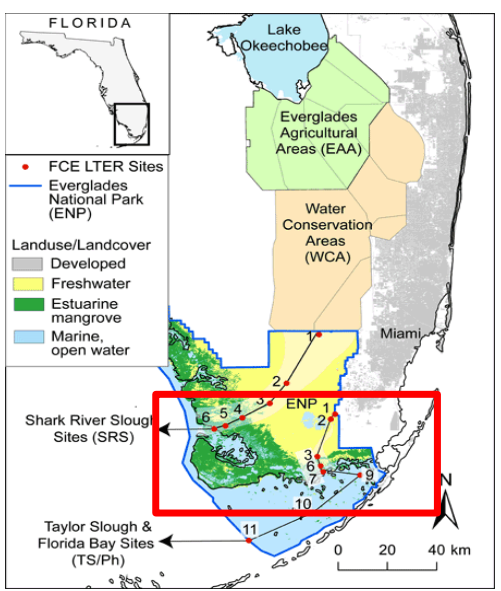

C.

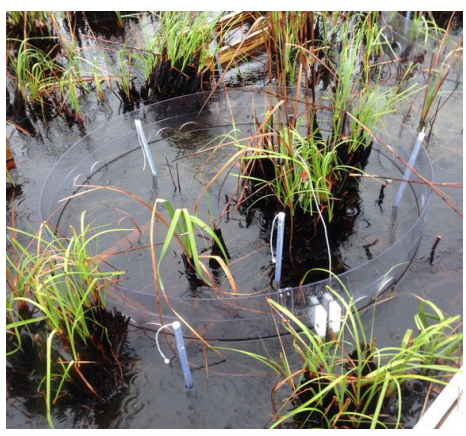

B.

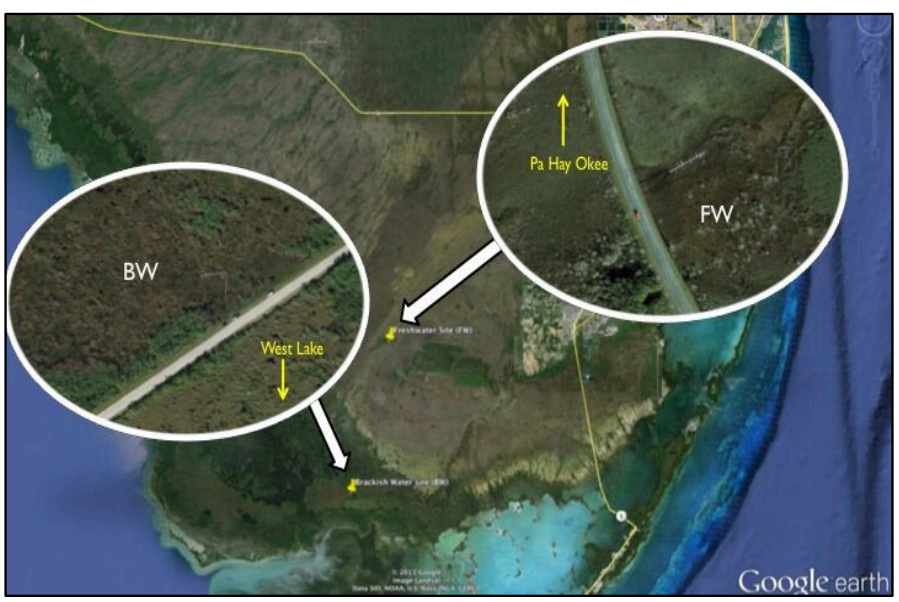

D.

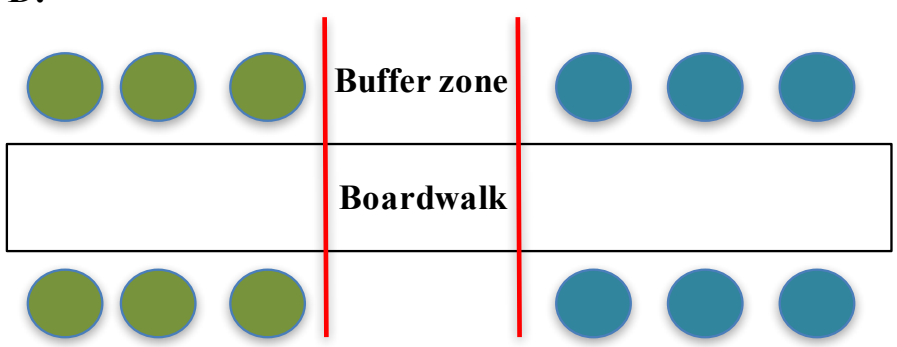


Figure 3-2. Mean surface water and porewater salinity in control (+AMB) and treatment (+SAL) plots at the freshwater (A) and brackish water $(\mathrm{B})$.

Aa.

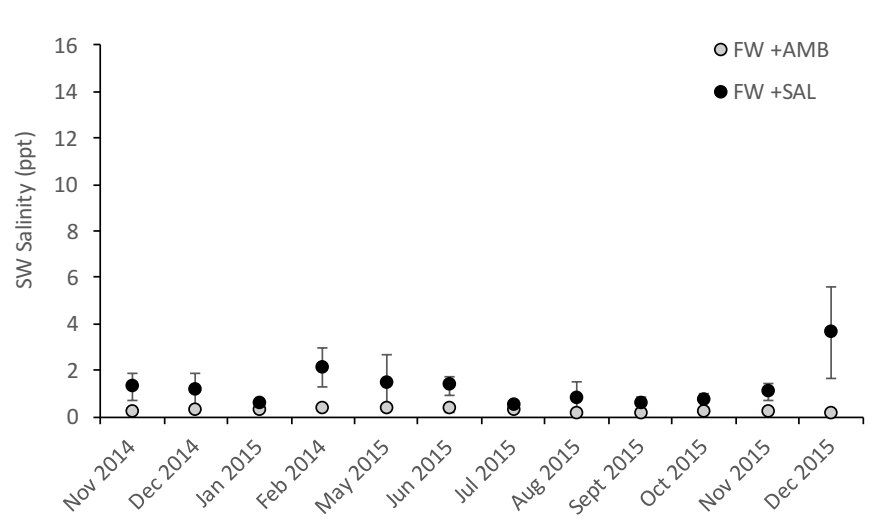

Ab.

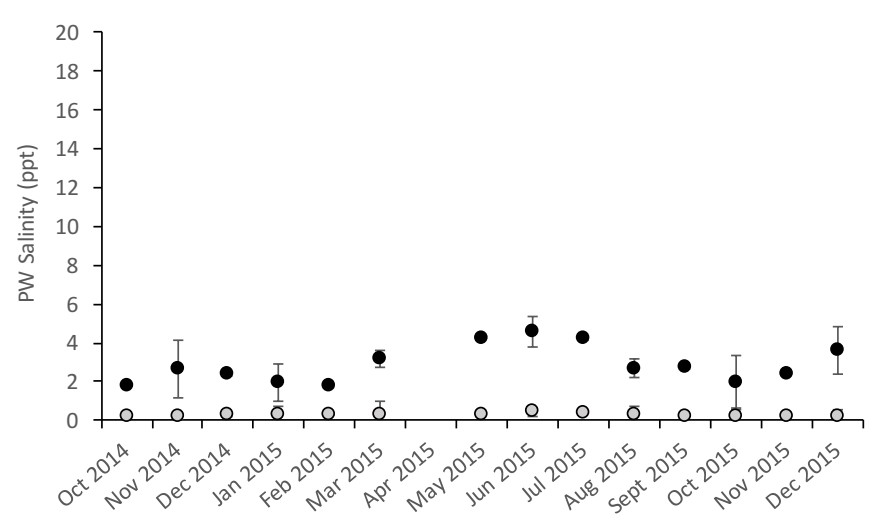

Ba.

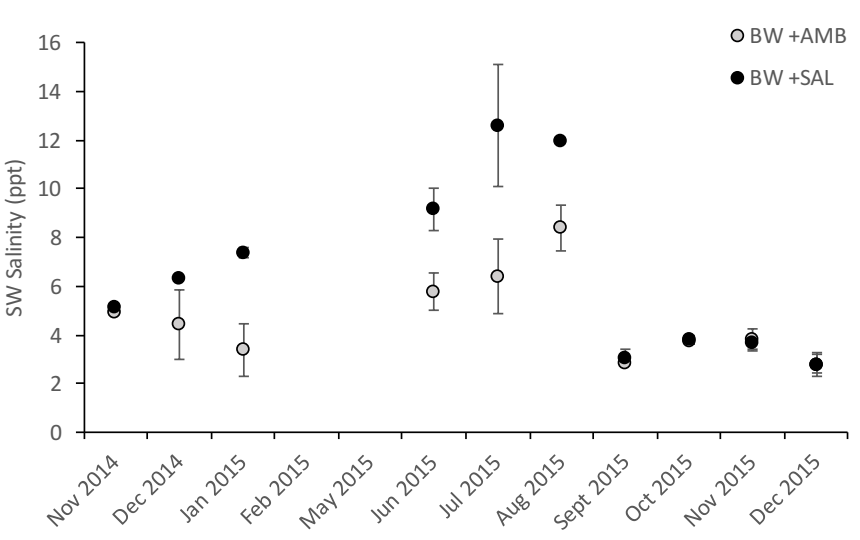

Bb.

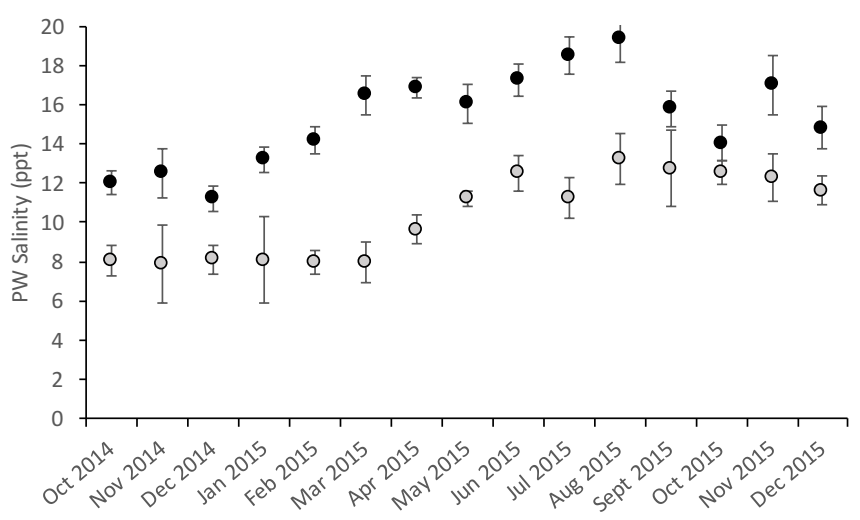


Figure 3-3. Periphyton metabolism (net ecosystem productivity, NEP; ecosystem respiration, ER; and gross primary productivity, GPP), periphyton carbon content (total carbon, TC; organic carbon, OC; and inorganic carbon, IC), periphyton total nitrogen $(\mathrm{TN})$, and periphyton total phosphorous (TP) in control (+AMB) and treatment (+SAL) plots at the freshwater (A) and brackish water (B) sites in order from top to bottom. Asterisk represent significant treatment effects within each sampling date.

Aa.

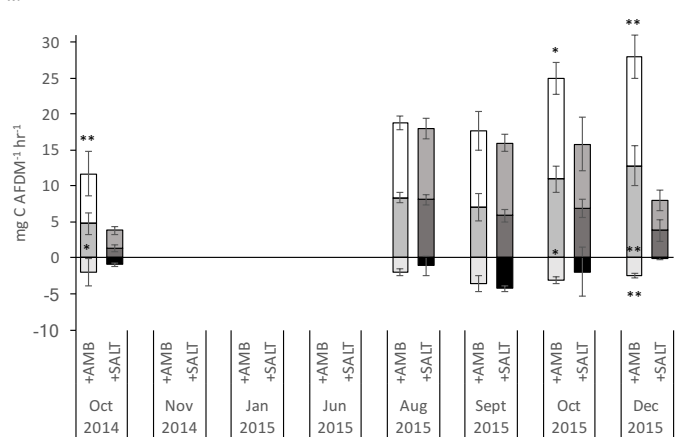

Ab.
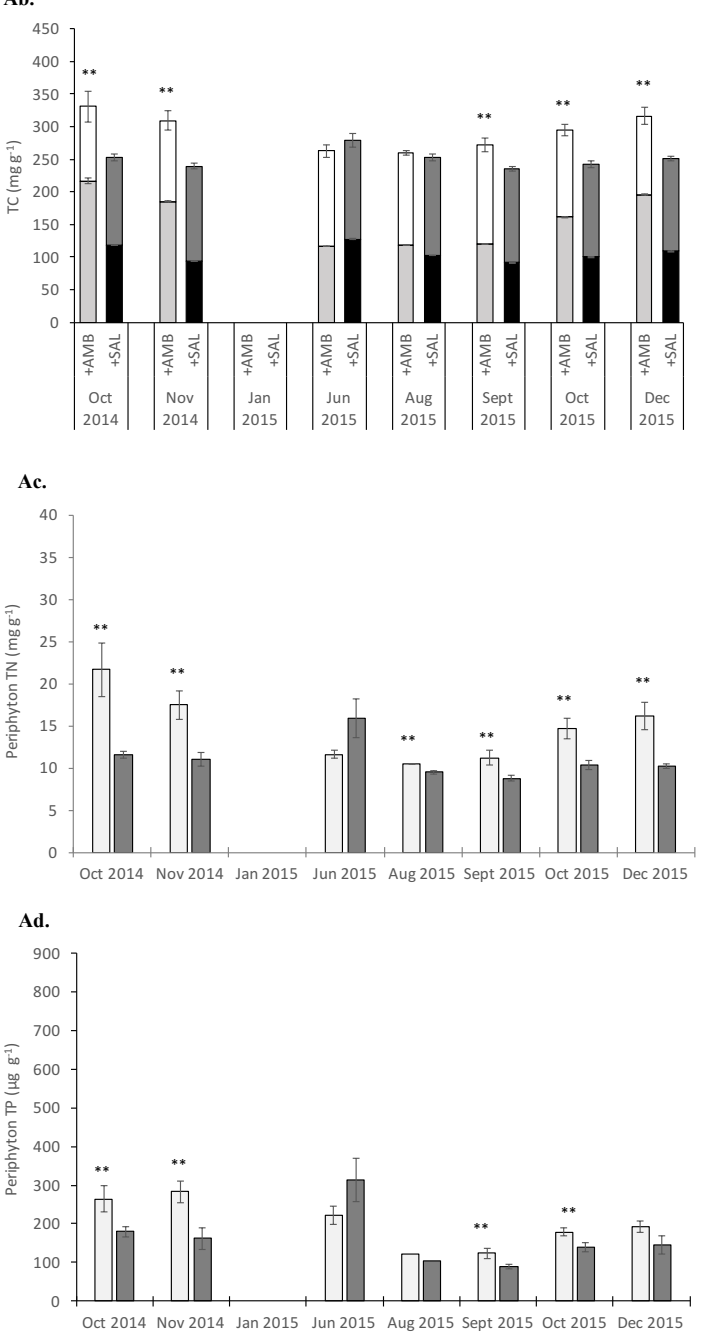

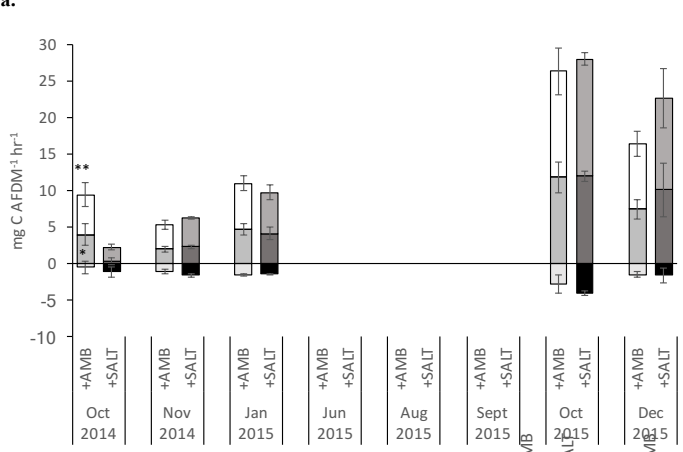

Bb.

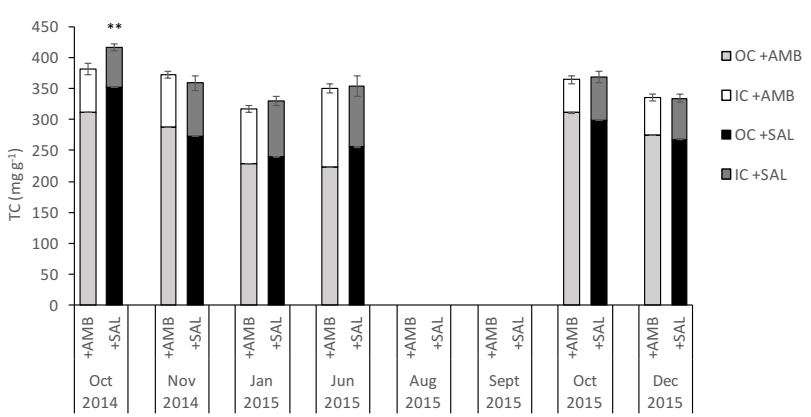

Bc.
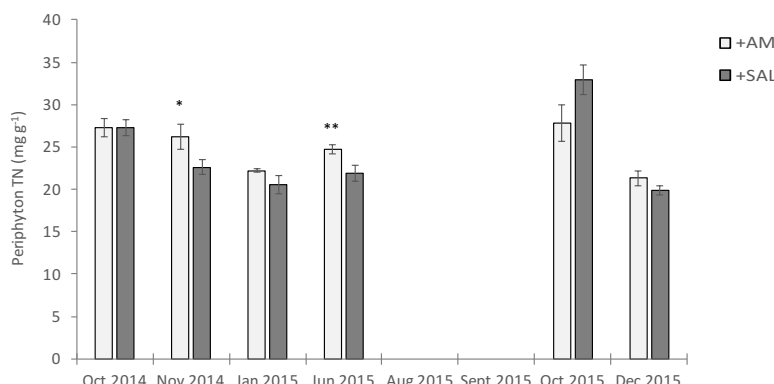

Bd.

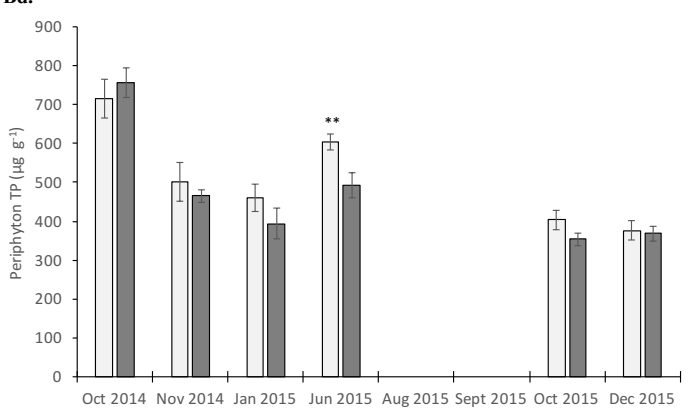

$\square G P P+S A L$ - ER +SAL

$\square N E P+S A L$ $\square G P P+A M B$ $\triangle E R+A M B$ $\square N E P+A M B$
$\square+S A L$ 
Figure 3-4. Nonmetric multidimensional scaling (NMDS) ordinations (left) and analysis of similarity (ANOSIM) boxplots showing ranked species dissimilarity within and between groups (right). Freshwater (FW) and brackish (BW) diatom assemblages were highly dissimilar throughout the experiment (top). Diatom assemblages were significantly different between control (+AMB) and treatment (+SAL) plots at the freshwater (center) and brackish water (bottom) site. Dispersion was greater within the +SAL treatment group compared to the $+\mathrm{AMB}$ group for both the $\mathrm{FW}$ and $\mathrm{BW}$.

Aa.

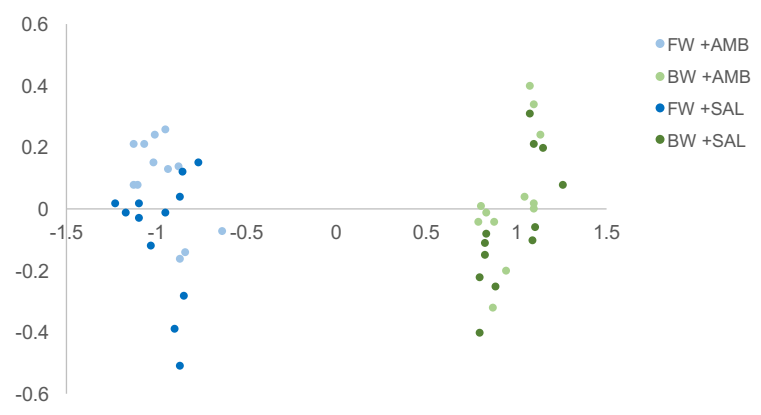

Ab.

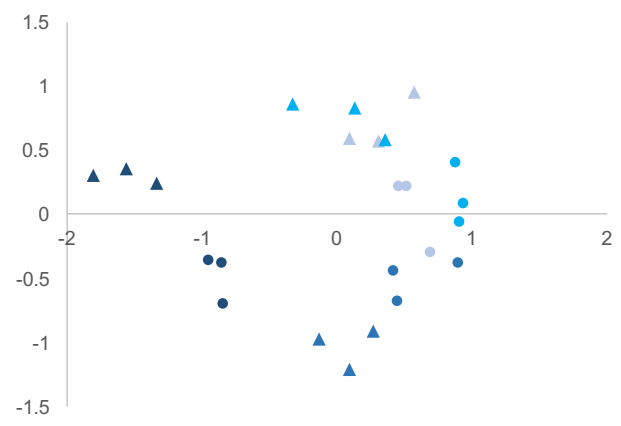

Ac.

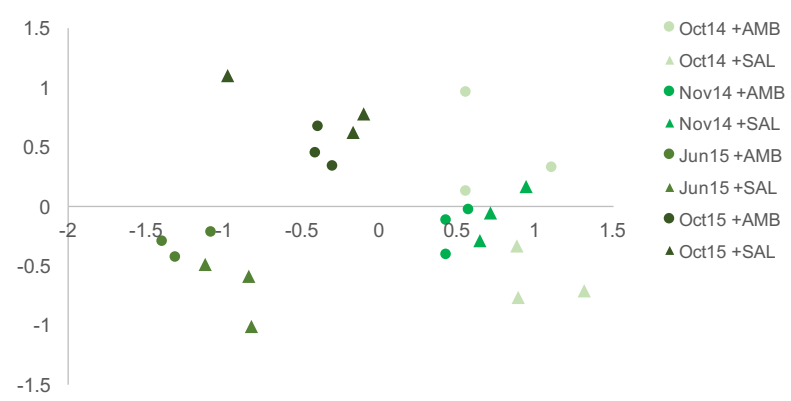

Ba.

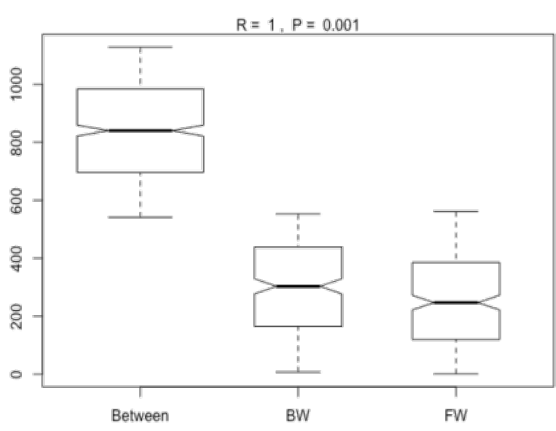

Bb.

- Oct14 +AMB $\triangle$ Oct14 +SAL - Nov14 +AMB $\triangle$ Nov14 +SAL - Jun15+AMB \ Jun $15+$ SAL - Oct15 +AMB act15 +SAL

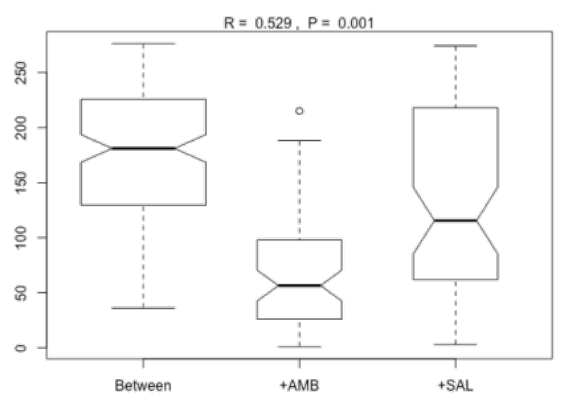

Bc.

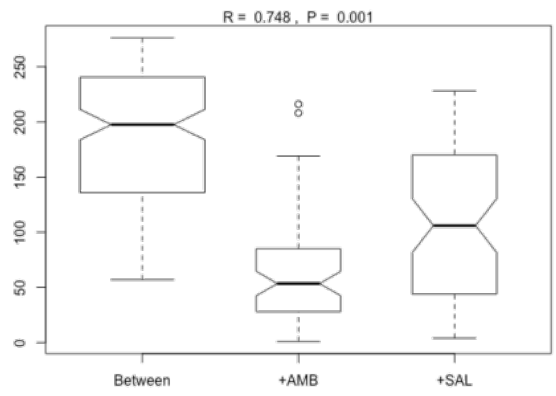


Figure 3-5. Indicator taxa plates for freshwater + AMB (A), freshwater + SAL (B), brackish water $+A M B(C)$ and brackish water + SAL (D) conditions. Image numbers correspond to taxa number in table 3.
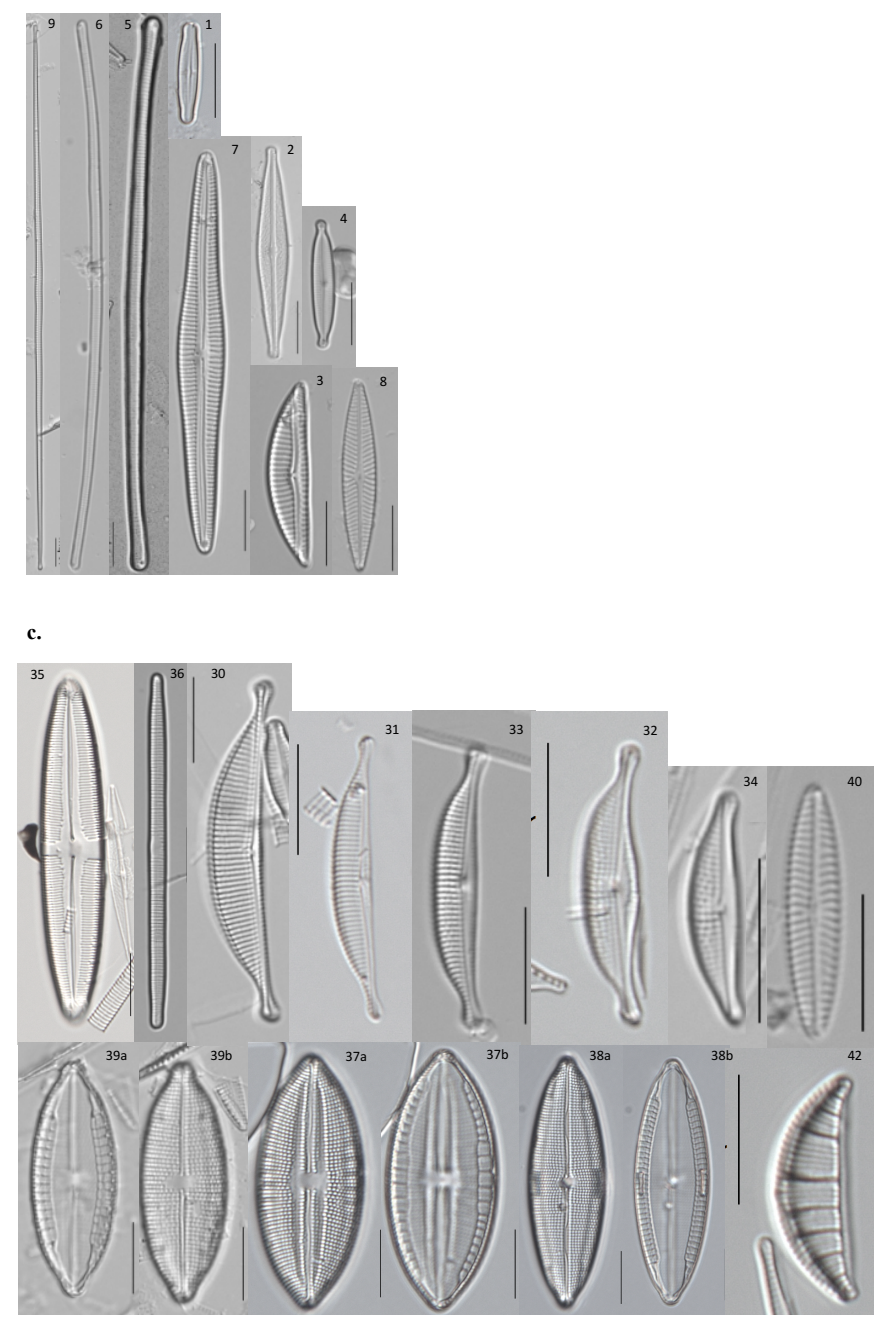
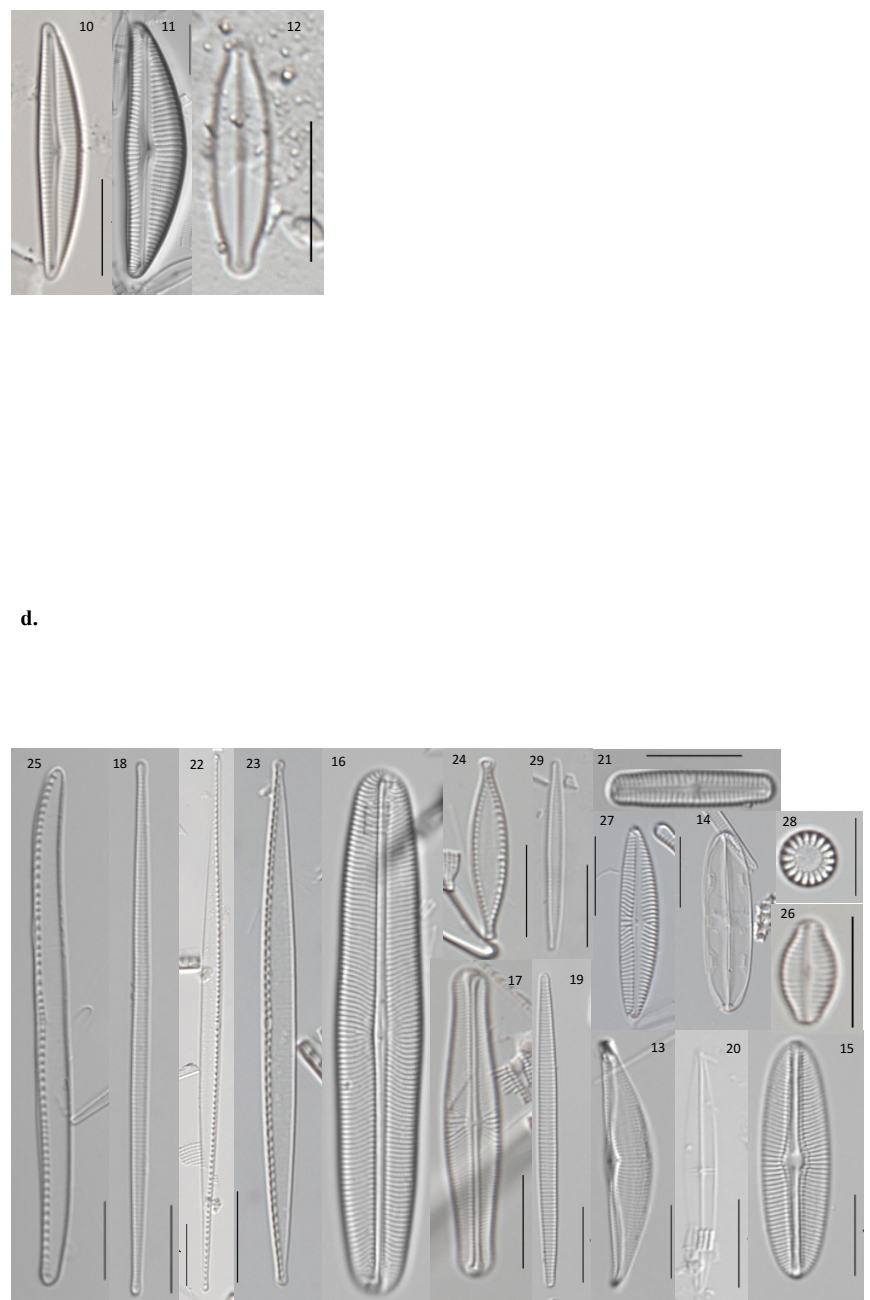


\title{
CHAPTER IV
}

\section{PERIPHYTON FUNCTIONAL AND COMPOSITIONAL RESPONSE TO INDIVIDUAL AND SYNERGISTIC EFFECTS OF EXPERIMENTALLY ELEVATED SALINITY AND PHOSPHORUS.}

\begin{abstract}
The karstic wetlands located near coastlines in the Caribbean Basin are particularly susceptible to saltwater intrusion and coastal transgression because of their porous carbonate bedrock and low elevation relative to sea level. Saltwater intrusion elevates salinity and phosphorus (P) availability in these naturally freshwater, P-limited wetlands and is expected to alter biogeochemical cycles along with the structure and function of plant and algal communities. Calcareous periphyton - microbial assemblages of matforming and calcium carbonate precipitating algae and bacteria - is considered an important ecosystem engineer in karstic wetlands and is very sensitive to water quality changes. We conducted an ex situ mesocosm experiment to test the individual and cumulative effects of elevated salinity and $\mathrm{P}$ on the productivity, nutrient uptake, and diatom assemblage composition of freshwater, calcareous periphyton. Productivity was measured as ash-free dry mass and biomass specific chlorophyll- $a$ accumulation rates on settlement plates. A one-time metabolism assay was conducted in which periphyton gross primary productivity, net ecosystem productivity, and ecosystem respiration were measured using the light and dark bottle method. We measured the total carbon, nitrogen and phosphorus content and analyzed the diatom species composition of periphyton samples collected from each treatment. We observed patterns of reduced productivity, total
\end{abstract}


carbon, and nutrient uptake in freshwater periphyton exposed to saltwater. However, the addition of $\mathrm{P}$ to freshwater mats tended to increase chlorophyll- $a$ and nutrient content while having no significant effect on productivity or total carbon content. Similar patterns were observed for salt-treated mats with added phosphorus, although these mats had significantly higher gross primary productivity and net ecosystem productivity compared to mats treated only with salinity. We found significant dissimilarity in diatom composition between fresh- and saltwater treated mats. Freshwater mats treated with P did not exhibit significantly different diatom assemblages compared to freshwater mats; however, two diatom species were recognized as significant indicators of enriched freshwater conditions. The addition of $\mathrm{P}$ to salt-treated mats did cause significant taxonomic divergence and indicator taxa of enriched saltwater conditions were also identified. This study is one of the few to experimentally examine the individual and combined effects of elevated salinity and $\mathrm{P}$ on wetland periphyton and provide indicator species that can used to assess salinity and $\mathrm{P}$ fluctuations caused by saltwater intrusion. This research provides valuable information regarding periphyton dynamics in response to changing water sources that will allow us to extend the use of periphyton, and their diatom assemblages, as tools for environmental assessments related to saltwater intrusion in the southern Everglades and other karstic, freshwater wetlands. 


\section{INTRODUCTION}

The karstic, freshwater wetlands located near tropical and subtropical coasts in the Caribbean Basin are particularly susceptible to saltwater intrusion driven by sea level rise and local water management outcomes. These wetlands are characterized by a porous carbonate bedrock and low elevations relative to sea level making then exceptionally vulnerable to saltwater intrusion and coastal transgression. Saltwater intrusion into freshwater, karstic wetlands, such as the Florida Everglades, alters biogeochemical processes that affect ecosystem carbon and nutrient cycling (Weston et al. 2011, Chambers et al. 2014, Williams et al. 2014, Herbert et al. 2015) and modifies environmental conditions to favor coastal communities (James et al. 2003, Ross et al. 2000, Troxler et al. 2014). The ecological and socio-economic value of coastal, freshwater wetlands are motivating factors to understand the ecological effects of saltwater intrusion on these vulnerable ecosystems.

Saltwater intrusion is largely driven by climate change and can be exacerbated by water management practices that alter natural freshwater flows into downstream marshes (Saha et al. 2011, Briceno et al. 2014, Herbert et al. 2015). The Florida Everglades is a perfect example of a karstic, freshwater wetland severely threatened by saltwater intrusion due to sea level rise, particularly in the absence of large-scale restoration of freshwater supplies. Historical drainage and channelization of Everglades marshes have lessened freshwater flow into the southern Everglades leading to reduced groundwater and aquifer recharge in this region (Davis et al. 2005, McVoy et al. 2011, McCormick et al. 2011). The resulting decrease in water table depth causes saltwater to intrude further into the aquifer, 
increasing ground- and porewater salinities. A lower water table also allows overland saltwater intrusion, particularly during storm surges. In addition to elevated salinity, marine water intrusion exposes freshwater marshes to changes in ionic concentration that can alter natural biogeochemical cycles and influence plant and algal productivity. For example, saltwater intrusion increases phosphorus $(\mathrm{P})$ availability in the naturally P-limited karstic, freshwater wetlands (Williams et al. 2014). These systems have been described as "up-side down" because, unlike most estuaries, $\mathrm{P}$ concentrations are higher in coastal wetlands compared to interior freshwater marshes, and marine water is the dominant source of $\mathrm{P}$ to southern Everglades freshwater marshes, especially those adjacent to the Gulf of Mexico (Childers et al. 2006). The intrusion of marine water through the limestone bedrock introduces a second source of $\mathrm{P}$ as saltwater causes $\mathrm{CaCO}_{3}$-bound $\mathrm{P}$ to be desorbed and made biologically available (Price et al. 2006). Successful assessments and mitigation strategies of saltwater intrusion into the Everglades requires an understanding of how key ecosystem components, including plants, soil microbes, and periphyton, respond to the simultaneous salinity stress and P subsidies provided by saltwater intrusion.

Calcareous periphyton mats are an important and abundant component of the Florida Everglades and other karst, freshwater wetlands in the Caribbean Basin (Gaiser et al. 2011, La Hee and Gaiser 2012, Komarek et al 20XX. Periphyton is characterized as a microbial assemblage of diatoms, cyanobacteria, chlorophytes and other microorganisms surrounded by a matrix of mucilage and interstitial calcium carbonate secreted by certain resident algal species (Azim and Asaeda 2005, Hagerthey et al. 2011). Periphyton provides a unique microhabitat for a variety of autotrophic and heterotrophic organisms and plays important roles in food web dynamics, organic and inorganic carbon cycling, nutrient 
cycling, and marl soil (calcium carbonate mud) formation (Davis 1994, Rejmankova and Komarkova 2000, Hagerthey et al. 2011, Gaiser et al. 2011, La Hee and Gaiser 2012, Schedlbauer et al. 2012, Troxler et al. 2013, Trexler et al. 2015). Furthermore, periphyton is exceptionally sensitive to water quality changes and responds with shifts in species composition that in turn affect the physical structure and ecological roles of these mats (McCormick et al. 2001, Gasier et al.2006, Gaiser et al. 2011, Hagerthey et al. 2011). Because of their environmental sensitivity, these mats are often used as bioindicators in ecological assessments of wetland water quality (P loading) and quantity (hydroperiod) (McCormick 1998, Gaiser et al. 2009). However, not much is known about how these mats respond to the increased salinity and changes in water chemistry, particularly $\mathrm{P}$ availability, caused by saltwater intrusion.

The diatom assemblages of periphyton are commonly used as ecological indicators of water quality in the Everglades. Diatoms are particularly sensitive to changing abiotic conditions given their environmental specificity and quick response times (Stevenson et al. 1999, Potapova and Charles 2007, Desrosiers et al. 2013, Stevenson 2014). Furthermore, diatoms are relatively easy to identify compared to cyanobacteria and chlorophytes because of their species-specific cell wall ornamentation which can be discerned under light microscopy. Aside from their indicator value, many periphytic diatoms contribute to mat formation and cohesion through the production of extracellular mucilage and attachment structures (Johnson and Tuchman 1997, Azim and Asaeda 2005, Lee et al. 2014). Therefore, shifts in the composition and relative abundances of diatoms, and other matengineering species (e.g., cyanobacteria), are associated with different periphyton mat types, such as biofilms or filamentous mats (Vymazal et al. 1995, McCormick and O’Dell 
1996, Pan et al. 2000, Rejmankova and Komarkova 2005, Gaiser et al. 2006, Hagerthey et al. 2011, Gaiser et al. 2011). Diatoms not only provide a useful tool to assess changing salinity and $\mathrm{P}$ conditions related with saltwater intrusion, but can serve as indicators of changes in periphyton mat structure caused by increased salinity and $P$.

Exposure of aquatic plants and algae to elevated salinity induces physiological stress responses that can be expressed as morphological changes, nutrient-uptake limitations, reduced productivity, and ultimately death (Alam, 1999, Mendelssohn et al. 2006, Touchette 2007, Affenzeller et al. 2009, Trobajo et al. 2011). Organism-level responses to salt stress eventually translate to community-scale changes with consequences to ecosystem structure and function (Ross et al. 2000, James et al. 2003, Troxler et al. 2014). The simultaneous exposure of freshwater periphyton to salt stress and P-subsidy, as is expected with saltwater intrusion, may trigger complicated and counterintuitive responses from freshwater, calcareous periphyton. While nutrient enrichment is generally associated with increased algal growth (Elser et al. 2007) and is expected to ameliorate disturbance stress (Odum et al. 1979), the calcareous periphyton mats of karstic wetlands thrive under P-limitation and respond negatively to P loading. For example, the compact, calcareous periphyton found throughout the short-hydroperiod marshes of the Everglades have been shown to breakdown when exposed to increased P (McCormick et al. 2001, Gaiser et al. 2006). Although the exact mechanisms behind periphyton breakdown with $P$ enrichment remain poorly understood, there is plenty of evidence demonstrating that $\mathrm{P}$ causes changes in mat structure and shifts in species composition that result in replacement of native mats by eutrophic biofilms and filamentous mats that do not provide the same ecological services as calcareous, cohesive periphyton (Vymazal et al. 1995, McCormick 
and O’Dell 1996, Pan et al. 2000, Rejmankova and Komarkova 2005, Gaiser et al. 2006, Hagerthey et al. 2011, Gaiser et al. 2011). Therefore, the combination of elevated salinity and $\mathrm{P}$ availability caused by saltwater intrusion theoretically represents a two-fold stress on native Everglades periphyton mats.

In this study, we examined the individual and combined effects of elevated salinity and $\mathrm{P}$ on the productivity, total carbon, nitrogen, and phosphorus content, and diatom assemblages of the calcareous, freshwater periphyton of the Florida Everglades. An outdoor mesocosm experiment was conducted in which sawgrass cores with benthic periphyton were treated with factorial combinations of salinity and P (freshwater only, freshwater with added $\mathrm{P}$, saltwater only, and saltwater with added P). We proposed three general hypotheses: 1) Mats exposed to the salt only treatments would respond with reduced productivity, chlorophyll-a, and total carbon, nitrogen, and phosphorus content compared to freshwater controls due to salt stress. These functional responses would be accompanied by significant taxonomic dissimilarity between diatom assemblages from control (fresh) and salt-treated mats, reflecting a shift from freshwater species to ones with greater salt tolerances. 2) The addition of $\mathrm{P}$ to freshwater periphyton would trigger increased productivity, chlorophyll-a, total nitrogen and total $\mathrm{P}$ content compared to controls as calcareous periphyton becomes replaced by eutrophic mats or biofilms that would have lower total carbon content and AFDM accumulation rates. Periphytic diatom assemblages would reflect these functional changes with taxonomic shifts towards eutrophic species not typically associated with calcareous mats. 3) The addition of P to salt-treated periphyton would increase productivity, chlorophyll-a, total nitrogen and total $\mathrm{P}$ content, while reducing the total carbon and AFDM accumulation rates, compared to 
salt-treated mats without $\mathrm{P}$ inputs as calcareous periphyton mats become replaced by noncohesive mats composed of salt-tolerant, eutrophic species. Diatom assemblages in mats treated with elevated salinity and $\mathrm{P}$ would be significantly dissimilar from mats treated with salt only, but would be more similar to this assemblage than to either the P-treated freshwater mats or control freshwater mats.

\section{METHODS}

An outdoor mesocosm experiment was conducted at the Florida Bay Interagency Science Center (FBISC) in Key Largo, Florida to test the response of calcareous periphyton mats from oligotrophic, freshwater marshes to combinations of elevated salinity and $\mathrm{P}$. Twenty-four sawgrass cores with intact periphyton were collected on July 2014 from a freshwater marsh in the Florida Everglades $\left(25^{\circ} 46^{\prime} 06.1^{\prime \prime} \mathrm{N}, 80^{\circ} 28^{\prime} 56.2^{\prime \prime} \mathrm{W}\right)$ and transported to FBISC in perforated plastic buckets $(0.3 \mathrm{~m} \mathrm{D} \times 0.4 \mathrm{~m} \mathrm{~W} \times 0.5 \mathrm{~m} \mathrm{~L})$ lined with mesh. Each core was placed within a larger plastic container $(0.5 \mathrm{~m} \mathrm{D} \times 0.5 \mathrm{~m} \mathrm{~W} \times 0.7 \mathrm{~m} \mathrm{~L})$, four of which were then placed in one of 6 concrete crypts $(0.7 \mathrm{~m} \mathrm{D} \times 0.8 \mathrm{~m} \mathrm{~W} \times 2.2 \mathrm{~m} \mathrm{~L})$ filled with freshwater from the C-111 (Figure 1A). This canal was located near the research facility and had similar water chemistry as water from the harvest site. The four cores in each crypt were individually contained and separated by plastic dividers to avoid contamination. The sawgrass cores were allowed 8 months to equilibrate before beginning the experiment at the end of March 2015. However, by this time much of the periphyton collected with the cores had been lost due to transportation and experimental setup, as well as sawgrass overgrowth that caused excessive shading of the periphyton mats. Therefore, 
before beginning the experiment we pruned dead leaves from the sawgrass plants and reseeded each core with fresh periphyton collected from the site where the cores were harvested (Figure 1B).

The experimental design consisted of a factorial array of 4 treatments with 6 replicates each: freshwater control (F), freshwater with P (FP), saltwater (S), and saltwater with P (SP) (Figure 1C). Each crypt was randomly assigned an F or S treatment. The F crypts received twice weekly manual additions of freshwater collected from the nearby C111 canal to maintain water levels above the soil surface. The $\mathrm{S}$ crypts received twice weekly manual additions of a brine solution with a known salinity to raise or maintain the salinity in the crypts to the target concentration of $10 \mathrm{ppt}$. The brine solution consisted of freshwater from the C-111 canal mixed with Florida Bay seawater collected from the dock behind FBISC. Two of the four cores within each crypt were assigned a P treatment which consisted of continuously delivering $2.25 \mathrm{mg} \mathrm{L}^{-1}$ of diluted phosphoric acid at $0.14 \mathrm{~mL}$ $\min ^{-1}$ using two multichannel peristaltic pumps with six lines each $(n=12$, Ismatec, Weirtheim, Germany). Surface and pore water temperature, $\mathrm{pH}$, and salinity in each core was measured weekly using a YSI Model 600 XL (Xylem, Inc., Yellow Springs, OH, USA). Total phosphorus (TP) in the surface water was measured monthly using an Alpkem RFA 300 auto-analyzer (OI Analytical, College Station, TX, USA).

We deployed $4 \times 4$ inch plexiglass settlement plates in each core to measure periphyton biomass and chlorophyll-a accumulation rates and to analyze diatom species composition. The settlement plates were incubated on the soil surface of the sawgrass cores for two months. At the end of the two-month incubation period, settlement plates were retrieved and transported to the laboratory where they were scrapped clean using a razor 
blade and deionized water. Settlement plates were sterilized using a bleach solution and redeployed the following month. The was done quarterly from March 2015 to April 2016 for a total of 4 settlement plate samples.

The material scraped from the settlement plates was collected in a beaker and homogenized with deionized water (DI) water to a minimum volume of $200 \mathrm{mls}$. The beaker was placed on a stir plate to facilitate continuous mixing while the slurry was subsampled for biomass, chlorophyll- $a$, and diatom analysis. The biomass subsample was placed in a drying oven at $80^{\circ} \mathrm{C}$ for $\geq 48 \mathrm{~h}$ to obtain a dry mass (g) measurement and then in a furnace where it was combusted at $500^{\circ} \mathrm{C}$ for $1 \mathrm{~h}$ to obtain the ash (mineral) mass (g). We calculated ash-free dry mass (AFDM) by the loss-on-ignition method as the difference between the ash mass and the total dry mass. The chl-a subsample was filtered onto Whatman $25 \mathrm{~mm}$ glass fiber filter (GFF) paper, frozen, and later subjected to $48 \mathrm{~h} 90 \%$ cold acetone extraction at $20 \mathrm{C}$. Chl-a concentration was determined by flourometry using a Gildford FLUORO IV (Gilford Instrument, Oberlin, $\mathrm{OH}$; excitation $435 \mathrm{~nm}$; emission $667 \mathrm{~nm}$ ). AFDM and chl- $a$ accumulation rates $\left(\mathrm{mg} \mathrm{m}^{-2} \mathrm{~d}^{-1}\right)$ were calculated by standardizing AFDM and chl- $a$ values by the area of the settlement plates and the number of days incubated.

Diatom subsamples were cleaned of mineral debris and organic matter using the sulfuric acid oxidation methods prescribed by Hasle and Fryxell (1970). We pipetted a known volume of cleaned diatom samples onto a glass coverslip, permanently mounted them it on a microscope slide with Naphrax (PhycoTech Inc., St. Joseph, Michigan) mounting medium, and viewed the diatoms under a compound light microscope (Zeiss Axioskop 2) equipped with differential interference contrast and a Leica DFC425 digital camera. We counted at least 500 valves along random transects at $600 \times$ magnification 
under oil immersion and identified them to the species level. Raw diatom counts were converted to relative abundance by standardizing the number of valves counted for each species by the total number of valves counted.

On the dates of settlement plates deployment and retrieval, we also collected $10 \mathrm{ml}$ periphyton plugs from each sawgrass core using a $7.1 \mathrm{~cm}^{2}$ diameter plastic syringe. In the lab, the plugs were placed in a 500-mL beaker and homogenized with deionized water (DI) water to a periphyton slurry with a minimum volume of $200 \mathrm{mls}$. The beaker was placed on a stir plate to facilitate continuous mixing while the slurry was subsampled for biomass, chlorophyll- $a$, total carbon (TC), total nitrogen (TN), and total phosphorus (TP) analyses. The biomass and chlorophyll- $a$ subsamples were analyzed using the same methods described above for the settlement plate samples. The TP subsample was dried at $80^{\circ} \mathrm{C}$ and pulverized with a mortar and pestle. We processed a known amount of each subsample and used colorimetric analysis to estimate TP concentration, expressed as $\mu \mathrm{g} \mathrm{g} \mathrm{AFDM}^{-1}$, following the methods of Solorzano and Sharp (1980). TC and TN subsamples were ground down to a fine powder by mortar and pestle, dried at $60^{\circ} \mathrm{C}$, and analyzed for total $\mathrm{C}$ and $\mathrm{N}$ content using a Flash 1112 elemental analyzer (CE Elantech) following standard procedures.

Periphyton net ecosystem productivity (NEP), ecosystem respiration (ER), and gross primary productivity (GPP) were measured in February 2016 using the light and dark bottle technique to measure biological oxygen demand (BOD). Two $10 \mathrm{ml}$ periphyton samples were collected from each core - one was placed in a clear bottle to measure periphyton NEP and the other was placed in a dark bottle to measure periphyton ER. The paired clear and dark BOD bottles for each core were filled with source water and initial 
oxygen concentrations were measured. The bottles were topped off with source water before capping the bottles to avoid air bubbles. The bottles were then submerged in a water bath where they incubated for 2 hours under ambient conditions. After the incubation period, final oxygen concentrations were measured and the periphyton from the light bottles was transported back to the lab for further analyses as described above. NEP and ER were standardized to the ash-free dry mass (AFDM) of the incubated sample and the measured oxygen production and consumption rates were converted to mg C g $\mathrm{AFDM}^{-1}$ $\mathrm{hr}^{-1}$ by multiplying NEP and ER by the mass ratio of C: $\mathrm{O}_{2}(0.357)$. and then dividing NEP by a photosynthetic quotient of 1.2. and ER by a respiratory quotient of 1 (Knapp et al. 2007). GPP was then calculated by subtracting ER from NEP.

We assessed the magnitude and statistical significance of the salinity and $\mathrm{P}$ additions by univariate analysis of variance (ANOVA) and Tukey post-hoc test to determine if we had significantly elevated salinity in S compared to F treatments and TDP in $\mathrm{FP}$ and $\mathrm{SP}$ compared to $\mathrm{F}$ and $\mathrm{S}$ treatments. Multivariate analysis of variance (MANOVA) was used to assess differences in periphyton functional responses across treatments (IBM SPSS Statistics V23.0). A one-way MANOVA was used to statistically compare the response of chl-a, $\mathrm{TC}, \mathrm{TN}$, and $\mathrm{TP}$ concentrations in the periphyton plugs to each of the four treatment conditions across the 7 sampling dates. Post-hoc pairwise comparisons (Tukey) were used to determine significant differences among treatments and estimated marginal means were plotted to visualize overall treatment differences. This same method was used to test treatment effects on AFDM and Chl-a accumulation rates from the settlement plates. The one-time (Feb 2016) metabolism measurements (NEP, ER, GPP) were also analyzed using MANOVA and a Tukey post-hoc test. Diatom 
compositional dissimilarity (settlement plates) among treatments was analyzed by analysis of similarity (ANOSIM). Non-metric multidimensional scaling (NMDS) was used to visualize Bray-Curtis dissimilarity among treatment groups (PRIMER v6). Indicator species for each treatment group and combinations of treatment groups were determined using the multi-level pattern analysis available in the indicspecies package (multipatt \{indicspecies\}) in R (De Cáceres 2013, De Cáceres et al. 2010).

\section{RESULTS}

$\underline{\text { Saltwater and phosphoric acid additions }}$

The addition of saltwater significantly elevated surface water salinity in the S (7.3 ppt) and SP (7.2 ptt) treatments compared to the F ( $0.5 \mathrm{ppt})$ and FP (0.4 ppt) treatments across all sampling dates and on all individual sampling dates (Table 1, Figure 2A). Salinity in both freshwater (F and FP) and both saltwater ( $\mathrm{S}$ and $\mathrm{SP}$ ) treatments were nearly identical throughout the experiment. Salinity in the two freshwater treatments remained steady throughout the experiment, while the salinity treatments fluctuated over time and experienced higher than average salinity during summer months (May - Aug 2015). Although the addition of phosphoric acid elevated mean $(n=6)$ surface water TDP in FP (33.5 $\mu \mathrm{g} \mathrm{L}-1)$ compared to $\mathrm{F}\left(16.2 \mu \mathrm{g} \mathrm{L}^{-1}\right)$ treatments, this difference was not statistically significant (Table 1). Mean TDP in S treatment plots $\left(43.2 \mu \mathrm{g} \mathrm{L}^{-1}\right)$ was similar to that of

FP treatments (33.5 $\left.\mu \mathrm{g} \mathrm{L}^{-1}\right)$, but was not significantly different than either FP or F $(16.2 \mu \mathrm{g}$ $\left.\mathrm{L}^{-1}\right)$. The SP treatment had the highest mean TDP concentrations $\left(162.9 \mu \mathrm{g} \mathrm{L}^{-1}\right)$ and was significantly different than all 3 other treatments. Soluble reactive P (SRP) in the fresh- 
$\left(1.7 \pm 1.3 \mu \mathrm{g} \mathrm{L}^{-1}\right)$ and saltwater $\left(4.7 \pm 2.7 \mu \mathrm{g} \mathrm{L}^{-1}\right)$ sources $(\mathrm{C}-111$ canal and Florida Bay, respectively) was not significantly different (Wilson et al. in review, Servais et al. in review).

\section{Periphyton functional responses}

The TP, TN, chl- $a$ content of periphyton plugs were generally higher in phosphorus treatments regardless of salt treatment, although these trends were not always statistical significant (Tukey post-hoc test, $\alpha=0.05$ ) (Figure 3). Periphyton TP was significant higher in the FP and SP treatments, which were not significantly different from each other despite higher TDP concentrations in the SP treatment. TP was not significantly different between $\mathrm{F}$ and $\mathrm{S}$ treatments. Although periphyton $\mathrm{TN}$ was higher in the FP compared to $\mathrm{F}$ treatment and in the SP compared to the S treatment, the only significant difference was between FP and S treatments. Periphyton TC content was significantly greater in both fresh compared to salt treatments regardless of the $\mathrm{P}$ treatment. The pairwise comparisons on periphyton chl- $a$ concentrations did not detect significant difference between any of the treatments, but the estimated marginal means plot shows a trend of elevated chl- $a$ in P-treated mats and decreased periphyton chl- $a$ concentrations in S compared to F treatments.

Accumulation rates of periphyton AFDM and chl-a measured from settlement plate samples were not significantly different across treatments (Tukey post-hoc test, $\alpha=0.05$ ) but showed general trends similar to those seen for TC and chl- $a$ content in periphyton plugs (Figure 4). AFDM accumulation rates tended to be lower in salinity compared to freshwater treatments, and were the lowest in SP treatments. Furthermore, a general pattern of decreasing AFDM accumulation rates over time were also observed. A trend towards 
greater biomass-specific chl- $a$ accumulation rates in P-treated periphyton was observed for both freshwater and salt-treated mats.

Metabolism measurements on periphyton plugs collected on Feb 2016 showed a trend of decreased periphyton NEP and GPP in S treatments (1.6 and $3.1 \mathrm{mg} \mathrm{C} \mathrm{g} \mathrm{AFDM}^{-1}$ $\mathrm{hr}^{-1}$, respectively) compared to $\mathrm{F}$ treatments $\left(2.5\right.$ and $7.2 \mathrm{mg} \mathrm{C}$ g $\mathrm{AFDM}^{-1} \mathrm{hr}^{-1}$, respectively), but these differences were not statistically significant (Tukey post-hoc test, $\alpha=0.05$ ) (Figure 5). No significant differences in periphyton NEP were detected between F treatments $\left(2.5 \mathrm{mg} \mathrm{C} \mathrm{g} \mathrm{AFDM}{ }^{-1} \mathrm{hr}^{-1}\right)$ and FP treatments $\left(2.8 \mathrm{mg} \mathrm{Cg} \mathrm{AFDM}^{-1} \mathrm{hr}^{-1}\right)$. Likewise, there was no statistical difference in periphyton GPP between FP treatments (5.7

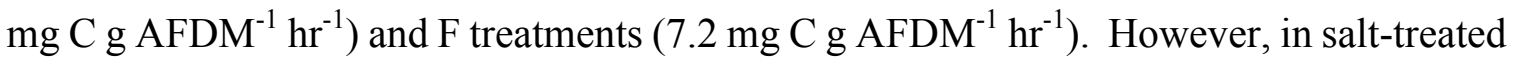
periphyton, the addition of P significantly increased NEP $\left(9.6 \mathrm{mg} \mathrm{C} \mathrm{g} \mathrm{AFDM}{ }^{-1} \mathrm{hr}^{-1}\right)$ and GPP (12.2 mg C g AFDM ${ }^{-1} \mathrm{hr}^{-1}$ ) compared to salt-treated mats with no P additions (1.6 and 3.1 $\mathrm{mg} \mathrm{C} \mathrm{g} \mathrm{AFDM}^{-1} \mathrm{hr}^{-1}$, respectively). Periphyton ER was not affected by any of the treatments, although mean ER was lowest in S treatments.

\section{$\underline{\text { Periphyton diatom assemblages }}$}

The diatom assemblages of periphyton mats subjected to the $\mathrm{F}$ and $\mathrm{S}$ treatments formed two distinct groups in the NMDS ordination; the ANOSIM confirmed these groups were significantly dissimilar (Table 2, Figure 5). Surprisingly, the addition of $\mathrm{P}$ to freshwater periphyton (FP) did not cause significant taxonomic divergence from freshwater control (F) mats. However, both F and FP were significantly different from S and SP. The greatest divergence is taxonomic composition occurred between FP and SP treatments and 
between $\mathrm{F}$ and SP. The addition of $\mathrm{P}$ to salt-treated mats $(\mathrm{SP})$ resulted in a significantly different diatom assemblage than that from $\mathrm{S}$ treatments.

The multi-level pattern analysis identified 13 significant indicators out of a total of 43 taxa (Table 3). Gomphonema parvulum and G. clavatulum were selected as significant indicators of the FP treatment - enriched freshwater conditions; Amphora puctata and Navicula salinicola were identified as significant indicators of the SP treatment - enriched saltwater conditions. The analysis did not detect any species that were solely indicators of F or S treatment conditions. However, we found significant indictors of 3 different treatment combinations that included $\mathrm{F}$ and $\mathrm{S}$ treatments: $\mathrm{F}+\mathrm{FP}, \mathrm{S}+\mathrm{SP}$, and $\mathrm{F}+\mathrm{FP}+\mathrm{S}$. Species associated with the F+FP treatment combination, namely Gomphonema intricatum vibrio and Kobayasiella subtillissima, are freshwater indicators in both enriched and unenriched conditions, at least to the levels P achieved in this experiment. Similarly, indicators of the S+SP treatment combination were saltwater species that performed equally well under the P enrichment level to which they were subjected in this study; these were Amphora coffeaeformis aponina, Fragilaria ftsp 16, and Amphora sulcata. Significant indicators of the treatment group combination $\mathrm{F}+\mathrm{FP}+\mathrm{S}$ included Brachysira microcephela, Achnanthes minutissima, and Diploneis parma. These species performed equally well under enriched and unenriched freshwater conditions and in unenriched saltwater conditions. 


\section{DISCUSSION}

This study is only the second to experimentally evaluate the response of calcareous periphyton mats from karstic, freshwater wetlands to both increased salinity and $\mathrm{P}$ as would be expected with saltwater intrusion (Rejmankova and Kormakova 2005). We successfully elevated mean salinity in S and SP treatments $\sim 7 \mathrm{ppt}$ higher than F and FP treatments with resulting patterns of reduced periphyton TC content and AFDM accumulation rates as well as significant shits in diatom species composition. Surface water TDP was not significantly

elevated in FP compared to $\mathrm{F}$ treatments despite a mean increase of $\sim 17 \mu \mathrm{g} \mathrm{L}^{-1}$. However, periphyton TP was significantly higher in the FP treatments suggesting that even the nonsignificant increase in surface water TDP was reflected in the periphyton mats. Periphyton functional processes and diatom composition were not significantly different between F and FP treatments despite some general trends of increased TN content, chl- $a$ concentration and chl- $a$ accumulation rates, and slightly decreased AFDM accumulation rates, in P-treated freshwater mats. Surface water TDP was successfully elevated in SP compared to $\mathrm{S}$ by almost $4 \mathrm{x}$ and was reflected by a threefold increase in periphyton TP. This was accompanied by significantly higher NEP and GPP in SP compared all other treatments and increased TN content, chl- $a$ concentration and chl- $a$ accumulation rate compared to the S only treatment. This study highlights the importance of understanding how periphyton responds to elevated salinity and $\mathrm{P}$ separately, as well as the response to simultaneous increases in both drivers, to tease apart the effects of different aspects of saltwater intrusion and develop specific diatom indicator taxa that can be used to monitor saltwater intrusion outcomes in the Everglades and other coastal, freshwater wetlands. 
Salinity stress can decrease chlorophyll content, photosynthetic electron transport activities, and the uptake of essential nutrients in non-salt-adapted autotrophs (Lu and Vonshak 2002, Sudhir and Murthy 2004, Hu and Schmidhalter 2005). Mazzei et al. (in prep) reported reduced productivity, total carbon content, and nitrogen and phosphorus uptake in freshwater periphyton mats from the Everglades exposed to experimentally elevated salinity (Mazzei et al. in prep). Here, we found similar effects of elevated salinity on periphyton productivity expressed as lower NEP, GPP, chl- $a$, TC content, and AFDM accumulation rates in salt-treated compared to freshwater mats. Even though we found lower TN in salt-exposed compared to freshwater mats, we did not detect this effect on mat TP. We are uncertain as to why we did not see reduced P uptake in salt-stressed periphyton especially since SRP concentrations in fresh and salt source waters were not significantly different, so we know the S treatment was not getting an unintended $\mathrm{P}$ subsidy.

Declines in periphyton productivity with experimentally elevated salinity have also been reported from karstic wetlands in Belize (Rejmankova and Kormakova 2005), However, the effects of salinity on periphyton ER were not reported in that publication. Based on evidence that elevated salinity increases soil microbial respiration in wetlands (Weston et al. 2011, Chambers et al. 2014, Servais et al. ), periphyton could be expected to respond similarly since these mats host bacterial as well as algal communities. This assumption was not supported by the current study in which we found lower, albeit not significantly, ER rates in S compared to F treatments. Similarly, the only other study to test the effect of elevated salinity on periphyton productivity in the Everglades, found nonsignificant declines in periphyton ER in salt-exposed mats (Mazzei et al. in prep). This suggests that elevated salinity results in metabolic stress that reduces overall productivity 
and respiration in the periphyton micro-ecosystem. Testing the effects of elevated salinity on algal and bacterial components of periphyton separately is an important next step in understanding the mechanisms of overall reduction in periphyton metabolic activity.

Periphyton rapidly assimilates and stores $\mathrm{P}$ through both biotic and abiotic pathways effectively removing excess P from the environment (Scinto and Reddy 2003). Because periphyton mats quickly remove $\mathrm{P}$ from the environment, mat TP is often used as a measure of P loading into Everglades marshes in place of water column measurements (McCormick et al. 2001, Gaiser et al. 2006). As expected, fresh and salt-treated periphyton that received P subsidy (FP and SP) exhibited significantly higher TP content. However, we did not detect significantly greater surface water TDP concentrations in F compared to FP treatments. Whether this was because we did not actually achieve elevated P concentrations in FP compared to F treatments or because the periphyton took it up before we could measure it in the surface water is uncertain. However, the significantly higher mat TP levels in FP compared to F treatments suggests the former. Despite higher mat TP concentrations in FP treatments, we did not detect elevated NEP or GPP in these mats compared to freshwater mats. Biomass-specific chl- $a$ concentrations in periphyton plugs and biomass-specific chl- $a$ accumulation rates were also not significantly different between F and FP treatments, although they tended to be higher in the FP treatment. These results suggest that most of the P taken up by the mats in the FP treatment was through the abiotic pathway of adsorption to $\mathrm{CaCO} 3$ in the mats so that it was not biologically available. On the other hand, addition of P to salt-treated mats significantly increased NEP and GPP compared to mats from any other treatment and chl- $a$ concentrations and accumulation rates also tended to be higher, although not significantly, in SP compared to S treatments. 
Saltwater has been shown to cause $\mathrm{P}$ desorption from $\mathrm{CaCO} 3$ bedrock in the Everglades (Price et al. others papers?), and a similar mechanism may be at play within the calcareous periphyton mats. Unlike the FP treatments, P taken up by mats exposed to SP treatments may have more biologically available $\mathrm{P}$ to support increased algal productivity and potentially mitigate salt stress.

Increased NEP, GPP, and chl-a in SP-treated mats should not be interpreted to mean that native, calcareous periphyton thrive under these conditions. The decline in periphyton TC and AFDM accumulations rates in salt-treated mats suggests a shift in algal composition to salt-tolerant species that are not associated with cohesive, calcareous mats and may indicate a shift towards non-calcareous mats or biofilms with lower biomass and TC content. Surprisingly, we did not see significant reductions in periphyton TC or AFDM accumulation rates with added $\mathrm{P}$, although AFDM accumulation rates tended to be lower with $\mathrm{P}$ exposure, to support findings of calcareous periphyton mat disintegration with $\mathrm{P}$ enrichment. However, TC and AFDM may not be the best metric to capture shifts from cohesive, calcareous mats to unconsolidated periphyton assemblages. Increased dominance of periphyton mats by macroalgal species such as Chara spp. or aquatic plants such as Utricularia spp. that are often associated with freshwater, periphyton mats in the Everglades would exhibit high TC and biomass content although structurally different from typical calcareous microbial mats. It is also possible that the $\mathrm{P}$ loading rates in this experiment were not high enough to illicit a structural response suggesting a threshold for mat TP concentrations to maintain mat integrity. McCormick et al. (1998) report an upper limit of $200 \mu \mathrm{g} \mathrm{g}^{-1}$ of mat TP to maintain mat integrity, but both our FP $\left(516 \mu \mathrm{g} \mathrm{g}^{-1}\right)$ and SP $\left(664 \mu \mathrm{g} \mathrm{g}^{-1}\right)$ exceed this limit without significant decline in mat TC or AFDM 
accumulation rates. Although the exact mechanisms behind calcareous mats breakdown with $\mathrm{P}$ enrichment are uncertain, the loss of calcium-carbonate precipitating cyanobacterial species, Schizothrix and Scytonema, as they are out competed by eutrophic species, and potentially higher bacterial respiration rates within the mats have been cited. Because periphyton absorb and store P quickly, P enrichment may increase bacterial respiration rates within periphyton as the mats become more nutritious (Gasier et al. 2011, Hagerthey et al. 2011). An increase in the oxidation of the periphyton substrate by bacterial assemblages within the mat is one theory explaining the breakdown of mats with $\mathrm{P}$ addition. McCormick et al. (2001) reported that periphyton ER rates tended to increase with P, although this response was not statistically significant. Similarly, we observed increased periphyton ER in SP compared to S treatments but this effect was not significant. Our results suggest that salinity may be a stronger driver of altered periphyton mat structure than $\mathrm{P}$ in the southern Everglades where elevated salinity and $\mathrm{P}$ caused by saltwater intrusion simultaneously influence periphyton structure and taxonomic composition.

Mazzei et al. (in press) found that declines in freshwater periphyton productivity and TC content in response to elevated salinity were accompanied by shifts in periphyticdiatom assemblages to favor salt-tolerant species. Here, we also found that periphytic diatom assemblages were significantly dissimilar between $\mathrm{F}$ and $\mathrm{S}$ treated mats as expected. No significant shifts in diatom composition between F and FP treated mats was detected despite significantly greater mat TP concentrations in FP treatments. This supports our above assumptions that the P inputs to FP mats were possibly adsorbed to $\mathrm{CaCO} 3$ in the mats making them biologically unavailable. It is also possible that we did not elevate P sufficiently in FP treatments to cause mat breakdown documented in other 
studies given that we did not see significant declines in TC or AFDM accumulation rates with added P. This may explain why we did not see significant changes in diatom assemblages in FP compared to F treatments. However, two species of Gomphonema were significantly associated with enriched freshwater conditions suggesting that, even though overall assemblage dissimilarity was not significant, some species did respond to elevated $\mathrm{P}$ conditions and are the best indicators of $\mathrm{P}$ enrichment in freshwater habitats. We identified two other species that were associated with both F and FP treatments, but none that were solely indicators of unenriched freshwater conditions, suggesting that some freshwater species are $\mathrm{P}$ generalists and therefore would not be good indictors of $\mathrm{P}$ enrichment. Likewise, Amphora punctata and Navicula salinicola were significantly associated with SP treatments and can be considered good indicators of P enrichment in saltier environments. On the other hand, Amphora coffeaeformis, A. sulcate, and Fragilaria ftsp16 were associated with both the S and SP treatment; these species make good indicators of elevated salinity but do not provide information about $\mathrm{P}$ conditions. Three species were identified as indicators in F, FP, and $\mathrm{S}$ treatments that can be classified as both salinity and $\mathrm{P}$ generalists.

Our results provide valuable information on the functional and compositional responses of periphyton to individual and effects of increased salinity and $\mathrm{P}$ that can help us predict changes caused by saltwater intrusion, but still leave many questions unanswered due to the complex nature of periphyton mats. Periphyton is essentially a micro-ecosystem with internal biogeochemical cycles and species interactions that are strongly influenced by external ecosystem dynamics. Despite this complexity, diatom assemblages provide us with information regarding both external (i.e., landscape scale changes in abiotic drivers) 
and internal (i.e., periphyton physical structure) environmental conditions. Diatom assemblages not only respond to changes in abiotic drivers, such as salinity and P, but to the structure of the periphyton mats so that the loss of calcareous mats will not support the same diatom assemblages. Although some diatom species contribute to mat formation and cohesion through the production of attachment structure and the excretion of EPS, evidence points to many periphytic diatoms simply relying on calcareous periphyton mats as a microhabitat without necessarily contributing to its cohesion (Mazzei and Gaiser 2016). A better understanding of the direct effects of salinity and $\mathrm{P}$ on diatom composition versus possible indirect effects of calcareous periphyton microhabitat loss or structural changes in response to these drivers is still needed. Furthermore, we need more experimental studies to understand the exact mechanism behind periphyton disintegration with $\mathrm{P}$ enrichment. Future, studies need to focus on a more complete survey of changing autotrophic species composition in response to both salinity and $\mathrm{P}$ to effectively capture the multifaceted responses of periphyton to saltwater intrusion. 


\section{ACKNOWLEDGMENTS}

This research was supported by the National Science Foundation's Florida Coastal Everglades Long Term Ecological Research Program (DEB-1237517). Additional funding was provided through Florida Sea Grant R/C-S-56, including cooperative agreements with the South Florida Water Management District, the Everglades Foundation, and Everglades National Park. We are grateful to the State of Florida Department of Transportation Region 6 Office for working with us to gain permission to access and harvest peat for this experiment. We thank Laura Bauman, Rowan Johnson, Michael Kline, Michelle Robinson, and Ryan Stolee for help in the field; Andres Leon and Sara Osorio for help in sample

processing and data entry; and Franco Tobias for laboratory assistance particularly with species identification. Viviana Mazzei was supported by the Florida International University Dissertation Year Fellowship and the Everglades Foundation ForEverglades Fellowship. This is contribution xxxx of the Southeast Environmental Research Center. 


\section{LITERATURE CITED}

Affenzeller, M.J., Darehshouri, A., Andosch, A., Lütz, C. and Lütz-Meindl, U., 2009. Salt stress-induced cell death in the unicellular green alga Micrasterias denticulata. Journal of experimental botany, 60: 939-954.

Alam, S.M., 1999. Nutrient uptake by plants under stress conditions. Handbook of plant and crop stress, 2, pp.285-313.

Alam, S.M., 1999. Nutrient uptake by plants under stress conditions. Handbook of plant and crop stress, 2, pp.285-313.

Azim, M.E. and Asaeda, T., Periphyton structure, diversity and colonization pp.15-34 In Azim, M.E., Verdegem, M.C., van Dam, A.A. and Beveridge, M.C. eds., 2005. Periphyton: ecology, exploitation and management. CABI.

Briceño, H., Miller, G., Davis III, S. E. 2014. Relating freshwater flow with estuarine water quality in the Southern Everglades mangrove ecotone. Wetlands, 34:101111.

Chambers, L.G., Davis, S.E., Troxler, T., Boyer, J.N., Downey-Wall, A. and Scinto, L.J., 2014. Biogeochemical effects of simulated sea level rise on carbon loss in an Everglades mangrove peat soil. Hydrobiologia, 726(1), pp.195-211.

Childers, D. L., Boyer, J. N., Davis, S. E., Madden, C. J., Rudnick, D. T., Sklar, F. H. 2006. Relating precipitation and water management to nutrient concentrations in the oligotrophic "upside-down" estuaries of the Florida Everglades. Limnology and Oceanography, 51: 602-616.

Clarke K.R. \& Gorley, R.N. (editors). 2006. Primer v6: User Manual/Tutorial. Plymouth: PRIMER-E.

Davis, S. M., Childers, D. L., Lorenz, J. J., Wanless, H. R., Hopkins, T. E. 2005. A conceptual model of ecological interactions in the mangrove estuaries of the Florida Everglades. Wetlands, 25:832-842.

De Cáceres, M., 2013. How to use the indicspecies package. $R$ package version 1.7.1.

De Cáceres, M., Legendre, P. and Moretti, M., 2010. Improving indicator species analysis by combining groups of sites. Oikos, 119(10), pp.1674-1684.

Desrosiers, C., Leflaive, J., Eulin, A. and Ten-Hage, L., 2013. Bioindicators in marine waters: benthic diatoms as a tool to assess water quality from eutrophic to oligotrophic coastal ecosystems. Ecological indicators, 32, pp.25-34. 
Elser, J.J., Bracken, M.E., Cleland, E.E., Gruner, D.S., Harpole, W.S., Hillebrand, H., Ngai, J.T., Seabloom, E.W., Shurin, J.B. and Smith, J.E., 2007. Global analysis of nitrogen and phosphorus limitation of primary producers in freshwater, marine and terrestrial ecosystems. Ecology letters, 10(12), pp.1135-1142.

Gaiser, E. E., McCormick, P. V., Hagerthey, S. E., Gottlieb, A. D. 2011. Landscape patterns of periphyton in the Florida Everglades. Critical Reviews in Environmental Science and Technology, 41: 92-120.

Gaiser, E. E., Trexler, J. C., Jones, R. D., Childers, D. L., Richards, J. H., Scinto, L. J. 2006. Periphyton responses to eutrophication in the Florida Everglades: crosssystem patterns of structural and compositional change. Limnology and Oceanography, 51:617:630

Gaiser, E., 2009. Periphyton as an indicator of restoration in the Florida Everglades. Ecological Indicators, 9(6), pp.S37-S45.

Gaiser, E., Hée, J.M.L., Tobias, F.A. and Wachnicka, A.H., 2010. Mastogloia smithii var lacustris Grun.: a structural engineer of calcareous mats in karstic subtropical wetlands. Proceedings of the Academy of Natural Sciences of Philadelphia, 160, pp.99-112.

Gaiser, E.E., Scinto, L.J., Richards, J.H., Jayachandran, K., Childers, D.L., Trexler, J.C., Jones, R.D., 2004. Phosphorus in periphyton mats provides the best metric for detecting low-level P enrichment in an oligotrophic wetland. Water Research, 38: 507-516.

Hagerthey, S. E., Bellinger, B. J., Wheeler, K., Gantar, M., Gaiser, E. 2011. Everglades periphyton: a biogeochemical perspective. Critical Reviews in Environmental Science and Technology, 41:309-343.

Hasle, G. R., and G. A. Fryxell. 1970. Diatoms: cleaning and mounting for light and electron microscopy. Transactions of the American Microscopical Society 89:469-474.

Herbert, E. R., P. Boon, A. J. Burgin, S. C. Neubauer, R. B. Franklin, M. Ardon, K. N. Hopfensperger, L. P. M. Lamers, and P. Gell. 2015. A global perspective on wetland salinization: ecological consequences of a growing threat to freshwater wetlands. Ecosphere 6.

Hu, Y. and Schmidhalter, U., 2005. Drought and salinity: a comparison of their effects on mineral nutrition of plants. Journal of Plant Nutrition and Soil Science, 168(4), pp.541-549. 
James, K.R., Cant, B. and Ryan, T., 2003. Responses of freshwater biota to rising salinity levels and implications for saline water management: a review. Australian Journal of Botany, 51(6), pp.703-713.

La Hée, J. M., \& E. E. Gaiser. 2012. Benthic diatom assemblages as indicators of water quality in the Everglades and three tropical karstic wetlands. Freshwater Science, $31: 205-221$.

Lu, C. and Vonshak, A., 2002. Effects of salinity stress on photosystem II function in cyanobacterial Spirulina platensis cells. Physiologia plantarum, 114(3), pp.405413.

Mazzei, V. and Gaiser, E., 2017. Scale and spatial consistency of specialization in an endemic and abundant freshwater diatom from the Caribbean Basin. Freshwater Science, 36: 542-554.

Mazzei, V., Gaiser, E.E., Kominoski, J.S., Wilson, B.J., Servais, S., Bauman, L., Davis, S., Kelly, S., Sklar, F., Rudnick, D., Stachelek, J., and Troxler, T. In prep. Functional and compositional responses of periphyton mats to simulated saltwater intrusion in the southern Everglades.

McCormick, P. V. \& O'Dell, M. B. 1996. Quantifying periphyton responses to phosphorus in the Florida Everglades: a synoptic-experimental approach. Journal of the North American Benthological Society, 15:450-468.

McCormick, P.V. and Stevenson, R.J., 1998. Periphyton as a tool for ecological assessment and management in the Florida Everglades. Journal of Phycology, 34(5), pp.726-733.

McCormick, P.V., Harvey, J.W. and Crawford, E.S., 2011. Influence of changing water sources and mineral chemistry on the Everglades ecosystem. Critical reviews in environmental science and technology, 41(S1), pp.28-63.

McCormick, P.V., Harvey, J.W. and Crawford, E.S., 2011. Influence of changing water sources and mineral chemistry on the Everglades ecosystem. Critical reviews in environmental science and technology, 41:28-63.

McCormick, P.V., O’Dell, M.B., Shuford III, R.B., Backus, J.G. and Kennedy, W.C., 2001. Periphyton responses to experimental phosphorus enrichment in a subtropical wetland. Aquatic Botany, 71(2), pp.119-139.

McVoy, C. W., W. P. Said, J. Obeysekera, J. Van Arman, and T. W. Dreschel. 2011. Landscapes and Hydrology of the Predrainage Everglades. University of Florida Press, Gainesville, FL. 
Mendelssohn, I.A., Batzer, D.P., Holt, C.R. and Graham, S.A., 2006. Abiotic constraints for wetland plants and animals. Ecology of freshwater and estuarine wetlands, pp.82-114.

Odum, E.P., Finn, J.T. and Franz, E.H., 1979. Perturbation theory and the subsidy-stress gradient. Bioscience, 29(6), pp.349-352.

Pan, Y., Stevenson, R.J., Vaithiyanathan, P., Slate, J. and Richardson, C.J., 2000. Changes in algal assemblages along observed and experimental phosphorus gradients in a subtropical wetland, USA. Freshwater Biology, 44: 339-353.

Potapova, M. and Charles, D.F., 2007. Diatom metrics for monitoring eutrophication in rivers of the United States. Ecological indicators, 7(1), pp.48-70.

Price, R. M., Swart, P. K., Fourqurean, J. W. 2006. Coastal groundwater discharge-an additional source of phosphorus for the oligotrophic wetlands of the Everglades. Hydrobiologia, 569:23-36.

Rejmánková, E. and Komárková, J., 2000. A function of cyanobacterial mats in phosphorus-limited tropical wetlands. Hydrobiologia, 431(2-3), pp.135-153.

Rejmánková, E. and Komárková, J., 2005. Response of cyanobacterial mats to nutrient and salinity changes. Aquatic Botany, 83(2), pp.87-107.

Ross, M.S., Meeder, J.F., Sah, J.P., Ruiz, P.L., Telesnicki, G.J. 2000. The Southeast Saline Everglades revisited: a half-century of coastal vegetation change. Journal of Vegetation Science, 11:101-112

Saha, A.K., Saha, S., Sadle, J., Jiang, J., Ross, M.S., Price, R.M., Sternberg, L.S., Wendelberger, K.S., 2011. Sea level rise and South Florida coastal forests. Climatic Change, 107: 81-108.

Schedlbauer, J.L., Munyon, J.W., Oberbauer, S.F., Gaiser, E.E. and Starr, G., 2012. Controls on ecosystem carbon dioxide exchange in short-and long-hydroperiod Florida Everglades freshwater marshes. Wetlands, 32(5), pp.801-812.

Scinto, L.J. and Reddy, K.R., 2003. Biotic and abiotic uptake of phosphorus by periphyton in a subtropical freshwater wetland. Aquatic Botany, 77(3), pp.203222.

Stevenson, J., 2014. Ecological assessments with algae: a review and synthesis. Journal of phycology, 50(3), pp.437-461.

Stevenson, R.J., Pan, Y., van Dam, H., 1999. Assessing environmental conditions in rivers and streams with diatoms in The Diatoms: Applications for the Environmental and Earth Sciences, 2nd ed. Cambridge University Press, Cambridge. 
Sudhir, P. and Murthy, S.D.S., 2004. Effects of salt stress on basic processes of photosynthesis. Photosynthetica, 42(2), pp.481-486.

Touchette, B.W., 2007. Seagrass-salinity interactions: physiological mechanisms used by submersed marine angiosperms for a life at sea. Journal of Experimental Marine Biology and Ecology, 350(1-2), pp.194-215.

Trexler, J.C., Gaiser, E.E., Kominoski, J.S. and Sanchez, J., 2015. The role of periphyton mats in consumer community structure and function in calcareous wetlands: lessons from the Everglades. Microbiology of the Everglades Ecosystem. Science Publications, CRC Press, Boca Raton, pp.155-179.

Trobajo, R., Rovira, L., Mann, D.G. and Cox, E.J., 2011. Effects of salinity on growth and on valve morphology of five estuarine diatoms. Phycological Research, 59(2), pp.83-90.

Troxler, T.G., Childers, D.L., Madden, C.J., 2014. Drivers of decadal-scale change in southern Everglades wetland macrophyte communities of the coastal ecotone. Wetlands, 34:81-90.

Vymazal, J. and Richardson, C.J., 1995. Species composition, biomass, and nutrient content of periphyton in the Florida Everglades. Journal of Phycology, 31(3), pp.343-354.

Wanless, H. R. \& Vlaswinkel, B. 2005. Coastal landscape and channel evolution affecting critical habitats at Cape Sable, Everglades National Park, Florida. Final Report to Everglades National Park, United States Department of the Interior, Homestead, FL, USA.

Weston, N.B., Vile, M.A., Neubauer, S.C. and Velinsky, D.J., 2011. Accelerated microbial organic matter mineralization following salt-water intrusion into tidal freshwater marsh soils. Biogeochemistry, 102(1-3), pp.135-151.

Williams, A.A., Lauer, N.T. and Hackney, C.T., 2014. Soil phosphorus dynamics and saltwater intrusion in a Florida estuary. Wetlands, 34(3), pp.535-544. 
Table 4-1. Means and standard deviations of surface water (SW) salinity and total dissolved phosphorus (TDP); chlorophyll- $a$ (Chla), total carbon (TC), total nitrogen (TN), and total phosphorus (TP) content of periphyton plugs; and ash-free dry mass (AFDM) and Chl- $a$ accumulation rates on settlement plates averaged over all sampling dates for each treatment $(\mathrm{F}=$ freshwater, $\mathrm{FP}=$ freshwater and phosphorus, $\mathrm{S}=$ saltwater, $\mathrm{SP}=$ saltwater and phosphorus).

\begin{tabular}{|c|c|c|c|c|c|c|c|c|}
\hline \multirow{2}{*}{$\frac{\text { Measure }}{\text { Abiotic }}$} & \multicolumn{2}{|c|}{$\mathrm{F}$} & \multicolumn{2}{|c|}{ FP } & \multicolumn{2}{|c|}{$\mathrm{S}$} & \multicolumn{2}{|c|}{ SP } \\
\hline & Mean & STDEV & Mean & STDEV & Mean & STDEV & Mean & STDEV \\
\hline SW SAL (ppt) & $0.5^{\mathrm{a}}$ & 0.3 & $0.4^{\mathrm{a}}$ & 0.2 & $7.3^{\mathrm{b}}$ & 4.7 & $7.2^{\mathrm{b}}$ & 4.7 \\
\hline $\mathrm{SW}$ TDP $\left(\mu \mathrm{g} \mathrm{L}^{-1}\right)$ & $16.2^{\mathrm{a}}$ & 14.2 & $33.5^{\mathrm{a}}$ & 22.4 & $43.2^{\mathrm{a}}$ & 105.3 & $162.9^{\mathrm{b}}$ & 321.5 \\
\hline \multicolumn{9}{|l|}{ Periphyton plugs } \\
\hline Chl- $a\left(\mathrm{mg} \mathrm{g} \mathrm{AFDM}^{-1}\right)$ & $2.3^{\mathrm{a}}$ & 4.7 & $3.2^{\mathrm{a}}$ & 2.2 & $1.7^{\mathrm{a}}$ & 1.3 & $3.0^{\mathrm{a}}$ & 2.1 \\
\hline $\mathrm{TC}\left(\mathrm{mg} \mathrm{g}^{-1}\right)$ & $282.6^{\mathrm{a}}$ & 69.1 & $278.6^{\mathrm{a}}$ & 33.0 & $233.9^{\mathrm{b}}$ & 34.9 & $233.3^{\mathrm{b}}$ & 47.0 \\
\hline $\mathrm{TN}\left(\mathrm{mg} \mathrm{g}^{-1}\right)$ & $14.3^{\mathrm{ab}}$ & 6.2 & $17.7^{\mathrm{a}}$ & 5.7 & $12.6^{\mathrm{b}}$ & 3.8 & $15.5^{\mathrm{ab}}$ & 7.6 \\
\hline $\mathrm{TP}\left(\mu \mathrm{g} \mathrm{g}^{-1}\right)$ & $264.6^{\mathrm{a}}$ & 160.9 & $516.2^{b}$ & 208.6 & $206.3^{\mathrm{a}}$ & 111.1 & $664.3^{b}$ & 497.3 \\
\hline \multicolumn{9}{|l|}{ Settlement plates } \\
\hline $\operatorname{AFDM}\left(\mathrm{mg} \mathrm{m}^{-2} \mathrm{~d}^{-1}\right)$ & $88.3^{\mathrm{a}}$ & 84.3 & $86.7^{\mathrm{a}}$ & 81.1 & $70.8^{\mathrm{a}}$ & 71.0 & $58.8^{\mathrm{a}}$ & 47.0 \\
\hline Chl- $a\left(\mu\right.$ g g AFDM $\left.{ }^{-1} \mathrm{~d}^{-1}\right)$ & $114.9^{\mathrm{a}}$ & 60.4 & $161.7^{\mathrm{a}}$ & 73.8 & 120.1 & 81.0 & $134.4^{\mathrm{a}}$ & 87.1 \\
\hline
\end{tabular}


Table 4-2. Analysis of similarity (ANOSIM) pair-wise comparisons among treatments $(\mathrm{F}=$ freshwater, $\mathrm{FP}=$ freshwater and phosphorus, $\mathrm{S}=$ saltwater, $\mathrm{SP}=$ saltwater and phosphorus).

\begin{tabular}{|c|c|c|c|c|c|c|}
\hline \multirow[t]{2}{*}{ Treatment } & \multicolumn{2}{|c|}{$\mathrm{F}$} & \multicolumn{2}{|c|}{$\mathrm{FP}$} & \multicolumn{2}{|c|}{$\mathrm{S}$} \\
\hline & $R$ statistic & $P$-value & $R$ statistic & $P$-value & $R$ statistic & $P$-value \\
\hline FP & 0.013 & 0.392 & & & & \\
\hline $\mathrm{S}$ & 0.376 & $0.009 *$ & 0.619 & $0.002 *$ & & \\
\hline SP & 0.887 & $0.002 *$ & 0.915 & $0.002 *$ & 0.594 & $0.002 *$ \\
\hline
\end{tabular}


Table 4-3. Multi-level pattern analysis (multipatt\{indicspecies\}) results listing diatom taxa significantly associated with treatments and treatment combinations ( $\mathrm{F}=$ freshwater, $\mathrm{FP}=$ freshwater and phosphorus, $\mathrm{S}=$ saltwater, $\mathrm{SP}=$ saltwater and phosphorus).

\begin{tabular}{|c|c|c|c|}
\hline Treatment Group & Taxon & IndVal & p-value \\
\hline \multirow[t]{2}{*}{ FP } & Gomphonema parvulum & 0.896 & 0.010 \\
\hline & Gomphonema clavatulum & 0.816 & 0.001 \\
\hline \multirow[t]{2}{*}{ SP } & Amphora punctata & 0.891 & 0.005 \\
\hline & Navicula salinicola & 0.883 & 0.010 \\
\hline \multirow[t]{2}{*}{$\mathrm{F}+\mathrm{FP}$} & Gomphonema iintricatum vibrio & 0.966 & 0.005 \\
\hline & Kobayasiella subtilissima & 0.800 & 0.015 \\
\hline \multirow[t]{3}{*}{$\mathrm{S}+\mathrm{SP}$} & Amphora coffeaeformis aponina & 0.999 & 0.005 \\
\hline & Fragilaria ftsp 16 & 0.957 & 0.005 \\
\hline & Amphora sulcata & 0.866 & 0.010 \\
\hline \multirow[t]{3}{*}{$\mathrm{F}+\mathrm{FP}+\mathrm{S}$} & Brachysira microcephela & 0.976 & 0.005 \\
\hline & Achnanthes minutissima & 0.927 & 0.010 \\
\hline & Diploneis parma & 0.902 & 0.050 \\
\hline
\end{tabular}


Figure 4-1. Layout of the 6 concrete crypts and the housing containers for the 4 sawgrass cores (A) and a close-up of one of the individual housing containers with the sawgrass core and periphyton. Conceptual diagram of the experimental design (C). Rectangles represent individual crypts (white rectangle $=$ fresh crypts; gray rectangle $=$ salinity crypts). Circles represent cores and the letters designate the treatment each core received $(\mathrm{F}=$ freshwater control; $\mathrm{FP}=$ freshwater and phosphorus; $\mathrm{S}=$ salinity; $\mathrm{SP}=$ salinity and phosphorus.

A.

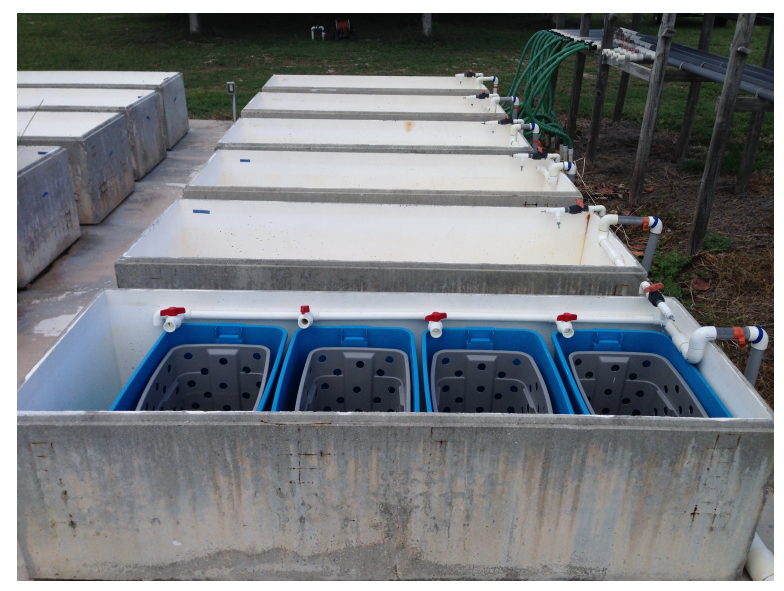

C.

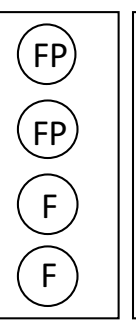

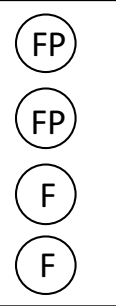

B.

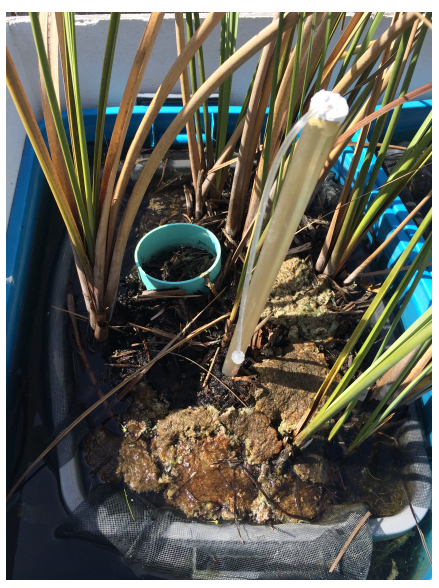


Figure 4-2. Monthly mean surface water (SW) salinity (A) and total dissolved phosphorus (TDP) (B) across treatments $(n=6)$.
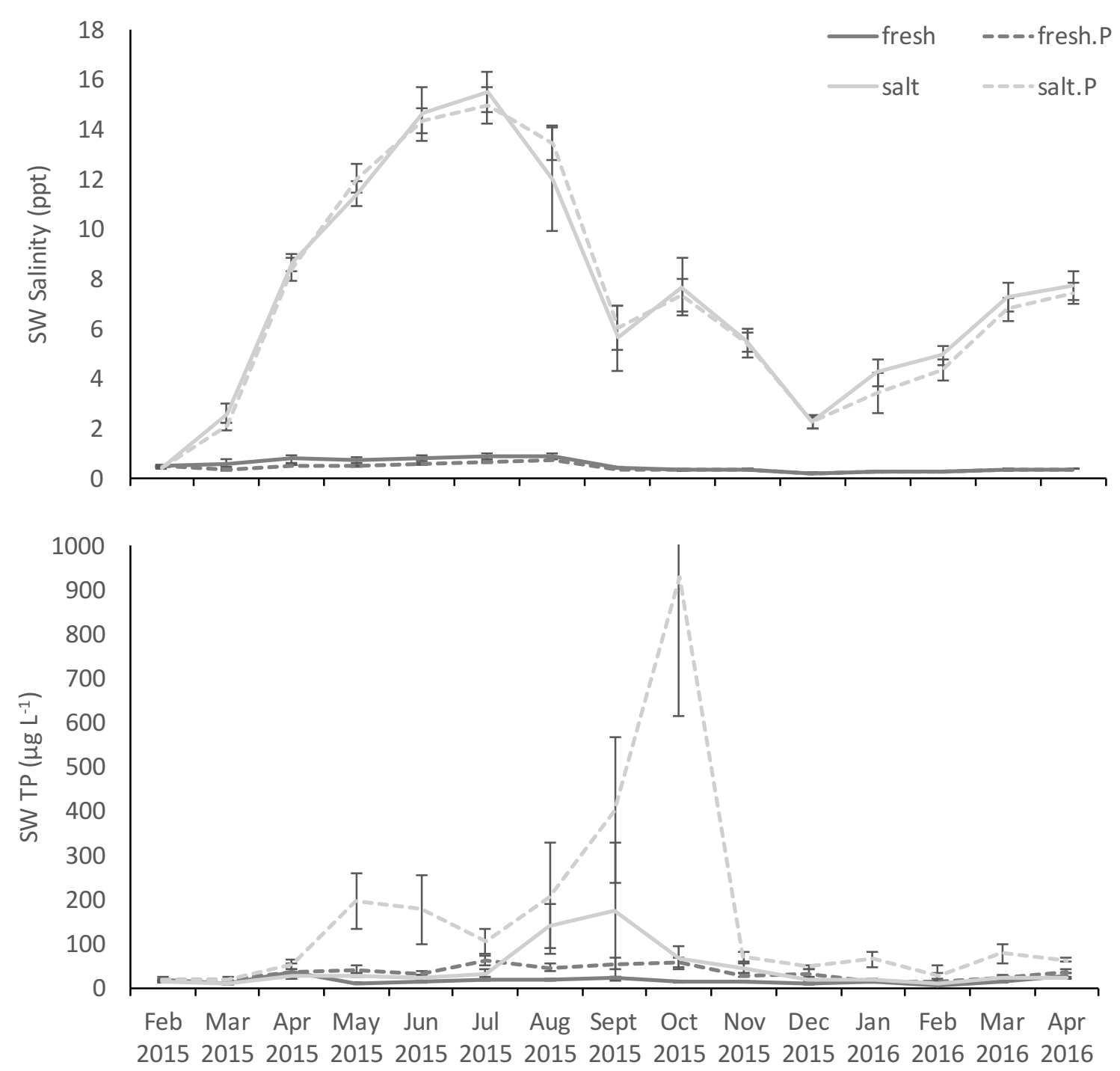
Figure 4-3. Bi-monthly mean periphyton total phosphorus (TP), total nitrogen (TN), total carbon (TC), and chlorophyll- a (Chl- $a$ ) (column A) across treatments $(n=6)$. Multivariate analysis of variance (MANOVA) estimated marginal means for each variable across treatments (column B).
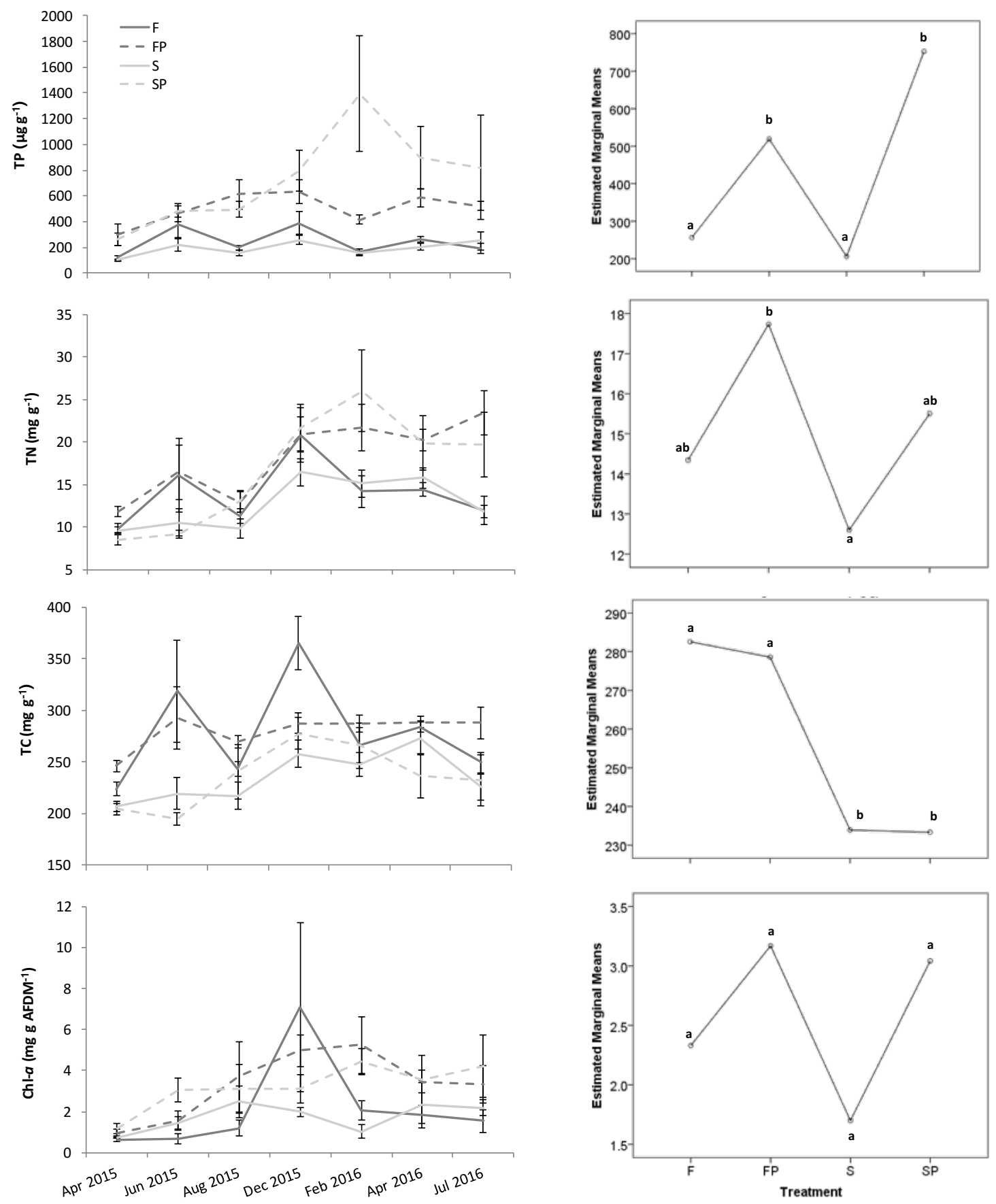
Figure 4-4. Mean periphyton ash-free dry mass (AFDM) and biomass-specific chlorophyll$a(\mathrm{Chl}-a)$ accumulation rates across treatment for each settlement plate deployment period (column A). Multivariate analysis of variance (MANOVA) estimated marginal means for each variable across treatments (column B).
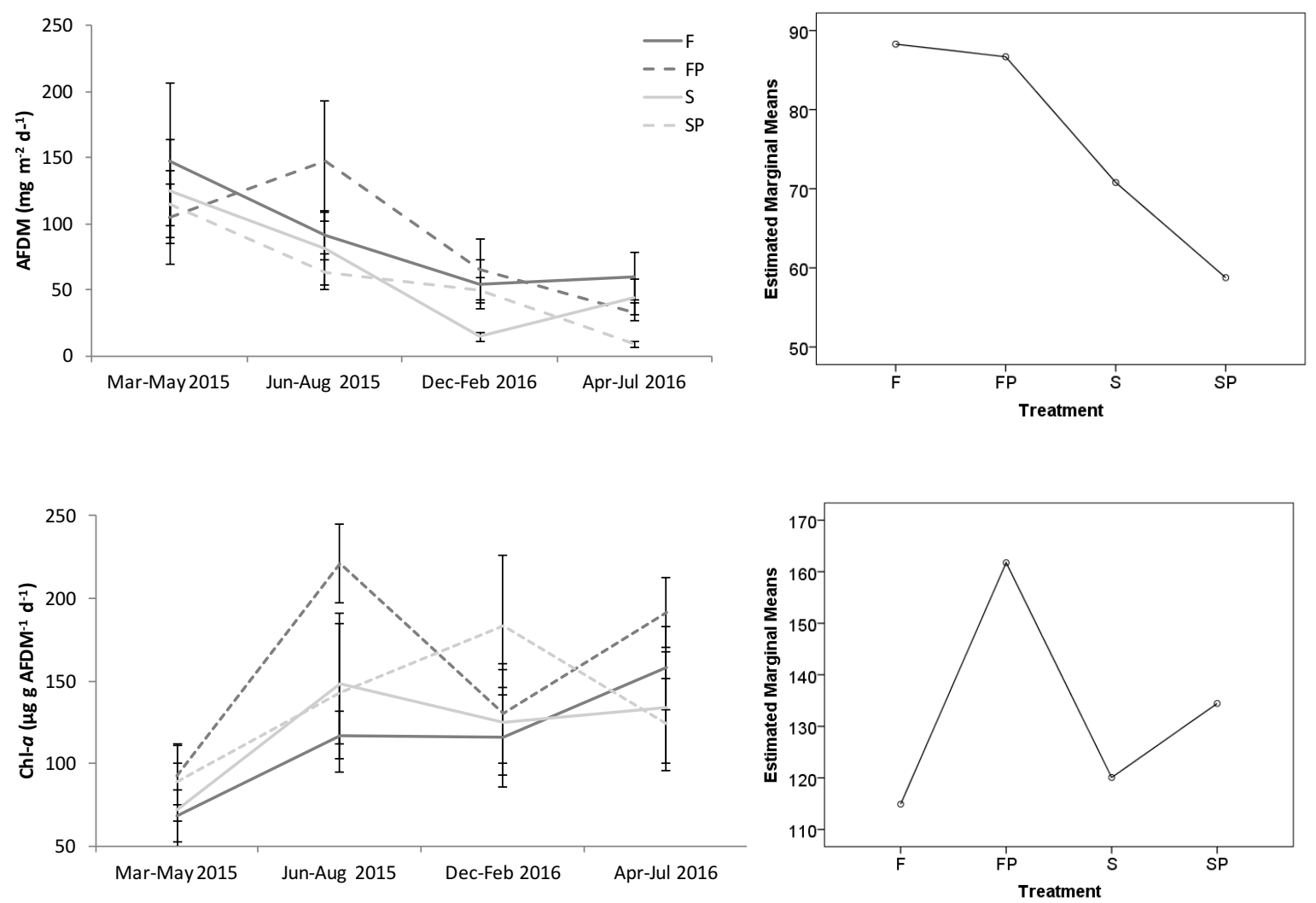
Figure 4-5. Periphyton net ecosystem productivity (NEP), ecosystem respiration (ER), and gross primary productivity (GPP) one time measurements on periphyton plugs collected on February 2016. Lettering indicates significant differences among treatments for each variable based on MANOVA post hoc pair-wise comparisons across treatment groups.

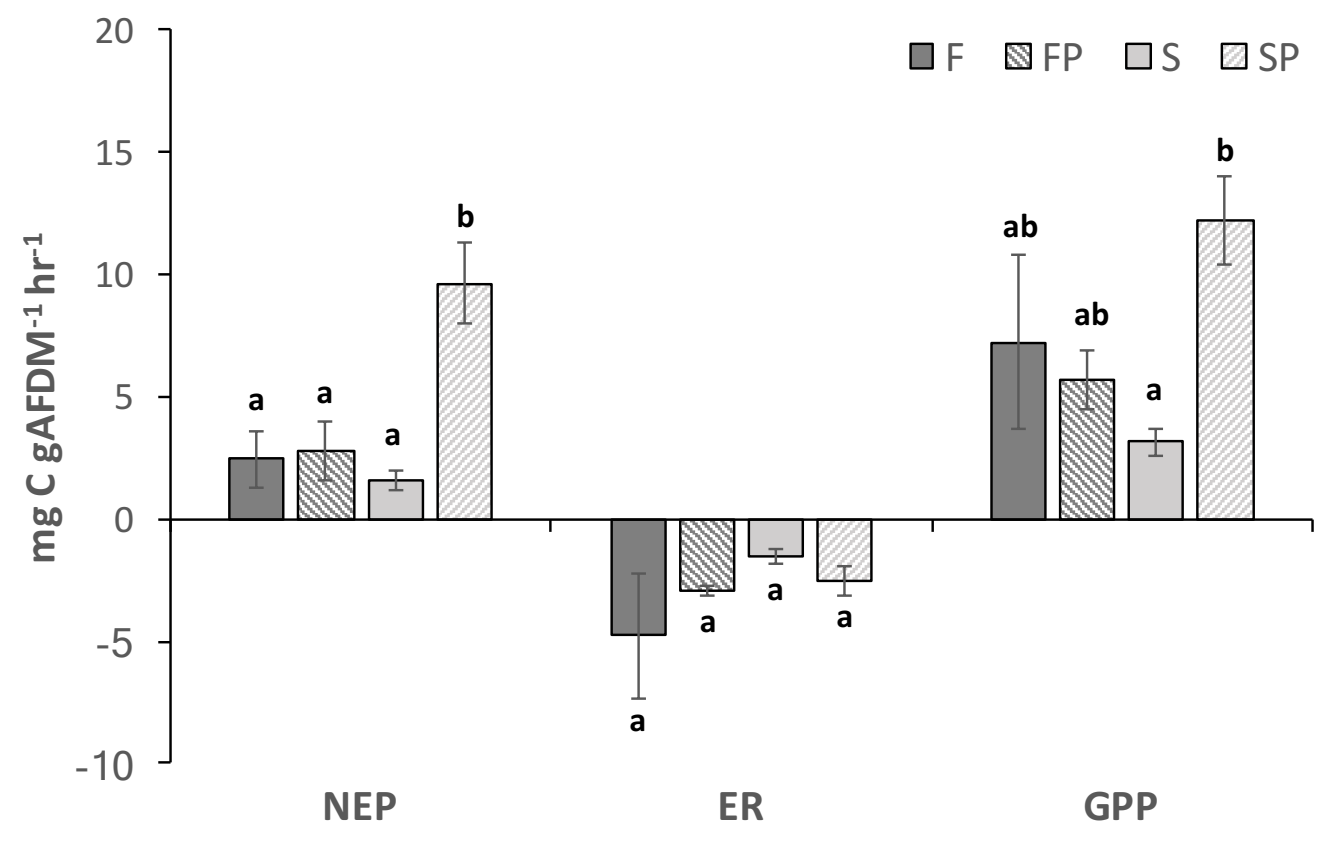


Figure 4-6. NMDS ordination of diatom species dissimilarity among treatments $(\mathrm{F}=$ freshwater, $\mathrm{FP}=$ freshwater and phosphorus, $\mathrm{S}=$ saltwater, $\mathrm{SP}=$ saltwater and phosphorus).

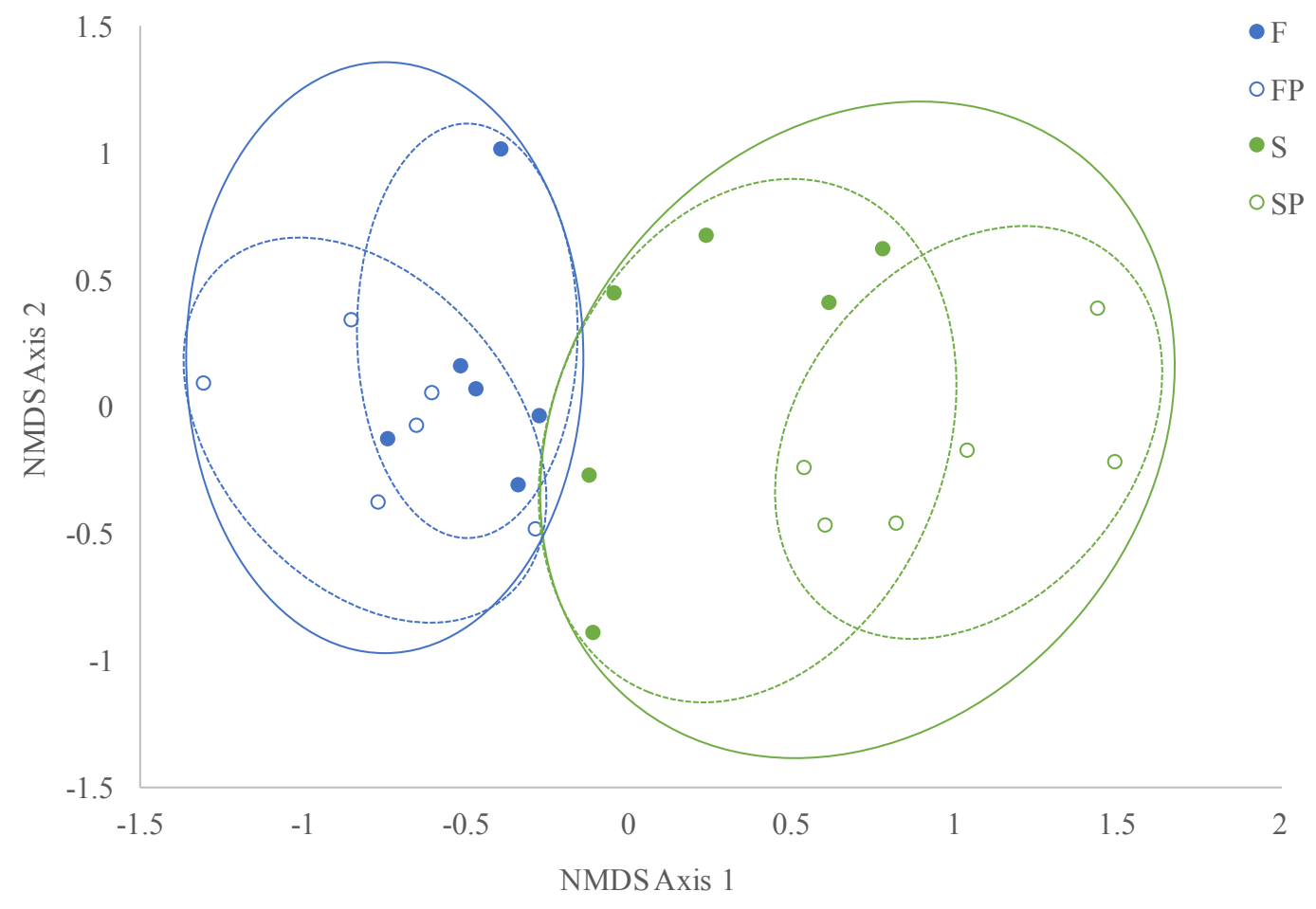




\title{
CHAPTER V
}

\section{SCALE AND SPATIAL CONSISTENCY OF SPECIALIZATION IN AN ENDEMIC} AND ABUNDANT FRESHWATER DIATOM FROM THE CARIBBEAN BASIN

\begin{abstract}
We used populations of an abundant diatom in calcareous microbial mats, Encyonema evergladianum, from 3 karstic wetlands in the Caribbean Basin to test whether the relative abundance of this species is more strongly driven by macrohabitat features (landscape-scale gradients of conductivity and $\mathrm{P}$ availability) or mat microhabitat characteristics (biomass and mineral content), and whether specialization is maintained in populations from geographically separated but environmentally similar wetlands. We found that, across Caribbean wetlands, the abundance of E. evergladianum was most strongly tied to microbial-mat biomass, suggesting that this species is specialized for, and probably contributes to, the unique conditions of these mats. However, the magnitude and importance of micro- and macroscale drivers on E. evergladianum abundance differed among wetlands, which implies that this diatom has differentiated ecotypically across its range. We found no morphological correlates to potential ecotypes, making it difficult to distinguish between ecotypes without molecular studies. We also searched for an engineering role of E. evergladianum in mat structure by examining freeze-fractured mat fragments under scanning electron microscopy, but found no morphological evidence for functional contributions to mat cohesion. Encyonema evergladianum is a consistently
\end{abstract}


strong indicator of oligotrophic, freshwater conditions that promote calcareous microbial mats in coastal karstic wetlands of the Caribbean. Variability in the scales of specialization by microbial species requires calibration of quantitative, abundance-based approaches to habitat assessment in the context of individual wetlands, particularly in these wetlands where ecosystem-scale changes are abrupt in response to climate and anthropogenic changes in nutrient delivery and salinity.

\section{INTRODUCTION}

The distribution and abundance of species are controlled by environmental, spatial, and historical factors, the relative importance of which varies according to the shape of environmental gradients, taxon life-history strategies, and the spatiotemporal scales of metapopulation dynamics (Chase and Myers 2011, Weiher et al. 2011). For habitat specialists, abundance patterns are thought to be under stronger control by environmental rather than dispersal-related or historical processes because their narrow environmental tolerances restrict them to certain habitat features or conditions (Kolsa and Romanuk 2005, Pandit et al. 2009, DeVictor et al. 2010). Relative abundance provides a measure of species performance and can be used to define specialization when abundance is greatest within a narrow range of environmental and biological conditions (Futuyma and Moreno 1988). Specialization also can be defined by the species' role in or effect on its environment (i.e.,

functional specialization), as with ecosystem engineers (DeVictor et al. 2010). The confinement of specialist species to certain environmental conditions or habitats makes them potentially powerful indicators of changes in environmental conditions and habitat 
availability, including those caused by anthropogenic pressures, such as climate change and eutrophication (Soininen 2007). However, a clear understanding of the drivers of specialization and the scale at which they operate is critical to using specialists as indicators of environmental change. Furthermore, extrapolation of indicators developed in one location to other similar environments is often desirable but requires knowledge about the maintenance of specialization across space.

Key environmental factors influencing the abundance and distribution of species can occur at different scales and may have cascading effects on one another making it difficult to determine which factors exert the strongest control on species performance and, thus, define its specialization. For example, in the Florida Everglades and similar karstic wetlands throughout the Caribbean Basin, P availability and conductivity are landscape scale (macroenvironmental) drivers of the quantity (i.e., biomass), quality (i.e., mineral content), and species composition of the characteristic calcareous microbial mats found throughout these systems. However, these 2 macroenvironmental drivers interact with characteristics of the mat itself (microhabitat drivers) that regulate and are regulated by mat-dwelling organisms and their interactions. The integrity of calcareous mats and their unique species composition depend on preservation of the natural environmental conditions found in karstic wetlands, particularly low conductivity and P (Rejmánková and Komárková 2005, Gaiser et al. 2006, 2011, Slate and Stevenson 2007, Hagerthey et al. 2011). These landscapes are naturally P-limited systems with low conductivity that exhibit a gradient of increasing $\mathrm{P}$ and conductivity from interior freshwater marshes to the coast. However, saltwater intrusion coupled with water-management practices are altering this natural gradient with important consequences for the ecological communities found there 
(Childers et al. 2006, Price et al. 2006, La Hée 2010, Saha et al. 2011, La Hée and Gaiser 2012). Calcareous microbial mats are especially sensitive to elevated P concentrations, which trigger biogeochemical processes within the mats that cause them to break down and eventually to be replaced by noncalcitic filamentous mats or biofilms with different algal communities (Gaiser et al. 2006, 2011, Hagerthey et al. 2011). Calcareous microbial mats are usually absent in areas closer to the coast where conductivity is higher, but their absence from these areas has not been directly linked to conductivity and may be a result of the relatively higher $\mathrm{P}$ concentrations that occur there than in interior marshes (Childers et al. 2006). Elevated P and conductivity are associated with decreased abundance of calcareous microbial mats and replacement by noncalcitic mats, but the effect of these macroenvironmental drivers on species composition, particularly of the diatom community, can be confounded by their effect on the structure of the mat microhabitat in which these species live (i.e., microhabitat-scale drivers).

Shifts in microbial mat community composition, particularly the diatom assemblages, have been associated with changes in $\mathrm{P}$ and conductivity, but the degree to which the relative abundance of these diatoms reflects their preferences and tolerances for these macroenvironmental drivers or the cascading effects of these drivers on mat structure and function remains uncertain. $\mathrm{P}$ enrichment can initiate compositional changes associated with mat breakdown including the loss of calcium-carbonate precipitating cyanobacterial species (i.e., Schizothrix and Scytonema) that form the backbone of calcareous mats and diatoms that contribute to mat cohesion (i.e., Mastogolia calcarea (syn. M. smithii); Gaiser et al. 2006, 2011, Hagerthey et al. 2011). Elevated conductivity also creates unfavorable conditions for calcareous mat formation, as evidenced by their 
absence from coastal marshes, because changes in ion concentrations alter mat chemistry and trigger bacterial and algal community composition shifts to species that form organic mats and biofilms. However, these effects have not been tested experimentally. Calcareous microbial mats contain several endemic diatom species, some of which play important roles in mat formation and cohesion (Slate and Stevenson 2007, Gaiser et al. 2010). The distribution and abundance patterns of these endemic species suggest specialization for the chemical and biological conditions found in these microhabitats indicating that at least some of these species respond to the loss of calcareous mat habitat, driven by the replacement of ecosystem-engineer species that play a functional role in mat formation rather than by elevated $\mathrm{P}$ and conductivity directly. To understand specialization properly in these diatom communities and in general, we must address whether these apparent niche restrictions are caused directly by tolerances for factors acting at the macroenvironmental scale or indirectly through the effects of those drivers on the immediate microhabitat experienced by these microorganisms.

The consistency of the drivers across geographically separated but environmentally similar habitats also must be addressed to extend species-based metrics of environmental change developed in one location to other ecologically similar ecosystems. Extrapolation of habitat preferences of a specialist in one location to other suitable habitats depends on how and whether preferences are preserved across the regional population. Their environmental specificity implies that specialist species respond to environmental gradients consistently across their geographic range, but the environmental or biological circumstances under which specialization originated may have differed in some areas of the species' range causing the population to diverge into subpopulations with differing 
levels of specialization (Futuyma and Moreno 1988, van Tienderen 1991, Bolnick et al. 2003). This process, called ecotypic differentiation, occurs through the evolution of genotypes or when existing genetic variability within a population is differentially expressed as environments change over time and can result in nonconformity of ecological preferences or morphologies among subpopulations (Sultan and Spencer 2002, Poisot et al. 2011). Nonconformity could be a problem if species-based ecological predictions developed for one ecosystem are applied elsewhere because subpopulations from different locations cannot be expected to respond in the same ways to changing environmental conditions. For example, diatom communities are used commonly as ecological indicators of nutrient enrichment and elevated conductivity in the Everglades where natural water quality is being altered by saltwater intrusion caused by sea-level rise and watermanagement practices (Frankovich et al. 2006, Wachnicka et al. 2011, La Hée and Gaiser 2012, Bramburger et al. 2013, Lee et al. 2014. However, similar metrics have not been well established in other karstic wetlands in the Caribbean Basin. Understanding whether diatom indicators respond to the same drivers across karstic wetlands in the Caribbean Basin or if specialization is context-dependent would allow us to extend Everglades-based metrics to encompass the entire region. Such knowledge also would contribute to an understanding of ecotypic differentiation in microorganisms that are easily dispersed, such as diatoms. Because the Caribbean Basin regional diatom species pool probably is not limited by dispersal given the relatively short distances among karstic wetlands in the region ( $<1500 \mathrm{~km}$; van der Gucht et al. 2007, Potapova and Charles 2002, Bennett et al. 2010), differences in specialization among populations from individual wetlands can be assumed to reflect environmental differences rather than dispersal barriers. Furthermore, 
the possibility for ecotypic differentiation without morphological correlates must be appreciated in studies of ecological indicator species that are based solely on morphological traits, such as diatoms whose identification is based largely on frustular ornamentation.

We used populations of an abundant and endemic mat-dwelling diatom, Encyonema evergladianum, from subtropical and tropical karstic wetlands to test 3 hypotheses. 1) Microhabitat-scale features (i.e., mat ash-free dry mass [AFDM] and mat mineral content) are stronger determinants of the relative abundance of mat-dwelling diatom species than macroenvironmental drivers (i.e., landscape conductivity and $\mathrm{P}$ gradients). We propose that specialization at the micro scale is a result of the integration of macroscale environmental (abiotic) gradients with microhabitat conditions mediated by biological interactions. 2) Microhabitat specialization has been maintained across karstic wetland landscapes in the Caribbean Basin because the presumed environmental similarity and capacity for dispersal among karstic wetlands should prevent divergent selection into separate ecotypes. If this hypothesis is false, we expect that long-term ecological differences among karstic wetlands in the Caribbean Basin have caused populations to diverge into distinct ecotypes that can be differentiated based on morphology. We tested this hypothesis by comparing morphometric data of E. evergladianum from each wetland to assess whether populations exhibit distinct morphologies based on location. 3) Matdwelling diatoms whose abundance is most strongly related to microhabitat quantity and quality can be expected to play a role in the creation and maintenance of the mat microhabitat structure given that dominant species often influence their surroundings. We investigated the engineering role of E. evergladianum in calcareous microbial mats by 
examining scanning electron micrographs (SEMs) of freeze-fractured mat fragments, which capture the ultra-ecology and morphology of this diatom.

\section{METHODS}

Encyonema evergladianum was first described by Krammer (1997) from samples collected in the Florida Everglades (but see Mazzei 2014). It has been described as endemic to tropical and subtropical karstic wetlands with a particularly high affinity for the calcareous microbial-mat microhabitats found in these ecosystems (Slate and Stevenson 2007, La Hée and Gaiser 2012). It is reduced in abundance when calcareous mats disappear in the presence of high conductivity and $\mathrm{P}$ and, therefore, has been identified as a valuable indicator of oligotrophic, freshwater conditions (Slate and Stevenson 2007, Gaiser et al. 2006, Wachnicka et al. 2010). These characteristics make it an ideal organism with which to address the ecological questions we pose. The results of this research will help establish the strength of this species as a regional bioindicator for freshwater karstic wetlands in the Caribbean Basin that are threatened in similar ways by saltwater intrusion, freshwater diversion, and nutrient enrichment (Gaiser et al. 2015).

Scale and maintenance of drivers of specialization across wetlands

We investigated specialization for drivers operating at different scales by examining the response of E. evergladianum relative abundance to 2 macroenvironmental drivers, conductivity and mat total P (TP) concentration, and 2 micro-scale drivers, mat AFDM and mineral content, in 3 karstic wetlands of the Caribbean Basin: the Everglades 
(Florida, USA), Sian Ka'an Biosphere Reserve (Yucatan, Mexico), and the New River Lagoon (Belize). We used mat TP to estimate TP in the environment and, therefore, we consider mat TP a macroenvironmental driver in our paper. Mat TP can be a more sensitive gauge of $\mathrm{P}$ loading than concentrations in the water column because $\mathrm{P}$ inputs are taken up rapidly by microbial mats and other vegetation, and it is virtually undetectable in the water column (Gaiser et al. 2004). Mat areal AFDM represents the amount of organic biomass per unit area available for occupation by diatoms and other organisms, and we used it as a measure of habitat availability. We used $\%$ mat mineral (i.e., inorganic) content as a proxy for mat calcareousness because mats with higher mineral content also have high calcium carbonate concentrations. Samples were collected during the wettest time of year along freshwater-to-coastal gradients of increasing P availability and conductivity from 12 sites in the Everglades (2013), Yucatan (2006), and Belize (2007) for a total of 36 sites (see summary in La Hée and Gaiser 2012).

At each site, we measured conductivity $(\mu \mathrm{S} / \mathrm{cm})$ with a YSI 30 Pro meter (Yellow Springs Incorporated, Yellow Springs, Ohio) and harvested microbial mats from a 1- $\mathrm{m}^{2}$ quadrat. We placed the harvested material in a perforated graduated cylinder to drain excess water and measured total mat biovolume $\left(\mathrm{mL} / \mathrm{m}^{2}\right)$. We placed a $120-\mathrm{mL}$ subsample of the total harvested material in a plastic sample bag, transported it back to the laboratory on ice, and stored it in a $-20^{\circ} \mathrm{C}$ freezer until processed. We thawed samples and transferred them to clean Tupperware dishes where plant material, rocks, or other fragments were removed using forceps. We homogenized the cleaned periphyton in a $500-\mathrm{mL}$ beaker with a hand-held blender. The volume of the homogenized sample was recorded to account for dilution with deionized (DI) water used to facilitate cleaning and homogenizing the sample. 
We placed the beaker on a stir plate and subsampled for TP content, biomass, and $E$. evergladianum relative abundance.

We placed the biomass subsample in a drying oven at $80^{\circ} \mathrm{C}$ for $\geq 48 \mathrm{~h}$ to obtain a dry mass (DM; g) measurement and then in a furnace where it was combusted at $500^{\circ} \mathrm{C}$ for $1 \mathrm{~h}$ to obtain an ash (mineral) mass $(\mathrm{g})$. We calculated AFDM, organic biomass, by the loss-on-ignition method as the difference between the ash mass and the total DM and standardized to area $\left(\mathrm{g} / \mathrm{m}^{2}\right)$ by scaling the subsample biomass to the total area sampled and correcting for dilution with DI water during the cleaning process. We calculated mat mineral content as the $\%$ ash mass of the total DM. We dried the TP subsamples at $80^{\circ} \mathrm{C}$ and pulverized them with a mortar and pestle. We processed a known amount of each subsample based on colorimetric analysis to estimate TP concentration, expressed as $\mu \mathrm{g} / \mathrm{g}$ mat DM, following the methods of Solorzano and Sharp (1980).

We cleaned the diatom subsamples of mineral debris and organic matter with the sulfuric acid oxidation methods published by Hasle and Fryxell (1970). We pipetted a known volume of cleaned diatom samples onto a glass coverslips, permanently mounted them on microscope slides with Naphrax (PhycoTech Inc., St. Joseph, Michigan) mounting medium, and viewed them under a compound light microscope. We identified $E$. evergladianum valves among $\geq 500$ diatom valves counted along random transects at $600 \times$ magnification under oil immersion.

We organized the data into 4 groups for statistical analysis: Everglades, Belize, Yucatan, and the 3 locations combined, and used 1-way analysis of variance (ANOVA) test for differences in E. evergladianum abundance, TP, conductivity, periphyton AFDM, and mineral content among the 3 locations. When significant differences were present, we 
used Tukey's post hoc test to identify which locations differed. We created Pearson correlation matrices for the Everglades, Belize, and Yucatan data sets to explore the independent relationships among all 4 variables in each wetland. We then used multiple linear regressions for each of the 4 data sets to assess which variable(s) best explained $E$. evergladianum abundance at the local scale of individual wetlands and at the regional scale of the Caribbean Basin (combined data set). Conductivity, TP, and AFDM were $\log (x)$ transformed to improve linearity and 2 extreme conductivity outliers were removed from the Yucatan data set. Statistical analyses were performed in R (version 3.1.2; R Project for Statitical Computing, Vienna, Austria) and SPSS (version 23; IBM, Armonk, New York).

\section{Morphological ecotypes}

We compared morphometric data from each of the 3 locations to assess whether populations of E. evergladianum from different locations express distinct morphologies that reflect possible ecological difference among them. We measured taxonomically diagnostic morphological features, including length, width, L:W ratio, striae density, and dorsal valve curvature, for 35 individuals from each location, and we attempted to capture the widest range of valve sizes. We calculated curvature with the methods given by Bixby and Zeek (2010). All morphometric measurements were made from digital images taken under a light microscope (Axioskop 2; Zeiss, Thornwood, New York) equipped with differential interference contrast and a digital camera (DFC425; Leica, Wetzlar, Germany).

Digital images were analyzed and prepared for publication using GIMP 2.8.10 (The GIMP team; www.gimp.org). Nonmetric multidimensional scaling (NMDS) and analysis of similarity (ANOSIM) were performed using PRIMER 6 (PRIMER-E, Albany Auckland, 
New Zealand) to assess whether individuals of E. evergladianum form significantly different groups corresponding to the Everglades, Belize, and Yucatan locations based on frustular morphology. Vectors were fitted onto the ordination to visualize which morphological features are driving any observed clustering.

\section{$\underline{\text { Functional specialization within the microhabitat }}$}

We investigated potential functional specialization in E. evergladianum by examining SEMs of freeze-fractured mat fragments to search for physical evidence that this diatom contributes to microhabitat formation, such as mucilage secreting pores, mucilaginous sheaths, stalks, or other structures that might contribute to mat cohesion. We fixed calcareous microbial mats collected from the 12 Everglades sites in $2 \%$ glutaraldehyde and stored them in 20-mL scintillation vials until processed. Mat samples from the Belize and Yucatan site were unavailable for SEM analysis. We prepared the mats for SEM by first decanting the glutaraldehyde and washing the samples with DI water before freezing the samples in liquid $\mathrm{N}$ and fracturing them with a hammer and chisel. We transferred the fragments back to the scintillation vials where they were dehydrated in a series of increasing concentrations $(40,60,80$, and $100 \%)$ of ethyl alcohol. We further dehydrated the samples by critical-point drying in a Tousimis samdri-PVT-3D critical point dryer (Tousimis ${ }^{\circledR}$, Rockville, Maryland) to preserve the 3-dimensional structure of the mats. We mounted the dehydrated samples on stubs and coated them with Au for observation with the SEM (JEOL JSM 5900LV, Florida Center for Analytical Electron Microscopy, Florida International University, Mini, Florida). In addition, we observed live specimens of E. evergladianum from wet mounts of diatom samples from each of the 3 
wetlands to search for evidence of functional specialization that may have been destroyed during the preparation of samples for SEM analysis. For example, nonmotile species of Encyonema often grow in colonies within mucilaginous tubes that potentially contribute to mat structure and cohesion. However, the growth form of E. evergladianum is not known and is important in understanding the role of this species in microbial mat engineering.

\section{RESULTS}

$\underline{\text { Scale and maintenance of drivers of specialization across wetlands }}$

Mean E. evergladianum abundance did not differ among the 3 karstic wetlands (Fig. 1A). Conductivity was significantly higher in the Yucatan than the other 2 wetlands, but all 3 locations had similar values of mat TP (Fig. 1B, C). Periphyton from the Everglades did not have significantly higher mineral content than either other location, but AFDM was significantly greater in the Everglades than in the Yucatan and Belize (Fig. 1D, E).

Pearson correlations revealed that the Everglades, Belize, and Yucatan wetlands have different environments with unique interactions among drivers (Table 1). Mat mineral content was negatively correlated with mat TP at all 3 locations and with conductivity only in the Everglades. Conductivity and mat TP were positively correlated in the Everglades and negatively correlated in the Yucatan. The correlations among E. evergladianum abundance and environmental drivers were not consistent across the 3 locations (Table 1). Encyonema evergladianum abundance was negatively correlated with mat TP and positive correlated with mat mineral content (mat calcareousness) and AFDM in the Everglades 
and Belize but not in the Yucatan. Encyonema evergladianum abundance and conductivity were negatively correlated in the Everglades and the Yucatan.

The multiple linear regression analyses indicated that E. evergladianum abundance responded more strongly to microhabitat availability (periphyton AFDM) than to macroenvironmental factors at the regional scale, but this response was not always consistent at the local scale of individual wetlands (Table 2). AFDM was the strongest driver of abundance in Belize and the Everglades, but not in the Yucatan where conductivity, followed by TP, had the strongest influence on relative abundance (Fig. 2AD).

\section{Morphological ecotypes}

The ANOSIM and post hoc test on E. evergladianum frustular morphology provided evidence for the existence of morphological ecotypes among the 3 populations. The ANOSIM was significant $(R=0.174, p=0.001)$ and pairwise comparisons showed that specimens from the Everglades, Belize, and Yucatan were all significantly different from one another $(p<0.05)$. However, based on the regression analyses, we expected only the Yucatan population to express significantly different morphology from the other 2 wetlands. The unexpected significant morphological differences between the Everglades and Belize populations do not appear to have an ecological basis given that the regression analysis did not reveal ecotypic differentiation in these populations. The NMDS plot shows considerable overlap among wetlands, the separation of Everglades specimens from Belize and Yucatan specimens is clear and is supported by the results of the ANOSIM, which established that the Everglades population is more dissimilar from the Belize and Yucatan 
populations than these 2 are from each other (Fig. 3). The morphological vectors fitted onto the ordination demonstrate specimens from the Everglades having longer and wider valves than those from Belize and Yucatan (Fig. 4A-C, Table 3).

Functional specialization within the microhabitat

Encyonema evergladianum in calcareous microbial mats (Fig. 5A) was embedded in the extracellular polymeric substance (EPS) matrix that cements the mats into cohesive assemblages (Fig. 5B). Contrary to our expectation, we did not observe attachment structures or structures producing extracellular mucilage that could contribute to mat cohesion, or any evidence of calcium carbonate formation along its margins (Fig. 5C, D). Wet mounts of the diatom samples provided observations of live E. evergladianum specimens when viewed under the light microscope. In these wet mounts, we did not observe colonies of E. evergladianum growing in tubes. Instead, this species was highly motile, which may explain the lack of attachment structures.

\section{DISCUSSION}

Our results suggest that the relative abundance of the regional E. evergladianum population is most strongly driven by microscale features of the local habitat, particularly calcareous microbial-mat biomass, an important ecosystem component of karstic, freshwater wetlands. However, subpopulations from the 3 wetlands, particularly the Yucatan, did not respond consistently to the environmental drivers considered in our study. 
This result suggests that divergent selection may have led to the evolution of ecotypes within the Caribbean Basin. Morphological differences among the 3 subpopulations did not reflect the ecological difference observed in the Yucatan subpopulation. Furthermore, we did not observe any structures that would confer an engineering role in calcareous periphyton mat construction or maintenance in E. evergladianum and, therefore, we found no evidence of functional specialization. The occurrence of ecotypic differentiation in diatom species, despite their lack of significant dispersal barriers on intermediate spatial scales and the absence of morphological correlates to help identify ecotypes has important implications for the use of diatoms in ecosystem assessments to infer or predict environmental conditions on both regional and local scales.

Encyonema evergladianum is considered an indicator species of low $\mathrm{P}$ and conductivity in the Everglades (Gaiser et al. 2006, Wachnicka et al. 2010, Frankovich and Wachnicka 2015) and other karstic wetlands of the Caribbean (La Hée and Gaiser 2012). However, we hypothesized that the decline in E. evergladianum abundance along gradients of increasing $\mathrm{P}$ and conductivity results from the replacement of calcareous microbial mats by noncalcareous mats at the high end of these gradients, rather than to these environmental variables directly. Consistent with other studies, we found that high concentrations of mat TP are associated with decreased mat biomass at all 3 locations (Gaiser et al. 2006, La Hée and Gaiser 2012). However, calcareous mat biomass was negatively affected by elevated conductivity only in the Everglades. This finding probably is a consequence of elevated P in coastal waters of the Everglades (Childers et al. 2006) rather than of conductivity directly, especially considering that conductivity did not have a negative effect on mat biomass in the Yucatan or Belize, where conductivity and TP were not correlated. As 
expected, the low abundance of mat microhabitat when $\mathrm{P}$ was elevated had a stronger influence on the relative abundance of the regional E. evergladianum population than its presumed requirements for low conductivity and $\mathrm{P}$. This finding is supported by results of other studies in which microhabitat specialization was demonstrated in microorganisms. For example, Besemer et al. (2012) studied community assembly in stream biofilm microhabitats and found that biofilm community structure was not a stochastic product of random colonization by microbes from the overlying water into the biofilm. Instead, the biofilm acted as a fine-scale environmental filter that selected for a specific biofilm community.

Despite the apparent response of the regional E. evergladianum population to microhabitat availability, the 3 populations did not respond to the same drivers at the local scale. Unlike the Everglades and Belize populations, where microbial mat AFDM was the strongest predictor of abundance, the Yucatan population responded most strongly to conductivity and mat TP. Furthermore, inconsistent interactions between predictor variables within individual wetlands indicated that their environments differ to some degree, despite reports of environmental and floristic similarity among karstic wetlands in the Caribbean (Estrada-Loera 1991, La Hée 2010, Gaiser et al. 2010). Therefore, at the local scale, specialization appears to be context dependent, such that historical or extant environmental conditions at each location may have caused ecotypic differentiation in this diatom.

Ecotypes evolve because of environmental heterogeneity or dispersal limitation (Whittaker 2006, Lee and Olds 2011). However, dispersal barriers are unlikely to exist for diatoms at the distance between karstic wetlands in the Caribbean Basin. Evidence for 
dispersal limitation of microorganisms has been mounting (Vanormelingen et al. 2008, Whittaker et al. 2003), but dispersal limitation is highly scale-dependent and most investigators have found that it plays an important role only at large spatial scales (van der Gucht et al. 2007, Potapova and Charles 2002). For example, Bennett et al. (2010) found that dispersal limitation is important for diatoms only at the intercontinental scale, whereas at the regional scale $\left(<1,000,000 \mathrm{~km}^{2}\right)$ a single environmental factor explained $5 \times$ more of the community variation than space. The maximum distance between wetlands in our study was $<1500 \mathrm{~km}$, supporting the idea that environmental heterogeneity, and not restricted gene flow caused by dispersal limitation, has facilitated divergent selection and ecotypic differentiation of E. evergladianum in the Caribbean Basin.

Ecological differences among ecotypes may be correlated with morphological characteristics that can be used to distinguish between ecotypes. Morphological difference is particularly important in studies where species identification is based largely on morphology, as is often the case in diatom research. We were unable to detect morphological correlates associated with the response of E. evergladianum to ecological drivers in our study. The significant morphological differences among specimens from the 3 wetlands were not consistent with the patterns of ecological differentiation detected by the regression analysis. Molecular tests could help to identify an underlying genetic component that is not morphologically expressed and that might explain the ecological differences observed for the Yucatan population. Such data could indicate whether the ecological differences are a result of ecotypic differentiation rather than sampling biases or other confounding factors. Molecular studies also would allow us to test the possibility that E. evergladianum contains cryptic diversity, i.e., genetically distinct species that are 
morphologically indistinguishable. Several diatoms previously considered one species based on morphological characteristics alone have been found to possess ecologically differentiated cryptic species, including Navicula phyllepta (Vanelslander et al. 2009), Sellaphora pupula (Poulíčková et al. 2008), and Skeletonema costatum (Balzano et al. 2010). Therefore, investigators of ecotypic differentiation in specialist diatom species should use a combination of ecological, morphological, and genetic tests to assess whether divergent selection for locally favored genotypes has led to the divergence of specialization across space and whether these differences are expressed morphologically.

Observation of microbial mat fragments and E. evergladianum ultrastructural features under SEM did not reveal an engineering role in mat structure for this diatom. This result suggests a lack of functional specialization and was surprising because this diatom is found in high relative abundance in calcareous mats and could be expected to have some effect on its immediate environment. Gaiser et al. (2010) found that Mastogloia calcarea, another dominant mat-dwelling diatom from the Caribbean Basin, contributes to mat structure via production of mucilaginous strands issued from marginal pores along the valve mantle. Encyonema evergladianum does not possess any mucilage-secreting pores or mucilaginous sheaths that might contribute to mat formation and cohesion. However, its high relative abundance within calcareous mats suggests that some other microhabitat characteristic not measured here is responsible for E. evergladianum's affinity to calcareous periphyton or that it plays an important functional role in these mats that has yet to be determined. For instance, calcareous microbial mats may provide protection from grazing and desiccation or may concentrate certain ions, such as $\mathrm{Ca}^{2+}$ and $\mathrm{HCO}_{3}{ }^{-}$favored by E. evergladianum. Calcium carbonate in the mats undergoes dissolution resulting in the 
production of soluble calcium bicarbonate at night when $\mathrm{pH}$ becomes elevated in the absence of photosynthesis (Merz 1992, Hagerthey 2011). Ca is an important nutrient in diatom growth, particularly for the cymbelloid group to which E. evergladianum belongs, and can enhance the adhesion of diatoms to polysaccharides, an abundant component of periphyton mats (Patrick 1977, Geesey et al. 2000, Potapova and Charles 2003). Cymbelloid diatoms also have high optima for $\mathrm{HCO}_{3}{ }^{-}$(the other ion produced through the dissolution of calcium carbonate), which is used as the inorganic $\mathrm{C}$ source for photosynthesis and may indicate that these diatoms are able to precipitate calcium carbonate, thereby contributing to mat structure (Tortell et al. 1997, Potapova and Charles 2003).

In conclusion, our study supports the idea that specialization is not a stable ecological trait (Barnagaud et al. 2011) and that the degree of specialization is scale and context dependent. Despite local specialization differences, E. evergladianum is associated with pristine conditions found in karstic wetlands and, thus, represents a potentially powerful tool to track and predict environmental modifications caused by climate irregularities and anthropogenic pressures that threaten these unique wetlands. However, the application of this species as an indicator at the regional scale may result in overlooking or misinterpreting local change unless responses are calibrated based on conditions within individual wetlands. Genetic studies of E. evergladianum from karstic wetlands throughout the Caribbean are necessary to be certain of ecotypic differentiation within this species. In addition, the exact driver of E. evergladianum dominance within the calcareous periphyton diatom community requires further elucidation to define its niche adequately and to use it confidently as an ecological indicator in karstic wetlands. 


\section{ACKNOWLEDGEMENTS}

We thank Franco Tobias for field and laboratory assistance; Josette La Hée for providing the Caribbean data sets; John Kominoski, Luca Marazzi, Jennifer Richards, Associate Editor Steven Francoeur, and 2 anonymous referees for reviewing and providing comments that significantly improved the quality of this manuscript; Mark Edlund and Sarah Spaulding for their help with the species treatment conducted during the Ecology and Systematics of Diatoms course at Iowa Lakeside Laboratory. This work was supported in part by the National Science Foundation through the Florida Coastal Everglades LongTerm Ecological Research program under Cooperative Agreements DEB-1237517, DBI0620409, and DEB-9910514, and by the Everglades Foundation. This is contribution number 824 from the Southeast Environmental Research Center in the Institute of Water and Environment at Florida International University. 


\section{LITERATURE CITED}

Balzano, S., D. Sarno, and W. H. Kooistra. 2010. Effects of salinity on the growth rate and morphology of ten Skeletonema strains. Journal of Plankton Research 33:937-945.

Barnagaud, J. Y., V. Devictor, F. Jiguet, and F. Archaux. 2011. When species become generalists: on-going large-scale changes in bird habitat specialization. Global Ecology and Biogeography 20:630-640.

Bennett, J. R., B. F. Cumming, B. K. Ginn, and J. P. Smol. 2010. Broad-scale environmental response and niche conservatism in lacustrine diatom communities. Global Ecology and Biogeography 19:724-732.

Besemer, K., H. Peter, J. B. Logue, S. Langenheder, E. S. Lindström, L. J. Tranvik, and T. J. Battin. 2012. Unraveling assembly of stream biofilm communities. ISME Journal 6:1459-1468.

Bixby, R. J., and E. C. Zeek. 2010. A simple method for calculating valve curvature. Proceedings of the Academy of Natural Sciences of Philadelphia 160:73-81.

Bolnick, D. I., R. Svanbäck, J. A. Fordyce, L. H. Yang, J. M. Davis, C. D. Hulsey, and M. L. Forister. 2003. The ecology of individuals: incidence and implications of individual specialization. American Naturalist 161:1-28.

Bramburger, A. J., J. W. Munyon, and E. E. Gaiser. 2013. Water quality and wet season diatom assemblage characteristics from the Tamiami Trail pilot swales sites (Everglades National Park, Florida, USA). Phytotaxa 127:163-182.

Chase, J. M., and J. A. Myers. 2011. Disentangling the importance of ecological niches from stochastic processes across scales. Philosophical Transactions of the Royal Society of London Series B: Biological Sciences 366:2351-2363.

Childers, D. L., J. N. Boyer, S. E. Davis, C. J. Madden, D. T. Rudnick, and F. H. Sklar. 2006. Relating precipitation and water management to nutrient concentrations in the oligotrophic "upside-down" estuaries of the Florida Everglades. Limnology and Oceanography 51:602-616.

DeVictor, V., J. Clavel, R. Julliard, S. Lavergne, D. Mouillot, W. Thuiller, P. Venail, S. Villeger, and N. Mouquet. 2010. Defining and measuring ecological specialization. Journal of Applied Ecology 47:15-25.

Estrada-Loera, E. 1991. Phytogeographic relationships of the Yucatan Peninsula. Journal of Biogeography 18:687-697. 
Frankovich, T.A., E. E. Gaiser, J. C. Zieman, and A. H. Wachnicka. 2006. Spatial and temporal distributions of epiphytic diatoms growing on Thalassia testudinum Banks ex König: relationships to water quality. Hydrobiologia 569:259-271.

Frankovich, T. A., and A. Wachnicka. 2015. Epiphytic diatoms along phosphorus and salinity gradients in Florida Bay (Florida, USA), an illustrated guide and annotated checklist. Pages 241-288 in J. A. Entry, A. D. Gottlieb, K. Jayachandran, and A. Ogram (editors). Microbiology of the Everglades ecosystem. CRC Press, Boca Raton, Florida.

Futuyma, D. J., and G. Moreno. 1988. The evolution of ecological specialization. Annual Review of Ecology and Systematics 19:207-233.

Gaiser, E. E., E. P., Anderson, E. Castañeda-Moya, L. Collado-Vides, J. W. Fourqurean, M. R. Heithaus, R. Jaffé, D. Lagomasino, N. J. Oehm, R. M. Price, and V. H. Rivera-Monroy. 2015. New perspectives on an iconic landscape from comparative international long-term ecological research. Ecosphere 6:1-18.

Gaiser, E., J. M. La Hée, F. A. C. Tobias, A. H. Wachnicka. 2010. Mastogloia smithii var. lacustris Grun.: a structural engineer of calcareous periphyton mats in karstic subtropical wetlands. Proceedings of the Academy of Natural Sciences of Philadelphia 160:99-112.

Gaiser, E. E., P. V. McCormick, S. E. Hagerthey, and A. D. Gottlieb. 2011. Landscape patterns of periphyton in the Florida Everglades. Critical Reviews in Environmental Science and Technology 41:92-120.

Gaiser, E. E., L. J. Scinto, J. H. Richards, K. Jayachandran, D. L. Childers, J. C. Trexler, and R. D. Jones. 2004. Phosphorus in periphyton mats provides the best metric for detecting low-level P enrichment in an oligotrophic wetland. Water Research 38:507-516.

Gaiser, E. E., J. C. Trexler, R. D. Jones, D. L. Childers, J. H. Richards, and L. J. Scinto. 2006. Periphyton responses to eutrophication in the Florida Everglades: crosssystem patterns of structural and compositional change. Limnology and Oceanography 51:617-630.

Geesey, G. G., B. Wigglesworth-Cooksey, and K. E. Cooksey. 2000. Influence of calcium and other cations on surface adhesion of bacteria and diatoms: a review. Biofouling 15:195-205.

Hagerthey, S. E., B. J. Bellinger, K. Wheeler, M. Gantar, E. Gaiser. 2011. Everglades periphyton: a biogeochemical perspective. Critical Reviews in Environmental Science and Technology 41:309-342.

Hasle, G. R., and G. A. Fryxell. 1970. Diatoms: cleaning and mounting for light and 
electron microscopy. Transactions of the American Microscopical Society 89:469-474.

Kolasa, J., and T. N. Romanuk. 2005. Assembly of unequals in the unequal world of a rock pool metacommunity. Pages 212-232 in M. Holyoak, M. A. Leibold, and R. D. Holt (editors). Metacommunities: spatial dynamics and ecological communities. University of Chicago Press, Chicago, Illinois.

Krammer, K. 1997. Die cymbelloiden Diatomeen. Eine Monographie der weltweit bekannten Taxa. Teil 2. Encyonema part., Encyonopsis and Cymbellopsis. Bibliotheca Diatomologica 37:1-469.

La Hée, J. M. 2010. The influence of phosphorus on periphyton mats from the Everglades and three tropical karstic wetlands. Florida Institute of Technology Electronic Theses and Dissertations. Paper 251. Florida Institute of Technology, Miami, Florida.

La Hée, J. M., and E. E. Gaiser. 2012. Benthic diatom assemblages as indicators of water quality in the Everglades and three tropical karstic wetlands. Freshwater Science 31:205-221.

Lee, S. S., E. E. Gaiser, and J. C Trexler. 2013. Diatom-based models for inferring hydrology and periphyton abundance in a subtropical karstic wetland: Implications for ecosystem-scale bioassessment. Wetlands 33:157-173.

Lee, C. R., and T. M. Olds. 2011. Quantifying effects of environmental and geographical factors on patterns of genetic differentiation. Molecular Ecology 20:4631-4642.

Mazzei, V. 2014. Encyonema evergladianum in Diatoms of the United States. US Geological Survey/Institute of Arctic and Alpine Research, University of Colorado, Boulder, Colorado. (Available from: http://westerndiatoms.colorado.edu/taxa/species/encyonema_evergladianum)

Merz, M. U. 1992. The biology of carbonate precipitation by cyanobacteria. Facies 26:81-101.

Pandit, S. N., J. Kolasa, and K. Cottenie. 2009. Contrasts between habitat generalists and specialists: an empirical extension to the basic metacommunity framework. Ecology 90:2253-2262.

Patrick, R. 1977. Ecology of freshwater diatoms and diatom communities. Biology of Diatoms 13:284-332.

Poisot, T., J. D. Bever, A. Nemri, P. H. Thrall, and M. E. Hochberg. 2011. A conceptual framework for the evolution of ecological specialisation. Ecology Letters 14:841851. 
Potapova, M. and D. Charles. 2002. Benthic diatoms in USA rivers: distributions along spatial and environmental gradients. Journal of Biogeography 29:167-187.

Potapova, M., and D. F. Charles. 2003. Distribution of benthic diatoms in US rivers in relation to conductivity and ionic composition. Freshwater Biology 48:13111328 .

Poulíčková, A., J. Špačková, M. G. Kelly, M. Duchoslav, and D. G. Mann. 2008. Ecological variation within Sellaphora species complexes (Bacillariophyceae): specialists or generalists? Hydrobiologia 614:373-386.

Price, R. M., P. K. Swart, and J. W. Fourqurean. 2006. Coastal groundwater discharge-an additional source of phosphorus for the oligotrophic wetlands of the Everglades. Hydrobiologia 569:23-36.

Rejmánková, E., and J. Komárková. 2005. Response of cyanobacterial mats to nutrient and salinity changes. Aquatic Botany 83:87-107.

Saha, A. K., S. Saha, J. Sadle, J. Jiang, M. S. Ross, R. M. Price, L. S. Sternberg, and K. S. Wendelberger. 2011. Sea level rise and South Florida coastal forests. Climatic Change 107:81-108.

Slate, J. E., and R. J. Stevenson. 2007. The diatom flora of phosphorus enriched and unenriched sites in an Everglades marsh. Diatom Research 22:355-386.

Soininen, J. 2007. Environmental and spatial control of freshwater diatoms - a review. Diatom Research 22:473-490.

Solórzano, L., and J. H. Sharp. 1980. Determination of total dissolved phosphorus and particulate phosphorus in natural waters. Limnology and Oceanography 25. doi: 10.4319/1o.1980.25.4.0754

Sultan, S. E. and H. G. Spencer. 2002. Metapopulation structure favors plasticity over local adaptation. American Naturalist 160:271-283.

Tortell, P. D., J. R. Reinfelder, and F. M. Morel. 1997. Active uptake of bicarbonate by diatoms. Nature 390:243-244.

van der Gucht, K., K. Cottenie, K. Muylaert, N. Vloemans, S. Cousin, S. Declerck, E. Jeppesen, J. M. Conde-Porcuna, K. Schwenk, G. Zwart, and H. Degans. 2007. The power of species sorting: local factors drive bacterial community composition over a wide range of spatial scales. Proceedings of the National Academy of Sciences of the United States of America 104:20404-20409.

Vanelslander, B., V. Creach, P. Vanormelingen, A. Ernst, V. A. Chepurnov, E. Sahan, G. Muyzer, L. J. Stal, W. Vyverman, and K. Sabbe. 2009. Ecological differentiation between sympatric pseudocryptic species in the estuarine benthic diatom Navicula 
phyllepta (Bacillariophyceae). Journal of Phycology 45:1278-1289.

Vanormelingen, P., E. Verleyen, and W. Vyverman. 2008. The diversity and distribution of diatoms: from cosmopolitanism to narrow endemism. Biodiversity and Conservation 17:393-405.

van Tienderen, P. H. 1991. Evolution of generalists and specialist in spatially heterogeneous environments. Evolution 45:1317-1331.

Wachnicka, A., E. Gaiser, L. Collins, T. Frankovich, and J. Boyer. 2010. Distribution of diatoms and development of diatom-based models for inferring salinity and nutrient concentrations in Florida Bay and adjacent coastal wetlands of south Florida (USA). Estuaries and Coasts 33:1080-1098.

Weiher, E., D. Freund, T. Bunton, A. Stefanski, T. Lee, and S. Bentivenga. 2011. Advances, challenges and a developing synthesis of ecological community assembly theory. Philosophical Transactions of the Royal Society of London Series B: Biological Sciences 366:2403-2413.

Whitaker, R. J. 2006. Allopatric origins of microbial species. Philosophical Transactions of the Royal Society of London Series B: Biological Sciences 361:1975-1984.

Whitaker, R. J., D. W. Grogan, and J. W. Taylor. 2003. Geographic barriers isolate endemic populations of hyperthermophilic archaea. Science 301:976 
Table 5-1. Correlations between Encyonema evergladianum \% relative abundance, total P (TP), ash-free dry mass (AFDM), \% mineral content, and conductivity for each region given by Pearson correlation coefficients. ${ }^{*}=p<0.05$.

\begin{tabular}{|c|c|c|c|c|c|c|c|c|c|c|c|c|}
\hline \multirow[b]{3}{*}{ Variable } & \multicolumn{4}{|c|}{ Everglades } & \multicolumn{4}{|c|}{ Belize } & \multicolumn{4}{|c|}{ Yucatan } \\
\hline & \multicolumn{4}{|c|}{ Mineral Abundance $\log (\mathrm{TP}) \log (\mathrm{AFDM})$} & \multicolumn{4}{|c|}{ Mineral Abundance $\log (\mathrm{TP}) \log (\mathrm{AFDM})$} & \multicolumn{4}{|c|}{ Mineral Abundance $\log (\mathrm{TP}) \log (\mathrm{AFDM})$} \\
\hline & $(\%)$ & $(\%)$ & $(\mu \mathrm{g} / \mathrm{g})$ & $\left(\mathrm{g} / \mathrm{m}^{2}\right)$ & $(\%)$ & $(\%)$ & $(\mu \mathrm{g} / \mathrm{g})$ & $\left(\mathrm{g} / \mathrm{m}^{2}\right)$ & $(\%)$ & $(\%)$ & $(\mu \mathrm{g} / \mathrm{g})$ & $\left(\mathrm{g} / \mathrm{m}^{2}\right)$ \\
\hline Abundance (\%) & $0.71^{*}$ & & & & $0.88^{*}$ & & & & 0.10 & & & \\
\hline $\log (\mathrm{TP})(\mu \mathrm{g} / \mathrm{g})$ & $-0.68^{*}$ & $-0.76^{*}$ & & & $-0.8^{*}$ & $-0.82 *$ & & & $-0.61^{*}$ & 0.00 & & \\
\hline $\log (\mathrm{AFDM})\left(\mathrm{g} / \mathrm{m}^{2}\right)$ & $0.66^{*}$ & $0.85^{*}$ & $-0.85^{*}$ & & $0.87^{*}$ & $0.96^{*}$ & $-0.86^{*}$ & & $0.83^{*}$ & 0.04 & $-0.69^{*}$ & \\
\hline \multicolumn{13}{|l|}{$\log$ (conductivity) } \\
\hline$(\mu \mathrm{S} / \mathrm{cm})$ & $-0.56^{*}$ & $-0.62 *$ & $0.86^{*}$ & $-0.86^{*}$ & 0.57 & 0.48 & -0.05 & 0.35 & 0.51 & $-0.71^{*}$ & $-0.73 *$ & 0.12 \\
\hline
\end{tabular}


Table 5-2. Results of the multiple linear regressions on Encyonema evergladianum percent relative abundance against total $\mathrm{P}$ (TP), conductivity (cond), ash-free dry mass (AFDM), and \% mineral content for the combined data set and each individual wetland. $*=p<0.1, * *=p<0.05$.

\begin{tabular}{|c|c|c|c|c|c|c|c|c|c|}
\hline \multirow[b]{3}{*}{ Region } & \multirow[b]{3}{*}{ Adjusted $R^{2}$} & \multirow[b]{3}{*}{$F$} & \multirow[b]{3}{*}{$p$} & \multirow[b]{3}{*}{ Predictors } & \multirow{3}{*}{\multicolumn{3}{|c|}{$\begin{array}{c}\text { Standardized } \\
\text { coefficient } \\
\beta\end{array}$}} & \multirow[b]{3}{*}{$t$} & \multirow[b]{3}{*}{$p$} \\
\hline & & & & & & & & & \\
\hline & & & & & & & & & \\
\hline \multirow[t]{5}{*}{ Combined } & 0.582 & 11.78 & 0.000 & (Constant) & 46.715 & 35.867 & & 1.302 & 0.204 \\
\hline & & & & $\log (\mathrm{TP})$ & -9.164 & 13.332 & -0.128 & -0.687 & 0.498 \\
\hline & & & & $\log ($ Cond $)$ & -12.41 & 8.95 & -0.186 & -1.387 & 0.177 \\
\hline & & & & $\log (\mathrm{AFDM})^{*}$ & 11.361 & 5.779 & 0.406 & 1.966 & 0.060 \\
\hline & & & & Mineral & 0.352 & 0.21 & 0.335 & 1.677 & 0.105 \\
\hline \multirow[t]{5}{*}{ Everglades } & 0.725 & 8.264 & 0.009 & (Constant) & -133.501 & 91.187 & & -1.464 & 0.187 \\
\hline & & & & $\log (\mathrm{TP})$ & -17.458 & 20.177 & -0.320 & -0.865 & 0.416 \\
\hline & & & & $\log ($ Cond $)$ & 53.056 & 33.524 & 0.579 & 1.583 & 0.158 \\
\hline & & & & $\log (\mathrm{AFDM})^{* *}$ & 29.707 & 11.255 & 0.950 & 2.639 & 0.033 \\
\hline & & & & Mineral & 0.171 & 0.199 & 0.193 & 0.855 & 0.421 \\
\hline \multirow[t]{2}{*}{ Belize } & 0.925 & 34.698 & 0.000 & (Constant) & -6.145 & 52.119 & & -0.118 & 0.909 \\
\hline & & & & $\log (\mathrm{TP})$ & -40.780 & 32.106 & -0.366 & -1.270 & 0.245 \\
\hline
\end{tabular}




\begin{tabular}{|c|c|c|c|c|c|c|c|c|c|}
\hline & & & & $\log ($ Cond $)$ & 41.806 & 22.509 & 0.345 & 1.857 & 0.106 \\
\hline & & & & $\log (\mathrm{AFDM})^{* *}$ & 28.938 & 8.087 & 0.730 & 3.579 & 0.009 \\
\hline & & & & Mineral & -0.345 & 0.441 & -0.240 & -0.783 & 0.459 \\
\hline Yucatan & 0.895 & 15.99 & 0.023 & (Constant) & 297.547 & 43.943 & & 6.771 & 0.007 \\
\hline & & & & $\log (\mathrm{TP})^{* *}$ & -43.522 & 12.242 & -0.739 & -3.555 & 0.038 \\
\hline & & & & $\log ($ Cond $) * *$ & -51.504 & 8.957 & -1.369 & -5.750 & 0.010 \\
\hline & & & & $\log (\mathrm{AFDM})^{*}$ & -20.744 & 6.915 & -0.387 & -3.000 & 0.058 \\
\hline & & & & Mineral & 0.483 & 0.229 & 0.333 & 2.115 & 0.125 \\
\hline
\end{tabular}


Table 5-3. Mean morphometric data for Encyonema evergladianum specimens from the Everglades, Belize, and Yucatan ( $n$ $=35 /$ site $)$. $\mathrm{SD}=$ standard deviation, $\min =$ minimum, $\max =$ maximum.

\begin{tabular}{|c|c|c|c|c|c|c|c|c|c|c|c|c|c|c|c|c|c|c|c|}
\hline \multirow[b]{2}{*}{ Location } & \multicolumn{3}{|c|}{ Length $(\mu \mathrm{m})$} & \multicolumn{4}{|c|}{ Width $(\mu \mathrm{m})$} & \multicolumn{4}{|c|}{ Striae $/ 10 \mu \mathrm{m}$} & \multicolumn{4}{|c|}{$\mathrm{L}: \mathrm{W}$} & \multicolumn{4}{|c|}{ Curvature $(1 / \mu \mathrm{m})$} \\
\hline & Mean & $\mathrm{SD}$ & Min Max & Mean & SD & Min & Max & Mean & SD & Min & Max & Mean & SD & Min & $\operatorname{Max}$ & Mean & SD & Min & Max \\
\hline Combined & 21.5 & 3.6 & 13.533 .3 & 4.1 & 0.4 & 3.2 & 5.1 & 22.2 & 1.1 & 20.0 & 24.0 & 5.2 & 0.6 & 3.9 & 7.0 & 9.2 & 1.8 & 5.6 & 14.8 \\
\hline Everglades & 23.5 & 3.7 & 16.433 .3 & 4.5 & 0.3 & 3.8 & 5.0 & 21.1 & 0.7 & 20.0 & 22.0 & 5.3 & 0.6 & 3.9 & 6.6 & 9.9 & 2.1 & 6.7 & 14.8 \\
\hline Yucatan & 21.3 & 2.9 & 13.526 .7 & 3.9 & 0.3 & 3.2 & 4.6 & 22.9 & 0.8 & 21.0 & 24.0 & 5.4 & 0.6 & 4.2 & 7.0 & 8.8 & 1.4 & 5.6 & 11.7 \\
\hline
\end{tabular}


Figure 5-1. Box-and-whisker plots for Encyonema evergladianum abundance (A), conductivity (B), periphyton total P (TP) (C), periphyton ash-free dry mass (AFDM) (D), and periphyton mineral content (E) for Belize, Everglades, and Yucatan. Lines in boxes are medians, box ends are quartiles, whiskers are max and min values, circles are outliers, and stars are extreme outliers. Boxes with the same lower case letter are not significantly different $(p \geq 0.05)$.
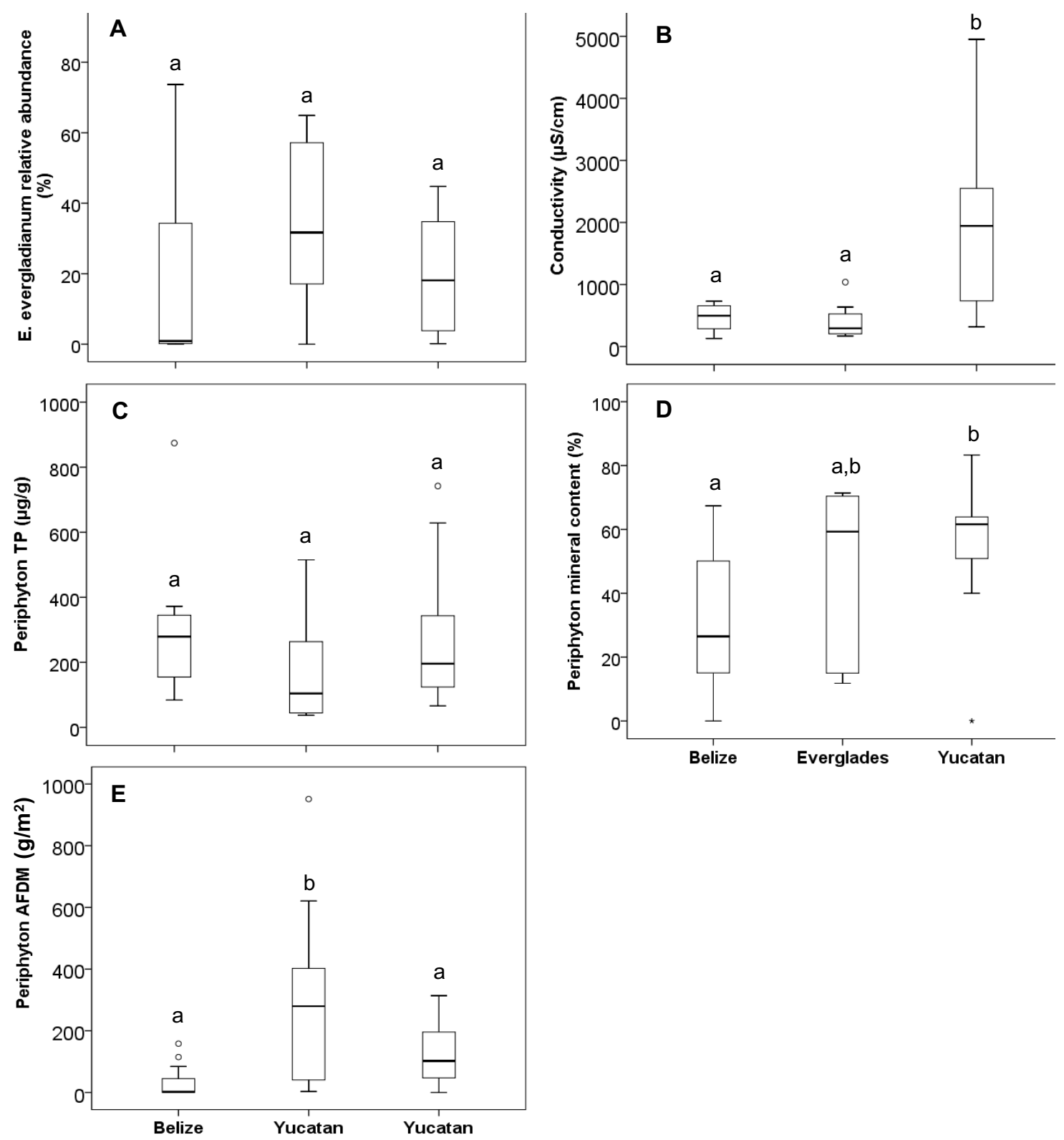
Figure 5-2. Partial regression plots with confidence intervals of significant predictors of Encyonema evergladianum abundance in Belize (AFDM) (A), Everglades (AFDM) (B) Yucatan (conductivity) (C), and the 3 locations combined (AFDM) (D). AFDM = ash-free dry mass.
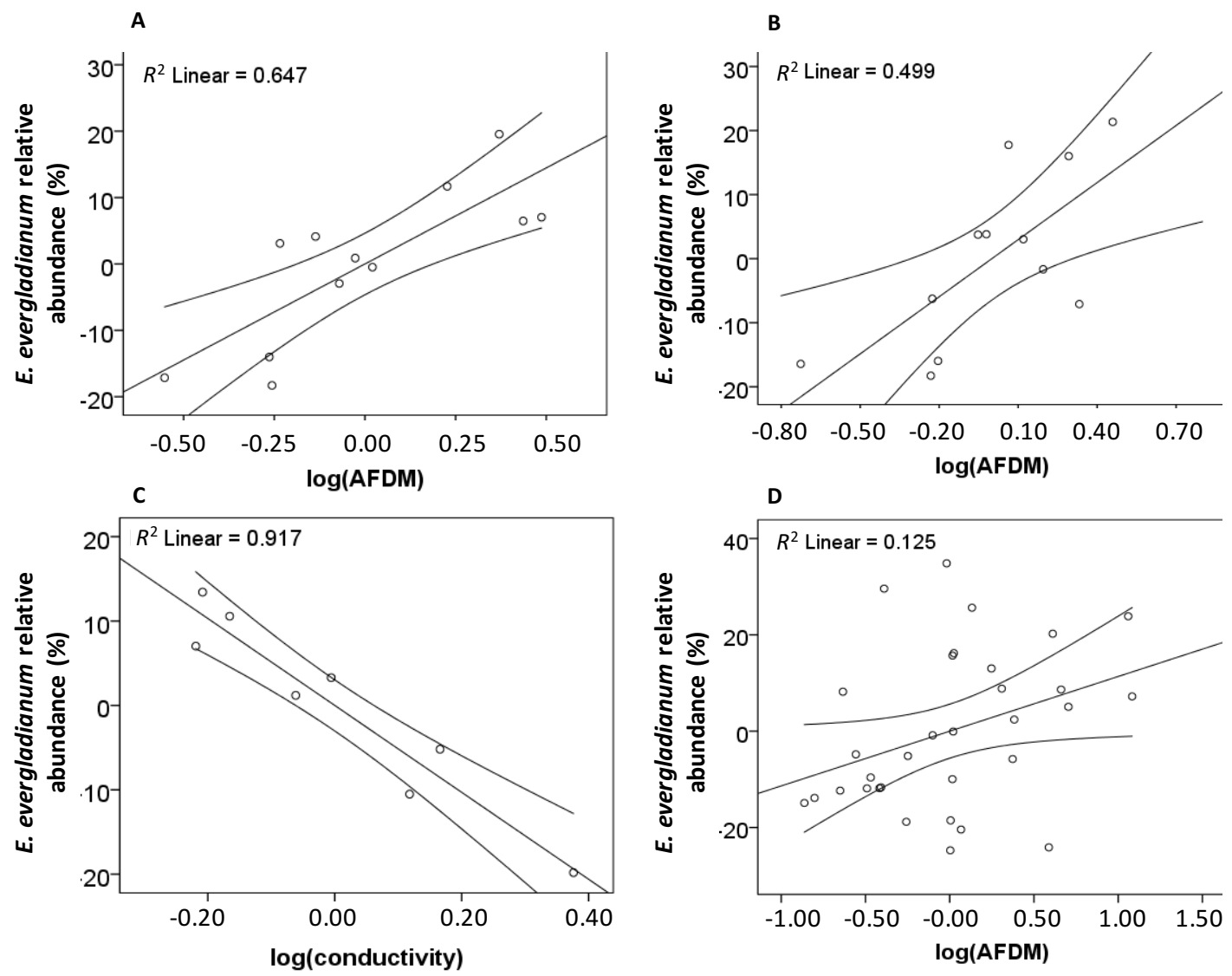
Figure 5-3. Nonmetric multidimensional scaling ordination of morphological data showing specimen groupings by location. $\mathrm{L}: \mathrm{W}=$ length:width ratio.

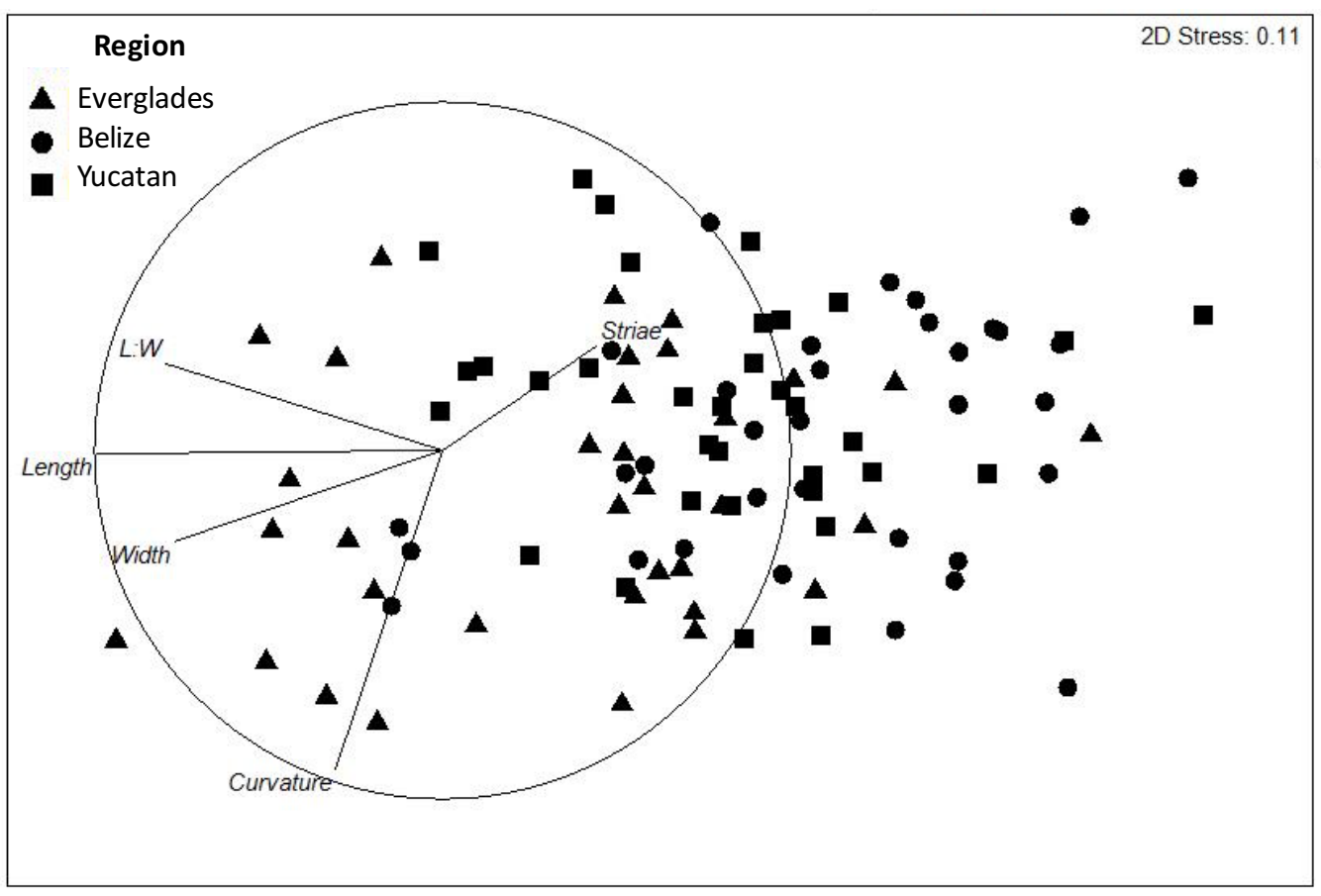


Figure 5-4. Size declinations of Encyonema evergladianum from Belize (A), Everglades (B), and Yucatan (C). Scale bar $=10 \mu \mathrm{m}$.

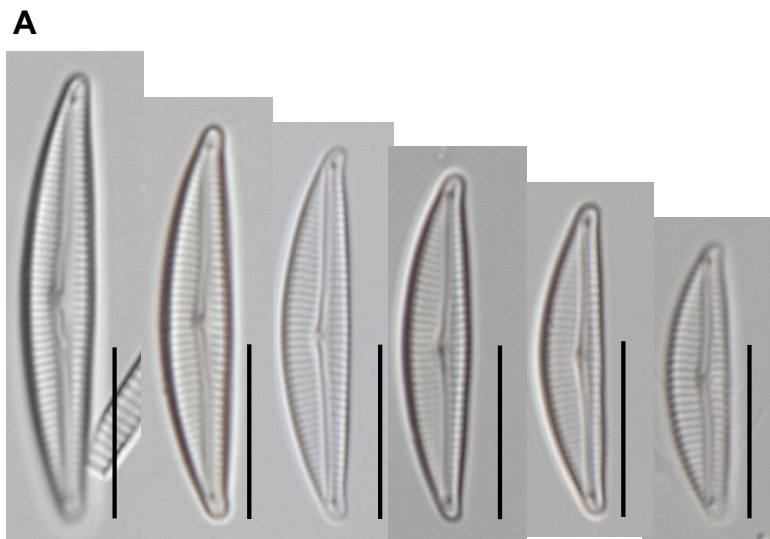

B

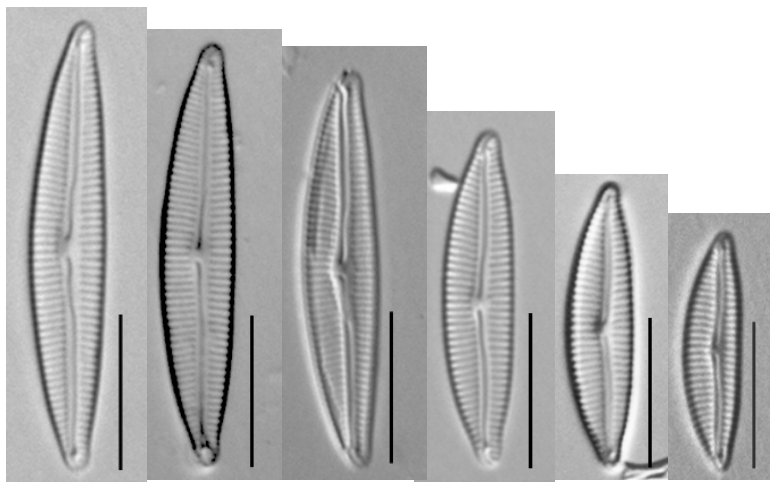

C

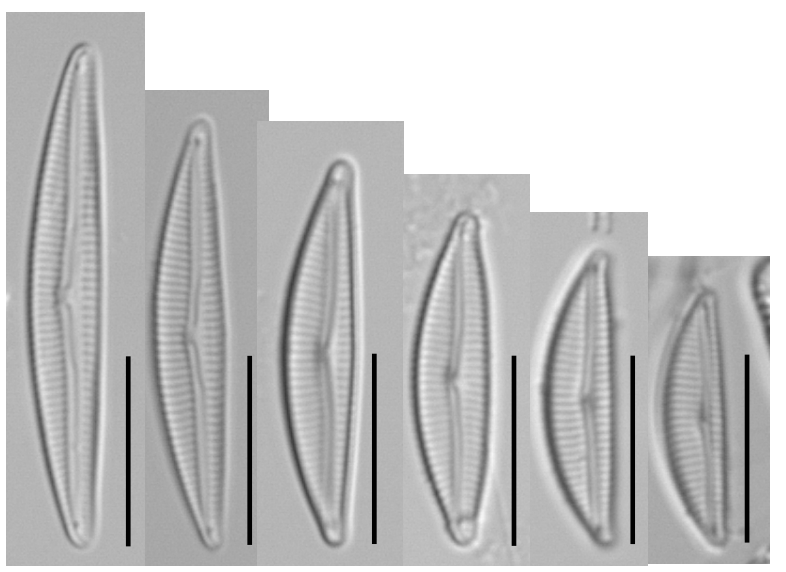


Figure 5-5. Photograph of typical calcareous periphyton mat (A), scanning electron micrograph of the internal mat structure (B), Encyonema evergladianum embedded within the mat matrix $(\mathrm{C})$, and scanning electron micrographs of E. evergladianum (scale bar $=5$ $\mu \mathrm{m})(\mathrm{D})$.

A

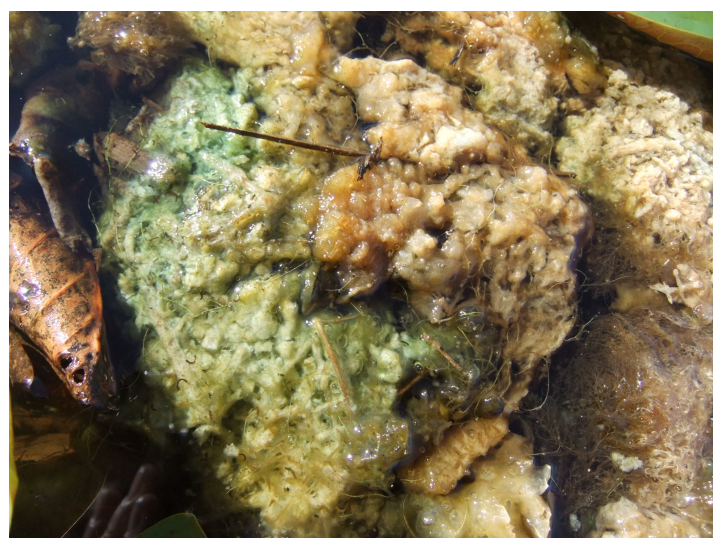

C

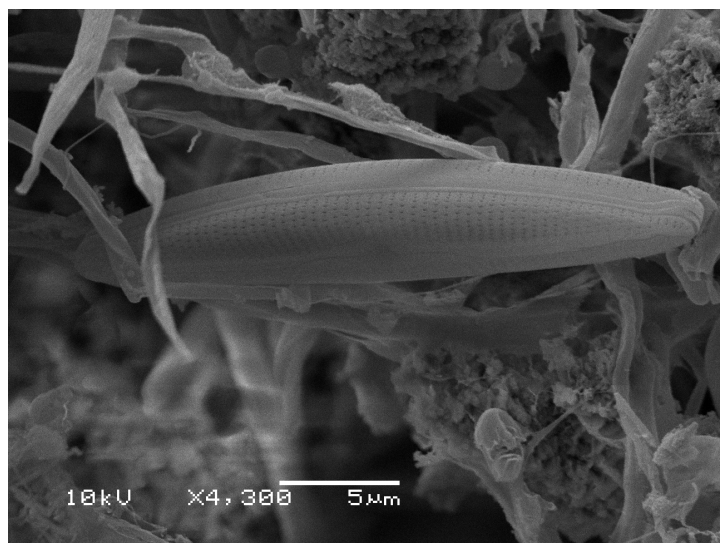

\section{B}

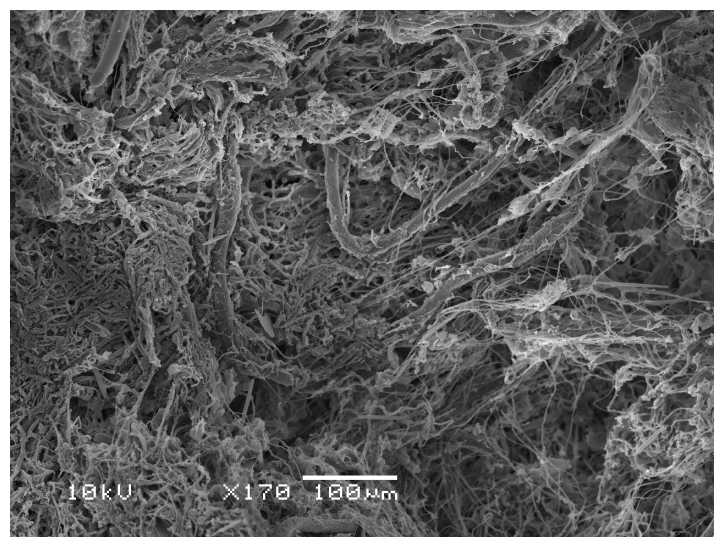

D

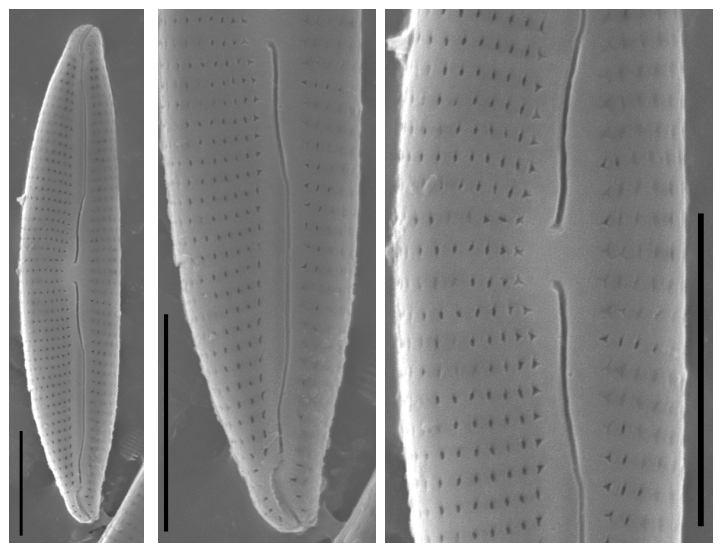




\section{CHAPTER VI}

\section{GENERAL CONCLUSIONS}

Periphyton is considered a primary ecosystem engineer in karstic, freshwater wetlands. However, because these landscapes are typically located along coastlines, saltwater intrusion has the potential to alter the performance, and thus the ecological roles, of these dominant primary producers. The inland movement of marine water transforms the natural salinity and phosphorus gradients of the southern Everglades in ways that affect both micro-scale processes, such as biogeochemical cycling, and landscape patterns of community structure. We demonstrate that the southern Everglades exhibits spatiallystructured gradients of conductivity and $\mathrm{P}$ occurring in both latitudinal and longitudinal directions, and that these drivers are often, but not always, positively correlated. We show that salinity and $\mathrm{P}$ drive periphyton abundance, structure, and taxonomic composition and small-scale changes in these drivers affects periphyton mat integrity and species composition, with consequences that are expected to resonate throughout the food web. The field transect survey component of this research is the first to develop diatom assemblage thresholds, and one of the few to provide taxa-specific thresholds, for conductivity and TP in the southern Everglades. However, this work should be continued and extended to include greater spatial and temporal resolution surveys of diatom flora along salinity and TP gradients throughout the coastal Everglades. This will allow us to harmonize indicator species catalogs and calibrate taxa and assemblage thresholds by region for more accurate assessments and predictions of saltwater intrusion and associated P inputs to different parts of the coastal Everglades. 
Through the experimental components of this research we were able to test the individual and combined effects of salinity and $\mathrm{P}$ on periphyton functional process and diatom composition. The results of the in situ mesocosm experiment demonstrated that simulated monthly pulses of saltwater intrusion into naturally freshwater marshes suppressed periphyton primary productivity, reduced mat TC content, and nutrient uptake. These functional responses to salinity increases of only 1 ppt above ambient surface water levels were accompanied by significant shifts in periphytic diatom assemblages, underscoring the effectiveness of diatoms as fast and sensitive indicators of environmental variability. Brackish water periphyton differs in physical structure and species composition than the cohesive, calcareous mats found in freshwater marshes and was more resilient to the monthly pulses of elevated salinity. Brackish water mats responded to a $2 \mathrm{ppt}$ increase in surface water salinity with suppressed productivity immediately after the first salinity dosing, but were unaffected thereafter; and did not exhibit significant decreases in overall TC, TN, or TP content. Despite the metabolic and nutritional resilience of brackish water periphyton mats to saltwater exposure, the periphytic-diatom assemblages responded to the saltwater treatment with altered species composition.

The ex situ mesocosm experiment supported our findings on periphyton responses to elevated salinity and provided additional information on the cumulative effects of salinity and $\mathrm{P}$ to help us better understand consequences of saltwater intrusion on periphyton. We observed patterns of reduced productivity, TC, and nutrient uptake in freshwater periphyton exposed to saltwater. The addition of $\mathrm{P}$ to freshwater mats tended to increase chlorophyll- $a$ and nutrient content while having no significant effect on productivity or total carbon content. Similar patterns were observed for salt-treated mats 
with added phosphorus, although these mats had significantly higher gross primary productivity and net ecosystem productivity compared to mats treated only with salinity. We found significant dissimilarity in diatom composition between fresh- and saltwater treated mats. Freshwater mats treated with P did not exhibit significantly different diatom assemblages compared to freshwater mats; however, two diatom species were recognized as significant indicators of enriched freshwater conditions. The addition of P to salt-treated mats caused significant taxonomic divergence and indicator taxa of enriched saltwater conditions were also identified.

Our results provide valuable information on the functional and compositional responses of periphyton to individual and effects of increased salinity and P that can help us predict changes caused by saltwater intrusion, but still leave many questions unanswered due to the complex nature of periphyton mats. Periphyton is essentially a micro-ecosystem with internal biogeochemical cycles and species interactions that are strongly influenced by external ecosystem dynamics. Despite this complexity, diatom assemblages provide us with information regarding both external (i.e., landscape scale changes in abiotic drivers) and internal (i.e., periphyton physical structure) environmental conditions. Diatom assemblages not only respond to changes in abiotic drivers, such as salinity and $\mathrm{P}$, but to the structure of the periphyton mats so that the loss of calcareous mats will not support the same diatom assemblages. Although some diatom species contribute to mat formation and cohesion through the production of attachment structure and the excretion of extracellular polymeric substances, evidence points to many periphytic diatoms simply relying on calcareous periphyton mats as a microhabitat without necessarily contributing to its cohesion (Mazzei and Gaiser 2016). For example, we determined the the relative 
abundance of the regional E. evergladianum population from the Caribbean Basin was most strongly driven by calcareous periphyton biomass rather than directly by salinity and P conditions. However, subpopulations from the 3 wetlands we examined did not respond consistently to the environmental drivers considered in our study suggesting that the application of this species as an indicator at the regional scale may result in overlooking or misinterpreting local change unless responses are calibrated based on conditions within individual wetlands. A better understanding of the direct effects of salinity and $\mathrm{P}$ on diatom composition versus possible indirect effects of calcareous periphyton microhabitat loss or structural changes in response to these drivers is still needed. Furthermore, we need more experimental studies to understand the exact mechanism behind periphyton disintegration with $\mathrm{P}$ enrichment. Future, studies need to focus on a more complete survey of changing autotrophic species composition in response to both salinity and P to effectively capture the multifaceted responses of periphyton to saltwater intrusion. This project represents a stepping stone in the effort to extend the use of predictive diatom metrics to the southern Everglades. There they can be used to assess and predict the movement of ecological boundaries driven by saltwater intrusion and changing freshwater inflows, in an area of the ecosystem where this balance is most pronounced. 


\section{APPENDICES}

Table 2-1. Mean, standard deviation, minimum, and maximum values of relevant environmental variables for each transect during the four sampling events.

\begin{tabular}{|c|c|c|c|c|c|c|c|c|c|c|c|c|c|c|c|c|c|}
\hline \multirow[b]{2}{*}{ Transect } & \multirow[b]{2}{*}{ Season } & \multicolumn{4}{|c|}{ Water Depth (cm) } & \multicolumn{4}{|c|}{ Soil Depth (cm) } & \multicolumn{4}{|c|}{$\mathrm{SW}$ conductivity $\left(\mathrm{mS} \mathrm{cm}^{-1}\right)$} & \multicolumn{4}{|c|}{ PW Conductivity $\left(\mathrm{mS} \mathrm{cm}^{-1}\right)$} \\
\hline & & Mean & STDEV & Min & Max & Mean & STDEV & Min & Max & Mean & STDEV & Min & Max & Mean & STDEV & Min & Max \\
\hline \multirow[t]{4}{*}{$\mathrm{T} 1$} & Dry 2014 & 0.0 & 0.0 & 0.0 & 0.0 & 46.1 & 36.3 & 6.0 & $>100$ & & & & & 3.2 & 2.7 & 0.5 & 7.3 \\
\hline & Dry 2015 & 0.9 & 3.2 & 0.0 & 12.0 & 38.8 & 38.2 & 0.5 & $>100$ & 9.8 & 5.5 & 5.9 & 13.7 & 10.2 & 11.9 & 2.7 & 30.3 \\
\hline & Wet 2014 & 18.3 & 7.6 & 4.0 & 30.0 & 41.7 & 36.5 & 6.0 & $>100$ & 1.1 & 1.4 & 0.3 & 4.2 & 7.3 & 0.3 & 7.1 & 7.5 \\
\hline & Wet 2015 & 29.8 & 10.4 & 10.5 & 46.3 & 42.9 & 38.6 & 1.0 & $>100$ & 1.3 & 2.3 & 0.2 & 7.3 & 3.2 & 4.2 & 0.2 & 11.2 \\
\hline \multirow[t]{4}{*}{$\mathrm{T} 2$} & Dry 2014 & 3.2 & 7.2 & 0.0 & 16.0 & 51.0 & 33.3 & 20.0 & $>100$ & 0.6 & & 0.6 & 0.6 & 2.8 & 3.7 & 0.9 & 9.3 \\
\hline & Dry 2015 & 6.8 & 10.0 & 0.0 & 22.0 & 51.0 & 37.3 & 17.0 & $>100$ & 1.0 & 0.2 & 0.9 & 1.3 & 3.8 & 5.1 & 1.3 & 12.8 \\
\hline & Wet 2014 & 32.5 & 5.8 & 27.0 & 38.0 & 46.3 & 17.9 & 34.0 & 72.0 & 0.6 & 0.1 & 0.5 & 0.8 & 1.4 & 0.3 & 1.1 & 1.9 \\
\hline & Wet 2015 & 42.6 & 9.2 & 32.0 & 55.0 & 53.0 & 32.4 & 22.0 & $>100$ & 0.9 & 0.3 & 0.6 & 1.4 & 3.9 & 4.8 & 1.6 & 12.5 \\
\hline \multirow[t]{4}{*}{$\mathrm{T} 3$} & Dry 2014 & 10.0 & 7.4 & 0.0 & 17.0 & 83.8 & 19.5 & 64.0 & $>100$ & 12.5 & 4.4 & 7.7 & 16.2 & 9.4 & 6.6 & 1.7 & 17.1 \\
\hline & Dry 2015 & 5.8 & 11.5 & 0.0 & 23.0 & 88.0 & 14.7 & 69.0 & $>100$ & 14.5 & 6.4 & 10.0 & 19.0 & 11.3 & 6.2 & 2.0 & 15.0 \\
\hline & Wet 2014 & 32.8 & 8.9 & 22.0 & 41.0 & 78.0 & 15.5 & 68.0 & $>100$ & 1.7 & 1.5 & 0.3 & 3.5 & 11.7 & 6.7 & 1.7 & 16.1 \\
\hline & Wet 2015 & 26.7 & 5.1 & 21.0 & 31.7 & 90.0 & 14.9 & 69.0 & $>100$ & 4.0 & 3.5 & 0.3 & 8.4 & 22.6 & 15.0 & 1.8 & 34.2 \\
\hline \multirow[t]{4}{*}{$\mathrm{T} 4$} & Dry 2014 & 8.8 & 5.4 & 1.2 & 14.0 & 83.3 & 19.3 & 56.0 & $>100$ & 15.8 & 8.2 & 7.3 & 27.1 & 13.5 & 7.9 & 7.9 & 24.9 \\
\hline & Dry 2015 & 10.3 & 6.4 & 1.0 & 15.0 & 88.0 & 10.2 & 76.0 & $>100$ & 20.4 & 15.8 & 4.1 & 41.5 & 16.3 & 5.5 & 9.0 & 22.3 \\
\hline & Wet 2014 & 28.3 & 0.5 & 28.0 & 29.0 & 83.0 & 20.8 & 63.0 & $>100$ & 1.0 & 0.4 & 0.4 & 1.4 & 13.4 & 5.1 & 6.0 & 17.7 \\
\hline & Wet 2015 & 20.3 & 8.5 & 11.0 & 31.7 & 91.8 & 8.7 & 80.0 & $>100$ & 3.1 & 2.4 & 0.8 & 5.2 & 27.6 & 9.1 & 16.0 & 37.5 \\
\hline \multirow[t]{4}{*}{ T5 } & Dry 2014 & 4.7 & 8.1 & 0.0 & 14.0 & 77.7 & 9.7 & 67.0 & 86.0 & 36.3 & & 36.3 & 36.3 & 16.8 & 9.5 & 5.9 & 23.3 \\
\hline & Dry 2015 & 14.0 & 7.8 & 9.0 & 23.0 & 84.3 & 8.7 & 77.0 & 94.0 & 28.6 & 20.5 & 6.4 & 46.9 & 18.8 & 8.0 & 9.6 & 24.6 \\
\hline & Wet 2014 & 28.7 & 3.8 & 26.0 & 33.0 & 70.7 & 6.5 & 64.0 & 77.0 & 0.9 & 0.3 & 0.6 & 1.2 & 10.7 & 3.7 & 7.5 & 14.7 \\
\hline & Wet 2015 & 25.1 & 13.7 & 13.7 & 40.3 & 80.0 & 36.4 & 38.0 & $>100$ & 1.7 & 0.9 & 0.7 & 2.6 & 23.7 & 8.8 & 15.4 & 33.0 \\
\hline \multirow[t]{4}{*}{ T6 } & Dry 2014 & 5.0 & 7.8 & 0.0 & 14.0 & $>100$ & 0.0 & $>100$ & $>100$ & 55.2 & 0.0 & 55.2 & 55.2 & 39.6 & 19.6 & 17.1 & 53.0 \\
\hline & Dry 2015 & 14.3 & 15.0 & 0.0 & 30.0 & $>100$ & 0.0 & $>100$ & $>100$ & 50.3 & 10.3 & 43.0 & 57.6 & 31.6 & 26.4 & 1.3 & 50.0 \\
\hline & Wet 2014 & 27.3 & 12.0 & 15.0 & 39.0 & $>100$ & 0.0 & $>100$ & $>100$ & 4.2 & 5.2 & 0.6 & 10.1 & 15.2 & 11.8 & 1.6 & 22.8 \\
\hline & Wet 2015 & 29.8 & 3.8 & 26.7 & 34.0 & $>100$ & 0.0 & $>100$ & $>100$ & 6.6 & 9.1 & 0.6 & 17.1 & 20.7 & 18.1 & 1.6 & 37.6 \\
\hline \multirow[t]{4}{*}{$\mathrm{T} 7$} & Dry 2014 & 6.3 & 5.4 & 0.0 & 13.0 & 84.5 & 33.0 & 35.0 & $>100$ & 53.1 & 5.5 & 47.1 & 58.0 & 45.9 & 14.6 & 26.6 & 59.3 \\
\hline & Dry 2015 & 15.5 & 12.0 & 0.0 & 29.0 & 87.5 & 27.0 & 47.0 & $>100$ & 8.7 & 1.5 & 7.0 & 10.0 & 36.0 & 13.7 & 19.0 & 49.0 \\
\hline & Wet 2014 & 22.0 & 3.7 & 18.0 & 26.0 & 82.5 & 37.0 & 27.0 & $>100$ & 7.1 & 5.0 & 1.7 & 13.8 & 26.6 & 8.6 & 14.0 & 32.9 \\
\hline & Wet 2015 & 46.7 & 17.3 & 27.7 & 67.7 & 94.0 & 14.0 & 73.0 & $>100$ & 5.2 & 3.4 & 1.1 & 9.2 & 24.7 & 9.4 & 14.2 & 35.1 \\
\hline
\end{tabular}


Table 2-2. Mean, standard deviation, minimum, and maximum values of relevant periphyton mat variables for each transect during the four sampling events.

\begin{tabular}{|c|c|c|c|c|c|c|c|c|c|c|c|c|c|c|c|c|c|}
\hline \multirow[b]{2}{*}{ Transect } & \multirow[b]{2}{*}{ Season } & \multicolumn{4}{|c|}{ Mat TP $\left(\mu g^{-1}\right)$} & \multicolumn{4}{|c|}{$\operatorname{AFDW}\left(\mathrm{g} \mathrm{m}^{-2}\right)$} & \multicolumn{4}{|c|}{ Mineral content $(\%)$} & \multicolumn{4}{|c|}{ Chla $\left(\mu \mathrm{g} \mathrm{g}^{-1}\right)$} \\
\hline & & Mean & STDEV & Min & Max & Mean & STDEV & Min & Max & Mean & STDEV & Min & Max & Mean & STDEV & Min & Max \\
\hline \multirow[t]{4}{*}{$\mathrm{T} 1$} & Dry 2014 & 180.4 & 150.6 & 37.3 & 456.0 & 553.4 & 550.1 & 22.4 & 1647.7 & 53.2 & 23.9 & 14.8 & 76.4 & 252.3 & 190.5 & 34.9 & 592.3 \\
\hline & Dry 2015 & 305.2 & 308.2 & 45.7 & 945.4 & 699.0 & 741.8 & 19.4 & 2161.6 & 58.7 & 20.9 & 17.3 & 79.4 & 273.4 & 269.3 & 39.2 & 920.7 \\
\hline & Wet 2014 & 179.7 & 208.2 & 25.5 & 686.7 & 145.0 & 73.6 & 36.3 & 277.6 & 53.1 & 23.0 & 15.3 & 72.5 & 462.6 & 433.6 & 109.1 & 1552.6 \\
\hline & Wet 2015 & 235.7 & 217.2 & 52.3 & 573.2 & 190.7 & 169.3 & 11.6 & 630.1 & 47.1 & 25.5 & 13.1 & 75.0 & 592.1 & 623.1 & 81.6 & 1935.8 \\
\hline \multirow[t]{3}{*}{$\mathrm{T} 2$} & Dry 2014 & 106.5 & 82.9 & 40.8 & 215.5 & 234.3 & 169.5 & 22.2 & 454.5 & 51.4 & 28.8 & 19.1 & 73.6 & 226.0 & 182.7 & 99.9 & 529.4 \\
\hline & Dry 2015 & 182.7 & 151.9 & 59.5 & 419.5 & 328.1 & 425.4 & 23.0 & 1069.5 & 48.2 & 33.7 & 5.7 & 73.9 & 185.7 & 111.0 & 87.5 & 328.5 \\
\hline & Wet 2015 & 185.6 & 156.0 & 68.9 & 367.7 & 136.3 & 107.7 & 28.8 & 291.0 & 46.1 & 28.0 & 15.1 & 67.6 & 487.6 & 412.7 & 185.7 & 1082.1 \\
\hline \multirow[t]{4}{*}{$\mathrm{T} 3$} & Dry 2014 & 105.3 & 95.8 & 30.7 & 246.0 & 427.4 & 604.1 & 85.7 & 1332.6 & 57.8 & 27.5 & 17.0 & 74.5 & 141.8 & 108.8 & 30.2 & 291.3 \\
\hline & Dry 2015 & 216.1 & 97.2 & 78.5 & 307.0 & 166.4 & 186.8 & 17.0 & 430.2 & 61.3 & 14.0 & 48.0 & 74.2 & 277.1 & 130.8 & 121.7 & 420.7 \\
\hline & Wet 2014 & 154.8 & 161.0 & 41.7 & 392.3 & 89.9 & 125.2 & 7.6 & 275.9 & 51.3 & 25.2 & 15.1 & 73.9 & 489.9 & 404.0 & 118.2 & 1063.2 \\
\hline & Wet 2015 & 246.8 & 106.4 & 165.7 & 367.3 & 124.9 & 60.9 & 61.7 & 183.3 & 52.9 & 26.3 & 22.9 & 72.2 & 444.5 & 303.4 & 127.3 & 731.9 \\
\hline \multirow[t]{3}{*}{$\mathrm{T} 4$} & Dry 2014 & 54.7 & 19.0 & 37.4 & 81.8 & 197.2 & 48.0 & 125.4 & 225.2 & 74.9 & 6.5 & 65.8 & 81.2 & 195.0 & 55.8 & 120.0 & 248.6 \\
\hline & Dry 2015 & 144.7 & 91.4 & 82.5 & 279.3 & 136.6 & 88.4 & 29.8 & 231.8 & 70.2 & 7.7 & 60.8 & 76.7 & 153.9 & 52.3 & 119.1 & 231.8 \\
\hline & Wet 2014 & 49.7 & 8.6 & 40.9 & 61.4 & 97.3 & 55.7 & 21.1 & 154.2 & 71.5 & 8.9 & 60.7 & 80.7 & 267.3 & 80.4 & 214.1 & 386.8 \\
\hline \multirow[t]{4}{*}{$\mathrm{T} 5$} & Dry 2014 & 43.0 & 9.1 & 32.8 & 50.4 & 234.4 & 191.2 & 13.8 & 351.9 & 77.3 & 11.2 & 65.3 & 87.4 & 84.0 & 18.0 & 70.7 & 104.4 \\
\hline & Dry 2015 & 69.0 & 6.2 & 65.0 & 76.2 & 131.5 & 75.9 & 84.9 & 219.1 & 83.2 & 3.2 & 80.4 & 86.7 & 89.6 & 26.3 & 62.3 & 114.8 \\
\hline & Wet 2014 & 44.0 & 7.3 & 35.9 & 50.0 & 166.6 & 128.7 & 27.3 & 281.1 & 71.0 & 8.0 & 61.9 & 76.6 & 199.1 & 14.8 & 183.8 & 213.3 \\
\hline & Wet 2015 & 77.7 & 30.9 & 53.8 & 112.5 & 70.0 & 76.3 & 24.5 & 158.1 & 71.8 & 9.4 & 65.1 & 82.6 & 164.5 & 87.2 & 63.9 & 218.9 \\
\hline \multirow[t]{4}{*}{ T6 } & Dry 2014 & 47.3 & 11.1 & 37.9 & 59.5 & 358.7 & 486.2 & 37.4 & 918.0 & 81.8 & 5.9 & 75.2 & 86.6 & 46.8 & 23.3 & 20.2 & 63.1 \\
\hline & Dry 2015 & 109.6 & 41.5 & 68.0 & 150.9 & 188.9 & 226.3 & 55.1 & 450.2 & 81.7 & 4.9 & 76.4 & 86.0 & 79.1 & 19.3 & 57.2 & 93.1 \\
\hline & Wet 2014 & 65.4 & 18.1 & 44.5 & 76.6 & 71.2 & 78.0 & 25.2 & 161.3 & 69.7 & 2.0 & 67.3 & 71.1 & 230.6 & 77.9 & 153.5 & 309.3 \\
\hline & Wet 2015 & 128.1 & 72.9 & 76.5 & 179.6 & 151.5 & 188.4 & 18.2 & 284.7 & 69.2 & 4.0 & 66.3 & 72.0 & 510.7 & 424.2 & 210.7 & 810.6 \\
\hline \multirow[t]{4}{*}{$\mathrm{T} 7$} & Dry 2014 & 48.5 & 28.8 & 21.8 & 86.5 & 279.0 & 437.8 & 52.1 & 935.6 & 79.9 & 4.5 & 75.6 & 83.9 & 62.1 & 50.4 & 20.8 & 135.5 \\
\hline & Dry 2015 & 69.2 & 15.6 & 55.1 & 84.2 & 522.4 & 720.7 & 78.8 & 1595.5 & 57.3 & 16.0 & 46.5 & 81.1 & 64.9 & 18.5 & 48.2 & 85.8 \\
\hline & Wet 2014 & 44.1 & 5.8 & 37.8 & 50.9 & 90.9 & 105.5 & 33.4 & 249.1 & 73.3 & 4.6 & 69.3 & 78.5 & 164.2 & 49.9 & 118.1 & 221.0 \\
\hline & Wet 2015 & 73.8 & 16.6 & 58.1 & 95.1 & 101.1 & 151.7 & 22.6 & 328.6 & 76.6 & 5.1 & 71.3 & 82.9 & 109.5 & 57.8 & 48.3 & 187.8 \\
\hline
\end{tabular}


Figure 2-1. Indicator species plates for pure and reliable indicator taxa of $\mathrm{PW}$ conductivity (A) and periphyton TP (B) showing declining (a) and increasing (b) species for each driver. Image numbers correspond to species number in Tables 1 and 2.

Aa.

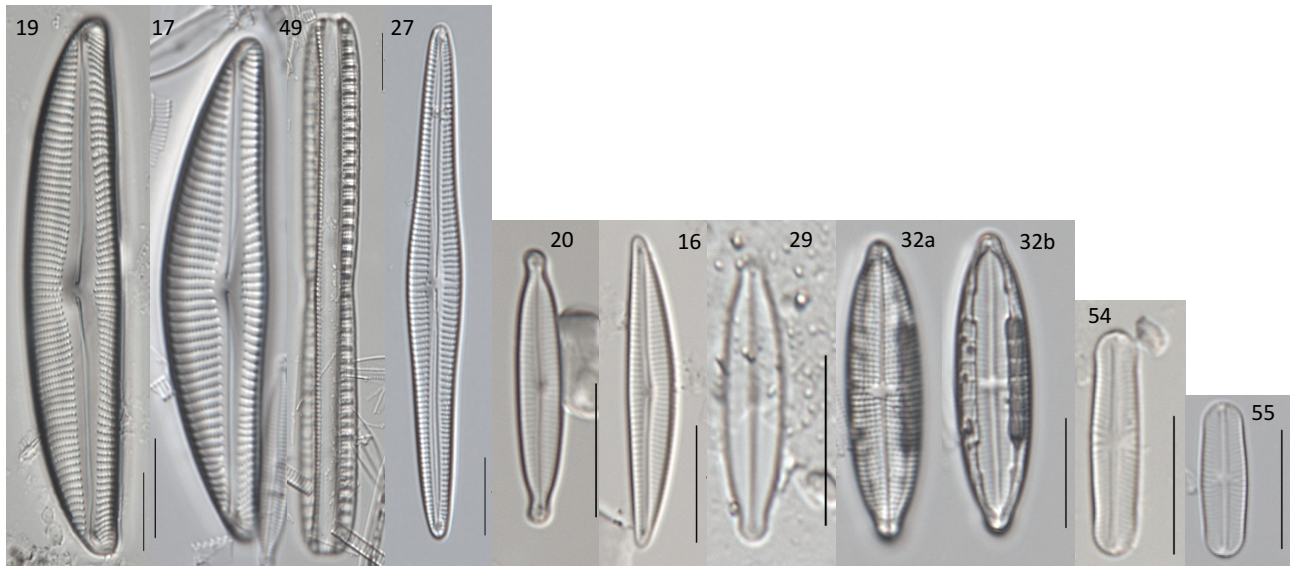

Ab.

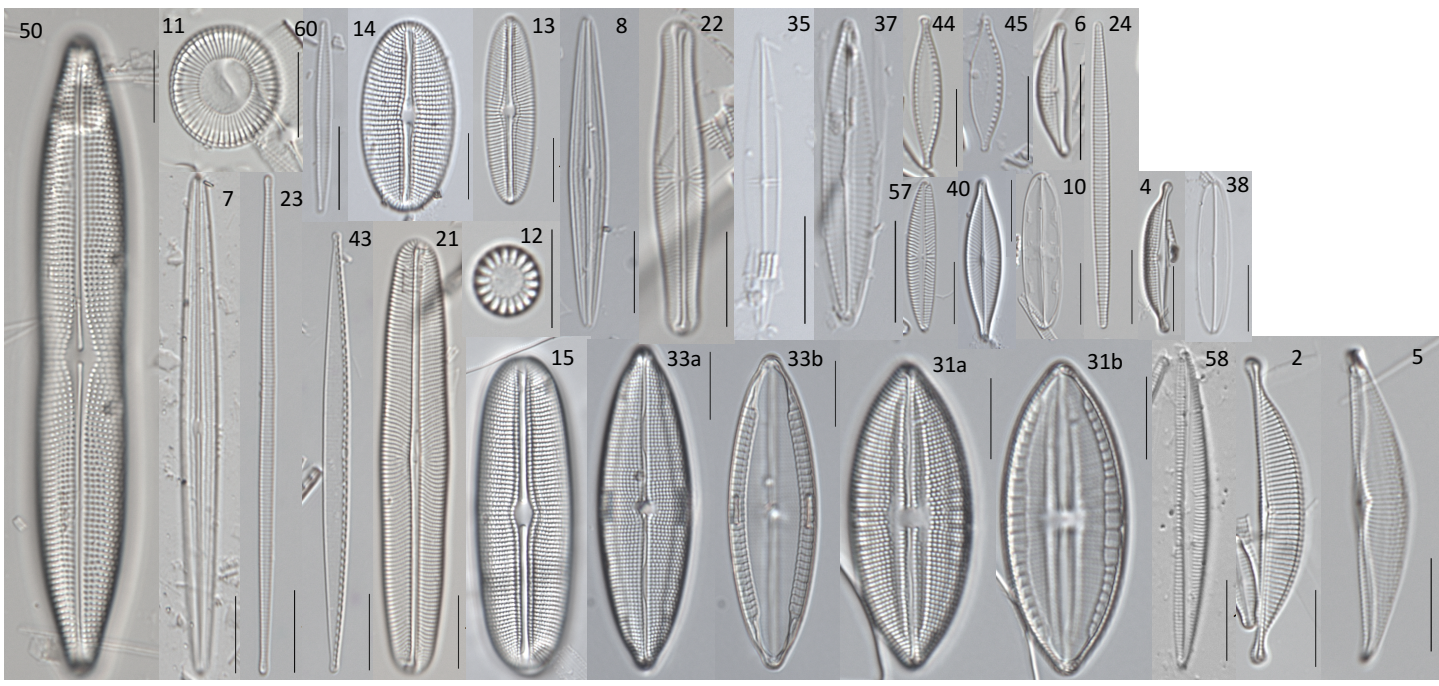


Ba.

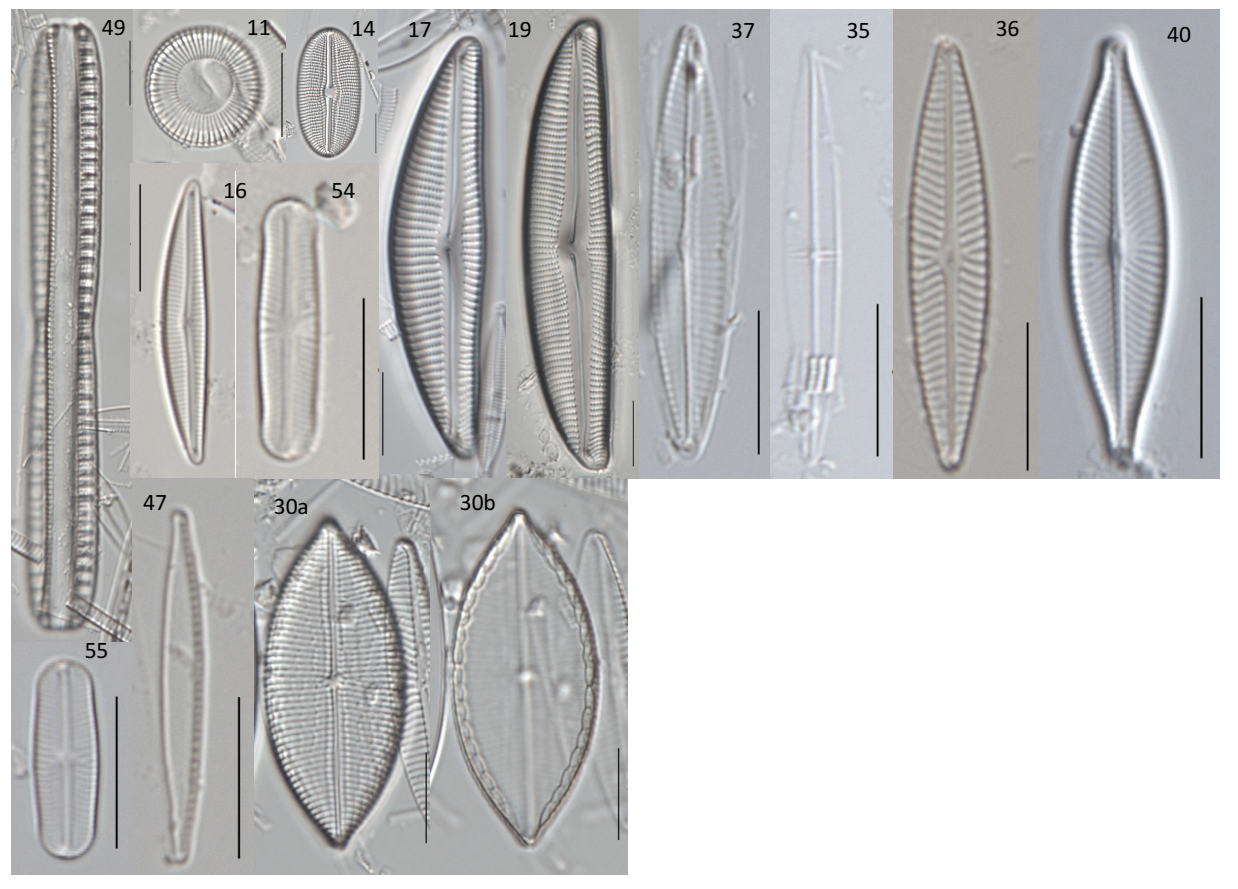

Bb.

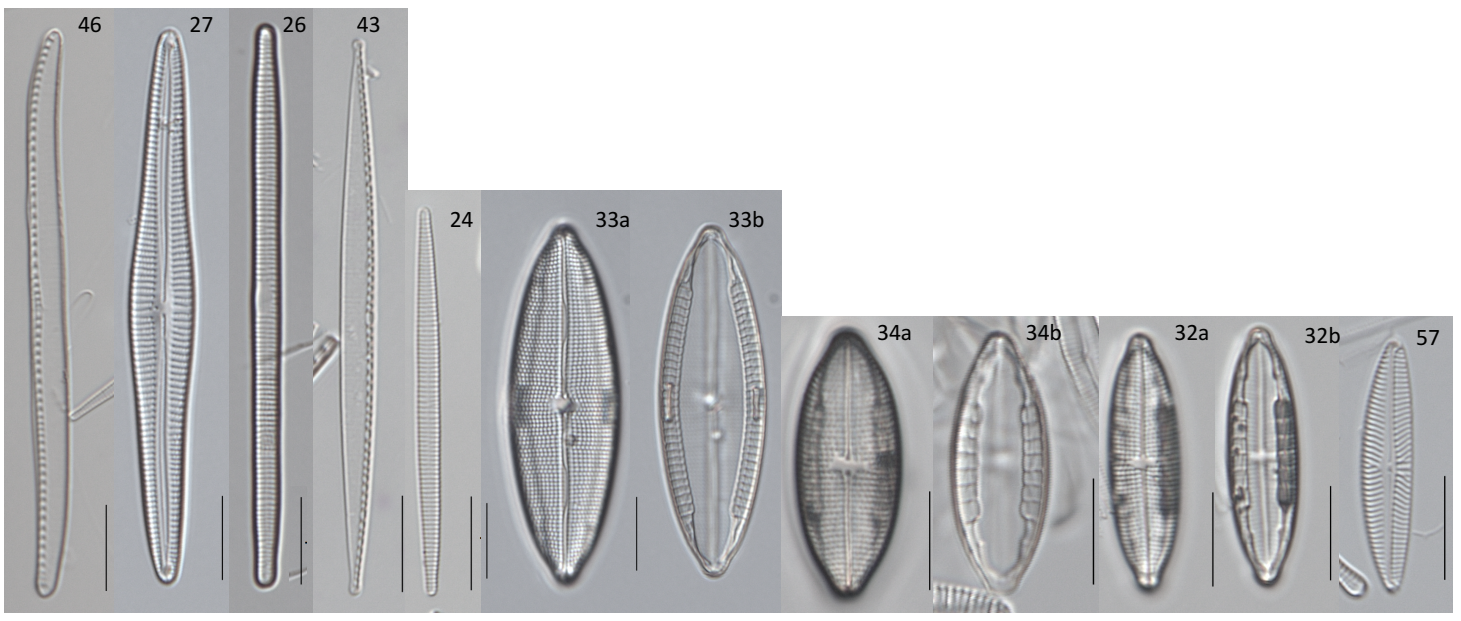


VITA

\section{VIVIANA MAZZEI}

December $2^{\text {nd }}, 1983$

$2002-2009$

$2010-2013$

$2013-2018$

$2013-2015$

$2016-2017$
Born, Miami, Florida, USA

Bachelor of Science, Department of Biological Sciences Florida International University

Miami, FL., USA

Master of Science, Coastal Science

University of Southern Mississippi

Gulf Coast Research Laboratory

Certificate in Geographic Information Technology

University of Southern Mississippi

Department of Geography

Doctoral Candidate, Department of Biological Sciences

Florida International University

Miami, FL., USA

Teaching Assistant, Department of Biological Sciences

Florida International University

Miami, FL., USA

Florida Coastal Everglades Long Term Ecological

Research Program, Student Executive Board

Vice-president

\section{$\underline{\text { PUBLICATIONS AND PRESENTATIONS }}$}

Mazzei, V. and Gaiser, E., 2018. Diatoms as tools for inferring ecotone boundaries in a coastal freshwater wetland threatened by saltwater intrusion. Ecological Indicators 88:190-204

Mazzei, V. and Gaiser, E., 2017. Scale and spatial consistency of specialization in an endemic and abundant freshwater diatom from the Caribbean Basin. Freshwater Science 36:542554.

Mazzei, V. and Biber, P., 2015. Autotrophic net productivity patterns at four artificial reef sites in the Mississippi Sound. Hydrobiologia 749: 135-154. 
Mazzei, V. 2014. Encyonema evergladianum. In Diatoms of the United States. http://westerndiatoms.colorado.edu/taxa/species/encyonema_evergladianum

Collado-Vides, L., Mazzei, V., Thyberg, T., Lirman, D. 2011. Spatio-temporal patterns and nutrient status of macroalgae in a heavily managed region of Biscayne Bay, Florida, USA. Botanica Marina 54:377-390.

Mazzei, V., Gaiser, E., Kominoski, J., Wilson, B., Servais, S., Troxler, T. In review., Functional and compositional responses of periphyton mats to simulated pulses of saltwater intrusion in a fresh and brackish water marsh. Estuaries and Coasts.

Drivers and spatial consistency of specialization in a dominant, mat-dwelling diatom, Encyonema evergladianum, from three freshwater wetlands in the Caribbean Basin $24^{\text {th }}$ North American Diatom Symposium, Put-In-Bay, OH, USA, September 2017 V. Mazzei and E. Gaiser

Response of the dominant diatom E. evergladianum to environmental changes associated with sea level rise in the Caribbean Basin Society of Wetland Scientists, San Juan, Puerto Rico, June 2017 V. Mazzei and E. Gaiser

Functional and compositional responses of periphyton mats to simulated saltwater intrusion in the southern Everglades Greater Everglades Ecosystem Restoration, Coral Springs, FL, USA, April 2017 V. Mazzei, E. Gaiser, J.S. Kominoski, B.J. Wilson, S. Servais, T. Troxler

Experimental saltwater intrusion decreases periphyton production and carbon content in a subtropical freshwater wetland $101^{\text {st }}$ Ecological Society of America, Fort Lauderdale, FL, USA, August 2016

Florida Coastal Everglades All Scientist Meeting, Miami, FL, US, May 2016 V. Mazzei, E. Gaiser, J.S. Kominoski, B.J. Wilson, S. Servais, T. Troxler

Changes in ecosystem carbon responses to saltwater exposure: implications of sea level rise in the Florida Coastal Everglades Florida Coastal Everglades All Scientist Meeting, Miami, FL, USA, May 2016 V. Mazzei, S. Charles, S. Servais, B. Wilson

Response of the diatom Encyonema evergladianum to environmental changes associated with sea level rise in the Caribbean Basin $100^{\text {th }}$ Ecological Society of America, Baltimore, MD, USA, August 2015

Greater Everglades Ecosystem Restoration, Coral Springs, FL, USA, April 2015

V. Mazzei and E. Gaiser 